QA: QA

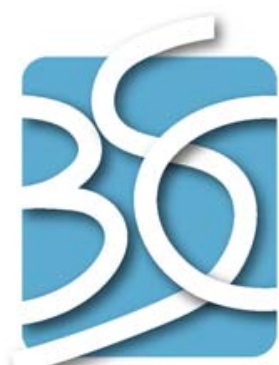

ANL-WIS-PA-000002 REV 05

August 2005

\title{
Engineered Barrier System Features, Events, and Processes
}

NOTICE OF OPEN CHANGE DOCUMENTS - THIS DOCUMENT IS IMPACTED BY THE LISTED CHANGE DOCUMENTS AND CANNOT BE USED WITHOUT THEM.

1) ACN-001, DATED 08/31/2005

Prepared for:

U.S. Department of Energy

Office of Civilian Radioactive Waste Management

Office of Repository Development

1551 Hillshire Drive

Las Vegas, Nevada 89134-6321

Prepared by:

Bechtel SAIC Company, LLC

1180 Town Center Drive

Las Vegas, Nevada 89144

Under Contract Number

DE-AC28-01RW12101 


\section{DISCLAIMER}

This report was prepared as an account of work sponsored by an agency of the United States Government. Neither the United States Government nor any agency thereof, nor any of their employees, nor any of their contractors, subcontractors or their employees, makes any warranty, express or implied, or assumes any legal liability or responsibility for the accuracy, completeness, or any third party's use or the results of such use of any information, apparatus, product, or process disclosed, or represents that its use would not infringe privately owned rights. Reference herein to any specific commercial product, process, or service by trade name, trademark, manufacturer, or otherwise, does not necessarily constitute or imply its endorsement, recommendation, or favoring by the United States Government or any agency thereof or its contractors or subcontractors. The views and opinions of authors expressed herein do not necessarily state or reflect those of the United States Government or any agency thereof. 
QA: QA

Engineered Barrier System Features, Events, and Processes ANL-WIS-PA-000002 REV 05

August 2005 
\begin{tabular}{c|c} 
BSC & $\begin{array}{c}\text { Scientific Analysis Signature Page/ } \\
\text { Change History }\end{array}$
\end{tabular}

Complete only applicable items.
Page iii

1. Total Pages: 276

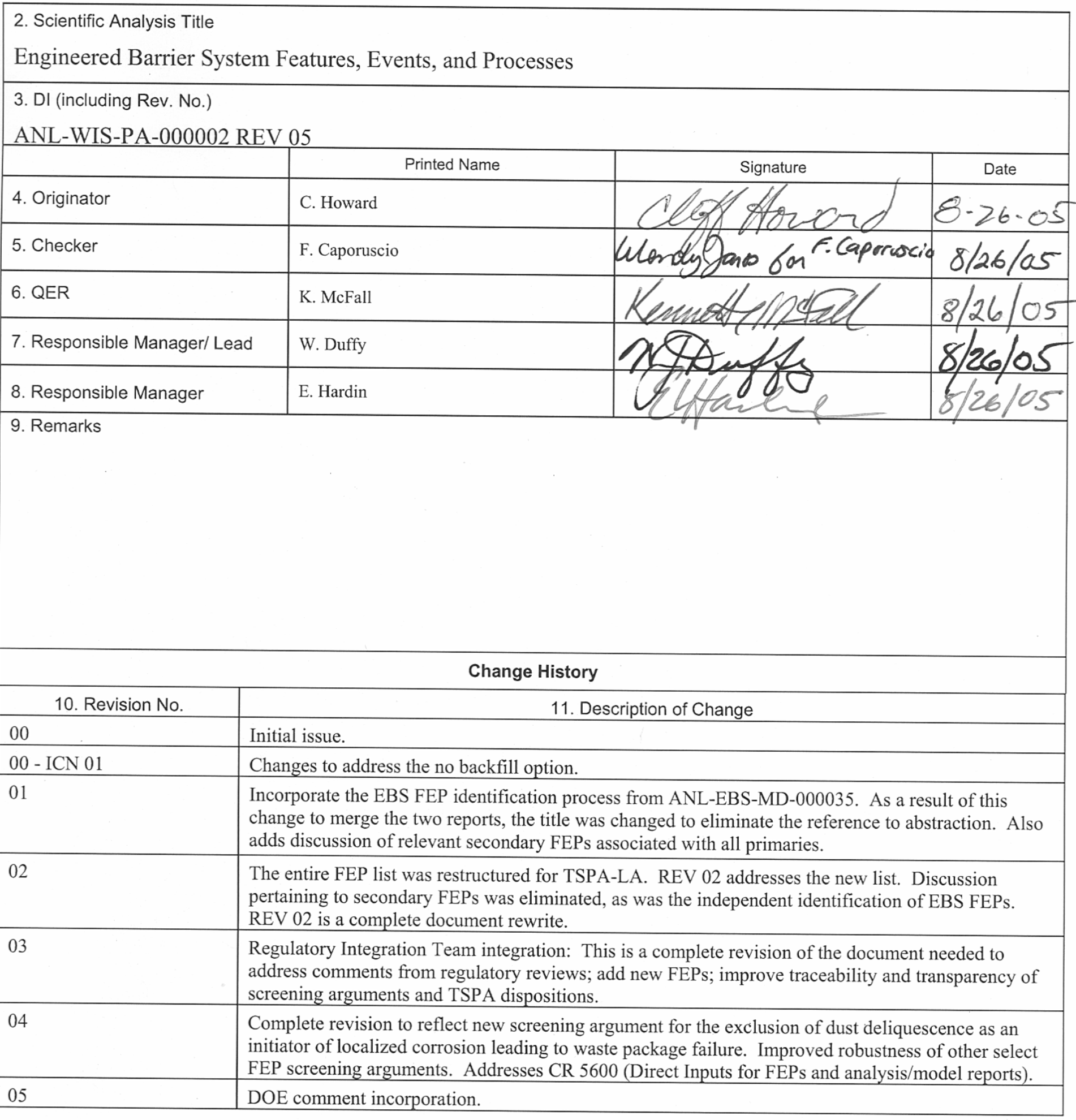




\section{CONTENTS}

Page

ACRONYMS AND ABBREVIATIONS ................................................................... xiii

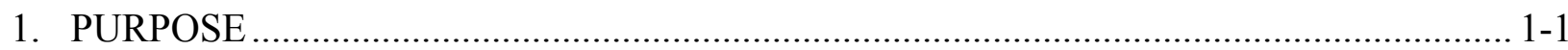

1.1 PLANNING AND DOCUMENTATION ........................................................ 1-2

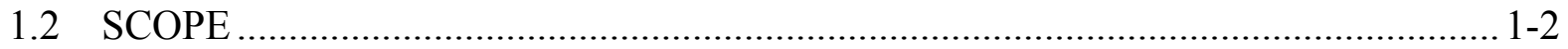

1.3 SCIENTIFIC ANALYSIS USE AND LIMITATIONS ...................................... 1-6

2. QUALITY ASSURANCE ................................................................................. 2-1

3. USE OF SOFTWARE ..................................................................................... $3-1$

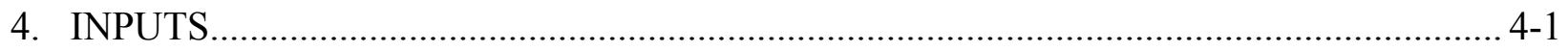

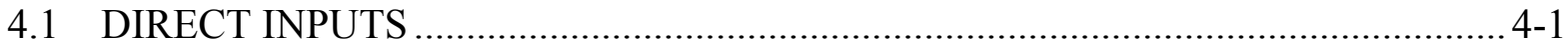

4.1.1 Direct Inputs....................................................................................... 4-1

4.1.2 Background, Technical Information Sources, and Literature Searches....... 4-15

4.2 CRITERIA ............................................................................................. 4-15

4.2.1 Project Requirements Document ..................................................... 4-15

4.2.2 Yucca Mountain Review Plan ................................................................. 4-15

4.2.3 FEPs Screening Criteria ................................................................... 4-19

4.2.4 Completion Criteria .............................................................................. 4-21

4.3 CODES, STANDARDS, AND REGULATIONS ............................................... 4-21

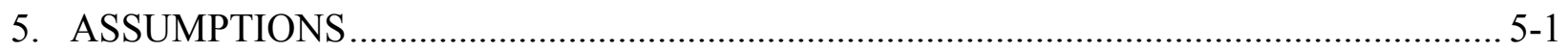

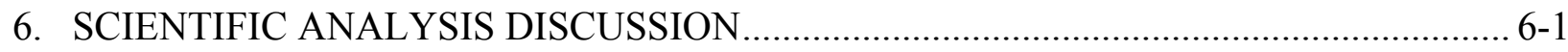

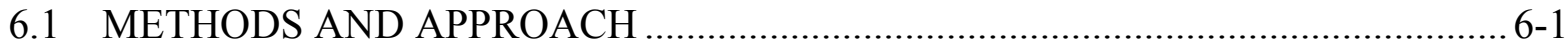

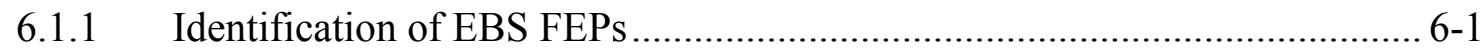

6.1.2 Screening of EBS FEPs ................................................................... $6-1$

Indirect Inputs .............................................................................. $6-3$

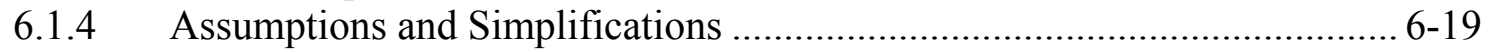

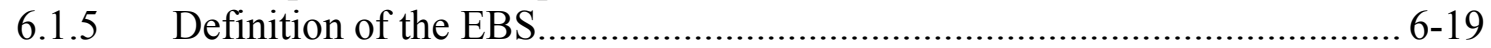

6.1.6 Intended Use and Limitations ....................................................... 6-36

6.2 EBS FEPS SCREENING AND ANALYSIS .................................................. 6-36

6.2.1 Chemical Effects of Excavation and Construction in EBS........................ 6-36

6.2.2 Mechanical Effects of Excavation and Construction in EBS .................... 6-38

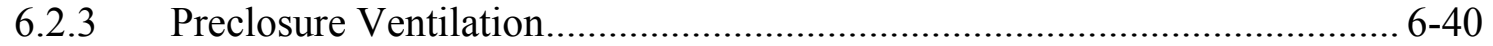

6.2.4 Undesirable Materials Left .................................................................... 6-41

6.2.5 Error in Waste Emplacement .................................................................. 6-42

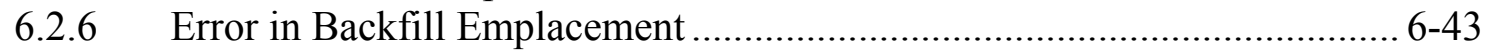

6.2.7 Fault Displacement Damages EBS Components ...................................... 6-43

6.2.8 Seismic Ground Motion Damages EBS Components ................................ 6-46

6.2.9 Seismic-Induced Rockfall Damages EBS Components ............................ 6-48

6.2.10 Seismic-Induced Drift Collapse Damages EBS Components .................... 6-51 


\section{CONTENTS (Continued)}

Page

6.2.11 Seismic-Induced Drift Collapse Alters In-Drift Thermohydrology............ 6-52

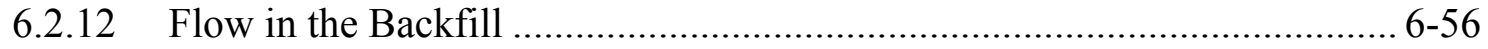

6.2.13 Chemical Properties and Evolution of Backfill ........................................ 6-57

6.2.14 Erosion or Dissolution of Backfill .......................................................... 6-57

6.2.15 Thermal-Mechanical Effects of Backfill ................................................ 6-58

6.2.16 Thermal-Mechanical Properties and Evolution of Backfill ........................ 6-58

6.2.17 Radionuclide Transport in Backfill..................................................... 6-59

6.2.18 Chemical Effects of Rock Reinforcement and Cementitious Materials in EBS .................................................................................. 6-59

6.2.19 Mechanical Effects of Rock Reinforcement Materials in EBS .................. 6-61

6.2.20 Flow Through Rock Reinforcement Materials in EBS .............................. 6-62

6.2.21 Mechanical Degradation of Emplacement Pallet.................................... 6-63

6.2.22 Mechanical Degradation of Invert ....................................................... 6-64

6.2.23 Chemical Degradation of Emplacement Pallet .......................................... 6-66

6.2.24 Chemical Degradation of Invert............................................................. 6-69

6.2.25 Effects of Drip Shield on Flow .......................................................... 6-70

6.2.26 Chemical Effects at EBS Component Interfaces ..................................... 6-71

6.2.27 Mechanical Effects at EBS Component Interfaces .................................... 6-72

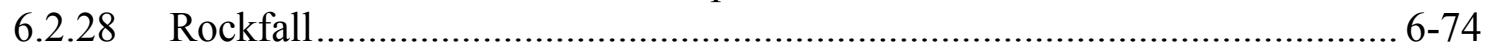

6.2.29 Drift Collapse.................................................................................... 6-76

6.2.30 Hydrostatic Pressure on Waste Package ................................................ 6-78

6.2.31 Hydrostatic Pressure on Drip Shield...................................................... 6-79

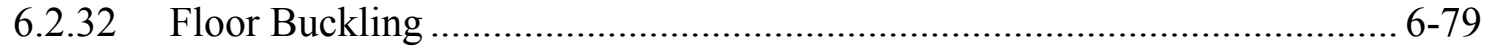

6.2.33 Effects of Rapid Influx into the Repository ............................................. 6-80

6.2.34 Repository Dry-Out Due to Waste Heat ............................................. 6-82

6.2.35 Condensation Forms on Roofs of Drifts (Drift-Scale Cold Traps).............. 6-83

6.2.36 Condensation Forms at Repository Edges (Repository-Scale

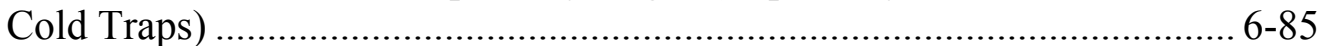

6low Through Invert .............................................................................. $6-87$

6.2.38 Capillary Effects (Wicking) in EBS ................................................... 6-88

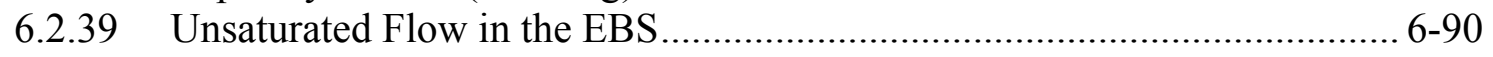

6.2.40 Saturated Flow in the EBS ................................................................ 6-91

6.2.41 Repository Resaturation Due to Waste Cooling ........................................ 6-93

6.2.42 Induced Hydrologic Changes in Invert .................................................... 6-94

6.2.43 Condensation on Underside of Drip Shield ............................................ 6-95

6.2.44 Consolidation of EBS Components ....................................................... 6-99

6.2.45 Chemical Characteristics of Water in Drifts ............................................ 6-101

6.2.46 Chemical Interaction with Corrosion Products....................................... 6-103

6.2.47 Volume Increase of Corrosion Products Impacts Other EBS Components ...................................................................... 6-104

6.2.48 Sorption of Dissolved Radionuclides in EBS ...................................... 6-105

6.2.49 Reduction-Oxidation Potential in Drifts .............................................. 6-106

6.2.50 Reaction Kinetics in Drifts............................................................... 6-10 


\section{CONTENTS (Continued)}

6.2.51 Diffusion of Dissolved Radionuclides in EBS...................................... 6-108

6.2.52 Advection of Dissolved Radionuclides in EBS ................................... 6-110

6.2.53 Sorption of Colloids in EBS ................................................................ 6-112

6.2.54 Advection of Colloids in EBS............................................................. 6-113

6.2.55 Filtration of Colloids in EBS …........................................................ 6-114

6.2.56 Transport of Particles Larger Than Colloids in EBS ............................... 6-115

6.2.57 Sorption of Colloids at Air-Water Interface....................................... 6-117

6.2.58 Diffusion of Colloids in EBS ................................................................ 6-118

6.2.59 Gravitational Settling of Colloids in EBS ............................................... 6-119

6.2.60 Coupled Effects on Radionuclide Transport in EBS .............................. 6-120

6.2.61 Localized Corrosion on Waste Package Outer Surface Due

to Deliquescence .............................................................................. 6-123

6.2.62 Localized Corrosion on Drip Shield Surfaces Due to Deliquescence ....... 6-127

6.2.63 Advection of Liquids and Solids through Cracks in the Waste Package... 6-128

6.2.64 Advection of Liquids and Solids through Cracks in the Drip Shield ........ 6-130

6.2.65 Microbial Activity in EBS ................................................................ 6-136

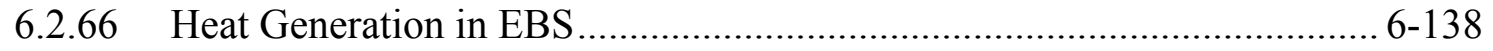

6.2.67 Non-Uniform Heat Distribution in EBS ............................................... 6-140

6.2.68 Exothermic Reactions in the EBS ........................................................ 6-141

6.2.69 Thermal Expansion/Stress of In-Drift EBS Components ......................... 6-142

6.2.70 Thermal Effects on Chemistry and Microbial Activity in the EBS .......... 6-144

6.2.71 Thermal Effects on Flow in the EBS ................................................ 6-145

6.2.72 Thermally Driven Flow (Convection) in Drifts ...................................... 6-146

6.2.73 Thermal Effects on Transport in EBS.................................................... 6-147

6.2.74 Gas Generation (Repository Pressurization).......................................... 6-149

6.2.75 Gas Generation (He) from Waste Form Decay...................................... 6-150

6.2.76 Gas Generation $\left(\mathrm{H}_{2}\right)$ from Waste Package Corrosion................................ 6-151

6.2.77 Gas Generation $\left(\mathrm{CO}_{2}, \mathrm{CH}_{4}, \mathrm{H}_{2} \mathrm{~S}\right)$ from Microbial Degradation ................ 6-153

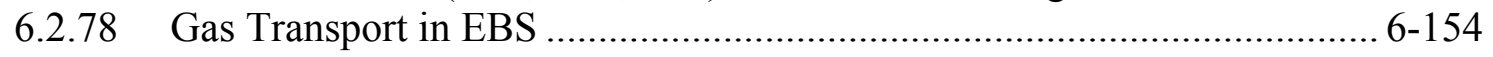

6.2.79 Effects of Radioactive Gases in EBS .................................................... 6-157

6.2.80 Gas Explosions in EBS .................................................................... 6-159

6.2.81 Radiolysis.................................................................................... $6-162$

6.2.82 Radiation Damage in EBS .................................................................. 6-164

6.2.83 Radiological Mutation of Microbes ........................................................ 6-165

6.2.84 Thermally-Induced Stress Changes in the Near-Field .............................. 6-166

6.2.85 Chemical Changes in the Near-Field from Backfill ................................. 6-168

6.2.86 Episodic or Pulse Release from Repository............................................. 6-168

6.2.87 Long-Term Release of Radionuclides from the Repository ..................... 6-170

6.2.88 Drift Shadow Forms below Repository ................................................... 6-170

6.2.89 Re-Dissolution of Precipitates Directs More Corrosive Fluids to

Waste Packages.......................................................................... 6-172

6.2.90 Seismic-Induced Drift Collapse Alters In-Drift Chemistry ...................... 6-173 


\section{CONTENTS (Continued)}

\section{Page}

7. CONCLUSIONS.................................................................................................. $7-1$

7.1 SATISFACTION OF ACCEPTANCE CRITERIA …............................................ 7-5

7.1.1 Acceptance Criteria from Section 4.2.2.1 of This Report and Section 2.2.1.2.1.3 of Yucca Mountain Review Plan, Final Report (NRC 2003 [DIRS 163274]), Scenario Analysis and Event Probability...... 7-5

7.1.2 Acceptance Criteria from Section 4.2.2.2 of This Report and Section 2.2.1.3.3.3 of Yucca Mountain Review Plan, Final Report (NRC 2003 [DIRS 163274]), Quantity and Chemistry of Water Contacting Engineered Barriers and Waste Forms

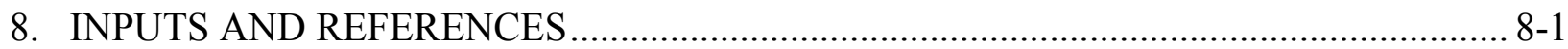

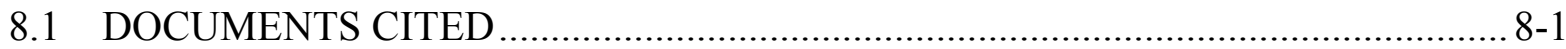

8.2 CODES, STANDARDS, REGULATIONS, AND PROCEDURES ....................... 8-12

8.3 SOURCE DATA, LISTED BY DATA TRACKING NUMBER ......................... 8-13

APPENDIX A - QUALIFICATION OF DIRECT INPUTS LISTED IN TABLE 4-1.......... A-1

APPENDIX B - QUALIFICATION OF DATA FROM CRAIG (2001 [DIRS 171411]) .......B-1

APPENDIX C - ANALYSIS OF ROCKFALL AND ITS IMPACT TO DRIP SHIELD DENTING AND CRACKING 


\section{FIGURES}

Page

6-1. Drift Cross-Section with Components of the EBS ................................................. 6-20

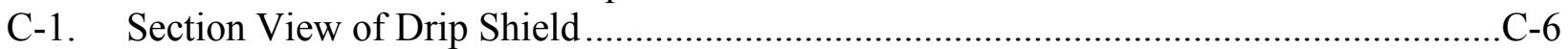

C-2. Definition of Impact Angle and Drip Shield Block Local Coordinate System ............... -7 


\section{INTENTIONALLY LEFT BLANK}




\section{TABLES}

Page

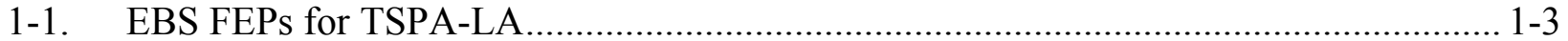

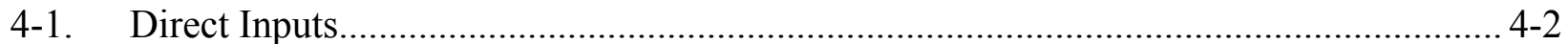

4-2. Applicable Regulatory Requirements ………................................................... 4-16

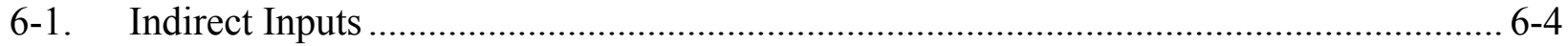

6-2. Sharing Reports and EBS Components Addressed in Each FEP ……….................... 6-22

7-1. Summary of EBS FEPs Screening Decisions ............................................................. 7-1

C-1. Selection of Blocks with Highest Impact Energy That Could Dent Drip Shield Crown

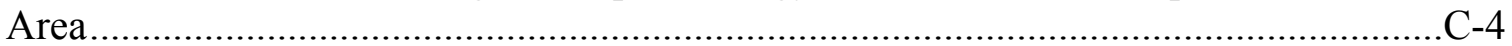

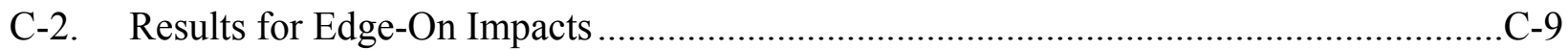




\section{INTENTIONALLY LEFT BLANK}




\section{ACRONYMS AND ABBREVIATIONS}

BSC

BWR

Bechtel SAIC Company, LLC

CSNF commercial spent nuclear fuel

DHLW

defense high-level radioactive waste

DOE

DSNF

U.S. Department of Energy

DTN

defense spent nuclear fuel

data tracking number

EBS

engineered barrier system

ECRB

Enhanced Characterization of the Repository Block

ESF

Exploratory Studies Facility

FEP feature, event, and process

HLW high-level (radioactive) waste

IDPS in-drift precipitates/salts (model)

IED information exchange drawing

ITWI important to waste isolation

MSTHM multiscale thermohydrologic model

MTHM metric tons of heavy metal

NRC U.S. Nuclear Regulatory Commission

PGV peak ground velocity

PWR pressurized water reactor

QARD Quality Assurance Requirements and Description

RH relative humidity

RMEI reasonably maximally exposed individual

RTA radionuclide transport abstraction (model)

SCC stress corrosion cracks

SNF spent nuclear fuel

TH thermal-hydrologic

THC thermal-hydrologic-chemical

THM thermal-hydrologic-mechanical

TSPA total system performance assessment

TSPA-LA total system performance assessment for the license application 


\section{ACRONYMS AND ABBREVIATIONS (Continued)}

TWP technical work plan

UZ unsaturated zone

YMP Yucca Mountain Project

YMRP Yucca Mountain Review Plan, Final Report 


\section{PURPOSE}

The purpose of this report is to evaluate and document the inclusion or exclusion of engineered barrier system (EBS) features, events, and processes (FEPs) with respect to models and analyses used to support the total system performance assessment for the license application (TSPA-LA). A screening decision, either Included or Excluded, is given for each FEP along with the technical basis for exclusion screening decisions. This information is required by the U.S. Nuclear Regulatory Commission (NRC) at 10 CFR 63.114 (d, e, and f) [DIRS 173273].

The FEPs addressed in this report deal with those features, events, and processes relevant to the EBS focusing mainly on those components and conditions exterior to the waste package and within the rock mass surrounding emplacement drifts. The components of the EBS are the drip shield, waste package, waste form, cladding, emplacement pallet, emplacement drift excavated opening (also referred to as drift opening in this report), and invert. FEPs specific to the waste package, cladding, and drip shield are addressed in separate FEP reports: for example, Screening of Features, Events, and Processes in Drip Shield and Waste Package Degradation (BSC 2005 [DIRS 174995]), Clad Degradation - FEPs Screening Arguments (BSC 2004 [DIRS 170019]), | and Waste-Form Features, Events, and Processes (BSC 2004 [DIRS 170020]).

For included FEPs, this report summarizes the implementation of the FEP in the TSPA-LA (i.e., how the FEP is included). For excluded FEPs, this analysis provides the technical basis for exclusion from TSPA-LA (i.e., why the FEP is excluded).

This report also documents changes to the EBS FEPs list that have occurred since the previous versions of this report. These changes have resulted due to a reevaluation of the FEPs for TSPA-LA as identified in Section 1.2 of this report and described in more detail in Section 6.1.1. This revision addresses updates in Yucca Mountain Project (YMP) administrative procedures as they pertain to this report; the current procedures are addressed in Section 2. This revision also addresses updates to the technical basis in supporting analysis and model reports and corroborative documentation, as presented in Sections 4 and 6 of this report. Finally, Sections 4, 5 , and 6 of this report provide additional information pertaining to the relevant FEPs-related Acceptance Criteria presented in Yucca Mountain Review Plan, Final Report (YMRP) (NRC 2003 [DIRS 163274], Sections 2.2.1.2.1.3 and 2.2.1.3.3.3).

The following documents provide the primary basis for the summaries of how included FEPs were integrated into the TSPA-LA model:

- Abstraction of Drift Seepage

- Drift Degradation Analysis

- Drift-Scale Coupled Processes (DST and TH Seepage) Models

- Drift-Scale THC Seepage Model

- EBS Radionuclide Transport Abstraction

- Engineered Barrier System: Physical and Chemical Environment

- Environment on the Surfaces of the Drip Shield and Waste Package Outer Barrier

- Evaluation of Potential Impacts of Microbial Activities on Drift Chemistry

- In-Drift Natural Convection and Condensation

- In-Drift Precipitates/Salts Model 
- Multiscale Thermohydrologic Model

- Post-Processing Analysis for THC Seepage

- Seismic Consequence Abstraction

- Ventilation Model and Analysis Report.

\subsection{PLANNING AND DOCUMENTATION}

This report satisfies the FEP analysis documentation requirements described in Technical Work Plan for: Revision to EBS FEPs Document (BSC 2005 [DIRS 173694]). This work constitutes a scientific analysis, and the documentation has been prepared according to LP-SIII.9Q-BSC, Scientific Analyses, and with related procedures as described in Section 2 of this report.

\subsection{SCOPE}

The scope of this report is to describe, evaluate, and document screening decisions and technical bases for the EBS FEPs for TSPA-LA. For FEPs that are included in the TSPA-LA, this report provides a TSPA-LA disposition, which is a consolidated summary of how the FEP has been included and addressed in the TSPA-LA model, based on the various supporting technical analysis reports and model reports that describe the inclusion of the FEP. For FEPs that are excluded from the TSPA-LA, this report provides a screening argument, which identifies the basis for the screening decision (i.e., low probability, low consequence, or by regulation) and presents the technical basis that supports that decision. It also provides appropriate references to project and non-project information that supports the exclusion.

In cases where a FEP covers multiple technical areas and is shared with other FEP reports, this report provides only a partial technical basis for the screening decision as it relates to EBS FEPs concerns (Table 1-1). The full technical basis for these shared FEPs is addressed, collectively, by all of the sharing FEP reports. Details regarding shared FEPs, specifically aspects presented in other FEP reports, are provided in Sections 6.1.5 and 6.2.

An overview of the YMP FEP analysis and scenario development process is available in The Development of the Total System Performance Assessment-License Application Features, Events, and Processes (BSC 2005 [DIRS 173800], Sections 2.4, 3, and 4), which describes the TSPA-LA FEP identification and screening process. As part of that process, the LA FEP List and Screening (DTN: MO0501SEPFEPLA.001 [DIRS 172601]) was developed. This database was used as an input to the EBS FEP analysis. The list of EBS TSPA-LA FEPs, presented in Table 1-1, was derived from DTN: MO0501SEPFEPLA.001 [DIRS 172601] (file FEPS_be.mdb, table "FEPs"). Deviations in two FEP titles and descriptions in DTN: MO0501SEPFEPLA.001 [DIRS 172601] are presented in Table 1-1, as well as throughout this report, and are documented in Technical Management Review Board (TMRB) Decision Proposal (TMRB-2005-047) (BSC 2005 [DIRS 174965]), and Technical Management Review Board (TMRB) Decision Proposal (TMRB-2005-050) (BSC 2005 [DIRS 174990]).

Direct inputs supporting the screening decisions are listed in Table 4-1. Indirect inputs supporting the screening decisions are listed in Table 6-1. The individual FEP discussions providing identification (FEP number, name, and description) and screening decision, screening argument, or total system performance assessment (TSPA) disposition are in Section 6.2. 
Table 1-1. EBS FEPs for TSPA-LA

\begin{tabular}{|c|c|c|c|}
\hline $\begin{array}{c}\text { FEP } \\
\text { Number }^{a}\end{array}$ & FEP Name ${ }^{a}$ & $\begin{array}{l}\text { Addressed } \\
\text { in Section }\end{array}$ & $\begin{array}{l}\text { Sharing } \\
\text { Report(s) }\end{array}$ \\
\hline 1.1.02.00.0A & Chemical effects of excavation and construction in EBS & 6.2 .1 & EBS \\
\hline 1.1.02.00.0B & Mechanical effects of excavation and construction in EBS & 6.2 .2 & EBS \\
\hline 1.1.02.02.0A & Preclosure ventilation & 6.2 .3 & EBS/UZ \\
\hline 1.1.02.03.0A & Undesirable materials left & 6.2 .4 & EBS \\
\hline 1.1.03.01.0A & Error in waste emplacement & 6.2 .5 & EBS/WP \\
\hline 1.1.03.01.0B & Error in backfill emplacement & 6.2 .6 & EBS \\
\hline 1.2.02.03.0A & Fault displacement damages EBS components & 6.2.7 & EBS/DE \\
\hline 1.2.03.02.0A & Seismic ground motion damages EBS components & 6.2 .8 & EBS/DE \\
\hline 1.2.03.02.0B & Seismic-induced rockfall damages EBS components & 6.2 .9 & EBS/DE \\
\hline 1.2.03.02.0C & Seismic-induced drift collapse damages EBS components & 6.2 .10 & EBS/DE \\
\hline 1.2.03.02.0D & Seismic-induced drift collapse alters in-drift thermohydrology & 6.2 .11 & EBS/DE \\
\hline 1.2.03.02.0E & Seismic-induced drift collapse alters in-drift chemistry & 6.2 .90 & EBS \\
\hline 2.1.03.10.0A & $\begin{array}{l}\text { Advection of liquids and solids through cracks in the } \\
\text { waste packages }\end{array}$ & 6.2 .63 & EBS \\
\hline 2.1.03.10.0B & $\begin{array}{l}\text { Advection of liquids and solids through cracks in the } \\
\text { drip shields }\end{array}$ & 6.2 .64 & EBS \\
\hline 2.1.04.01.0A & Flow in the backfill & 6.2 .12 & EBS \\
\hline 2.1.04.02.0A & Chemical properties and evolution of backfill & 6.2 .13 & EBS \\
\hline 2.1.04.03.0A & Erosion or dissolution of backfill & 6.2 .14 & EBS \\
\hline 2.1.04.04.0A & Thermal-mechanical effects of backfill & 6.2 .15 & EBS \\
\hline 2.1.04.05.0A & Thermal-mechanical properties and evolution of backfill & 6.2 .16 & EBS \\
\hline 2.1.04.09.0A & Radionuclide transport in backfill & 6.2 .17 & EBS \\
\hline 2.1.06.01.0A & $\begin{array}{l}\text { Chemical effects of rock reinforcement and cementitious } \\
\text { materials in EBS }\end{array}$ & 6.2 .18 & EBS \\
\hline 2.1.06.02.0A & Mechanical effects of rock reinforcement materials in EBS & 6.2 .19 & EBS \\
\hline 2.1.06.04.0A & Flow through rock reinforcement materials in EBS & 6.2 .20 & EBS \\
\hline 2.1.06.05.0A & Mechanical degradation of emplacement pallet & 6.2 .21 & EBS \\
\hline 2.1.06.05.0B & Mechanical degradation of invert & 6.2 .22 & EBS \\
\hline 2.1.06.05.0C & Chemical degradation of emplacement pallet & 6.2 .23 & EBS \\
\hline 2.1.06.05.0D & Chemical degradation of invert & 6.2 .24 & EBS \\
\hline 2.1.06.06.0A & Effects of drip shield on flow & 6.2 .25 & EBS \\
\hline 2.1.06.07.0A & Chemical effects at EBS component interfaces & 6.2 .26 & EBS \\
\hline 2.1.06.07.0B & Mechanical effects at EBS component interfaces & 6.2 .27 & EBS/WP \\
\hline 2.1.07.01.0A & Rockfall & 6.2 .28 & EBS/WP/CLAD \\
\hline 2.1.07.02.0A & Drift collapse & 6.2 .29 & EBS \\
\hline 2.1.07.04.0A & Hydrostatic pressure on waste package & 6.2 .30 & EBS \\
\hline 2.1.07.04.0B & Hydrostatic pressure on drip shield & 6.2 .31 & EBS \\
\hline 2.1.07.06.0A & Floor buckling & 6.2 .32 & EBS \\
\hline 2.1.08.01.0B & Effects of rapid influx into the repository & 6.2 .33 & EBS \\
\hline 2.1.08.03.0A & Repository dry-out due to waste heat & 6.2 .34 & EBS \\
\hline 2.1.08.04.0A & Condensation forms on roofs of drifts (drift-scale cold traps) & 6.2 .35 & EBS \\
\hline
\end{tabular}


Table 1-1. EBS FEPs for TSPA-LA (Continued)

\begin{tabular}{|c|c|c|c|}
\hline $\begin{array}{c}\text { FEP } \\
\text { Number }^{\mathrm{a}}\end{array}$ & FEP Name ${ }^{a}$ & $\begin{array}{l}\text { Addressed } \\
\text { in Section }\end{array}$ & $\begin{array}{l}\text { Sharing } \\
\text { Report(s) }^{\mathrm{a}}\end{array}$ \\
\hline 2.1.08.04.0B & $\begin{array}{l}\text { Condensation forms at repository edges (repository-scale } \\
\text { cold traps) }\end{array}$ & 6.2 .36 & EBS \\
\hline 2.1.08.05.0A & Flow through invert & 6.2 .37 & EBS \\
\hline 2.1.08.06.0A & Capillary effects (wicking) in EBS & 6.2 .38 & EBS \\
\hline 2.1.08.07.0A & Unsaturated flow in the EBS & 6.2 .39 & EBS \\
\hline 2.1.08.09.0A & Saturated flow in the EBS & 6.2 .40 & EBS \\
\hline 2.1.08.11.0A & Repository resaturation due to waste cooling & 6.2 .41 & EBS \\
\hline 2.1.08.12.0A & Induced hydrologic changes in invert & 6.2 .42 & EBS \\
\hline 2.1.08.14.0A & Condensation on underside of drip shield & 6.2 .43 & EBS \\
\hline 2.1.08.15.0A & Consolidation of EBS components & 6.2 .44 & EBS \\
\hline 2.1.09.01.0A & Chemical characteristics of water in drifts & 6.2 .45 & EBS \\
\hline 2.1.09.02.0A & Chemical interaction with corrosion products & 6.2 .46 & EBS/WF \\
\hline 2.1.09.03.0C & $\begin{array}{l}\text { Volume increase of corrosion products impacts other } \\
\text { EBS components }\end{array}$ & 6.2 .47 & EBS \\
\hline 2.1.09.05.0A & Sorption of dissolved radionuclides in EBS & 6.2 .48 & EBS \\
\hline 2.1.09.06.0B & Reduction-oxidation potential in drifts & 6.2 .49 & EBS \\
\hline 2.1.09.07.0B & Reaction kinetics in drifts & 6.2 .50 & EBS \\
\hline 2.1.09.08.0A & Diffusion of dissolved radionuclides in EBS & 6.2 .51 & EBS \\
\hline 2.1.09.08.0B & Advection of dissolved radionuclides in EBS & 6.2 .52 & EBS \\
\hline 2.1.09.19.0A & Sorption of colloids in EBS & 6.2 .53 & EBS \\
\hline 2.1.09.19.0B & Advection of colloids in EBS & 6.2 .54 & EBS \\
\hline 2.1.09.20.0A & Filtration of colloids in EBS & 6.2 .55 & EBS \\
\hline 2.1.09.21.0A & Transport of particles larger than colloids in EBS & 6.2 .56 & EBS \\
\hline 2.1.09.22.0A & Sorption of colloids at air-water interface & 6.2 .57 & EBS \\
\hline 2.1.09.24.0A & Diffusion of colloids in EBS & 6.2 .58 & EBS \\
\hline 2.1.09.26.0A & Gravitational settling of colloids in EBS & 6.2 .59 & EBS \\
\hline 2.1.09.27.0A & Coupled effects on radionuclide transport in EBS & 6.2 .60 & EBS \\
\hline 2.1.09.28.0A & $\begin{array}{l}\text { Localized corrosion on waste package outer surface due to } \\
\text { deliquescence }\end{array}$ & 6.2 .61 & $\mathrm{EBS} / \mathrm{WP}^{\mathrm{c}}$ \\
\hline 2.1.09.28.0B & $\begin{array}{l}\text { Localized corrosion on drip shield surfaces due to } \\
\text { deliquescence }^{\mathrm{d}}\end{array}$ & 6.2 .62 & EBS \\
\hline 2.1.10.01.0A & Microbial activity in EBS & 6.2 .65 & EBS \\
\hline 2.1.11.01.0A & Heat generation in EBS & 6.2 .66 & EBS \\
\hline 2.1.11.02.0A & Non-uniform heat distribution in EBS & 6.2 .67 & EBS \\
\hline 2.1.11.03.0A & Exothermic reactions in the EBS & 6.2 .68 & EBS/WF \\
\hline 2.1.11.07.0A & Thermal expansion/stress of in-drift EBS components & 6.2 .69 & EBS/WP \\
\hline 2.1.11.08.0A & $\begin{array}{l}\text { Thermal effects on chemistry and microbial activity in } \\
\text { the EBS }\end{array}$ & 6.2 .70 & EBS/WF \\
\hline 2.1.11.09.0A & Thermal effects on flow in the EBS & 6.2 .71 & EBS \\
\hline 2.1.11.09.0C & Thermally driven flow (convection) in drifts & 6.2 .72 & EBS \\
\hline 2.1.11.10.0A & Thermal effects on transport in EBS & 6.2 .73 & EBS \\
\hline 2.1.12.01.0A & Gas generation (repository pressurization) & 6.2 .74 & EBS \\
\hline
\end{tabular}


Table 1-1. EBS FEPs for TSPA-LA (Continued)

\begin{tabular}{|c|c|c|c|}
\hline $\begin{array}{c}\text { FEP } \\
\text { Number }^{\mathrm{a}}\end{array}$ & FEP Name ${ }^{a}$ & $\begin{array}{l}\text { Addressed } \\
\text { in Section }\end{array}$ & $\begin{array}{l}\text { Sharing } \\
\text { Report(s) }\end{array}$ \\
\hline 2.1.12.02.0A & Gas generation $(\mathrm{He})$ from waste form decay & 6.2 .75 & EBS/CLAD \\
\hline 2.1.12.03.0A & Gas generation $\left(\mathrm{H}_{2}\right)$ from waste package corrosion & 6.2 .76 & EBS/CLAD/WP \\
\hline 2.1.12.04.0A & Gas generation $\left(\mathrm{CO}_{2}, \mathrm{CH}_{4}, \mathrm{H}_{2} \mathrm{~S}\right)$ from microbial degradation & 6.2 .77 & EBS/WF \\
\hline 2.1.12.06.0A & Gas transport in EBS & 6.2 .78 & EBS \\
\hline 2.1.12.07.0A & Effects of radioactive gases in EBS & 6.2 .79 & EBS/WF \\
\hline 2.1.12.08.0A & Gas explosions in EBS & 6.2 .80 & EBS \\
\hline 2.1.13.01.0A & Radiolysis & 6.2 .81 & EBS/WF/WP \\
\hline 2.1.13.02.0A & Radiation damage in EBS & 6.2 .82 & EBS/WF/WP \\
\hline 2.1.13.03.0A & Radiological mutation of microbes & 6.2 .83 & EBS \\
\hline 2.2.01.02.0A & Thermally-induced stress changes in the near-field & 6.2 .84 & EBS/UZ \\
\hline 2.2.01.02.0B & Chemical changes in the near-field from backfill & 6.2 .85 & EBS \\
\hline 2.2.07.06.0A & Episodic or pulse release from repository & 6.2 .86 & EBS/UZ \\
\hline 2.2.07.06.0B & Long-term release of radionuclides from the repository & 6.2 .87 & EBS/UZ \\
\hline 2.2.07.21.0A & Drift shadow forms below repository & 6.2 .88 & EBS \\
\hline 2.2.08.04.0A & $\begin{array}{l}\text { Re-dissolution of precipitates directs more corrosive fluids to } \\
\text { waste packages }\end{array}$ & 6.2 .89 & EBS/UZ \\
\hline
\end{tabular}

a Source: DTN: MO0501SEPFEPLA.001 [DIRS 172601], file FEPS_be.mdb, table "FEPS." Sharing reports are in the column labeled "AMR" in the table "FEPS." Use the arrow keys ("<" and ">") in the "AMR" cell of the table "FEPS" to identify multiple sharing reports. Deviations in two FEP titles and descriptions in DTN: MO0501SEPFEPLA.001 [DIRS 172601] are documented in Technical Management Review Board (TMRB) Decision Proposal. TMRB-2005-047 (BSC 2005 [DIRS 174965]), and Technical Management Review Board (TMRB) Decision Proposal. TMRB-2005-050 (BSC 2005 [DIRS 174990]). (See footnotes b and d below.)

b Source: Technical Management Review Board (TMRB) Decision Proposal (TMRB-2005-047) (BSC 2005 [DIRS 174965]).

${ }^{c}$ This FEP was added to the WP sharing report, but the shared status is not reflected in the source data tracking number (DTN).

d Source: Technical Management Review Board (TMRB) Decision Proposal (TMRB-2005-050) (BSC 2005 [DIRS 174990]).

NOTES: "CLAD" designates the report Clad Degradation - FEPS Screening Arguments (BSC 2004 [DIRS 170019]).

"DE" designates the report Features, Events, and Processes: Disruptive Events (BSC 2005 [DIRS 173981]).

"EBS" designates the current report.

"WF" designates the report Waste-Form Features, Events, and Processes (BSC 2004 [DIRS 170020]).

"WP" designates the report Screening of Features, Events, and Processes in Drip Shield and Waste Package Degradation (BSC 2005 [DIRS 174995]).

"UZ" designates the report Features, Events, and Processes in UZ Flow and Transport (BSC 2005 [DIRS 174191]). 


\subsection{SCIENTIFIC ANALYSIS USE AND LIMITATIONS}

This report is intended for use as documentation for inclusion or exclusion of EBS FEPs within or from the TSPA-LA model. The following limitations apply to this report:

- Because this report references supporting reports and controlled documents as direct inputs, its limitations inherently include any limitations or constraints cited in those reports or controlled documents.

- In cases in which FEPs are shared, the scope of this report is limited to topics relevant to the EBS components and integrated system. The full technical basis for these shared FEPs is addressed, collectively, by all of the sharing FEP reports.

- The results of the FEPs screening presented herein are specific to the repository design and processes for the YMP available at the time of the TSPA-LA. Changes in direct inputs listed in Section 4.1, in baseline conditions used for this evaluation, or in other subsurface conditions, will need to be evaluated to determine whether the changes are within the limits stated in the FEP evaluations. Engineering and design changes are subject to evaluation to determine whether there are any adverse impacts to safety, as codified at 10 CFR 63.73 and in Subparts F and G [DIRS 173273]. See also the requirements at 10 CFR 63.44 [DIRS 173273]. 


\section{QUALITY ASSURANCE}

This report has been prepared in accordance with Technical Work Plan for: Revision to EBS FEPs Document (BSC 2005 [DIRS 173694]). As described in Section 8 of the technical work plan (TWP), the work presented in this document is subject to requirements set forth in Quality Assurance Requirements and Description (QARD) (DOE 2004 [DIRS 171539]). The activities associated with the development of this report and the supporting analyses have been performed in accordance with the TWP. Approved quality assurance procedures identified in Section 4 of the TWP have been used to conduct and document the activities described in this report. Accordingly, this document has been prepared in accordance with LP-SIII.9Q-BSC, and reviewed in accordance with LP-2.14Q-BSC, Document Review. All input data are identified and tracked in accordance with LP-3.15Q-BSC, Managing Technical Product Inputs.

An evaluation conducted in accordance with AP-SV.1Q, Control of the Electronic Management of Information, has determined that this work is subject to requirements to manage and control electronic data. Section 8.4 of the TWP (BSC 2005 [DIRS 173694]) documents the controls established to ensure that the procedural requirements have been met.

This report contributes to the analysis and modeling used to support performance assessment; the FEPs documented herein involve the investigations of items or barriers given in Q-List (BSC 2005 [DIRS 174269]) and have the potential to affect the definition of the performance of the natural barriers and various EBS components included on the Q-list. The following EBS components - invert, waste package, waste emplacement pallet, waste form, cladding, emplacement drift excavated opening, and drip shield-have been identified as important to waste isolation in accordance with AP-2.22Q, Classification Analyses and Maintenance of the Q List, and are therefore classified as "Safety Category" on the Q-list (BSC 2005 [DIRS 174269], Appendix A). The results of this report are important to the demonstration of compliance with the postclosure performance objectives prescribed in 10 CFR 63.113 [DIRS 173273]. The report contributes to the analysis and modeling data used to support postclosure performance assessment; the conclusions do not directly impact engineered features important to preclosure safety, as defined in AP-2.22Q. 


\section{INTENTIONALLY LEFT BLANK}




\section{USE OF SOFTWARE}

This report uses no computational software and is therefore not subject to software controls. The analyses and arguments presented herein are based on guidance and regulatory requirements, results of analyses presented and documented in other reports, or on other technical literature. Software and models used in the supporting documents are cited in this report for traceability and transparency purposes, but were not used for the development of this report.

This report was developed using only commercially approved software (Microsoft ${ }^{\circledR}$ Word $_{2000}$ for word processing), which is exempt from qualification requirements in accordance with LP-SI.11Q-BSC, Software Management.

This report also uses the standard functions of commercial off-the-shelf software (Microsoft ${ }^{\circledR}$ Excel 2000) for spreadsheets and graphical displays of selected results. There were no additional applications (routines or macros) developed using this commercial off-the-shelf software, and hence it is exempt from qualification requirements in accordance with LP-SI.11Q-BSC. 


\section{INTENTIONALLY LEFT BLANK}




\section{INPUTS}

LP-3.15Q-BSC categorizes technical product input usage as either direct input or indirect input. Direct input is used to develop the results or conclusions in a technical product. Indirect input is used to provide additional information that is not used in the development of results or conclusions. Direct inputs are addressed in this section. Indirect inputs are addressed in Section 6.1.

Section 4.1 identifies all direct inputs used in this FEP report. The direct inputs were obtained from controlled source documents and other appropriate sources in accordance with LP-SIII.9Q-BSC and documented in accordance with LP-3.15Q-BSC. Section 4.2 identifies the criteria described in Section 3 of the TWP (BSC 2005 [DIRS 173694]). Section 4.3 identifies applicable codes and standards.

\subsection{DIRECT INPUTS}

\subsubsection{Direct Inputs}

The LA FEP List and Screening (DTN: MO0501SEPFEPLA.001 [DIRS 172601], file FEPS_be.mdb, table "FEPS") was used as a direct input to provide the list of EBS FEPs for screening in this report. The LA FEP List and Screening identifies a FEP report or a set of sharing FEP reports for each FEP (to locate sharing reports within the source DTN cited above, see footnote "a" in Table 1-1). Deviations in two FEP titles and descriptions in DTN: MO0501SEPFEPLA.001 [DIRS 172601] are documented in Technical Management Review Board (TMRB) Decision Proposal (TMRB-2005-047) (BSC 2005 [DIRS 174965]), and Technical Management Review Board (TMRB) Decision Proposal (TMRB-2005-050) (BSC 2005 [DIRS 174990]). Direct inputs used for the FEP screening analysis are listed in Table 4-1. Justification for data in Table 4-1 obtained from outside sources that are not established fact is provided in Appendix A. Reports that are no longer maintained as an active part of the YMP technical basis and cited as direct input are qualified per LP-SIII.2Q-BSC, Qualification of Unqualified Data, in Appendix B. 


\begin{tabular}{|c|c|c|c|}
\hline Technical Product Input Source Title & Location in Source & Where Used in This Report & Description \\
\hline \multirow{3}{*}{$\begin{array}{l}10 \text { CFR 63. } 2005 \text { Energy: Disposal of High-Level } \\
\text { Radioactive Wastes in a Geologic Repository at } \\
\text { Yucca Mountain, Nevada. } \\
\text { [DIRS 173273] }\end{array}$} & $\begin{array}{l}10 \text { CFR } 63.114(e, f), \\
10 \text { CFR } 63.342\end{array}$ & \multicolumn{2}{|c|}{ Sections 6.1.2, 4.2.3; Table 4-2Screening criteria for FEPs } \\
\hline & 10 CFR 63.114 & Appendix C, Section C.2.3 & $\begin{array}{l}\text { Seismic events considered by performance } \\
\text { assessment }\end{array}$ \\
\hline & 10 CFR $63.102(j)$ & Section 4.2 .3 & Concept of performance assessment \\
\hline $\begin{array}{l}\text { ASM (American Society of Metals) 1961. "Properties and } \\
\text { Selection of Metals." } \\
\text { [DIRS 170284] }\end{array}$ & pp. 537 to 539 & Appendix C & $\begin{array}{l}\text { Titanium is susceptible to creep at } \\
\text { lower temperatures }\end{array}$ \\
\hline \multirow{3}{*}{$\begin{array}{l}\text { Bird, R.B.; Stewart, W.E.; and Lightfoot, E.N. } 1960 . \\
\text { Transport Phenomena. } \\
\text { [DIRS 103524] }\end{array}$} & pp. 565 to 567 & $\begin{array}{l}\text { Sections } 6.2 .60,6.2 .73 \\
\text { Appendix A }\end{array}$ & Soret effect \\
\hline & Equation $18.5-21$ & Appendix A & Mass flux relationship \\
\hline & Section 16.5 & Section 6.2 .73 & Stokes-Einstein equation \\
\hline $\begin{array}{l}\text { BSC (Bechtel SAIC Company) 2001. Performance } \\
\text { Assessment of a Potential Post-Closure Pyrophoric } \\
\text { Event Involving Uranium Metal Spent Fuel. } \\
\text { [DIRS 171508] }\end{array}$ & Section 5.2.6 & Section 6.2.68; Appendix A & Energy from oxidation of $\mathrm{U}$ metal \\
\hline $\begin{array}{l}\text { BSC 2001. Plugging of Stress Corrosion Cracks } \\
\text { by Precipitates. } \\
\text { [DIRS 156807] }\end{array}$ & Section 6.3 & Section 6.2 .64 & $\begin{array}{l}\text { Expected rate of SCC plugging due to } \\
\text { calcite precipitation }\end{array}$ \\
\hline $\begin{array}{l}\text { BSC 2003. Radiological Releases Due to Air and Silica } \\
\text { Dust Activation in Emplacement Drifts. } \\
\text { [DIRS 164562] }\end{array}$ & $\begin{array}{l}\text { Section 5.7.1; Tables 5-10, } \\
5-11\end{array}$ & Sections $6.2 .78,6.2 .79$ & Calculation of activation product quantities \\
\hline $\begin{array}{l}\text { BSC 2003. Subsurface Facilities Overall Layout. } \\
\text { [DIRS 165315] }\end{array}$ & Entire & Section 6.2 .82 & $\begin{array}{l}\text { Locations of each of the ramps, portals and } \\
\text { ventilation shafts and raises are shown not } \\
\text { to be in emplacement drifts }\end{array}$ \\
\hline $\begin{array}{l}\text { BSC 2004. 21-PWR Waste Package Configuration. } \\
\text { [DIRS 170710] }\end{array}$ & Entire & Section 6.2 .69 & $\begin{array}{l}\text { Current waste package designs also } \\
\text { require large longitudinal barrier gaps }\end{array}$ \\
\hline \multirow{2}{*}{$\begin{array}{l}\text { BSC 2004. Abstraction of Drift Seepage. } \\
\text { [DIRS 169131] }\end{array}$} & Sections $6.4 .2 .5,6.5 .1 .6$ & Section 6.2 .20 & Effect of rock bolts on seepage \\
\hline & Section 6.4.4; Figure 6.4-32 & Section 6.2 .84 & $\begin{array}{l}\text { Effects of thermal induced stress } \\
\text { changes around the emplacement drifts } \\
\text { on drift seepage }\end{array}$ \\
\hline
\end{tabular}


Table 4-1. Direct Inputs (Continued)

\begin{tabular}{|c|c|c|c|}
\hline Technical Product Input Source Title & Location in Source & Where Used in This Report & Description \\
\hline \multirow[t]{2}{*}{$\begin{array}{l}\text { BSC 2004. Abstraction of Drift-Scale Coupled Processes. } \\
\text { [DIRS 169617] }\end{array}$} & Section 8.2 & Section 6.2.90; Appendix A & $\begin{array}{l}\text { Predicted chemistries resulting from } \\
\text { drift degradation }\end{array}$ \\
\hline & Sections $6.4,6.4 .4 .4$ & Section 6.2 .73 & $\begin{array}{l}\text { Evaluation to determine the potential for } \\
\text { sorption coefficients to vary with } \\
\text { temperature on substrates (tuff and } \\
\text { hematite) relevant to the repository }\end{array}$ \\
\hline $\begin{array}{l}\text { BSC 2004. Aging and Phase Stability of Waste } \\
\text { Package Outer Barrier. } \\
\text { [DIRS 171924] }\end{array}$ & Section 8 & Section 6.2 .33 & $\begin{array}{l}\text { Metallurgical effects below } 300^{\circ} \mathrm{C} \text { in } \\
\text { waste packages }\end{array}$ \\
\hline $\begin{array}{l}\text { BSC 2004. Aqueous Corrosion Rates for Waste Package } \\
\text { Materials. } \\
\text { [DIRS 169982] }\end{array}$ & p. $6-40$ & Section 6.2 .44 & Corrosion of drip shield \\
\hline $\begin{array}{l}\text { BSC 2004. Clad Degradation - FEPs Screening } \\
\text { Arguments. } \\
\text { [DIRS 170019] }\end{array}$ & Sections $6.2 .23,6.2 .24$ & $\begin{array}{l}\text { Sections } 6.2 .75,6.2 .76,6.2 .78 \\
6.2 .79\end{array}$ & Chemical effects of hydrogen and helium \\
\hline \multirow{2}{*}{$\begin{array}{l}\text { BSC 2004. Commercial SNF Waste Package } \\
\text { Design Report. } \\
\text { [DIRS 169766] }\end{array}$} & Section 7.1.1.2.5 & Section 6.2 .27 & Capability of waste package to self support \\
\hline & Section 7.1.1.2.5 & Section 6.2 .27 & Maximum stress of the waste package \\
\hline \multirow{5}{*}{$\begin{array}{l}\text { BSC 2004. D\&E / PA/C IED Emplacement Drift } \\
\text { Configuration and Environment. } \\
\text { [DIRS 168489] }\end{array}$} & Figure 1 & Section 6.2 .22 & $\begin{array}{l}\text { EBS component design to } \\
\text { accommodate displacement }\end{array}$ \\
\hline & Figure 1 & Sections 6.2.23, 6.2.24 & Invert design \\
\hline & Figure 1 & Section 6.2 .9 & $\begin{array}{l}\text { Minimum gap between the drip shield and } \\
\text { waste package outer barrier }\end{array}$ \\
\hline & Entire & Section 6.2 .47 & $\begin{array}{l}\text { Loads due to volume expansion of carbon } \\
\text { steel materials }\end{array}$ \\
\hline & Figure 1 & Sections 6.2.26, 6.2.27 & Steel invert structure frame work \\
\hline $\begin{array}{l}\text { BSC 2004. D\&E / PA/C IED Subsurface Facilities. } \\
\text { [DIRS 168370] }\end{array}$ & Table 8 & $\begin{array}{l}\text { Section 6.2.64; Appendix C, } \\
\text { Section C.1 }\end{array}$ & $\begin{array}{l}\text { Repository emplacement area in lithophysal } \\
\text { rock }\end{array}$ \\
\hline \multirow{2}{*}{$\begin{array}{l}\text { BSC 2004. D\&E/RIT IED Subsurface Facilities } \\
\text { [Sheet } 1 \text { of 4]. } \\
\text { [DIRS 172801] }\end{array}$} & Table 2 & $\begin{array}{l}\text { Sections } 6.2 .1,6.2 .30,6.2 .31 \\
6.2 .33,6.2 .40,6.2 .42\end{array}$ & Repository elevation \\
\hline & Entire & Section 6.2 .18 & Standoff from emplacement drift \\
\hline $\begin{array}{l}\text { BSC 2004. Design and Engineering, Interlocking } \\
\text { Drip Shield Configuration. } \\
\text { [DIRS 168067] }\end{array}$ & Entire & Sections 6.2.32, 6.2 .69 & Overlap between adjacent drip shields \\
\hline
\end{tabular}




\begin{tabular}{|c|c|c|c|}
\hline Technical Product Input Source Title & Location in Source & Where Used in This Report & Description \\
\hline $\begin{array}{l}\text { BSC 2004. Development of Earthquake Ground Motion } \\
\text { Input for Preclosure Seismic Design and Postclosure } \\
\text { Performance Assessment of a Geologic Repository at } \\
\text { Yucca Mountain, NV. } \\
\text { [DIRS 170027] }\end{array}$ & Tables $6.3-14,6.3-16,6.3-18$ & $\begin{array}{l}\text { Appendix C, Section C.2.1; } \\
\text { Table C-1 }\end{array}$ & PGV values for vibratory ground motions \\
\hline $\begin{array}{l}\text { BSC 2004. Development of Numerical Grids for UZ Flow } \\
\text { and Transport Modeling. } \\
\text { [DIRS 169855] }\end{array}$ & Figure 6-2 & $\begin{array}{l}\text { Sections 6.2.1, 6.2.30, 6.2.31, } \\
6.2 .33,6.2 .40,6.2 .42\end{array}$ & Water table elevation \\
\hline \multirow{4}{*}{$\begin{array}{l}\text { BSC 2004. Dose Rate Calculation for 21-PWR } \\
\text { Waste Package. } \\
\text { [DIRS 172227] }\end{array}$} & Section 6.5 & Section 6.2 .82 & Ground support radiation damage \\
\hline & Table 6.4-3 & Section 6.2 .81 & $\begin{array}{l}\text { Maximum gamma radiation dose on } \\
\text { 21-PWR WP }\end{array}$ \\
\hline & Table 6.3-2 & Section 6.2 .81 & $\begin{array}{l}\text { Gamma versus neutron radiation level of } \\
\text { PWR SNF }\end{array}$ \\
\hline & Table 6.4-3 & Section 6.2 .81 & Radiation level after 100 years \\
\hline \multirow[t]{12}{*}{$\begin{array}{l}\text { BSC 2004. Drift Degradation Analysis. } \\
\text { [DIRS 166107] }\end{array}$} & $\begin{array}{l}\text { Sections } 6.2,6.3 .1 .3,6.3 .1 .4 \\
6.4 .2 .3,8.1\end{array}$ & Section 6.2 .84 & Thermal effects on stresses \\
\hline & $\begin{array}{l}\text { Sections } 6.3,6.3 .1 .6 .1 \\
6.3 .1 .6 .4,6.4,8.1\end{array}$ & Sections 6.2.9, 6.2.10, 6.2.90 & $\begin{array}{l}\text { Potential rock fall or drift collapse } \\
\text { and rockfalls }\end{array}$ \\
\hline & Section 8.1 & Section 6.2.19 & Degradation of rock-reinforcement material \\
\hline & $\begin{array}{l}\text { Sections } 6,6.3,6.3 .1 .3 \\
\text { 6.3.1.5, 6.3.1.2.6, 6.4, 6.4.2.1, } \\
\text { 6.4.2.4.2, 6.4.3, 8.1, S.3.4.1 }\end{array}$ & Sections 6.2.28, 6.2.29 & $\begin{array}{l}\text { Calculations and consequences of } \\
\text { rockfall and drift collapse: maximum } \\
\text { and total rockfall }\end{array}$ \\
\hline & Section 6.1.4 & Sections $6.2 .74,6.2 .80$ & Pervasive fracture network in the rock mass \\
\hline & Figure 6-42 & Figure C-2 & $\begin{array}{l}\text { Definition of impact angle and drip shield } \\
\text { block local coordinate system }\end{array}$ \\
\hline & Section 6.3 & Section 6.2 .64 & $\begin{array}{l}\text { Rockfall is predicted to occur in the } \\
\text { nonlithophysal units }\end{array}$ \\
\hline & \begin{tabular}{|l|} 
Sections 6.3, 6.3.1.2; \\
Figure 6-38; Appendix I \\
\end{tabular} & $\begin{array}{l}\text { Appendix C, Sections C.1, } \\
\text { C. } 2.2\end{array}$ & Rockfall results \\
\hline & Table E-9 & Appendix C, Section C.1 & Strength of lithophysal units \\
\hline & Section 8.1 & Appendix C, Section C.1 & $\begin{array}{l}\text { Rockfall in lithophysal and } \\
\text { nonlithophysal units }\end{array}$ \\
\hline & Table E-8 & Appendix C & Strength of nonlithophysal units \\
\hline & Sections 6.4.3, B.1 & Section 6.2 .64 & $\begin{array}{l}\text { Stress-controlled raveling of small rock } \\
\text { fragments in lithophysal units }\end{array}$ \\
\hline
\end{tabular}


Table 4-1. Direct Inputs (Continued)

\begin{tabular}{|c|c|c|c|}
\hline Technical Product Input Source Title & Location in Source & Where Used in This Report & Description \\
\hline \multirow{4}{*}{$\begin{array}{l}\text { BSC 2004. Drip Shield and Waste Package } \\
\text { Emplacement Pallet Design Report. } \\
\text { [DIRS 166879] }\end{array}$} & Sections 5.1.2, 5.2.2, 5.2.2.2 & Section 6.2 .26 & Mechanical loading at EBS interfaces \\
\hline & Sections 5.2.2, 7.2.2 & Sections 6.2.23 & Longevity of the emplacement pallet \\
\hline & Sections 6.1.1, 7.2.2 & Sections 6.2.21, 6.2.23 & Conservative pallet design \\
\hline & Sections 5.2, 5.1.2, 7.1.1 & Section 6.2 .27 & Mechanical loading at EBS interfaces \\
\hline $\begin{array}{l}\text { BSC 2004. Drip Shield Structural Response to Rock Fall. } \\
\text { [DIRS 168993] }\end{array}$ & Section 3.12, 6 & Section 6.2 .9 & Drip shield dynamic analysis \\
\hline $\begin{array}{l}\text { BSC 2004. DSNF and Other Waste Form } \\
\text { Degradation Abstraction. } \\
\text { [DIRS 172453] }\end{array}$ & Table 6-2 & Sections 6.2.68 & $\begin{array}{l}\text { No temperature dependence in model } \\
\text { and complete degradation in one time } \\
\text { step DSNF }\end{array}$ \\
\hline \multirow{2}{*}{$\begin{array}{l}\text { BSC 2004. Estimation of Mechanical Properties of } \\
\text { Crushed Tuff for Use as Ballast Material in Emplacement } \\
\text { Drifts. } \\
\text { [DIRS 168138] }\end{array}$} & Sections $7.10 .2,8$ & Section 6.2 .22 & Invert and backfill properties \\
\hline & Sections $7.9,7.10,7.11$ & Section 6.2 .22 & $\begin{array}{l}\text { Degradation, bearing capacity, and } \\
\text { long-term settlement properties }\end{array}$ \\
\hline \multirow{2}{*}{$\begin{array}{l}\text { BSC 2004. Evaluation of Emplacement Drift Stability } \\
\text { for KTI Resolutions. } \\
\text { [DIRS 168889] }\end{array}$} & Table 6-4.3 & Section 6.2 .22 & Drift thermal stress response \\
\hline & Table 6.4-3 & Section 6.2 .32 & Vertical displacement of drift floor \\
\hline \multirow{3}{*}{$\begin{array}{l}\text { BSC 2004. Evaluation of Potential Impacts of Microbial } \\
\text { Activities on Drift Chemistry. } \\
\text { [DIRS 169991] }\end{array}$} & $\begin{array}{l}\text { Sections } 6.1 .3,6.4,6.5,6.5 .1 \\
6.5 .2,6.5 .3,6.5 .4,7.1\end{array}$ & $\begin{array}{l}\text { Sections } 6.2 .18,6.2 .23,6.2 .24 \\
6.2 .65,6.2 .78,6.2 .79,6.2 .83 \\
\end{array}$ & Impacts of in-drift microbial activities \\
\hline & $\begin{array}{l}\text { Sections } 6.1 .3,6.4,6.4 .2,6.5 \text {, } \\
6.5 .1 ; \text { Table } 6.1-2\end{array}$ & Section 6.2 .77 & $\begin{array}{l}\text { Metabolic products of bacteria: Oxidizing } \\
\text { conditions and role in minimizing } \mathrm{H}_{2} \mathrm{~S}\end{array}$ \\
\hline & Section 6.1.3 & Section 6.2 .80 & Methane generation by microbes \\
\hline \multirow{4}{*}{$\begin{array}{l}\text { BSC 2004. General Corrosion and Localized Corrosion } \\
\text { of the Drip Shield. } \\
\text { [DIRS 169845] }\end{array}$} & Sections 6.3.1, 8.3 & Sections $6.2 .76,6.2 .90$ & Corrosion of drip shield \\
\hline & Section $6.9 .1,8.3,8.4$ & Section 6.2 .43 & Corrosion of drip shield \\
\hline & Sections $6.6,8.4$ & Section 6.2 .62 & $\begin{array}{l}\text { The corrosion behavior of the Titanium } \\
\text { Grade } 7 \text { drip shield material }\end{array}$ \\
\hline & Section 6.3 & Section 6.2 .80 & $\begin{array}{l}\text { Resistance of Alloy } 22 \text { to } \\
\text { localized corrosion }\end{array}$ \\
\hline \multirow{3}{*}{$\begin{array}{l}\text { BSC 2004. General Corrosion and Localized Corrosion } \\
\text { of Waste Package Outer Barrier. } \\
\text { [DIRS 169984] }\end{array}$} & Sections $6.4 .1,8.1$ & Sections $6.2 .23,6.2 .76$ & Corrosion mechanism and effect \\
\hline & $\begin{array}{l}\text { Sections 6.4.3.4, 8.1, 8.3; } \\
\text { Equation 6-28 }\end{array}$ & Section $6.4 .43,6.4 .44$ & Corrosion of waste package \\
\hline & Section 6.4.4 & Section 6.2 .44 & Outer barrier localized corrosion \\
\hline
\end{tabular}




\begin{tabular}{|c|c|c|c|}
\hline Technical Product Input Source Title & Location in Source & Where Used in This Report & Description \\
\hline \multirow[t]{2}{*}{$\begin{array}{l}\text { BSC 2004. In-Drift Natural Convection } \\
\text { and Condensation. } \\
\text { [DIRS 164327] }\end{array}$} & $\begin{array}{l}\text { Sections 6.3.1, 6.3.3.2.1, } \\
\text { 6.3.5.1.3, 6.3.7.2, 6.3.7.2.3, } \\
\text { 6.3.7.2.4, 8; Figures 6.3.5-13, } \\
\text { H.2-1, H.2-5, I.2-3, I.2-7, J-1; } \\
\text { Tables 7.4.1-23, 7.4.1-24 } \\
\end{array}$ & Section 6.2 .43 & In-drift condensation \\
\hline & Section 8.3.1.1 & Section 6.2 .42 & Effect of condensation on the invert \\
\hline $\begin{array}{l}\text { BSC 2004. Multiple Rock Fall on Drip Shield. } \\
\text { [DIRS 171756] }\end{array}$ & Section 6.1 & Section 6.2 .28 & Effect of rockfall on drip shield \\
\hline \multirow[t]{4}{*}{$\begin{array}{l}\text { BSC 2004. Postclosure Modeling and Analyses } \\
\text { Design Parameters. } \\
\text { [DIRS 169885] }\end{array}$} & Table 4 & $\begin{array}{l}\text { Sections 6.2.6, 6.2.12, 6.2.13, } \\
6.2 .14,6.2 .15,6.2 .16,6.2 .17 \\
6.2 .85\end{array}$ & No backfill in the emplacement drifts \\
\hline & Section 6.7.2 & Section 6.2.22 & Radionuclide releases through invert \\
\hline & Table 13 & Sections 6.2.1, 6.2.4 & $\begin{array}{l}\text { Tracers and materials left in repository } \\
\text { (non-waste) }\end{array}$ \\
\hline & Table 8 & Section 6.2 .21 & Emplacement pallet requirements \\
\hline $\begin{array}{l}\text { BSC 2004. Repository Subsurface Emplacement } \\
\text { Drift Panel } 2 \text { General Arrangement. } \\
\text { [DIRS 171424] }\end{array}$ & Entire & Section 6.2 .18 & Standoff from emplacement drift \\
\hline \multirow{2}{*}{$\begin{array}{l}\text { BSC 2004. Repository Subsurface Emplacement Drifts } \\
\text { Steel Invert Structure Sect. \& Committed Materials. } \\
\text { [DIRS 169776] }\end{array}$} & Entire & Section 6.2.22 & Composition of the invert \\
\hline & Entire & Section 6.2 .68 & $\begin{array}{l}\text { Lack of cementitious materials in } \\
\text { emplacement drift }\end{array}$ \\
\hline $\begin{array}{l}\text { BSC 2004. Repository Subsurface Turnout } \\
\text { Drift 1-8 Interface. } \\
\text { [DIRS 167736] }\end{array}$ & Entire & Section 6.2 .18 & Standoff from emplacement drift \\
\hline $\begin{array}{l}\text { BSC 2004. Rock Fall on Waste Packages. } \\
\text { [DIRS 167182] }\end{array}$ & Section 6 & Section 6.2 .28 & Effect of rockfall on drip shield \\
\hline $\begin{array}{l}\text { BSC 2004. Saturated Zone Site-Scale Flow Model. } \\
\text { [DIRS 170037] }\end{array}$ & Section 6.4.5.1 & Sections $6.2 .30,6.2 .31$ & Water table rise \\
\hline \multirow{2}{*}{$\begin{array}{l}\text { BSC 2004. Seepage Model for PA Including } \\
\text { Drift Collapse. } \\
\text { [DIRS 167652] }\end{array}$} & Section 6.3.1 & Section 6.2 .18 & No flow lateral boundary condition \\
\hline & Section 6.7 & Section 6.2 .84 & $\begin{array}{l}\text { Anisotropic THM property changes would } \\
\text { increase the likelihood of flow being } \\
\text { diverted around the drift and thus decrease } \\
\text { the potential for seepage }\end{array}$ \\
\hline
\end{tabular}


Table 4-1. Direct Inputs (Continued)

\begin{tabular}{|c|c|c|c|}
\hline Technical Product Input Source Title & Location in Source & Where Used in This Report & Description \\
\hline \multirow{3}{*}{$\begin{array}{l}\text { BSC 2004. Stress Corrosion Cracking of the Drip Shield, } \\
\text { the Waste Package Outer Barrier, and the Stainless } \\
\text { Steel Structural Material. } \\
\text { [DIRS 172203] }\end{array}$} & Sections $1,6.3 .7,6.5 .2, \mathrm{~B} 6.1$ & Section 6.2 .63 & Morphology of SCCs \\
\hline & Section 6.3.7 & Appendix C & Yield strength of Titanium Grade 7 \\
\hline & Section 6.2.1 & $\begin{array}{l}\text { Section 6.2.64; Appendix C, } \\
\text { Section C.1, }\end{array}$ & Damage area susceptible to SCC \\
\hline $\begin{array}{l}\text { BSC 2004. Structural Calculations of Waste Package } \\
\text { Exposed to Vibratory Ground Motion. } \\
\text { [DIRS 167083] }\end{array}$ & Section 6.2.4; Figure 9 & Sections 6.2.9, 6.2.21 & Pallet response to seismic event \\
\hline $\begin{array}{l}\text { BSC 2004. UZ Flow Models and Submodels. } \\
\text { [DIRS 169861] }\end{array}$ & Sections $6.1 .2,6.2 .2, \mathrm{G} 4$ & Sections $6.2 .33,6.2 .86$ & $\begin{array}{l}\text { Episodic infiltration with respect to deep } \\
\text { percolation flow }\end{array}$ \\
\hline $\begin{array}{l}\text { BSC 2004. Waste-Form Features, Events, } \\
\text { and Processes. } \\
\text { [DIRS 170020] }\end{array}$ & $\begin{array}{l}\text { Sections } 6.2 .5,6.2 .12,6.2 .17 \\
6.2 .32,6.2 .37,6.2 .38\end{array}$ & $\begin{array}{l}\text { Sections 6.2.68, 6.2.80, 6.2.81, } \\
6.2 .82\end{array}$ & Reference to several waste form FEPs \\
\hline $\begin{array}{l}\text { BSC 2005. Analysis of Dust Deliquescence for } \\
\text { FEP Screening. } \\
\text { [DIRS 175058] }\end{array}$ & $\begin{array}{l}\text { Sections } 1.1,6.1,6.1 .2 .3,6.2 \\
6.3,6.3 .4,6.4,6.5,7,7.1 .1 \\
\text { 7.1.2, 7.1.3, 7.1.4, 7.1.5; } \\
\text { Appendix E, Section E-1; } \\
\text { Table 7-1 }\end{array}$ & Section 6.2.61 & Dust deliquescence is of low consequence \\
\hline $\begin{array}{l}\text { BSC 2005. DOE and Commercial Waste Package } \\
\text { System Description Document. } \\
\text { [DIRS 174225] }\end{array}$ & Section 4.1.1 & Section 6.2 .43 & $\begin{array}{l}\text { Waste package cylinder contains an } \\
\text { inner concentric cylinder composed of } \\
\text { stainless steel }\end{array}$ \\
\hline \multirow{3}{*}{$\begin{array}{l}\text { BSC 2005. Drift-Scale THC Seepage Model. } \\
\text { [DIRS 172862] }\end{array}$} & Section 6.5 & Section 6.2 .78 & Gas-phase compositions and pressures \\
\hline & Section 6.2.1, 6.4, 6.5.5 & Section 6.2 .60 & Mineral deposition of fractures \\
\hline & Section 6.5 & Section 6.2 .74 & Pressure and gas phase compositions \\
\hline \multirow{3}{*}{$\begin{array}{l}\text { BSC 2005. Drip Shield Structural Response to Rock Fall } \\
\text { Supplemental Calculation. } \\
\text { [DIRS 174052] }\end{array}$} & $\begin{array}{l}\text { Section 7; Figures 7-57, 7-60; } \\
\text { Tables 7-9, 7-35 }\end{array}$ & $\begin{array}{l}\text { Section 6.2.64; Appendix C; } \\
\text { Figure C-1 }\end{array}$ & Drip shield stress calculations \\
\hline & Section 7 ; Figures $7-14$ to $7-19$ & Appendix C & Dent characteristics \\
\hline & Table 7-6 & Section 6.2 .9 & $\begin{array}{l}\text { Drip shield will deflect blocks away from the } \\
\text { waste package }\end{array}$ \\
\hline \multirow[t]{4}{*}{$\begin{array}{l}\text { BSC 2005. EBS Radionuclide Transport Abstraction. } \\
\text { [DIRS 173433] }\end{array}$} & Sections 6.3.4.1.2, 6.3.4.3.5 & Section 6.2 .73 & $\begin{array}{l}\text { Diffusion coefficient for the corrosion } \\
\text { products and waste form domains }\end{array}$ \\
\hline & $\begin{array}{l}\text { Sections 6.3.3, 6.3.4.5, 8.1; } \\
\text { Table 6.3-3 }\end{array}$ & Section 6.2 .63 & $\begin{array}{l}\text { Prediction of crack aperture size } \\
\text { and flow behavior }\end{array}$ \\
\hline & $\begin{array}{l}\text { Sections } 6.3,6.3 .1 .1,6.5 \\
\text { Figure } 6.3-1\end{array}$ & Section 6.2 .40 & Flow in EBS \\
\hline & Sections 6.3.4.3.3, 6.3.4.3.5 & Section 6.2 .73 & Surface area uncertainty parameter \\
\hline
\end{tabular}


Table 4-1. Direct Inputs (Continued)

\begin{tabular}{|c|c|c|c|}
\hline Technical Product Input Source Title & Location in Source & Where Used in This Report & Description \\
\hline $\begin{array}{l}\text { BSC 2005. EBS Radionuclide Transport Abstraction. } \\
\text { [DIRS 173433] }\end{array}$ & $\begin{array}{l}\text { Section 6.3.4.1; } \\
\text { Equation 6.3.4.1.1-23 }\end{array}$ & Section 6.2 .22 & $\begin{array}{l}\text { Effect of variable porosity on the invert } \\
\text { diffusion coefficient }\end{array}$ \\
\hline \multirow[t]{9}{*}{ (Continued) } & Sections 8 & Section 6.2 .24 & Effect of variable porosity on invert \\
\hline & Section 6.3.4 & Section 6.2 .44 & $\begin{array}{l}\text { Radionuclide transport internal to } \\
\text { waste package }\end{array}$ \\
\hline & Section 6.6.1 & Section 6.2 .86 & Reference to "bathtub effect" \\
\hline & Section 6.5.3.6; Figure 7.3-1 & Section 6.2 .88 & Drift shadow effect \\
\hline & Section 6.3.4.1.1 & Section 6.2 .47 & $\begin{array}{l}\text { Corrosion products created by the } \\
\text { degradation of the invert steel could enter } \\
\text { the pore space of the invert ballast and alter } \\
\text { its porosity }\end{array}$ \\
\hline & Section 6.3.4.4 & Section 6.2 .53 & Water movement in EBS \\
\hline & Sections $6.1,6.3 .1 .1,6.6 .1$ & Section 6.2 .86 & Water movement in EBS \\
\hline & Section 6.4.1 & Section 6.2 .73 & $\begin{array}{l}\text { Soret effect considered to be negligible and } \\
\text { is not modeled }\end{array}$ \\
\hline & Section 8 & Section 6.2 .37 & $\begin{array}{l}\text { RTA model is implemented directly into the } \\
\text { TSPA-LA GoldSim model }\end{array}$ \\
\hline \multirow{9}{*}{$\begin{array}{l}\text { BSC 2005. Engineered Barrier System: Physical and } \\
\text { Chemical Environment. } \\
\text { [DIRS 175083] }\end{array}$} & Sections 6.8 & Section 6.2 .18 & $\begin{array}{l}\text { Chemical effects of rock } \\
\text { reinforcement material }\end{array}$ \\
\hline & Sections 6.4.1, 8.1 & Section 6.2 .23 & $\begin{array}{l}\text { Chemical degradation of waste } \\
\text { emplacement pallet }\end{array}$ \\
\hline & Section 6.7 & Section 6.2 .24 & Consumption of oxygen \\
\hline & Section 6.7.1 & Sections $6.2 .76,6.2 .80$ & Redox potential \\
\hline & Figure $6.7-5$ & Sections $6.2 .74,6.2 .78$ & Reference to start of thermal period \\
\hline & Sections $6.3,6.5,6.7,6.8$ & Section 6.2 .60 & One-way coupled processes \\
\hline & Section 6.7.1 & Sections $6.2 .78,6.2 .79$ & Values of oxygen flux in/out of drift \\
\hline & Section 6.4.2; Figure 6.4-3 & Section 6.2 .47 & Redox potential \\
\hline & Section 6.7.1; Figure 6.7-1 & Section 6.2 .74 & Reduction of oxygen level \\
\hline \multirow{2}{*}{$\begin{array}{l}\text { BSC 2005. Features, Events, and Processes in UZ Flow } \\
\text { and Transport. } \\
\text { [DIRS 174191] }\end{array}$} & Sections $6.2 .35,6.7 .3$ & Section 6.2 .78 & $\begin{array}{l}\text { Reference to FEPs 2.2.10.10.0A } \\
\text { and 2.2.11.03.0A }\end{array}$ \\
\hline & Section 6.9.7 & Section 6.2 .18 & $\begin{array}{l}\text { Details regarding the impact of an } \\
\text { alkaline plume }\end{array}$ \\
\hline
\end{tabular}


Table 4-1. Direct Inputs (Continued)

\begin{tabular}{|c|c|c|c|}
\hline Technical Product Input Source Title & Location in Source & Where Used in This Report & Description \\
\hline \multirow{4}{*}{$\begin{array}{l}\text { BSC 2005. IED Interlocking Drip Shield and } \\
\text { Emplacement Pallet [Sheet } 1 \text { of 1]. } \\
\text { [DIRS 173303] }\end{array}$} & Table 6 & Section 6.2 .23 & Pallet tube construction \\
\hline & Entire & Sections $6.2 .44,6.2 .76$ & $\begin{array}{l}\text { Waste package and drip shield general } \\
\text { corrosion rates and drip shield thickness }\end{array}$ \\
\hline & Section 6.5.6 & Section 6.2 .64 & Drip shield welding treatment \\
\hline & Table labeled "Directory" & Section 6.2 .32 & Overlap between adjacent drip shields \\
\hline \multirow{4}{*}{$\begin{array}{l}\text { BSC 2005. IED Subsurface Facilities Committed } \\
\text { Materials [Sheet } 1 \text { of 1]. } \\
\text { [DIRS 173871] }\end{array}$} & Entire & Sections $6.2 .23,6.2 .26$ & Pallet materials \\
\hline & Entire & $\begin{array}{l}\text { Sections } 6.2 .1,6.2 .4,6.2 .6 \\
6.2 .12,6.2 .13,6.2 .14,6.2 .15 \\
6.2 .16,6.2 .17,6.2 .28,6.2 .29 \\
6.2 .85\end{array}$ & $\begin{array}{l}\text { Summary of materials planned to } \\
\text { be installed }\end{array}$ \\
\hline & Entire & Section 6.2 .18 & Cementitious materials used in the drift \\
\hline & Entire & Section 6.2 .68 & $\begin{array}{l}\text { No cementitious materials in the } \\
\text { emplacement drifts }\end{array}$ \\
\hline $\begin{array}{l}\text { BSC 2005. IED Subsurface Facilities Ground Support } \\
\text { Configuration [Sheet } 1 \text { of 1]. } \\
\text { [DIRS 173498] }\end{array}$ & Entire & Sections $6.2 .28,6.2 .29$ & $\begin{array}{l}\text { Ground support structure will be fabricated } \\
\text { of stainless steel for longevity }\end{array}$ \\
\hline \multicolumn{2}{|c|}{ BSC 2005. IED Waste Package Configuration [Sheet 1 of Table 1} & Sections $6.2 .44,6.2 .76$ & Waste package component assembly \\
\hline \multirow{2}{*}{ [DIRS 173501] } & Entire & Section 6.2 .43 & Minimum waste package length \\
\hline & Table 1 & Section 6.2 .43 & $\begin{array}{l}\text { Waste package contains an inner } \\
\text { concentric cylinder of stainless steel }\end{array}$ \\
\hline $\begin{array}{l}\text { BSC 2005. IED Waste Package Decay Heat Generation } \\
\text { [Sheet } 1 \text { of 1]. } \\
\text { [DIRS 173705] }\end{array}$ & Table 1 & Section 6.2 .68 & Heat generation output \\
\hline $\begin{array}{l}\text { BSC 2005. IED Waste Package Processes, Ground } \\
\text { Motion Time Histories, and Testing and Materials } \\
\text { [Sheet } 1 \text { of 1]. } \\
\text { [DIRS 173627] }\end{array}$ & Entire & Section 6.2 .69 & Waste package design for barrier gap size \\
\hline $\begin{array}{l}\text { BSC 2005. IED Waste Package Radiation } \\
\text { Characteristics [Sheet } 1 \text { of 1]. } \\
\text { [DIRS 173426] }\end{array}$ & Figure 3 & Section 6.2 .81 & Radiation level \\
\hline \multirow{2}{*}{$\begin{array}{l}\text { BSC 2005. In-Package Chemistry Abstraction. } \\
\text { [DIRS 174583] }\end{array}$} & Appendix B, Section B.6 & Section 6.2 .81 & $\mathrm{pH}$ levels in EBS components \\
\hline & Table 4-8 & Section 6.2 .23 & Stainless steel corrosion \\
\hline $\begin{array}{l}\text { BSC 2005. Mechanical Assessment of the Waste } \\
\text { Package Subject to Vibratory Ground Motion. } \\
\text { [DIRS 173172] }\end{array}$ & Sections XI, XI-2.3, XI-4 & Section 6.2.21, 6.2.23 & $\begin{array}{l}\text { Structural performance of connector tubes } \\
\text { during a seismic event }\end{array}$ \\
\hline
\end{tabular}


Table 4-1. Direct Inputs (Continued)

\begin{tabular}{|c|c|c|c|}
\hline Technical Product Input Source Title & Location in Source & Where Used in This Report & Description \\
\hline \multirow{6}{*}{$\begin{array}{l}\text { BSC 2005. Multiscale Thermohydrologic Model. } \\
\text { [DIRS 173944] }\end{array}$} & Section 6.3.11 & Section 6.2.22 & Hydrologic properties of invert \\
\hline & Section 6.3.7, 6.3.7.1 & Section 6.2 .90 & Influence of collapsed drift \\
\hline & Section 6.3.11; Table 6.3-45 & Section 6.2 .43 & $\begin{array}{l}\text { Temperatures at crown of drip shield and } \\
\text { top of invert; Water vapor partial pressure. }\end{array}$ \\
\hline & Section 6.3.3 & Section 6.2 .40 & Saturations in the invert \\
\hline & Section 6.3.9 & Section 6.2 .42 & $\begin{array}{l}\text { Saturation of the repository in the heavily } \\
\text { fractured Topopah Spring Tuff }\end{array}$ \\
\hline & Tables 6.3-5, 6.3-6, 6.3-25 & Section 6.2 .33 & $\begin{array}{l}\text { Effect of infiltration flux on peak postclosure } \\
\text { drift wall temperature }\end{array}$ \\
\hline $\begin{array}{l}\text { BSC 2005. Q-List. } \\
\text { [DIRS 174269] }\end{array}$ & Appendix A & Section 6.2 .23 & List of items ITWI \\
\hline $\begin{array}{l}\text { BSC 2005. Screening Analysis of Criticality Features, } \\
\text { Events, and Processes for License Application. } \\
\text { [DIRS 173869] }\end{array}$ & Table 7.2-1 & Section 6.2 .81 & $\begin{array}{l}\text { No criticality events are expected to occur } \\
\text { in the repository }\end{array}$ \\
\hline \multirow{7}{*}{$\begin{array}{l}\text { BSC 2005. Screening of Features, Events, } \\
\text { and Processes in Drip Shield and Waste } \\
\text { Package Degradation. } \\
\text { [DIRS 174995] }\end{array}$} & Sections $6.2 .8,6.2 .9,6.2 .30$ & Sections $6.2 .76,6.2 .82$ & $\begin{array}{l}\text { Hydride cracking (reference to FEP } \\
\text { discussion only) }\end{array}$ \\
\hline & Section 6.2 .14 & Sections 6.2.9, 6.2.69 & Deflection due to rockfall \\
\hline & Section 6.2.4 & Section 6.2 .63 & Stress corrosion cracking in waste package \\
\hline & Section $6.2 .31,6.2 .32$ & Sections $6.2 .81,6.2 .82$ & $\begin{array}{l}\text { Radiation levels and their potential to } \\
\text { damage EBS components }\end{array}$ \\
\hline & Section 6.2.1 & Section 6.2.5 & $\begin{array}{l}\text { Consequences of a potential error in waste } \\
\text { or drip shield emplacement }\end{array}$ \\
\hline & Sections 6.2.6, 6.2.7 & Sections $6.2 .44,6.2 .62$ & $\begin{array}{l}\text { Localized corrosion of the drip shield and } \\
\text { waste package }\end{array}$ \\
\hline & Section 6.2 .5 & 6.2 .64 & $\begin{array}{l}\text { Stress corrosion cracks are of low } \\
\text { consequence }\end{array}$ \\
\hline \multirow[t]{5}{*}{$\begin{array}{l}\text { BSC 2005. Seismic Consequence Abstraction. } \\
\text { [DIRS 173247] }\end{array}$} & $\begin{array}{l}\text { Sections } 6,6.3 .3,6.4 .3,6.5 .5 \\
6.6 .1,6.8 .2,6.9 .2,8\end{array}$ & Sections 6.2.9, 6.2.10, 6.2.90 & $\begin{array}{l}\text { Seismic damage to EBS components due } \\
\text { to large rockfall }\end{array}$ \\
\hline & $\begin{array}{l}\text { Sections 6.3.1, 6.5.1, 6.5.2, } \\
\text { 6.5.3, 6.5.6.3; Table 6.5-16 }\end{array}$ & Section 6.2 .80 & $\begin{array}{l}\text { Seismic damage to waste package } \\
\text { and cladding }\end{array}$ \\
\hline & Section 6.5 .5 & Section 6.2 .80 & Drip shield endurance during seismic event \\
\hline & Section 6.3 .2 & Section 6.2 .63 & Initiation of SCCs \\
\hline & Section 6.5 & Section 6.2 .43 & $\begin{array}{l}\text { Potential earthquake vibratory ground } \\
\text { motion might damage waste packages }\end{array}$ \\
\hline
\end{tabular}




\begin{tabular}{|c|c|c|c|}
\hline Technical Product Input Source Title & Location in Source & Where Used in This Report & Description \\
\hline $\begin{array}{l}\text { BSC 2005. Seismic Consequence Abstraction. } \\
\text { [DIRS 173247] }\end{array}$ & $\begin{array}{l}\text { Sections 6.6.2, 6.6.2.1, 6.6.2.2, } \\
6.8 .1\end{array}$ & Section 6.2 .10 & $\begin{array}{l}\text { Lithophysal and non-lithophysal rockfall and } \\
\text { load }\end{array}$ \\
\hline \multirow[t]{3}{*}{ (Continued) } & Section 6.6.2 & Appendix C, Section C.1 & $\begin{array}{l}\text { Drip shield damage from rockfall in } \\
\text { lithophysal units }\end{array}$ \\
\hline & $\begin{array}{l}\text { Sections } 6.3 .3,6.5 .5,6.6 .1 .2 \\
6.6 .2 .1,6.6 .3 ; \text { Table } 6.6-2\end{array}$ & Section 6.2.9 & Response of drip shield to seismic event \\
\hline & Section 6.5.5 & Section 6.2.9 & Basis for exclusion of drip shield separation \\
\hline \multirow[t]{10}{*}{$\begin{array}{l}\text { BSC 2005. Subsurface Facility Description Document. } \\
\text { [DIRS 174514] }\end{array}$} & $\begin{array}{l}\text { Sections 2.3.2, 3.1.1.10.16, } \\
\text { 3.1.1.16.1, 4.1.1.2 }\end{array}$ & Sections $6.2 .28,6.2 .29$ & $\begin{array}{l}\text { Requirements and function of ground } \\
\text { support; subsurface development overview }\end{array}$ \\
\hline & $\begin{array}{l}\text { Sections 2.3.2, 3.1.1.15.1, } \\
\text { 3.2.4.10, 4.1.1.1, 4.1.1.3, } \\
\text { 4.1.1.3.6.1; Figure 4-5 }\end{array}$ & $\begin{array}{l}\text { Sections } 6.2 .1,6.2 .2,6.2 .4 \\
6.2 .18,6.2 .47\end{array}$ & $\begin{array}{l}\text { Excavation methods; control of materials } \\
\text { during construction; Dryout of repository } \\
\text { during ventilation }\end{array}$ \\
\hline & Figure 4-10 & Section 6.2 .80 & Configuration of the drip shield \\
\hline & Figure 4-10 & Section 6.2 .85 & No backfill in emplacement drifts \\
\hline & Sections 2.2, 4.1.1.3.6.4 & Section 6.2 .82 & $\begin{array}{l}\text { Closure of the repository } \\
\text { subsurface facilities }\end{array}$ \\
\hline & Section 4.1.1.3.6.3 & Section 6.2.6 & Backfill in nonemplacement openings only \\
\hline & $\begin{array}{l}\text { Sections 3.1.1.10.6, 3.1.1.13.7, } \\
4.1 .1 .2\end{array}$ & Sections $6.2 .1,6.2 .5,6.2 .42$ & $\begin{array}{l}\text { Repository designed with a gradient and } \\
\text { has standoff above water table, has } \\
\text { standoffs from faults, }\end{array}$ \\
\hline & Figures 4-7, 4-10 & Sections $6.2 .23,6.2 .69$ & $\begin{array}{l}\text { Waste package pallet material } \\
\text { and configuration }\end{array}$ \\
\hline & Section 3.1.1.10.13 & Section 6.2 .22 & Support and other functional requirement \\
\hline & Section 4.1.1 & Section 6.2.5 & Waste emplacement description \\
\hline \multirow{4}{*}{$\begin{array}{l}\text { BSC 2005. Waste Form and In-Drift } \\
\text { Colloids-Associated Radionuclide Concentrations: } \\
\text { Abstraction and Summary. } \\
\text { [DIRS 174290] }\end{array}$} & Sections 6.3.1, 6.5.2.1, 7.2 & Section 6.2 .53 & Colloid formation \\
\hline & $\begin{array}{l}\text { Sections 6.3.1, 6.3.2, 6.3.3, } \\
\text { 6.3.3.1 } \\
\end{array}$ & Section 6.2 .56 & Colloid sorption processes \\
\hline & Section 7.2 & Sections 6.2 .55 & Filtration and sorption of colloids in EBS \\
\hline & Section 7.2 & Section 6.2 .59 & Colloid formation \\
\hline $\begin{array}{l}\text { Canori, G.F. and Leitner, M.M. } 2003 . \\
\text { Project Requirements Document. } \\
\text { [DIRS 166275] }\end{array}$ & p. 3-95 & Section 6.2 .68 & Exothermic reaction in the EBS \\
\hline
\end{tabular}


Table 4-1. Direct Inputs (Continued)

\begin{tabular}{|c|c|c|c|}
\hline Technical Product Input Source Title & Location in Source & Where Used in This Report & Description \\
\hline $\begin{array}{l}\text { Christensen, H. and Sunder, S. 2000. "Current State of } \\
\text { Knowledge of Water Radiolysis Effects on Spent Nuclear } \\
\text { Fuel Corrosion." } \\
\text { [DIRS 162387] }\end{array}$ & pp. 102 to 108 & Section 6.2 .81 & Effects of radiolysis on chemistry \\
\hline $\begin{array}{l}\text { Craig, R.W. 2001. "Transmittal of Level } 5 \text { Deliverable } \\
\text { SPW205M5, 'Excavation-Induced Fracture Study."” } \\
\text { [DIRS 171411] }\end{array}$ & pp. 1 to $5,7,16$ & $\begin{array}{l}\text { Sections } 4.1 .2,6.2 .2 \text {; } \\
\text { Appendix B, Sections B.2, B.3, } \\
\text { B.4 }\end{array}$ & $\begin{array}{l}\text { Tunnel boring machine; mapping and } \\
\text { observations in the tunnel }\end{array}$ \\
\hline $\begin{array}{l}\text { CRWMS M\&O 2000. Water Pooling-Evaporation in a } \\
\text { Waste Package. } \\
\text { [DIRS 149626] }\end{array}$ & Section 6 & Section 6.2 .63 & $\begin{array}{l}\text { Vapor pressure inside a breached } \\
\text { waste package }\end{array}$ \\
\hline \multirow{2}{*}{$\begin{array}{l}\text { CRWMS M\&O 2001. Water Distribution and } \\
\text { Removal Model. } \\
\text { [DIRS 152016] }\end{array}$} & $\begin{array}{l}\text { Sections 6.1.1.2, 6.1.4; } \\
\text { Table 6-1 }\end{array}$ & $\begin{array}{l}\text { Sections } 6.2 .63,6.2 .64 \\
\text { Appendix A }\end{array}$ & $\begin{array}{l}\text { Capillary holding capacity. Impact of drop } \\
\text { on saturated SCC }\end{array}$ \\
\hline & Equations 6.9, 6.10; Table 6-1 & Section 6.2 .63 & Water retention \\
\hline $\begin{array}{l}\text { Dean, J.A. 1992. Lange's Handbook of Chemistry. } \\
\text { [DIRS 100722] }\end{array}$ & Table 4.16 & Section 6.2 .79 & $\begin{array}{l}\text { Half-life of Argon, Krypton, Radon, Xenon } \\
\text { and Tritium }\end{array}$ \\
\hline $\begin{array}{l}\text { Glass, R.S.; Overturf, G.E.; Van Konynenburg, R.A.; and } \\
\text { McCright, R.D. 1986. "Gamma Radiation Effects on } \\
\text { Corrosion-I. Electrochemical Mechanisms for the } \\
\text { Aqueous Corrosion Processes of Austenitic Stainless } \\
\text { Steels Relevant to Nuclear Waste Disposal in Tuff." } \\
\text { [DIRS } 105021\end{array}$ & pp. 577 to 590 & Section 6.2 .80 & Hydrogen generation due to radiolysis \\
\hline $\begin{array}{l}\text { Green, R.T.; Evans, D.D.; and Filippone, W.L. } 1987 . \\
\text { “Effect of Electric Fields on Vapor Transport Near a High- } \\
\text { Level Waste Canister.” } \\
\text { [DIRS 170174] }\end{array}$ & Chapter 32 & Appendix A & Electron field effects on coupled processes \\
\hline $\begin{array}{l}\text { Hirschfelder, J.O.; Curtiss, C.F.; and Bird, R.B } 1964 . \\
\text { Molecular Theory of Gases and Liquids. } \\
\text { [DIRS 171800] }\end{array}$ & p. 8 & $\begin{array}{l}\text { Sections 6.2.60, 6.2.73; } \\
\text { Appendix A }\end{array}$ & $\begin{array}{l}\text { Discussion of the Soret effect on } \\
\text { mass transfer }\end{array}$ \\
\hline $\begin{array}{l}\text { Howard, C.L.; Finley, R.L.; Johnston, R.L.; Taylor, R.S.; } \\
\text { George, J.T.; Lowry, W.E.; and Mason, N.G. 2001. } \\
\text { Engineered Barrier System—Pilot Scale Test \#3, Heated } \\
\text { Drip Shield Test Results. } \\
\text { [DIRS 153282] }\end{array}$ & Sections $4.3,5$ & Section 6.2 .43 & Moisture in the invert \\
\hline \multirow{2}{*}{$\begin{array}{l}\text { LB0302DSCPTHCS.002. Drift-Scale Coupled Processes } \\
\text { (THC Seepage) Model: Data Summary. } \\
\text { [DIRS 161976] }\end{array}$} & thc6_wn_drift_r.xls & Section 6.2 .74 & $\begin{array}{l}\text { Reduction of oxygen due to alter } \\
\text { vapor generation }\end{array}$ \\
\hline & thc6 & Section 6.2 .78 & sure \\
\hline
\end{tabular}


Table 4-1. Direct Inputs (Continued)

\begin{tabular}{|c|c|c|c|}
\hline Technical Product Input Source Title & Location in Source & Where Used in This Report & Description \\
\hline $\begin{array}{l}\text { McCright, R.D.; Halsey, W.G.; and Van Konynenburg, } \\
\text { R.A. 1987. Progress Report on the Results of Testing } \\
\text { Advanced Conceptual Design Metal Barrier Materials } \\
\text { Under Relevant Environmental Conditions for a } \\
\text { Tuff Repository. } \\
\text { [DIRS 159336] }\end{array}$ & Table 6 & Section 6.2.23; Table 6-1 & Corrosion of alloy materials \\
\hline $\begin{array}{l}\text { MO0407SPAPCEML.005. EBS P\&CE Model Longevity o } \\
\text { Materials Evaluation. } \\
\text { [DIRS 172097] }\end{array}$ & fWorksheet "316” & Section 6.2 .23 & Rate of stainless steel degradation \\
\hline \multirow[t]{2}{*}{$\begin{array}{l}\text { MO0408MWDDDMIO.002. Drift Degradation Model } \\
\text { Inputs and Outputs. } \\
\text { [DIRS 171483] }\end{array}$} & $\begin{array}{l}\text { Excel files: nonlith rockfall } \\
\text { characteristics in emplacement } \\
\text { drifts with 1e-4 gm.xls, nonlith } \\
\text { rockfall characteristics in } \\
\text { emplacement drifts with 1e-5 } \\
\text { gm.xls }\end{array}$ & Table C-1 & $\begin{array}{l}\text { Rockfall impact data as a function of annual } \\
\text { exceedance frequency }\end{array}$ \\
\hline & $\begin{array}{l}\text { Excel files: nonlith rockfall } \\
\text { characteristics in emplacement } \\
\text { drifts with 1e-6 gm.xls, nonlith } \\
\text { rockfall characteristics in } \\
\text { emplacement drifts with 1e-7 } \\
\text { gm.xls }\end{array}$ & Table C-1 & $\begin{array}{l}\text { Rockfall impact data as a function of annual } \\
\text { exceedance frequency }\end{array}$ \\
\hline $\begin{array}{l}\text { MO0501BPVELEMP.001. Bounded Horizontal Peak } \\
\text { Ground Velocity Hazard at the Repository Waste } \\
\text { Emplacement Level. } \\
\text { [DIRS 172682] }\end{array}$ & Entire & Appendix C, Section C.2.3 & Bounded hazard curve \\
\hline $\begin{array}{l}\text { MO0501SEPFEPLA.001. LA FEP List and Screening. } \\
\text { [DIRS 172601] }\end{array}$ & $\begin{array}{l}\text { File FEPS_be.mdb, table } \\
\text { "FEPS" }\end{array}$ & $\begin{array}{l}\text { Sections 1.2, 4.1.1, 6.1.1, } \\
6.1 .5,7.1 .1 ; \text { Tables 1-1, 6-1 }\end{array}$ & LA FEP list \\
\hline $\begin{array}{l}\text { NRC (U.S. Nuclear Regulatory Commission) } 2003 . \\
\text { Yucca Mountain Review Plan, Final Report. } \\
\text { [DIRS 163274] }\end{array}$ & $\begin{array}{l}\text { Sections } 2.2 .1,2.2 .1 .2 \\
2.2 .1 .2 .1 .3,2.2 .1 .3 .3 .3\end{array}$ & $\begin{array}{l}\text { Sections } 1,4.2,4.2 .2,4.2 .2 .1 \\
4.2 .2 .2,4.2 .3,6.1 .1,6.1 .2,7.1 \\
7.1 .2\end{array}$ & Regulatory acceptance criteria \\
\hline $\begin{array}{l}\text { Sargent G. and Conrad H. 1969. "Stress Relaxation and } \\
\text { Thermally Activated Deformation in Titanium." } \\
\text { [DIRS 174054] }\end{array}$ & Figure 3 & $\begin{array}{l}\text { Section 6.2.64; Appendix A, } \\
\text { Appendix C }\end{array}$ & $\begin{array}{l}\text { Titanium exhibits rapid room temperature } \\
\text { stress relaxation }\end{array}$ \\
\hline
\end{tabular}


Table 4-1. Direct Inputs (Continued)

\begin{tabular}{|c|c|c|c|}
\hline Technical Product Input Source Title & Location in Source & Where Used in This Report & Description \\
\hline $\begin{array}{l}\text { SN0506F4104405.003. Analyses of Phase I and Phase II } \\
\text { Data from the Stress Corrosion Crack Flow Tests (Data } \\
\text { from 1/12/2005 to 5/13/2005). } \\
\text { [DIRS 174472] }\end{array}$ & $\begin{array}{l}\text { SCC_Phasell_Test_ } \\
\text { Preliminary_Summary_ } \\
\text { 6-8-05.doc }\end{array}$ & Section 6.2 .64 & $\begin{array}{l}\text { Tests for potential for water flow } \\
\text { through cracks }\end{array}$ \\
\hline $\begin{array}{l}\text { Stumm, W. and Morgan, J.J. 1996. Aquatic Chemistry, } \\
\text { Chemical Equilibria and Rates in Natural Waters. } \\
\text { [DIRS 125332] }\end{array}$ & Section 4.3, p. 161 & Section 6.2.43; Appendix A & $\begin{array}{l}\mathrm{pH} \text { of rainwater as an analogue } \\
\text { to condensation }\end{array}$ \\
\hline $\begin{array}{l}\text { Tang, J.S. 2003. Technical Report of Calculations } \\
\text { Supporting Evaluation of Radiation Effects. } \\
\text { [DIRS 164012] }\end{array}$ & Table 4-7 & Section 6.2 .81 & Neutron irradiation is negligible \\
\hline $\begin{array}{l}\text { Wan, J. and Wilson, J.L. 1994. "Colloid Transport in } \\
\text { Unsaturated Porous Media." } \\
\text { [DIRS 114430] }\end{array}$ & pp. 857 to 864 & Section 6.2.57; Appendix A & $\begin{array}{l}\text { Hydrophylic and hydrophobic behavior } \\
\text { of colloids }\end{array}$ \\
\hline $\begin{array}{l}\text { Weast, R.C., ed. 1985. CRC Handbook of Chemistry and } \\
\text { Physics. 66th Edition. Boca Raton, Florida: CRC Press. } \\
\text { TIC: } 216054 . \\
\text { [DIRS 111561] }\end{array}$ & p. F-10 & Section 6.2 .78 & Density of air \\
\hline $\begin{array}{l}\text { Wu, Y-S.; Zhang, W.; Pan, L.; Hinds, J.; and Bodvarsson, } \\
\text { G.S. 2000. Capillary Barriers in Unsaturated Fractured } \\
\text { Rocks of Yucca Mountain, Nevada. } \\
\text { [DIRS 154918] }\end{array}$ & , Section 4.1; Figure 4.1-11 & $\begin{array}{l}\text { Sections } 6.2 .33,6.2 .86 \\
\text { Appendix A }\end{array}$ & $\begin{array}{l}\text { Episodic infiltration on deep percolation } \\
\text { below the PTn }\end{array}$ \\
\hline
\end{tabular}

NOTE: $\quad$ Technical Management Review Board (TMRB) Decision Proposal (BSC 2005 [DIRS 174640]) authorizes citation of all design documents in this table as direct inputs. 


\subsubsection{Background, Technical Information Sources, and Literature Searches}

The sources of technical information used for the FEPs evaluations are cited within each of the individual FEPs discussions, and use of this information and data has been referenced.

Where possible, the technical information used in this report to support the screening decisions has been obtained from controlled source documents and references using the appropriate document identifiers or records system accession numbers. Sources of such information include, but are not limited to, YMP analysis reports or model reports, technical reports, and other documents and databases. As needed, alternative and corroborative information and data were obtained from literature searches of peer-reviewed journals, other widely recognized scientific periodicals, results of review of YMP documents by external organizations, and other appropriate sources such as technical handbooks and textbooks. Justification for use of external sources for direct input is provided in Appendix A, and qualification of the study by Craig (2001 [DIRS 171411]), a direct input to Section 6.2.2, is located in Appendix B.

\subsection{CRITERIA}

Criteria relevant to the FEP screening process are discussed in this section. These criteria stem from applicable regulations at 10 CFR Part 63 [DIRS 173273], and the TWP (BSC 2005 [DIRS 173694], Section 3). These criteria find expression as specific acceptance criteria presented by the NRC in the YMRP (NRC 2003 [DIRS 163274], Sections 2.2.1.2.3 and 2.2.1.3.3.3).

\subsubsection{Project Requirements Document}

The TWP (BSC 2005 [DIRS 173694], Section 3.2) presents regulatory criteria that are relevant to developing and screening FEPs. The regulatory requirements include criteria relevant to performance assessment activities, in general, and to FEP-related activities as they pertain to performance assessment, in particular. The criteria pertaining specifically to the evaluation of FEPs are summarized below in Table 4-2.

\subsubsection{Yucca Mountain Review Plan}

As described in the TWP (BSC 2005 [DIRS 173694], Section 3.2), the acceptance criteria listed in the YMRP that are relevant to this document are contained in YMRP Section 2.2.1.2.1.3, under the title of "Scenario Analysis and Event Probability" (NRC 2003 [DIRS 163274]), and in YMRP Section 2.2.1.3.3.3 (NRC 2003 [DIRS 163274]) under the title "Quantity and Chemistry of Water Contacting Waste Packages and Waste Forms." These criteria relate to the identification of FEPs and the associated screening process. Criteria identified as relevant to this document are listed below. Section 7.1 summarizes how the EBS FEPs document addresses the applicable acceptance criteria. 
Table 4-2. Applicable Regulatory Requirements

\begin{tabular}{|c|c|}
\hline Description of Applicable Requirement or Criteria & $\begin{array}{l}10 \text { CFR } 63 \text { (NRC } \\
\text { Regulations) }\end{array}$ \\
\hline \multicolumn{2}{|l|}{ General Requirements and Scope Pertinent to FEPs Screening } \\
\hline General requirements pertaining to providing a performance assessment. & $\begin{array}{l}63.2 \\
63.114\end{array}$ \\
\hline $\begin{array}{l}\text { Include data related to geology, hydrology, and geochemistry (including disruptive processes } \\
\text { and events) to the extent necessary. }\end{array}$ & 63.114(a) \\
\hline $\begin{array}{l}\text { Include information of the design of the engineered barrier system used to define parameters } \\
\text { and conceptual models. }\end{array}$ & 63.114(a) \\
\hline $\begin{array}{l}\text { Account for uncertainties and variabilities in parameter values and provide the technical basis } \\
\text { for parameter ranges, probability distributions, or bounding values. }\end{array}$ & $\begin{array}{l}63.114(b) \\
63.304(4)\end{array}$ \\
\hline \multicolumn{2}{|l|}{ FEPs Specific Criteria } \\
\hline Consider only events that have at least one chance in 10,000 of occurring over 10,000 years. & $63.114(d)$ \\
\hline $\begin{array}{l}\text { Provide the technical basis for either inclusion or exclusion of FEPs. Provide the justification } \\
\text { and technical basis for those excluded based on probability. Not to include any unlikely FEPs } \\
\text { for the human-intrusion and groundwater protection standards. }\end{array}$ & $\begin{array}{l}63.114(d) \\
63.342\end{array}$ \\
\hline $\begin{array}{l}\text { Provide technical basis for either the inclusion or exclusion of features, events, and } \\
\text { processes. Need not be evaluated in detail if results of the performance assessment would } \\
\text { not be significantly changed. }\end{array}$ & 63.114(e and f) \\
\hline
\end{tabular}

\subsubsection{Acceptance Criteria from Yucca Mountain Review Plan, Final Report (NRC 2003 [DIRS 163274]), Section 2.2.1.2.1.3: Scenario Analysis and Event Probability}

These acceptance criteria are based on meeting the requirements of 10 CFR 63.114(e) and (f) (NRC 2003 [DIRS 163274], Section 2.2.1.2.1.3):

Acceptance Criterion 1: The Identification of a List of Features, Events, and Processes Is Adequate.

(1) The Safety Analysis Report contains a complete list of features, events, and processes, related to the geologic setting or the degradation, deterioration, or alteration of engineered barriers (including those processes that would affect the performance of natural barriers), that have the potential to influence repository performance. The list is consistent with the site characterization data. Moreover, the comprehensive features, events, and processes list includes, but is not limited to, potentially disruptive events related to igneous activity (extrusive and intrusive); seismic shaking (high-frequency-low magnitude, and rare large-magnitude events); tectonic evolution (slip on existing faults and formation of new faults); climatic change (change to pluvial conditions); and criticality.

Acceptance Criterion 2: Screening of the List of Features, Events, and Processes Is Appropriate.

(1) The U.S. Department of Energy has identified all features, events, and processes related to either the geologic setting or to the degradation, deterioration, or alteration of engineered barriers (including those processes that would affect the performance of natural barriers) that have been excluded; 
(2) The U.S. Department of Energy has provided justification for those features, events, and processes that have been excluded. An acceptable justification for excluding features, events, and processes is that either the feature, event, and process is specifically excluded by regulation; probability of the feature, event, and process (generally an event) falls below the regulatory criterion; or omission of the feature, event, and process does not significantly change the magnitude and time of the resulting radiological exposures to the reasonably maximally exposed individual, or radionuclide releases to the accessible environment; and

(3) The U.S. Department of Energy has provided an adequate technical basis for each feature, event, and process, excluded from the performance assessment, to support the conclusion that either the feature, event, or process is specifically excluded by regulation; the probability of the feature, event, and process falls below the regulatory criterion; or omission of the feature, event, and process does not significantly change the magnitude and time of the resulting radiological exposures to the reasonably maximally exposed individual, or radionuclide releases to the accessible environment.

\subsubsection{Acceptance Criteria from Yucca Mountain Review Plan, Final Report (NRC 2003 [DIRS 163274]) from Section 2.2.1.3.3.3: Quantity and Chemistry of Water Contacting Engineered Barriers and Waste Forms}

The criteria listed below are appropriate to be addressed by this report, as these criteria deal with the quantity and chemistry of water contacting the EBS, which is a fundamental topic that incorporates many of the design features and conditions of the EBS. These acceptance criteria are based on meeting the requirements of 10 CFR 63.114(a)-(c) and (e)-(g) (NRC 2003 [DIRS 163274], Section 2.2.1.3.3.3).

Acceptance Criterion 1: System Description and Model Integration Are Adequate.

(1) Total system performance assessment adequately incorporates important design features, physical phenomena, and couplings, and uses consistent and appropriate assumptions throughout the quantity and chemistry of water contacting engineered barriers and waste forms abstraction process;

(2) The abstraction of the quantity and chemistry of water contacting engineered barriers and waste forms uses assumptions, technical bases, data, and models that are appropriate and consistent with other related Department of Energy abstractions. For example, the assumptions used for the quantity and chemistry of water contacting engineered barriers and waste forms are consistent with the abstractions of "Degradation of Engineered Barriers" (Section 2.2.1.3.1); "Mechanical Disruption of Engineered Barriers" (Section 2.2.1.3.2); "Radionuclide Release Rates and Solubility Limits" (Section 2.2.1.3.4); "Climate and Infiltration" (Section 2.2.1.3.5); and "Flow Paths in the Unsaturated Zone" (Section 2.2.1.3.6). The descriptions and technical bases provide transparent and traceable support for the abstraction of quantity and chemistry of water contacting engineered barriers and waste forms; 
(3) Important design features, such as waste package design and material selection, backfill, drip shield, ground support, thermal loading strategy, and degradation processes, are adequate to determine the initial and boundary conditions for calculations of the quantity and chemistry of water contacting engineered barriers and waste forms;

(4) Spatial and temporal abstractions appropriately address physical couplings (thermal-hydrological-mechanical-chemical). For example, Department of Energy evaluates the potential for focusing of water flow into drifts, caused by coupled thermal-hydrologic-mechanical-chemical processes;

(6) The expected ranges of environmental conditions within the waste package emplacement drifts, inside of breached waste packages, and contacting the waste forms and their evolution with time are identified. These ranges may be developed to include:

(i) the effects of the drip shield and backfill on the quantity and chemistry of water (e.g., the potential for condensate formation and dripping from the underside of the shield);

(ii) conditions that promote corrosion of engineered barriers and degradation of waste forms;

(iii) irregular wet and dry cycles;

(iv) gamma-radiolysis; and

(v) size and distribution of penetrations of engineered barriers;

(8) Adequate technical bases are provided, including activities such as independent modeling, laboratory or field data, or sensitivity studies, for inclusion of any thermal-hydrologic-mechanical-chemical couplings and features, events, and processes;

(9) Performance-affecting processes that have been observed in thermal-hydrologic tests and experiments are included into the performance assessment. For example, the U.S. Department of Energy either demonstrates that liquid water will not reflux into the underground facility or incorporates refluxing water into the performance assessment calculation, and bounds the potential adverse effects of alteration of the hydraulic pathway that result from refluxing water.

Acceptance Criterion 2: Data Are Sufficient for Model Justification.

(4) Sufficient information to formulate the conceptual approach(es) for analyzing water contact with the drip shield, engineered barriers, and waste forms is provided. 


\subsubsection{FEPs Screening Criteria}

The basis for determining whether a particular FEP should be included in or excluded from TSPA-LA derives from the requirements specified in the NRC regulations at 10 CFR Part 63 [DIRS 173273], as well as from the acceptance criterion provided in the YMRP (NRC 2003 [DIRS 163274], Sections 2.2.1.2). For a FEP to be excluded from the TSPA-LA, it must satisfy the criteria for either low probability, low consequence or exclusion by regulation, as summarized in the following three sections. FEPs that do not meet one of these three criteria are to be included.

\section{Low Probability}

The low-probability criterion is given in 10 CFR 63.114(d) [DIRS 173273]:

Consider only events that have at least one chance in 10,000 of occurring over 10,000 years.

and supported by 10 CFR 63.342 [DIRS 173273]:

The DOE's performance assessments shall not include consideration of very unlikely features, events, or processes, i.e., those that are estimated to have less than one chance in 10,000 of occurring within 10,000 years of disposal.

\section{Low Consequence}

The low consequence criterion is given in 10 CFR 63.114 (e and f) [DIRS 173273]:

(e) Provide the technical basis for either inclusion or exclusion of specific features, events, and processes in the performance assessment. Specific features, events, and processes must be evaluated in detail if the magnitude and time of the resulting radiological exposures to the reasonably maximally exposed individual, or radionuclide releases to the accessible environment, would be significantly changed by their omission.

(f) Provide the technical basis for either inclusion or exclusion of degradation, deterioration, or alteration processes of engineered barriers in the performance assessment, including those processes that would adversely affect the performance of natural barriers. Degradation, deterioration, or alteration processes of engineered barriers must be evaluated in detail if the magnitude and time of the resulting radiological exposures to the reasonably maximally exposed individual, or radionuclide releases to the accessible environment, would be significantly changed by their omission.

and supported by 10 CFR 63.342 [DIRS 173273]:

DOE's performance assessments need not evaluate the impacts resulting from any features, events, and processes or sequences of events and processes with a higher 
chance of occurrence if the results of the performance assessments would not be changed significantly.

Some FEPs have a beneficial effect on the TSPA, as opposed to an adverse effect. As identified in 10 CFR 63.102(j) [DIRS 173273], the concept of a performance assessment includes that:

The features, events, and processes considered in the performance assessment should represent a wide range of both beneficial and potentially adverse effects on performance (e.g., beneficial effects of radionuclide sorption; potentially adverse effects of fracture flow or a criticality event). Those features, events, and processes expected to materially affect compliance with [10 CFR] 63.113(b) or be potentially adverse to performance are included, while events (event classes or scenario classes) that are very unlikely (less than one chance in 10,000 over 10,000 years) can be excluded from the analysis.

The YMRP (NRC 2003 [DIRS 163274], Section 2.2.1), states that:

In many regulatory applications, a conservative approach can be used to decrease the need to collect additional information or to justify a simplified modeling approach. Conservative estimates for the dose to the reasonably maximally exposed individual may be used to demonstrate that the proposed repository meets U.S. Nuclear Regulatory Commission regulations and provides adequate protection of public health and safety. .. The total system performance assessment is a complex analysis with many parameters, and the U.S. Department of Energy may use conservative assumptions to simplify its approaches and data collection needs. However, a technical basis ... must be provided.

On the basis of these statements, those FEPs that are demonstrated to reduce the radiological exposures to the reasonably maximally exposed individual (RMEI), or radionuclide releases to the accessible environment, can be excluded on the basis of low consequence because they have no adverse effects on performance.

\section{By Regulation}

The YMRP (NRC 2003 [DIRS 163274], Section 2.2.1.2.1.3, Acceptance Criterion 2) allows for exclusion of a FEP if the process is specifically excluded by the regulations. To wit:

The U.S. Department of Energy has provided justification for those features, events, and processes that have been excluded. An acceptable justification for excluding features, events, and processes is that either the feature, event, and process is specifically excluded by regulation; probability of the feature, event, and process (generally an event) falls below the regulatory criterion; or omission of the feature, event, and process does not significantly change the magnitude and time of the resulting radiological exposures to the reasonably maximally exposed individual, or radionuclide releases to the accessible environment.

Criteria presented here are addressed in each of the screening arguments and disposition statements presented in Section 6.2 of this report. 


\subsubsection{Completion Criteria}

Completion criteria were established in the TWP (BSC 2005 [DIRS 173694], Section 3.4) for this document. This work will be determined complete when the FEPs listed in Section 1.2 of the TWP (BSC 2005 [DIRS 173694]) have been revised or addressed to the satisfaction of the report author, checkers, reviewers, and YMP management.

\subsection{CODES, STANDARDS, AND REGULATIONS}

The applicable requirements given in 10 CFR Part 63 [DIRS 173273] are discussed in Sections 4.1 and 4.2 above. There are no other applicable codes, standards, or regulations, per LP-SIII.9Q-BSC. 


\section{INTENTIONALLY LEFT BLANK}




\section{ASSUMPTIONS}

This section addresses assumptions used in the screening of EBS FEPs. One assumption is used.

Assumption 5.1: It is assumed that future variation of the geologic setting and climate will be consistent with present knowledge of natural processes. Potential naturally occurring events of the type (but perhaps not the magnitude) that could impact the geologic setting and/or climate should have occurred at least once in the past within the geologic record used as the basis for the TSPA-LA.

Basis: This assumption is justified because it is consistent with the regulation and screening criteria. At 10 CFR 63.305(c) [DIRS 173273], DOE is directed to "vary factors related to the geology, hydrology, and climate based upon cautious, but reasonable assumptions consistent with present knowledge of factors that could affect the Yucca Mountain disposal system over the next 10,000 years." See also the discussion on the regulatory concepts for "reference biosphere" and "geologic setting" provided in Section 4.2.1 of this report.

The implication of this assumption is that any discernible impacts or processes related to past events on the site setting are presumably reflected in the present knowledge of natural processes that forms the basis of the TSPA-LA. If the subject FEP phenomena are not reflected or discernible in the data used to describe past settings, then they are either of "low consequence" or of "low probability" and can be excluded from consideration.

Confirmation Status: Because it is required by regulation, no further confirmation is necessary.

Use: This assumption is used throughout this report in the discussion of FEPs. 


\section{INTENTIONALLY LEFT BLANK}




\section{SCIENTIFIC ANALYSIS DISCUSSION}

\subsection{METHODS AND APPROACH}

The identification and screening of a comprehensive list of FEPs potentially relevant to the postclosure performance of the Yucca Mountain repository is an ongoing, iterative process based on site-specific information, design, and regulations. FEP analysis uses the following definitions, as taken from the YMRP (NRC 2003 [DIRS 163274], Glossary):

Feature - $\begin{aligned} & \text { An object, structure, or condition that has a potential to affect } \\ & \text { disposal system performance }\end{aligned}$
Event $\quad-\quad \begin{aligned} & \text { A natural or human-caused phenomenon that has a potential to } \\ & \text { affect disposal system performance and that occurs during an } \\ & \text { interval that is short compared to the period of performance }\end{aligned}$
Process - $\quad \begin{aligned} & \text { A natural or human-caused phenomenon that has a potential to } \\ & \text { affect disposal system performance and that operates during all or a } \\ & \text { significant part of the period of performance. }\end{aligned}$

FEP analysis for TSPA-LA is described in The Development of the Total System Performance Assessment-License Application Features, Events, and Processes (BSC 2005 [DIRS 173800]). It is summarized in the following subsections.

\subsubsection{Identification of EBS FEPs}

The first step of FEP analysis is FEP identification and classification, which addresses Acceptance Criterion 1 of the YMRP (NRC 2003 [DIRS 163274], Section 2.2.1.2.1.3). The TSPA-LA FEP identification and classification process is described in The Development of the Total System Performance Assessment-License Application Features, Events, and Processes (BSC 2005 [DIRS 173800], Section 3). This process produced a version of the LA FEP List and Screening (DTN: MO0501SEPFEPLA.001 [DIRS 172601], file FEPS_be.mdb, table "FEPS") used as input in this EBS FEPs analysis. Deviations in two FEP titles and descriptions in DTN: MO0501SEPFEPLA.001 [DIRS 172601] are documented in Technical Management Review Board (TMRB) Decision Proposal (TMRB-2005-047) (BSC 2005 [DIRS 174965]) and Technical Management Review Board (TMRB) Decision Proposal (TMRB-2005-050) (BSC 2005 [DIRS 174990]).

\subsubsection{Screening of EBS FEPs}

The second step of FEP analysis is FEP screening, which addresses Acceptance Criterion 2 of the YMRP (NRC 2003 [DIRS 163274], Section 2.2.1.2.1.3). The TSPA-LA FEP screening process is described in The Development of the Total System Performance Assessment-License Application Features, Events, and Processes (BSC 2005 [DIRS 173800], Section 4).

For FEP screening, each FEP is screened against the specified exclusion criteria (Section 4.2.3), summarized in the three following FEP screening statements: 
1) FEPs having less than one chance in 10,000 of occurring over 10,000 years may be excluded (screened out) from the total system performance assessment on the basis of low probability (as per 10 CFR 63.114(d) [DIRS 173273]).

2) FEPs whose omission would not significantly change the magnitude and time of the resulting radiological exposures to the RMEI, or radionuclide releases to the accessible environment, may be excluded (screened out) from the total system performance assessment on the basis of low consequence (as per 10 CFR 63.114 (e and f) [DIRS 173273]).

3) FEPs that are inconsistent with the characteristics, concepts, and definitions specified in 10 CFR Part 63 [DIRS 173273] may be excluded (screened out) from the total system performance assessment by regulation.

A FEP need only satisfy one of the exclusion screening criteria to be excluded from TSPA. A FEP that does not satisfy any of the exclusion screening criteria must be included (screened in) in the TSPA-LA model.

This report documents the screening decisions for the EBS FEPs. In cases where a FEP covers multiple technical areas and is shared with other FEP reports, this report provides only a partial technical basis for the screening decision as it relates to EBS issues. Details regarding shared aspects of a FEP (i.e., relevant features, events, or processes addressed in a shared FEP report and identification of the appropriate FEP report) are provided within each FEP analysis. The full technical basis for these shared FEPs is addressed, collectively, by all of the sharing FEP analyses.

Documentation of the screening for each FEP is provided in Section 6.2. The following standardized format is used:

Section 6.2.x FEP Name (" $x$ " represents the subsection in which the FEP is discussed: 6.2.1, for example)

FEP Number: Identification number as listed in Table 1-1.

FEP Description: This field describes the nature and scope of the FEP under consideration.

Screening Decision: Identifies the screening decision as one of:

- "Included"

- "Excluded - Low Probability"

- "Excluded - Low Consequence"

- "Excluded - By Regulation" (no occurrences in this FEP report)

Screening Argument: This field is used only for excluded FEPs. It provides the technical basis for exclusion of the FEP from TSPA-LA. 
TSPA Disposition: This field is used only for included FEPs. It provides a consolidated discussion of how a FEP has been included in TSPA-LA, making reference to more detailed documentation in other supporting technical reports.

Supporting Documents: This field is only used for included FEPs. It provides the list of supporting technical reports that identify the FEP as an included FEP and contain information relevant to the implementation of the FEP within the TSPA-LA model. This list of supporting technical reports provides traceability of the FEP through the document hierarchy. For excluded FEPs, it is indicated as "Not Applicable."

\subsubsection{Indirect Inputs}

Table 6-1 below provides a listing of "indirect inputs" to this report, i.e., references used for corroborative or supporting information. 


\begin{tabular}{|c|c|c|c|}
\hline Technical Product Input Source Title & Location in Source & $\begin{array}{l}\text { Where Used in This } \\
\text { Report }\end{array}$ & Description \\
\hline \multirow{12}{*}{$\begin{array}{l}\text { 10 CFR 63. } 2005 \text { Energy: Disposal of High-Level } \\
\text { Radioactive Wastes in a Geologic Repository at Yucca } \\
\text { Mountain, Nevada. } \\
\text { [DIRS 173273] }\end{array}$} & 10 CFR 63.2, 63.114 & Table 4-2 & $\begin{array}{l}\text { General requirements pertaining to providing } \\
\text { a performance assessment }\end{array}$ \\
\hline & 10 CFR 63.114(a) & Table 4-2 & $\begin{array}{l}\text { Include data related to geology, hydrology and } \\
\text { geochemistry (including disruptive processes } \\
\text { and events) to the extent necessary }\end{array}$ \\
\hline & $\begin{array}{l}10 \text { CFR 63.114(b), } 10 \\
\text { CFR 63.304(4) }\end{array}$ & Table 4-2 & $\begin{array}{l}\text { Account for uncertainties and variabilities in } \\
\text { parameter values and provide the technical } \\
\text { basis for parameter ranges, probability } \\
\text { distributions, or bounding values }\end{array}$ \\
\hline & 10 CFR 63.114(d), 10 CFR 63.342 & Section 6.1.2; Table 4-2 & $\begin{array}{l}\text { Provide the technical basis for either inclusion } \\
\text { or exclusion of FEPs }\end{array}$ \\
\hline & 10 CFR $63.114(d, e$ and f) & Section 1; Table 4-2 & $\begin{array}{l}\text { Provide technical basis for inclusion or } \\
\text { exclusion of features, events, and processes. } \\
\text { Need not be included if results of the } \\
\text { performance assessment would not be } \\
\text { significantly changed }\end{array}$ \\
\hline & 10 CFR $63.305(\mathrm{c})$ & Section 5 & Geologic setting \\
\hline & Entire, 10CFR 63.114(d) & $\begin{array}{l}\text { Sections } 4.2,4.2 .3,4.3 \\
6.1 .2,6.2 .1\end{array}$ & Waste disposal regulation requirements \\
\hline & $\begin{array}{l}10 \text { CFR } 63.73 \text { and Subparts F and } \\
\text { G, } 10 \text { CFR } 63.44,10 \text { CFR } 63.131\end{array}$ & Sections 1.3, 6.1.6 & $\begin{array}{l}\text { Engineering and design changes are subject } \\
\text { to evaluation }\end{array}$ \\
\hline & 10 CFR 63.114(d) & Table 4-2 & $\begin{array}{l}\text { Consider only events that have at least } \\
\text { one chance in } 10,000 \text { of occurring over } \\
10,000 \text { years. }\end{array}$ \\
\hline & 10 CFR $6.114(a)$ & Table 4-2 & $\begin{array}{l}\text { Include information of the design of the } \\
\text { engineered barrier system used to define } \\
\text { parameters and conceptual models }\end{array}$ \\
\hline & 10 CFR 63.113 & Section 2 & Postclosure performance objectives \\
\hline & 10 CFR 63 Subpart G & Appendix B, Section B.2 & Quality Assurance requirements \\
\hline
\end{tabular}


Table 6-1. Indirect Inputs (Continued)

\begin{tabular}{|c|c|c|c|}
\hline Technical Product Input Source Title & Location in Source & $\begin{array}{c}\text { Where Used in This } \\
\text { Report }\end{array}$ & Description \\
\hline $\begin{array}{l}\text { Albin, A.L.; Singleton, W.L.; Moyer, T.C.; Lee, A.C.; } \\
\text { Lung, R.C.; Eatman, G.L.W.; and Barr, D.L. 1997. } \\
\text { Geology of the Main Drift - Station 28+00 to 55+00, } \\
\text { Exploratory Studies Facility, Yucca Mountain Project, } \\
\text { Yucca Mountain, Nevada. } \\
\text { [DIRS 101367] }\end{array}$ & Entire & Appendix B, Section B.1 & Example of previous use of data \\
\hline $\begin{array}{l}\text { ASM International. 1987. Corrosion. } \\
\text { [DIRS 101992] }\end{array}$ & p. 272, Figure 54 & Section 6.2 .64 & Corrosion cracks in stainless steel \\
\hline $\begin{array}{l}\text { Beason, S. 2003. Collection of Underground Site } \\
\text { Characterization Data. Scientific Notebook SN-USGS- } \\
\text { SCI-084-V1 [final submittal]. } \\
\text { [DIRS 171953] }\end{array}$ & pp. 77 to 80,81 & Appendix B, Section B.4 & Observations of excavation effects \\
\hline $\begin{array}{l}\text { Blair, S.C.; Kelly, J.M.; Pine, O.; Pletcher, R.; and } \\
\text { Berge, P.A. 1996. Effect of Radiation on the } \\
\text { Mechanical Properties of Topopah Spring Tuff. } \\
\text { [DIRS 129637] }\end{array}$ & Tables 3 and 5 & Section 6.2 .82 & $\begin{array}{l}\text { Large doses of gamma radiation have little } \\
\text { effect on Topapah Springs tuff }\end{array}$ \\
\hline $\begin{array}{l}\text { BSC (Bechtel SAIC Company) 2001. Plugging of } \\
\text { Stress Corrosion Cracks by Precipitates. } \\
\text { [DIRS 156807] }\end{array}$ & Section 6.3 & Section 6.2 .64 & Plugging of SCC due to calcite \\
\hline $\begin{array}{l}\text { BSC 2001. Waste Package Barrier Stresses Due to } \\
\text { Thermal Expansion. } \\
\text { [DIRS 154004] }\end{array}$ & Entire & Section 6.2 .69 & Thermal stresses in waste packages \\
\hline \multirow{2}{*}{$\begin{array}{l}\text { BSC 2001. Waste Package Outer Barrier Stress Due } \\
\text { to Thermal Expansion with Various Barrier Gap Sizes. } \\
\text { [DIRS 152655] }\end{array}$} & Sections $3.1,5.1,5.3$ & Section 6.2 .69 & Thermal stresses in waste packages \\
\hline & Section 1 & Section 6.2 .29 & Larger radial thermal stress in waste package \\
\hline \multirow{5}{*}{$\begin{array}{l}\text { BSC 2004. Abstraction of Drift Seepage. } \\
\text { [DIRS 169131] }\end{array}$} & Sections 6.4.3.2, 6.6.5.1, 6.6.5.2 & Section 6.2 .33 & Flow from episodic infiltration \\
\hline & $\begin{array}{l}\text { Sections 6.3.2, 6.5.2.1, 6.7.1.1, } \\
6.7 .1 .2\end{array}$ & Section 6.2 .41 & $\begin{array}{l}\text { Discussion of condensation reflux and } \\
\text { impact on thermal seepage. Abstraction of } \\
\text { seepage quantity }\end{array}$ \\
\hline & $\begin{array}{l}\text { Sections 6.4.2.4.2, 6.5.1.5, 6.5.3, } \\
6.7 .1 .2\end{array}$ & Section 6.2.11 & Impact of drift collapse on seepage \\
\hline & Sections 6.4.3.1, 6.6.5.1 & Section 6.2 .86 & Flow in unsaturated zone \\
\hline & Section 6.8 & Section 6.2 .71 & Use of report in TSPA \\
\hline \multirow{2}{*}{$\begin{array}{l}\text { BSC 2004. Aqueous Corrosion Rates for Waste } \\
\text { Package Materials. } \\
\text { [DIRS 169982] }\end{array}$} & Section III-3.8 & Section 6.2 .23 & Qualification of corrosion data \\
\hline & Table 4-3 & Section 6.2 .23 & Corrosion rates for stainless steel \\
\hline
\end{tabular}


Table 6-1. Indirect Inputs (Continued)

\begin{tabular}{|c|c|c|c|}
\hline Technical Product Input Source Title & Location in Source & $\begin{array}{l}\text { Where Used in This } \\
\text { Report }\end{array}$ & Description \\
\hline $\begin{array}{l}\text { BSC 2004. Characterize Framework for Seismicity and } \\
\text { Structural Deformation at Yucca Mountain, Nevada. } \\
\text { [DIRS 168030] }\end{array}$ & Table 6 & Section 6.2 .7 & Cumulative fault displacement rate \\
\hline \multirow{3}{*}{$\begin{array}{l}\text { BSC 2004. Clad Degradation - FEPs Screening } \\
\text { arguments. } \\
\text { [DIRS 170019] }\end{array}$} & Sections $6,6.2 .4,6.2 .18,6.2 .20$ & $\begin{array}{l}\text { Table 1-1; Sections } \\
6.2 .28,6.2 .60 \text {, and } 6.2 .65\end{array}$ & Clad degradation FEPS \\
\hline & Entire & Section 6.1.5; Table 6-2 & Clad degradation FEPs \\
\hline & Entire & Section 1 & $\begin{array}{l}\text { General reference to FEPS dealing with } \\
\text { cladding }\end{array}$ \\
\hline \multirow[t]{6}{*}{$\begin{array}{l}\text { BSC 2004. Drift Degradation Analysis. } \\
\text { [DIRS 166107] }\end{array}$} & Sections $6.3,6.3 .1 .6 .4,6.4$ & Section 6.2 .11 & $\begin{array}{l}\text { Potential for drift collapse and } \\
\text { its consequences }\end{array}$ \\
\hline & Sections 6, 6.4.2.1 & Section 6.2 .20 & Degradation of the ground control system \\
\hline & Sections $6.3,6.3 .1 .1$ & Appendix C, Section C.2.1 | & Impact of rockfall on drip shield \\
\hline & Section 6.4.1.1 & Appendix C, Section C.1 & $\begin{array}{l}\text { Characterization of lithophysal and } \\
\text { nonlithophysal units }\end{array}$ \\
\hline & Entire & Appendix B, Section B.1 & Reference to author of document \\
\hline & Section 6 & Section 6.2 .19 & $\begin{array}{l}\text { Rock reinforcement materials will degrade } \\
\text { and fail }\end{array}$ \\
\hline $\begin{array}{l}\text { BSC 2004. Drift-Scale Radionuclide Transport. } \\
\text { [DIRS 170040] }\end{array}$ & Sections 6.3.1, 6.3.3.3; Figure 6-2d & Section 6.2 .88 & $\begin{array}{l}\text { Direction of water flow beneath } \\
\text { emplacement tunnels }\end{array}$ \\
\hline $\begin{array}{l}\text { BSC 2004. Evaluation of Emplacement Drift Stability } \\
\text { for KTI Resolutions. } \\
\text { [DIRS 168889] }\end{array}$ & Entire & Section 6.2 .27 & Loads due to thermal expansion \\
\hline $\begin{array}{l}\text { BSC 2004. Evaluation of Potential Impacts of Microbial } \\
\text { Activities on Drift Chemistry. } \\
\text { [DIRS 169991] }\end{array}$ & Sections $6.4,7.1$ & Section 6.2 .70 & $\begin{array}{l}\text { Potential impacts of microbial activity on } \\
\text { drift chemistry }\end{array}$ \\
\hline $\begin{array}{l}\text { BSC 2004. General Corrosion and Localized Corrosion } \\
\text { of Waste Package Outer Barrier. } \\
\text { [DIRS 169984] }\end{array}$ & Entire & Section 6.2 .80 & Description of corrosion model \\
\hline \multirow{3}{*}{$\begin{array}{l}\text { BSC 2004. In-Drift Natural Convection and } \\
\text { Condensation. } \\
\text { [DIRS 164327] }\end{array}$} & Sections $6.2 .5,6.3 .3$ & Section 6.2 .25 & Fluid dynamics model of natural convection \\
\hline & $\begin{array}{l}\text { Sections 4.1.2, 6.1.5.1, 6.3.3.1, } \\
\text { 6.3.5.1.2, 6.4.1.1, 8.3.2; } \\
\text { Table 4.1.3-7 }\end{array}$ & $\begin{array}{l}\text { Sections } 6.2 .66,6.2 .67 \\
6.2 .72\end{array}$ & $\begin{array}{l}\text { Heat generation in waste package as a } \\
\text { function of time }\end{array}$ \\
\hline & $\begin{array}{l}\text { Sections } 6.3,6.3 .3,6.3 .5 .1,8.3 \\
\text { 8.3.1, 8.3.1.2 }\end{array}$ & Section 6.2 .35 & In-drift condensation \\
\hline
\end{tabular}


Table 6-1. Indirect Inputs (Continued)

\begin{tabular}{|c|c|c|c|}
\hline Technical Product Input Source Title & Location in Source & $\begin{array}{c}\text { Where Used in This } \\
\text { Report }\end{array}$ & Description \\
\hline \multirow{4}{*}{$\begin{array}{l}\text { BSC 2004. In-Drift Natural Convection and } \\
\text { Condensation. } \\
\text { [DIRS 164327] } \\
\text { (Continued) }\end{array}$} & \begin{tabular}{|l|} 
Sections $6.3,6.3 .3,6.3 .5,6.3 .5 .1 .1$ \\
8.3, 8.3.1; Figures 6.3.5-2, 6.3.7-1
\end{tabular} & Section 6.2 .36 & In-drift condensation \\
\hline & Sections 6.3.1, 6.3.1.1, 8, 8.3.1 & Section 6.2 .71 & In-drift condensation \\
\hline & Section 8.3.2 & Section 6.2 .72 & $\begin{array}{l}\text { Output from convection and } \\
\text { condensation model }\end{array}$ \\
\hline & Sections 6.1.5.1, 6.4.1.1 & Section 6.2 .66 & Heat transfer mechanism \\
\hline \multirow{4}{*}{$\begin{array}{l}\text { BSC 2004. In-Drift Precipitates/Salts Model. } \\
\text { [DIRS 169863] }\end{array}$} & Section 6.6.3.5 & Section 6.2 .70 & Composition of water contacting microbes \\
\hline & Sections 4.1.2, 6.6.2.4, 6.6.3.5 & Section 6.2 .49 & $\begin{array}{l}\text { Composition of water contacting } \\
\text { waste packages }\end{array}$ \\
\hline & Section 1 & Sections $6.2 .45,6.2 .50$ & IDPS model purpose \\
\hline & Section 6.3 & Section 6.2 .20 & Thermal effects on chemical equilibria \\
\hline \multirow{3}{*}{$\begin{array}{l}\text { BSC 2004. Post-Processing Analysis for THC } \\
\text { Seepage. } \\
\text { [DIRS 169858] }\end{array}$} & Section 6.2.3.3 & Section 6.2 .41 & Selection of possible seepage waters \\
\hline & Section 6.2.3.3 & Sections $6.2 .45,6.2 .89$ & 368 water compositions \\
\hline & Section 8 & Appendix A & $\begin{array}{l}\text { Superseding document is Post-Processing } \\
\text { Analysis for THC Seepage }\end{array}$ \\
\hline \multirow{2}{*}{$\begin{array}{l}\text { BSC 2004. Postclosure Modeling and Analyses Design } \\
\text { Parameters. } \\
\text { [DIRS 169885] }\end{array}$} & Section 6.3.7; Table 10 & Section 6.2 .35 & Drip shield fabrication \\
\hline & Table 10 & Section 6.2 .36 & Well-ventilated drip shield configuration \\
\hline \multirow{2}{*}{$\begin{array}{l}\text { BSC 2004. Stress Corrosion Cracking of the Drip } \\
\text { Shield, the Waste Package Outer Barrier, and the } \\
\text { Stainless Steel Structural Material. } \\
\text { [DIRS 172203] }\end{array}$} & Section 6.2.1 & Section 6.2.8 & Residual stress thresholds \\
\hline & Sections 1, 6.3.7, 6.5.2, B6.1 & Section 6.2 .64 & Morphology of SCCs \\
\hline $\begin{array}{l}\text { BSC 2004. Structural Stability of a Drip Shield Under } \\
\text { Quasi-Static Pressure. } \\
\text { [DIRS 170791] }\end{array}$ & Sections 5.2.2, 6 & Section 6.2 .10 & Drift collapse in the lithophysal zones \\
\hline $\begin{array}{l}\text { BSC 2004. Technical Work Plan for: Near-Field } \\
\text { Environment and Transport: Coupled Processes } \\
\text { (Mountain-Scale TH/THC/THM, Drift-Scale THC } \\
\text { Seepage, and Post-Processing Analysis for THC } \\
\text { Seepage) Report Integration. } \\
\text { [DIRS 171334] }\end{array}$ & Section 1.2.3 & Appendix A & Technical work plan \\
\hline
\end{tabular}


Table 6-1. Indirect Inputs (Continued)

\begin{tabular}{|c|c|c|c|}
\hline Technical Product Input Source Title & Location in Source & $\begin{array}{l}\text { Where Used in This } \\
\text { Report }\end{array}$ & Description \\
\hline \multirow[t]{6}{*}{$\begin{array}{l}\text { BSC 2004. Ventilation Model and Analysis Report. } \\
\text { [DIRS 169862]] }\end{array}$} & Entire & $\begin{array}{l}\text { Sections } 6.2 .3,6.2 .34 \\
6.2 .66,6.2 .72\end{array}$ & Ventilation model and efficiency \\
\hline & Section 8.1 & Section 6.2 .34 & Ventilation efficiency \\
\hline & Section 8.2 & Section 6.2 .72 & $\begin{array}{l}\text { Effect of natural and forced convection } \\
\text { during ventilation }\end{array}$ \\
\hline & Appendix XIII & Section 6.2.3 & Phase change effect on ventilation \\
\hline & Section 6.4 & Section 6.2.3 & $\begin{array}{l}\text { Ventilation efficiency is computed as a } \\
\text { percentage (greater than } 70 \% \text { ) of total decay } \\
\text { heat that is removed from the repository by } \\
\text { the vent }\end{array}$ \\
\hline & Section 6.3.5 & Section 6.2 .66 & Ventilation efficiency \\
\hline \multirow{2}{*}{$\begin{array}{l}\text { BSC 2004. Waste-Form Features, Events, and } \\
\text { Processes. } \\
\text { [DIRS 170020] }\end{array}$} & Entire & $\begin{array}{l}\text { Section 6.1.5; Tables 1-1, } \\
6-2\end{array}$ & Waste form FEPs \\
\hline & $\begin{array}{l}\text { Entire; Sections } 6.2 .5,6.2 .12 \\
6.2 .17,6.2 .20,6.2 .28,6.2 .33 \\
6.2 .35,6.2 .36,6.2 .37,6.2 .38\end{array}$ & $\begin{array}{l}\text { Sections } 1,6.14,6.2 .45 \\
6.2 .46,6.2 .65,6.2 .68 \\
6.2 .70,6.2 .77,6.2 .79 \\
6.2 .80,6.2 .81,6.2 .82 \\
\end{array}$ & Reference to waste form FEPS \\
\hline $\begin{array}{l}\text { BSC 2005. Dissolved Concentration Limits of } \\
\text { Radioactive Elements. } \\
\text { [DIRS 174566] }\end{array}$ & Sections 6.5 through 6.18 & Section 6.2 .52 & Radionuclide solubilities \\
\hline \multirow{3}{*}{$\begin{array}{l}\text { BSC 2005. Drift-Scale Coupled Process (DST and TH } \\
\text { Seepage) Models. } \\
\text { [DIRS 172232] }\end{array}$} & Section 6.2.5; Figure 6.2.5-3 & Section 6.2.11 & Effects of drift collapse on temperature \\
\hline & Section 6.2.4 & Section 6.2 .41 & $\begin{array}{l}\text { Liquid phase saturation during post boiling } \\
\text { rewetting period }\end{array}$ \\
\hline & Sections 1, 6.2.4.2.1 & Section 6.2 .3 & $\begin{array}{l}\text { Ventilation efficiency relative to } \\
\text { seepage predictions }\end{array}$ \\
\hline \multirow[t]{4}{*}{$\begin{array}{l}\text { BSC 2005. Drift-Scale THC Seepage Model. } \\
\text { [DIRS 172862] }\end{array}$} & $\begin{array}{l}\text { Sections } 4.1 .7,6.2,6.2 .2 .1,6.2 .2 .2, \\
6.4\end{array}$ & Section 6.2 .45 & Composition of seepage waters \\
\hline & $\begin{array}{l}\text { Sections 4.1.7, 6.2, 6.2.2.1, 6.4, } \\
6.5 .5 .3\end{array}$ & Section 6.2 .89 & Redissolution of precipitates \\
\hline & Section 6.2.2.1 & Section 6.2 .41 & $\begin{array}{l}\text { Chemistry of condensate waters } \\
\text { above repository }\end{array}$ \\
\hline & Section 8.2 & Section 6.2.3, 6.2.45 & $\begin{array}{l}\text { Thermal load, thermal decay and } \\
\text { ventilation efficiency relative to predicting } \\
\text { near-field chemistry }\end{array}$ \\
\hline
\end{tabular}


Table 6-1. Indirect Inputs (Continued)

\begin{tabular}{|c|c|c|c|}
\hline Technical Product Input Source Title & Location in Source & $\begin{array}{c}\text { Where Used in This } \\
\text { Report }\end{array}$ & Description \\
\hline \multirow{2}{*}{$\begin{array}{l}\text { BSC 2005. Drift-Scale THC Seepage Model. } \\
\text { [DIRS 172862] } \\
\text { (Continued) }\end{array}$} & Section 6.5.5 & Section 6.2 .70 & In-drift temperature input \\
\hline & Sections $6.2,6.4$ & Section 6.2 .39 & $\begin{array}{l}\text { Seepage compositions abstracted from } \\
\text { time-dependent seepage water compositions } \\
\text { and gas-phase compositions in the host rock } \\
\text { adjacent to the drift wall }\end{array}$ \\
\hline \multirow{4}{*}{$\begin{array}{l}\text { BSC 2005. Drip Shield Structural Response to Rock } \\
\text { Fall Supplemental Calculation. } \\
\text { [DIRS 174052] }\end{array}$} & Section 7 & Appendix C, Section C.2.2 & $\begin{array}{l}\text { Analogue to the residual stress states and } \\
\text { profiles from the stress calculations }\end{array}$ \\
\hline & Sections 6.3, 6.5; Figure 6-3 & $\begin{array}{l}\text { Section 6.2.64; } \\
\text { Appendix C, Figure C-1 }\end{array}$ & Calculation approach \\
\hline & Section 3.2.2 & Appendix C, Table C-1 & Size of block evaluated \\
\hline & Figures $7-21$ to $7-25$ & Appendix C, Section C.2.2 & $\begin{array}{l}\text { Computational results for the corner-on } \\
\text { impacts }\end{array}$ \\
\hline \multirow[t]{12}{*}{$\begin{array}{l}\text { BSC 2005. EBS Radionuclide Transport Abstraction. } \\
\text { [DIRS 173433] }\end{array}$} & Sections $6.1,6.3 .1 .1,6.3 .2,6.5 .3$ & Section 6.2 .25 & $\begin{array}{l}\text { TSPA implementation of seepage, and how it } \\
\text { relates to the drip shield }\end{array}$ \\
\hline & Section 8.1 & Sections $6.2 .35,6.2 .36$ & $\begin{array}{l}\text { TSPA implementation of condensation in } \\
\text { the RTA }\end{array}$ \\
\hline & $\begin{array}{l}\text { Sections 6.1, 6.3, 6.3.1, 6.3.1.1, } \\
6.3 .3 .4,6.6 .5,7.3 .2,8 \text {; Figure 6.3-1 }\end{array}$ & Section 6.2 .37 & $\begin{array}{l}\text { Hydraulic properties of EBS components and } \\
\text { flow pathways }\end{array}$ \\
\hline & Sections 6.3.4, 6.5.3.3, 8.1 & Section 6.2 .38 & Flow in invert \\
\hline & $\begin{array}{l}\text { Sections 6.1, 6.3.1, 6.3.1.2, 6.3.4, } \\
\text { 6.3.4.2; Appendix B }\end{array}$ & Sections 6.2.46, 6.2.48 & Sorption of dissolved radionuclides in EBS \\
\hline & $\begin{array}{l}\text { Sections } 6.1,6.3 .1 .1,6.3 .4,6.3 .4 .1 \\
\text { Figure 6.3-1 }\end{array}$ & ; Section 6.2 .51 & Diffusion of radionuclides in EBS \\
\hline & $\begin{array}{l}\text { Sections 6.1, 6.3.1.1, 6.3.1.2, 6.3.4; } \\
\text { Figure 6.3-1 }\end{array}$ & ; Section 6.2 .52 & Advection of colloids in EBS \\
\hline & $\begin{array}{l}\text { Sections } 4.1,6.3 .1 .1,6.3 .4 .4 \\
6.5 .1 .2,8.2 ; \text { Figure } 6.3-1\end{array}$ & Section 6.2 .58 & $\begin{array}{l}\text { Coupled effects on radionuclide transport } \\
\text { in EBS }\end{array}$ \\
\hline & Entire & Section 6.2 .71 & Inputs to thermal effects on flow in the EBS \\
\hline & Sections $1,6.3 .1 .1,6.3 .3,8.1$ & Sections 6.2.24, 6.2.43 & Flow and transport at waste package \\
\hline & Section 6.1 & Section 6.2 .87 & Time-dependent radionuclide releases \\
\hline & Section 6.3.4 & Section 6.2 .60 & $\begin{array}{l}\text { Effects of degraded package on radionuclide } \\
\text { transport in EBS }\end{array}$ \\
\hline
\end{tabular}




\begin{tabular}{|c|c|c|c|}
\hline Technical Product Input Source Title & Location in Source & $\begin{array}{l}\text { Where Used in This } \\
\text { Report }\end{array}$ & Description \\
\hline \multirow[t]{2}{*}{$\begin{array}{l}\text { BSC 2005. EBS Radionuclide Transport Abstraction. } \\
\text { [DIRS 173433] } \\
\text { (Continued) }\end{array}$} & $\begin{array}{l}\text { Sections } 6.1,6.3,6.3 .1,6.3 .1 .1, \\
\text { 6.3.1.2, 6.3.2, 6.3.2.4, 6.3.3.2, } \\
\text { 6.3.3.4, 6.3.4, 6.3.4.1, 6.3.4.4, 6.5, } \\
\text { 6.5.3.2; Tables 4-1, 6.3-1; Figure } \\
\text { 6.3-1 }\end{array}$ & $\begin{array}{l}\text { Sections } 6.2 .39,6.2 .48 \\
6.2 .51,6.2 .52,6.2 .54\end{array}$ & Water movement in EBS \\
\hline & Section 5.5 & $\begin{array}{l}\text { Sections } 6.2 .11,6.2 .52 \\
6.2 .63\end{array}$ & $\begin{array}{l}\text { Diffusive transport out of the package will not } \\
\text { occur because water vapor films are expected } \\
\text { to evaporate }\end{array}$ \\
\hline \multirow{9}{*}{$\begin{array}{l}\text { BSC 2005. Engineered Barrier System: Physical and } \\
\text { Chemical Environment. } \\
\text { [DIRS 175083] }\end{array}$} & Section 6.9 & Section 6.2 .90 & Evaporation effects on chemistry \\
\hline & Sections $1,6.6,6.9,6.13,6.13 .4$ & $\begin{array}{l}\text { Sections } 6.2 .38,6.2 .39 \\
6.2 .45,6.2 .89\end{array}$ & Flow and composition of in-drift waters \\
\hline & $\begin{array}{l}\text { Sections } 6.5,6.7,6.8,6.9 \\
6.12 .4 .1 .3 ; \text { Table } 6.5-2\end{array}$ & Section 6.2 .50 & Reaction kinetics \\
\hline & Section 6.9.4 & Section 6.2 .66 & $\begin{array}{l}\text { Water compositions resulting from } \\
\text { seepage evaporation }\end{array}$ \\
\hline & Sections 1, 6.6 & $\begin{array}{l}\text { Sections } 6.2 .38,6.2 .39 \\
6.2 .45\end{array}$ & Chemistry of water wicked into the invert \\
\hline & Sections $6.6,6.9,6.13$ & Section 6.2 .45 & In-drift water compositions \\
\hline & Sections $6.7,6.8$ & Section 6.2 .46 & Corrosion rates of EBS components \\
\hline & $\begin{array}{l}\text { Sections 6.7, 6.7.1, 6.7.1.2; } \\
\text { Figure 6.7-2 }\end{array}$ & Section 6.2 .49 & Corrosion rates of EBS components \\
\hline & Sections $6.8,6.9$ & Section 6.2 .70 & Chemical effects of rock reinforcement \\
\hline $\begin{array}{l}\text { BSC 2005. Features, Events, and Processes in SZ } \\
\text { Flow and Transport. } \\
\text { [DIRS } 174190\end{array}$ & Section 6.2 .27 & Section 6.2 .60 & Effects of flow processes on transport \\
\hline \multirow{3}{*}{$\begin{array}{l}\text { BSC 2005. Features, Events, and Processes in UZ } \\
\text { Flow and Transport. } \\
\text { [DIRS 174191] }\end{array}$} & Section 6.2 .1 & Section 6.2 .3 & Reference to FEP 1.1.02.02.0A \\
\hline & $\begin{array}{l}\text { Sections } 6.9 .3,6.9 .7,6.9 .10 \\
6.9 .11,6.9 .12,6.9 .13,6.2 .15 \\
6.2 .16,6.2 .18,6.2 .23,6.2 .35\end{array}$ & Section 6.2 .60 & $\begin{array}{l}\text { Reference to FEPs 2.2.08.03.0B, } \\
\text { 2.2.10.06.0A, 2.2.01.02.0A, 2.2.10.04.0A, } \\
\text { 2.2.10.04.0B, 2.2.10.05.0A, 2.2.07.04.0A, } \\
\text { 2.2.07.06.0B, 2.2.07.08.0A, 2.2.10.10.0A, } \\
\text { 2.207.18.0A }\end{array}$ \\
\hline & Section 6.9 .2 & $\begin{array}{l}\text { Sections 6.2.1, 6.2.18, } \\
6.2 .45\end{array}$ & Reference to FEP 2.2.01.01.0B \\
\hline
\end{tabular}


Table 6-1. Indirect Inputs (Continued)

\begin{tabular}{|c|c|c|c|}
\hline Technical Product Input Source Title & Location in Source & $\begin{array}{l}\text { Where Used in This } \\
\text { Report }\end{array}$ & Description \\
\hline \multirow{10}{*}{$\begin{array}{l}\text { BSC 2005. Features, Events, and Processes in UZ } \\
\text { Flow and Transport. } \\
\text { [DIRS 174191] } \\
\text { (Continued) }\end{array}$} & Section 6.2 .30 & Section 6.2 .57 & Reference to 2.2.08.09.0B \\
\hline & Section 6 & Section 6.1.5; Table 1-1 & UZ flow and transport FEPs \\
\hline & Section 6.9.3 & Section 6.2 .84 & Reference to FEP 2.2.01.02.0A \\
\hline & Sections 6.4.5, 6.4.6 & Section 6.2 .86 & Episodic or pulse release from repository \\
\hline & Section 6.2 .16 & Section 6.2 .87 & Long-term release of radionuclides \\
\hline & Section 6.2 .27 & Section 6.2 .89 & Corrosive fluids \\
\hline & Section 6.9 .2 & Section 6.2 .1 & $\begin{array}{l}\text { Potential for chemical changes to the host } \\
\text { rock or seepage water }\end{array}$ \\
\hline & Section 6.2 .25 & Section 6.2 .88 & The drift shadow effect \\
\hline & Section 6.7.3 & Section 6.2 .79 & $\begin{array}{l}\text { Radionuclides that would have a potential for } \\
\text { gas transport }\end{array}$ \\
\hline & Entire & Section 7.1.2; Table 6-2 & $\begin{array}{l}\text { Quantity and chemistry of water contacting } \\
\text { engineered barriers }\end{array}$ \\
\hline \multirow[t]{3}{*}{$\begin{array}{l}\text { BSC 2005. Features, Events, and Processes: } \\
\text { Disruptive Events. } \\
\text { [DIRS 173981] }\end{array}$} & $\begin{array}{l}\text { Sections } 6.2 .1 .2,6.2 .1 .3,6.2 .1 .4 \\
6.2 .1 .5,6.2 .1 .6\end{array}$ & $\begin{array}{l}\text { Sections } 6.2 .7,6.2 .8 \\
\text { 6.2.9, 6.2.10, 6.2.11; } \\
\text { Table 6-2 }\end{array}$ & Damage to EBS components \\
\hline & Entire & $\begin{array}{l}\text { Section 6.1.5; Tables 1-1, } \\
6-2\end{array}$ & Disruptive events FEPs \\
\hline & Section 6.2.2.3 & Section 6.2.6; Table 6-2 & Magma plugs and their functions \\
\hline $\begin{array}{l}\text { BSC 2005. IED Interlocking Drip Shield and } \\
\text { Emplacement Pallet [Sheet } 1 \text { of } 1] . \\
\text { [DIRS 173303] }\end{array}$ & Entire & Section 6.2 .80 & $\begin{array}{l}\text { Durability of waste package materials and } \\
\text { resistance to corrosion }\end{array}$ \\
\hline $\begin{array}{l}\text { BSC 2005. IED Waste Package Configuration [Sheet } 1 \\
\text { of 1]. } \\
\text { [DIRS 173501] }\end{array}$ & Entire & Section 6.2 .69 & Lid to outer lid gap of $\sim 30 \mathrm{~mm}$ \\
\hline \multirow[t]{3}{*}{$\begin{array}{l}\text { BSC 2005. Multiscale Thermohydrologic Model. } \\
\text { [DIRS 173944] }\end{array}$} & $\begin{array}{l}\text { Sections 1, 6.1, 6.2, 6.3.1.1, 6.3.3; } \\
\text { Tables 4.1-1, 6.3-8; Appendix XV }\end{array}$ & $\begin{array}{l}\text { Section } 6.2 .37,6.2 .38 \\
6.2 .39,6.2 .41\end{array}$ & Water flux into invert \\
\hline & $\begin{array}{l}\text { Sections } 1,4.1 .1 .3,6.2 .5,6.2 .8 .5 \\
6.3 .1 .2 ; \text { Tables } 1-1,6.3-13,6.3-14 \\
6.3-15\end{array}$ & $\begin{array}{l}\text { Sections } 6.2 .66,6.2 .67 \\
6.2 .71\end{array}$ & Selected inputs and outputs from MSTHM \\
\hline & Section 6.2 & Section 6.2.34 & Thermohydrologic modeling methodology \\
\hline
\end{tabular}


Table 6-1. Indirect Inputs (Continued)

\begin{tabular}{|c|c|c|c|}
\hline Technical Product Input Source Title & Location in Source & $\begin{array}{l}\text { Where Used in This } \\
\text { Report }\end{array}$ & Description \\
\hline $\begin{array}{l}\text { BSC 2005. Multiscale Thermohydrologic Model. } \\
\text { [DIRS 173944] }\end{array}$ & $\begin{array}{l}\text { Sections 6.3.7, 6.3.7.3; } \\
\text { Table 6.3-44 }\end{array}$ & Section 6.2 .11 & $\begin{array}{l}\text { In-drift thermal-hydrologic conditions post } \\
\text { seismic event }\end{array}$ \\
\hline \multirow[t]{6}{*}{ (Continued) } & Section 6.1.3 & Section 6.2.1 & Dryout of the repository during ventilation \\
\hline & Sections 8.1, 8.3; Table 6.5-1 & Section 6.2.3 & $\begin{array}{l}\text { Multiscale thermohydrologic model accounts } \\
\text { for ventilation }\end{array}$ \\
\hline & Section 8.3 & Section 6.2.3 & $\begin{array}{l}\text { Multiscale thermohydrologic model inputs } \\
\text { to TSPA }\end{array}$ \\
\hline & Sections $4,6.2$ & Section 6.2 .71 & Metrology and input for MSTHM \\
\hline & Section 6.3 & Section 6.2.71 & Results from MSTHM \\
\hline & Section 6.2.10, 6.2.10.3, 6.3.1 & Section 6.2 .11 & Temperature and RH sensitivity calculation \\
\hline $\begin{array}{l}\text { BSC 2005. Peak Ground Velocities for Seismic Events } \\
\text { at Yucca Mountain, Nevada. } \\
\text { [DIRS 170137] }\end{array}$ & Section 6.8; Appendix C & Section 6.2.8 & $\begin{array}{l}\text { PGV levels corresponding to annual } \\
\text { exceedance frequencies }\end{array}$ \\
\hline $\begin{array}{l}\text { BSC 2005. Q-List. } \\
\text { [DIRS 174269] }\end{array}$ & $\begin{array}{l}\text { Appendix A, Table A-1, } \\
\text { "Engineered Barrier System" and } \\
\text { "Subsurface Facility, Emplacement } \\
\text { Drift" subsystems }\end{array}$ & $\begin{array}{l}\text { Sections 2, 6.1.5; } \\
\text { Figure 6-1 }\end{array}$ & List of items and barriers \\
\hline $\begin{array}{l}\text { BSC 2005. Safety Classification of SSCs and Barriers. } \\
\text { [DIRS 174836] }\end{array}$ & Table A-1 & Section 6.1.5 & Definition of the EBS \\
\hline \multirow{9}{*}{$\begin{array}{l}\text { BSC 2005. Screening of Features, Events, and } \\
\text { Processes in Drip Shield and Waste Package } \\
\text { Degradation. } \\
\text { [DIRS 174995] }\end{array}$} & Sections $6.2 .6,6.2 .2$ & Section 6.2 .61 & $\begin{array}{l}\text { Localized and general corrosion of the waste } \\
\text { package }\end{array}$ \\
\hline & Section 6.2.9 & Section 6.2 .26 & $\begin{array}{l}\text { Hydride cracking (reference to FEP discussion } \\
\text { only) }\end{array}$ \\
\hline & Section 6.2.4 & Section 6.2 .60 & Stress corrosion of metals \\
\hline & Section 6.2 .18 & Section 6.2 .61 & $\begin{array}{l}\text { Localized corrosion due to deliquescence } \\
\text { (shared FEP) }\end{array}$ \\
\hline & Sections $6.2 .8,6.2 .9$ & Section 6.2 .82 & Repository radiation fluxes \\
\hline & Section 6.2 .21 & Section 6.2 .27 & $\begin{array}{l}\text { Mechanical effects at EBS } \\
\text { component interfaces }\end{array}$ \\
\hline & Section 6.2.22 & Section 6.2 .28 & Rockfall \\
\hline & Entire & $\begin{array}{l}\text { Section } 6.1 .5 \text {, Tables } 1-1 \\
6-2\end{array}$ & Drip shield and waste package degradation \\
\hline & Sections 6.2.10, 6.2.11 & Section 6.2 .65 & $\begin{array}{l}\text { Microbially induced corrosion of the } \\
\text { waste package and drip shield }\end{array}$ \\
\hline
\end{tabular}


Table 6-1. Indirect Inputs (Continued)

\begin{tabular}{|c|c|c|c|}
\hline Technical Product Input Source Title & Location in Source & $\begin{array}{l}\text { Where Used in This } \\
\text { Report }\end{array}$ & Description \\
\hline \multirow{3}{*}{$\begin{array}{l}\text { BSC 2005. Screening of Features, Events, and } \\
\text { Processes in Drip Shield and Waste Package } \\
\text { Degradation. } \\
\text { [DIRS 174995] } \\
\text { (Continued) }\end{array}$} & Entire & Section 1 & $\begin{array}{l}\text { FEPs specific to the waste package and } \\
\text { drip shield are also addressed in separate } \\
\text { FEP reports }\end{array}$ \\
\hline & Section 6.2 .29 & Section 6.2 .69 & $\begin{array}{l}\text { Thermal expansion/stress of in-drift EBS } \\
\text { components (shared FEP) }\end{array}$ \\
\hline & Section 6.2.3 & Section 6.2.62 & General corrosion of the drip shield \\
\hline \multirow{6}{*}{$\begin{array}{l}\text { BSC 2005. Seismic Consequence Abstraction. } \\
\text { [DIRS 173247] }\end{array}$} & Sections 6.3.3, 6.3.6, 6.5.5 & Section 6.2 .27 & Response of drip shield to seismic event \\
\hline & $\begin{array}{l}\text { Sections } 6.7,6.7 .2 .1,6.7 .2 .2,6.7 .5 \\
\text { 6.9, 6.9.2 (Operations } 3 \text { through } \\
\text { 11), 6.10; Table 6.9-1 }\end{array}$ & Section 6.2.7 & $\begin{array}{l}\text { Potential for fault displacements, damage } \\
\text { abstraction for sheared waste package }\end{array}$ \\
\hline & Sections $6.8,6.8 .1,6.8 .2$ & Section 6.2 .11 & $\begin{array}{l}\text { Potential in-drift environment change after a } \\
\text { seismic event }\end{array}$ \\
\hline & Section 6.9.2 & Section 6.2 .11 & Methodology for post-seismic event \\
\hline & Sections 6.5.2, 6.5.4.1 & Section 6.2.8 & Response of invert to seismic ground motion \\
\hline & $\begin{array}{l}\text { Sections } 6.3,6.3 .2,6.3 .3,6.5 .1 .1 \\
\text { 6.5.1.6.5.2, 6.5.3, 6.5.6.2, 6.6.1.2, } \\
\text { 6.7.1, 6.9.2; Table 6.9-1 }\end{array}$ & Section 6.2.8 & Seismic damage to EBS components \\
\hline $\begin{array}{l}\text { BSC 2005. Subsurface Facility Description Document. } \\
\text { [DIRS 174514] }\end{array}$ & Section 4.1.1.3 & Section 6.2 .66 & Preclosure ventilation design period \\
\hline $\begin{array}{l}\text { BSC 2005. Technical Management Review Board } \\
\text { (TMRB) Decision Proposal. TMRB-2005-047. } \\
\text { [DIRS 174965] }\end{array}$ & Entire & $\begin{array}{l}\text { Sections 1.2, 4.1.1, 6.1.1, } \\
6.1 .5,7.1 .1 ; \text { Tables 1-1, } \\
6-2\end{array}$ & $\begin{array}{l}\text { Reference to TMRB-047 description, Dust } \\
\text { Deliquescence for waste package. }\end{array}$ \\
\hline $\begin{array}{l}\text { BSC 2005. Technical Management Review Board } \\
\text { (TMRB) Decision Proposal. TMRB-2005-050. } \\
\text { [DIRS 174990] }\end{array}$ & Entire & $\begin{array}{l}\text { Sections 1.2, 4.1.1, 6.1.1, } \\
6.1 .5,7.1 .1 ; \text { Tables 1-1, } \\
6-2\end{array}$ & $\begin{array}{l}\text { Reference to TMRB-047 description, Dust } \\
\text { Deliquescence for drip shield. }\end{array}$ \\
\hline \multirow{4}{*}{$\begin{array}{l}\text { BSC 2005. Technical Work Plan for: Revision to EBS } \\
\text { FEPS Document. } \\
\text { [DIRS 173694] }\end{array}$} & $\begin{array}{l}\text { Entire; Sections 2.2.1.2.1.3, } \\
\text { 2.2.1.3.3.3 }\end{array}$ & Sections $1.1,2$ & Guidance for this report \\
\hline & Sections 2.2.1.2.1.3, 2.2.1.3.3.3, 3 & $\begin{array}{l}\text { Sections 4, 4.2, 4.2.2.1, } \\
\text { 4.2.2.2 }\end{array}$ & Criteria relevant to the FEP screening process \\
\hline & Section 3.2 & Sections $4.2 .1,4.2 .2$ & $\begin{array}{l}\text { Regulatory criteria that are relevant to } \\
\text { developing and screening FEPs }\end{array}$ \\
\hline & Sections 1.2, 3.4 & Section 4.2.4 & Completion criteria \\
\hline
\end{tabular}


Table 6-1. Indirect Inputs (Continued)

\begin{tabular}{|c|c|c|c|}
\hline Technical Product Input Source Title & Location in Source & $\begin{array}{c}\text { Where Used in This } \\
\text { Report }\end{array}$ & Description \\
\hline \multirow{6}{*}{$\begin{array}{l}\text { BSC 2005. The Development of the Total System } \\
\text { Performance Assessment-License Application } \\
\text { Features, Events, and Processes. } \\
\text { [DIRS 173800] }\end{array}$} & Sections $2.4,3,4$ & Section 1.2 & Development of TSPA-LA FEPs \\
\hline & Entire & Section 6.1 & FEP analysis for TSPA-LA \\
\hline & Section 3 & Section 6.1.1 & $\begin{array}{l}\text { TSPA-LA FEP identification and } \\
\text { classification process }\end{array}$ \\
\hline & Section 4 & Section 6.1.2 & TSPA-LA FEP screening process \\
\hline & Section 6 & Section 6.1.6 & FEP database description \\
\hline & Section 2 & Section 7.1.1 & Acceptance Criterion 1 \\
\hline \multirow{2}{*}{$\begin{array}{l}\text { BSC 2005. Waste Form and In-Drift Colloids- } \\
\text { Associated Radionuclide Concentrations: Abstraction } \\
\text { and Summary. } \\
\text { [DIRS 174290] }\end{array}$} & Entire & Section 6.2 .58 & $\begin{array}{l}\text { Formation, stability, and concentration } \\
\text { of colloids }\end{array}$ \\
\hline & Entire & Section 6.2 .54 & Types of colloids transported in EBS \\
\hline $\begin{array}{l}\text { Christensen, H. and Sunder, S. 2000. "Current State of } \\
\text { Knowledge of Water Radiolysis Effects on Spent } \\
\text { Nuclear Fuel Corrosion." } \\
\text { [DIRS 162387] }\end{array}$ & Entire & Appendix A & Qualification of data \\
\hline $\begin{array}{l}\text { CRWMS M\&O 2000. Initial Cladding Condition. } \\
\text { [DIRS 151659] }\end{array}$ & Section 6.3 & Sections 6.2.78, 6.2.79 & $\begin{array}{l}\text { Most of the fission gas that is produced is held } \\
\text { in the fuel matrix and is not available to } \\
\text { pressurize the cladding }\end{array}$ \\
\hline $\begin{array}{l}\text { Dean, J.A. 1992. Lange's Handbook of Chemistry. } \\
\text { [DIRS 100722] }\end{array}$ & Table 5.22 & Section 6.2 .80 & Lower explosion limit of hydrogen \\
\hline $\begin{array}{l}\text { DOE (U.S. Department of Energy) 2002. Final } \\
\text { Environmental Impact Statement for a Geologic } \\
\text { Repository for the Disposal of Spent Nuclear Fuel and } \\
\text { High-Level Radioactive Waste at Yucca Mountain, Nye } \\
\text { County, Nevada. } \\
\text { [DIRS 155970] }\end{array}$ & Section I.7 & Sections $6.2 .78,6.2 .79$ & $\begin{array}{l}\text { Radionuclide transport into the } \\
\text { aqueous phase }\end{array}$ \\
\hline \multirow{2}{*}{$\begin{array}{l}\text { DOE (U.S. Department of Energy) 2004. Quality } \\
\text { Assurance Requirements and Description. } \\
\text { [DIRS 171539] }\end{array}$} & Entire & Section 2; Appendix A & QARD \\
\hline & Supplement III & Appendix B & QARD \\
\hline $\begin{array}{l}\text { DOE (U.S. Department of Energy) 1998. Update to } \\
\text { Assessment of Direct Disposal in Unsaturated Tuff of } \\
\text { Spent Nuclear Fuel and High-Level Waste Owned by } \\
\text { U.S. Department of Energy. } \\
\text { [DIRS 122980] }\end{array}$ & Section ES 3.4 & Section 6.2 .68 & Heat of oxidizing reactions, quantity of waste \\
\hline
\end{tabular}


Table 6-1. Indirect Inputs (Continued)

\begin{tabular}{|c|c|c|c|}
\hline Technical Product Input Source Title & Location in Source & $\begin{array}{c}\text { Where Used in This } \\
\text { Report }\end{array}$ & Description \\
\hline $\begin{array}{l}\text { Eatman, G.L.W.; Singleton, W.L.; Moyer, T.C.; Barr, } \\
\text { D.L.; Albin, A.L.; Lung, R.C.; and Beason, S.C. } 1997 . \\
\text { Geology of the South Ramp - Station } 55+00 \text { to } 78+77, \\
\text { Exploratory Studies Facility, Yucca Mountain Project, } \\
\text { Yucca Mountain, Nevada. } \\
\text { [DIRS 157677] }\end{array}$ & Entire & Appendix B, Section B.2 & Prior uses of data \\
\hline $\begin{array}{l}\text { Etherington, H., ed. 1958. Nuclear Engineering } \\
\text { Handbook. } \\
\text { [DIRS 164789] }\end{array}$ & pp. 10 to 107 & Section 6.2 .82 & Nuclear engineering handbook \\
\hline $\begin{array}{l}\text { Fix, D.V.; Estill, J.C.; Wong, L.L.; and Rebak, R.B. } \\
\text { 2004. "Susceptibility of Welded and Non-Welded } \\
\text { Titanium Alloys to Environmentally Assisted Cracking } \\
\text { in Simulated Concentrated Ground Waters.". } \\
\text { [DIRS 169321] }\end{array}$ & $\begin{array}{l}\text { Sections "Results and Discussion" } \\
\text { and "Experimental" }\end{array}$ & $\begin{array}{l}\text { Sections } 6.2 .64 \\
\text { Appendix C, Section C.2.1 }\end{array}$ & $\begin{array}{l}\text { Displacement-controlled stresses are } \\
\text { expected to relax over time }\end{array}$ \\
\hline $\begin{array}{l}\text { Forester, R.M.; Bradbury, J.P.; Carter, C.; Elvidge- } \\
\text { Tuma, A.B.; Hemphill, M.L.; Lundstrom, S.C.; Mahan, } \\
\text { S.A.; Marshall, B.D.; Neymark, L.A.; Paces, J.B.; } \\
\text { Sharpe, S.E.; Whelan, J.F.; and Wigand, P.E. } 1999 . \\
\text { The Climatic and Hydrologic History of Southern } \\
\text { Nevada During the Late Quaternary. } \\
\text { [DIRS 109425] }\end{array}$ & Entire; p. 57 & Sections 6.2.30, 6.2.31 & Historical water table \\
\hline $\begin{array}{l}\text { Gdowski, G.E. and Bullen, D.B. 1988. Oxidation and } \\
\text { Corrosion. Volume } 2 \text { of Survey Of Degradation Modes } \\
\text { of Candidate Materials for High-Level Radioactive- } \\
\text { Waste Disposal Containers. } \\
\text { [DIRS 100860] }\end{array}$ & Figure 19 & Section 6.2 .23 & Stainless steel degradation rate \\
\hline $\begin{array}{l}\text { Glass, R.S.; Overturf, G.E.; Van Konynenburg, R.A.; } \\
\text { and McCright, R.D. 1986. "Gamma Radiation Effects } \\
\text { on Corrosion-I. Electrochemical Mechanisms for the } \\
\text { Aqueous Corrosion Processes of Austenitic Stainless } \\
\text { Steels Relevant to Nuclear Waste Disposal in Tuff." } \\
\text { [DIRS 105021] }\end{array}$ & Entire & Appendix A, & Qualification of use of information \\
\hline $\begin{array}{l}\text { Gordon, G. 2005. "Relevant Titanium Alloy Low } \\
\text { Temperature Creep Properties." } \\
\text { [DIRS 173726] }\end{array}$ & Entire & Section 6.2 .64 & $\begin{array}{l}\text { Titanium is susceptible to creep at } \\
\text { lower temperatures }\end{array}$ \\
\hline
\end{tabular}


Table 6-1. Indirect Inputs (Continued)

\begin{tabular}{|c|c|c|c|}
\hline Technical Product Input Source Title & Location in Source & $\begin{array}{c}\text { Where Used in This } \\
\text { Report }\end{array}$ & Description \\
\hline $\begin{array}{l}\text { Green, R.T.; Evans, D.D.; and Filippone, W.L. } 1987 . \\
\text { "Effect of Electric Fields on Vapor Transport Near a } \\
\text { High-Level Waste Canister." } \\
\text { [DIRS 170174] }\end{array}$ & Entire & Section 6.2 .60 & Generation of electric fields around HLWS \\
\hline $\begin{array}{l}\text { Keenan, J.H.; Keyes, F.G.; Hill, P.G.; and Moore, J.G. } \\
\text { 1969. Steam Tables, Thermodynamic Properties of } \\
\text { Water Including Vapor, Liquid, and Solid Phases } \\
\text { (English Units). } \\
\text { [DIRS 134666] }\end{array}$ & Entire & Section 6.2 .74 & Phase transition from water to vapor \\
\hline $\begin{array}{l}\text { Larrabee, C.P. 1953. "Corrosion Resistance of High- } \\
\text { Strength Low-Alloy Steels as Influenced by } \\
\text { Composition and Environment." } \\
\text { [DIRS 159337] }\end{array}$ & pp. 259 to 271 & Section 6.2 .23 & Stainless steel degradation rate \\
\hline $\begin{array}{l}\text { LB0408CMATUZFT.004. Leaching of Altered } \\
\text { Cementitious Materials - EQ3/6 Simulations for } \\
\text { Cementitious Material Transport. } \\
\text { [DIRS 171706] }\end{array}$ & $\begin{array}{l}\text { File LB0408CMATFT.004.doc; } \\
\text { Table: "Estimated Depth of Rock } \\
\text { Voids Filled with Calcite Due to the } \\
\text { Leaching of Portlandite from } \\
\text { Shotcrete in a Main Access Drift } \\
\text { Turnout Intersection" }\end{array}$ & Section 6.2 .18 & Calcite precipitation beneath turnouts \\
\hline $\begin{array}{l}\text { Lee, S. and Staehle, R.W. 1994. Report to TRW on } \\
\text { Contract No. DX 1456KP2L, Adsorption Studies of } \\
\text { Water on Gold, Copper, Nickel and Iron Using the } \\
\text { Quartz-Crystal Microbalance Technique. } \\
\text { [DIRS 154380] }\end{array}$ & p. 73 & Section 6.2 .52 & Adsorption studies of water \\
\hline $\begin{array}{l}\text { Lide, D.R., ed. 1991. CRC Handbook of Chemistry and } \\
\text { Physics. } \\
\text { [DIRS 131202] }\end{array}$ & p. $14-10$ & Appendix A & $\mathrm{pH}$ of rainwater \\
\hline $\begin{array}{l}\text { LL040310323122.044. Input and Output Files of the } \\
\text { MSTHM Micro-Abstractions for the Collapsed-Drift } \\
\text { Cases for the TSPA-LA Low-Probability Seismic } \\
\text { Scenario. } \\
\text { [DIRS 168769] }\end{array}$ & All ".dat" files & Section 6.2 .11 & Changes to temperature and relative humidity \\
\hline $\begin{array}{l}\text { Manaktala, H.K. 1993. Characteristics of Spent } \\
\text { Nuclear Fuel and Cladding Relevant to High-Level } \\
\text { Waste Source Term. } \\
\text { [DIRS 101719] }\end{array}$ & Section 3.3.6 & Sections 6.2.78, 6.2.79 & Fission gas inventory \\
\hline
\end{tabular}


Table 6-1. Indirect Inputs (Continued)

\begin{tabular}{|c|c|c|c|}
\hline Technical Product Input Source Title & Location in Source & $\begin{array}{c}\text { Where Used in This } \\
\text { Report }\end{array}$ & Description \\
\hline $\begin{array}{l}\text { Manteufel, R.D.; Ahola, M.P.; Turner, D.R.; and } \\
\text { Chowdhury, A.H. 1993. A Literature Review of Coupled } \\
\text { Thermal-Hydrologic-Mechanical-Chemical Processes } \\
\text { Pertinent to the Proposed High-Level Nuclear Waste } \\
\text { Repository at Yucca Mountain. } \\
\text { [DIRS 100776] }\end{array}$ & Entire & Section 6.2 .60 & One-way coupled processes \\
\hline $\begin{array}{l}\text { McGraw, M.A. 1996. The Effect of Colloid Size, Colloid } \\
\text { Hydrophobicity, and Volumetric Water Content on the } \\
\text { Transport of Colloids Through Porous Media. } \\
\text { [DIRS 108218] }\end{array}$ & Entire & Section 6.2 .57 & Effects of saturation on colloid transport \\
\hline \multirow{3}{*}{$\begin{array}{l}\text { NRC (U.S. Nuclear Regulatory Commission) } 2003 . \\
\text { Yucca Mountain Review Plan, Final Report. } \\
\text { [DIRS 163274] }\end{array}$} & Entire & $\begin{array}{l}\text { Sections 1, 6.1, 6.1.1, } \\
6.1 .2\end{array}$ & Reference only \\
\hline & Entire & Section 4.2.3 & Screening material \\
\hline & Glossary & Section 6.1 & Definitions \\
\hline $\begin{array}{l}\text { Perry, R.H.; Green, D.W.; and Maloney, J.O., eds. } \\
\text { 1984. Perry's Chemical Engineers' Handbook. } \\
\text { [DIRS 125806] }\end{array}$ & Section 3 & Appendix A & Soret effect \\
\hline $\begin{array}{l}\text { Piron, J.P. and Pelletier, M. 2001. "State of the Art on } \\
\text { the Helium Issues." } \\
\text { [DIRS 165318] }\end{array}$ & Section 5.3 & Section 6.2 .75 & $\begin{array}{l}\text { Pressurization of the fuel rods from alpha } \\
\text { decay helium production }\end{array}$ \\
\hline $\begin{array}{l}\text { Plinski, M.J. 2001. Waste Package Operations } \\
\text { Fabrication Process Report. } \\
\text { [DIRS 156800] }\end{array}$ & Section 8.1.8 & Section 6.2 .69 & Waste package fabrication criteria \\
\hline $\begin{array}{l}\text { Pulvirenti, A.L.; Needham, K.M.; Adel-Hadadi, M.A.; } \\
\text { Marks, C.R.; Gorman, J.A.; and Barkatt, A. } 2002 . \\
\text { "Effects of Lead, Mercury, and Reduced Sulfur Species } \\
\text { on the Corrosion of Alloy } 22 \text { in Concentrated } \\
\text { Groundwaters as a Function of pH and Temperature." } \\
\text { [DIRS 165537] }\end{array}$ & Entire & Section 6.2 .49 & Shifts in acid-base conditions \\
\hline $\begin{array}{l}\text { Rousseau, J.P.; Kwicklis, E.M.; and Gillies, D.C., eds. } \\
\text { 1999. Hydrogeology of the Unsaturated Zone, North } \\
\text { Ramp Area of the Exploratory Studies Facility, Yucca } \\
\text { Mountain, Nevada. } \\
\text { [DIRS 102097] }\end{array}$ & pp. 55,56 & Sections $6.2 .74,6.2 .78$ & Relative permeability of the repository \\
\hline
\end{tabular}


Table 6-1. Indirect Inputs (Continued)

\begin{tabular}{|l|l|l|l|}
\hline \multicolumn{1}{|c|}{ Technical Product Input Source Title } & \multicolumn{1}{c|}{ Location in Source } & \multicolumn{1}{c|}{$\begin{array}{c}\text { Where Used in This } \\
\text { Report }\end{array}$} & Description \\
\hline $\begin{array}{l}\text { Southwell, C.R.; Bultman, J.D.; and Alexander, A.L. } \\
\text { 1976. "Corrosion of Metals in Tropical Environments - } \\
\text { Final Report of 16-Year Exposures." } \\
\text { [DIRS 100927] }\end{array}$ & Table 4 & Section 6.2.23 & Stainless steel degradation rate \\
\hline $\begin{array}{l}\text { Vidal, O. and Murphy, W.M. 1999. "Calculation of the } \\
\text { Effect of Gaseous Thermodiffusion and } \\
\text { Thermogravitation Processes on the Relative Humidity } \\
\text { Surrounding a High Level Nuclear Waste Canister." } \\
\text { [DIRS 171801] }\end{array}$ & Entire & Section 6.2.60 & $\begin{array}{l}\text { Temperature gradients during the } \\
\text { heating pulse }\end{array}$ \\
\hline
\end{tabular}




\subsubsection{Assumptions and Simplifications}

For included FEPs, the TSPA dispositions may include statements regarding assumptions made to implement the FEP within the TSPA-LA model. Such statements are descriptive of the manner in which a FEP has been included and are not used as the basis of the screening decision to include the FEP with the TSPA-LA model.

Because the individual FEPs are specific in nature, any discussion of applicable mathematical formulations, equations, algorithms, numerical methods, or idealizations or simplifications is provided within the individual FEP discussions in Section 6.2, as appropriate.

\subsubsection{Definition of the EBS}

The components identified as Important to Waste Isolation (ITWI) that make up the EBS are presented in Safety Classification of SSCs and Barriers (BSC 2005 [DIRS 174836], Table A-1, "Engineered Barrier System" and "Subsurface Facility, Emplacement Drift" subsystems), and in Q-List (BSC 2005 [DIRS 174269], Table A-1, "Engineered Barrier System" and "Subsurface Facility, Emplacement Drift" subsystems). These components include:

- Drip Shield

- Waste Package (including internals)

- Waste Form

- Cladding

- Drift Invert (ballast)

- Waste Package Emplacement Pallet

- Emplacement Drift Excavated Opening.

For the purpose of addressing FEPs in this report, processes, conditions, or components comprising or adjacent to the EBS environment that could affect the performance of EBS components are also considered. These may include the following:

- Physical and chemical environment within the drift

- Near field drift wall chemistry and conditions

- Gases or liquids within the drift

- Other emplacement materials not identified as ITWI.

Figure 6-1 shows a cross section of the drift with the EBS components identified as ITWI in Q-List (BSC 2005 [DIRS 174269], Table A-1, "Engineered Barrier System" and "Subsurface Facility, Emplacement Drift" subsystems). It also shows components determined to be relevant to addressing the EBS FEPs of this report. 


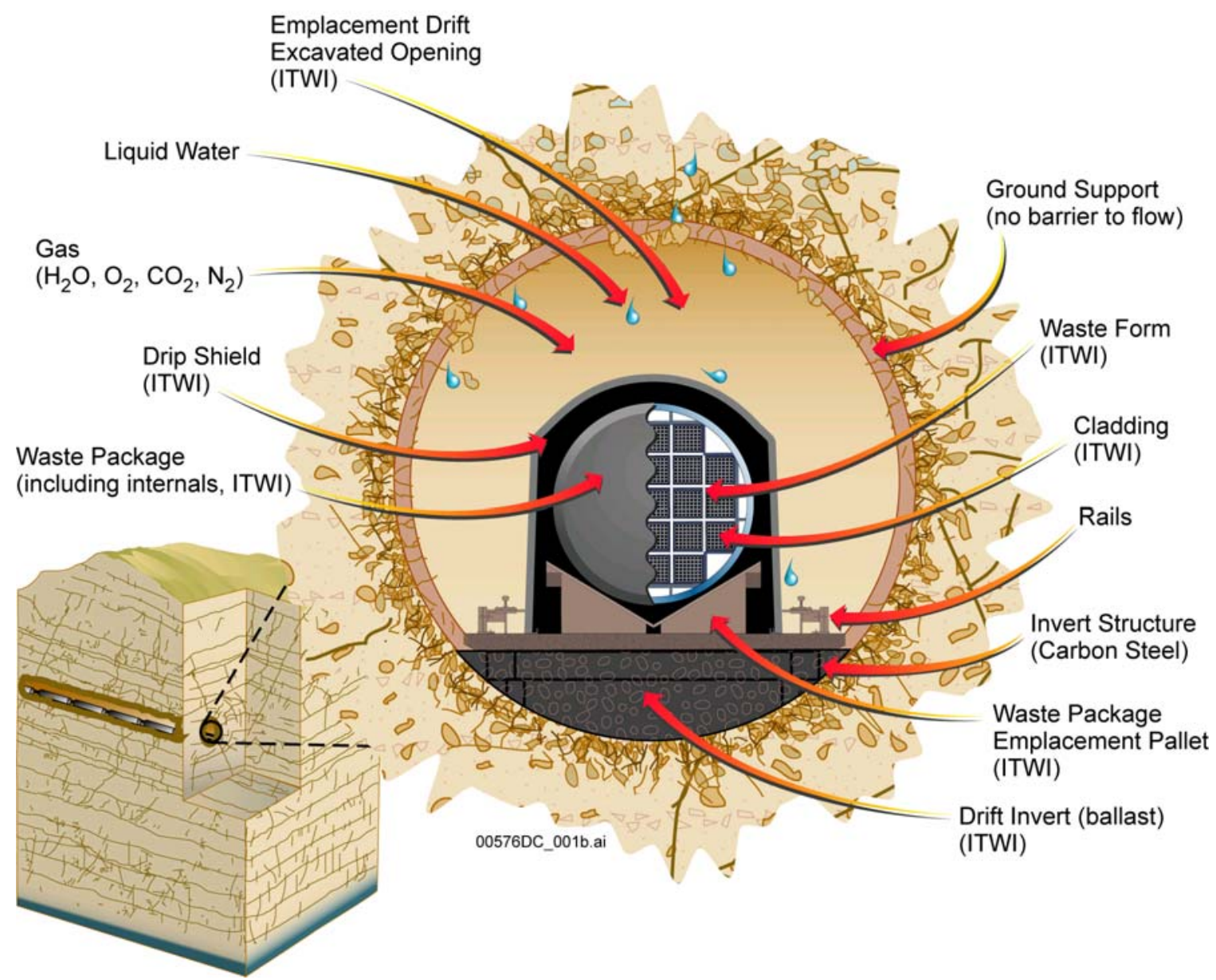

NOTE: $\quad$ Source for ITWI designations is Q-List (BSC 2005 [DIRS 174269], Table A-1, "Engineered Barrier System" and "Subsurface Facility, Emplacement Drift" subsystems).

Figure 6-1. Drift Cross-Section with Components of the EBS

This report generally addresses FEPs that include one or more of the EBS components shown in Figure 6-1. In cases where a FEP covers multiple technical areas and is shared with other FEP reports, this report provides only a partial technical basis for the screening decision as it relates to EBS FEPs concerns. Other FEPs reports that deal with components of the EBS include:

- Clad Degradation - FEPs Screening Arguments (BSC 2004 [DIRS 170019])

- Features, Events, and Processes: Disruptive Events (BSC 2005 [DIRS 173981])

- Waste-Form Features, Events, and Processes (BSC 2004 [DIRS 170020])

- Screening of Features, Events, and Processes in Drip Shield and Waste Package Degradation (BSC 2005 [DIRS 174995])

- Features, Events, and Processes in UZ Flow and Transport (BSC 2005 [DIRS 174191]). 
In some cases, if a FEP deals exclusively with an EBS component covered specifically in another FEPs report, that FEP will not be covered in this report (for example, those FEPs that appear in BSC 2004 [DIRS 170020], and do not appear in this report). The analyses presented in the screening arguments of this report frequently include everything between the drift wall and the outer shell of the waste package. The drip shield and waste package are covered in detail in Screening of Features, Events, and Processes in Drip Shield and Waste Package Degradation (BSC 2005 [DIRS 174995]). Components interior to the waste package are addressed in detail in Waste-Form Features, Events, and Processes (BSC 2004 [DIRS 170020]), and in Clad Degradation - FEPs Screening Arguments (BSC 2004 [DIRS 170019]). Some FEP screening arguments in this report include waste package internals, but impacts on those components of the EBS are typically covered in greater detail in the appropriate sharing reports. The full technical basis for these shared FEPs is addressed, collectively, by all of the sharing FEP reports. The screening arguments presented in Section 6.2 of this report provide information on sharing reports when appropriate.

Due to the nature of the FEP descriptions and the definition of the EBS, not all components of the EBS are discussed in each of the screening arguments presented in Section 6.2 of this report. The FEP description as presented in the source DTN (DTN: MO0501SEPFEPLA.001 [DIRS 172601], file FEPS_be.mdb, table "FEPS") was used as the guideline for identifying which components of the EBS were important to each FEP screening argument. Deviations in two FEP titles and descriptions in DTN: MO0501SEPFEPLA.001 [DIRS 172601] are documented in Technical Management Review Board (TMRB) Decision Proposal (TMRB-2005-047) (BSC 2005 [DIRS 174965]), and Technical Management Review Board (TMRB) Decision Proposal (TMRB-2005-050) (BSC 2005 [DIRS 174990]).EBS components specifically called out in a FEP description are addressed in the accompanying screening argument. If certain EBS components are generically identified by a FEP description, those components are addressed in the screening argument. For example, if a FEP is concerned with corrosion products within the drift, only those components that can corrode or be affected by corrosion products are addressed. Some FEPs concern the emplacement drift excavated opening and discuss the physical and chemical environment of the drift or repository without mentioning the component of the EBS specifically. Table 6-2 specifies which EBS components are discussed within each FEP screening argument in Section 6.2. 


\begin{tabular}{|c|c|c|c|c|c|}
\hline FEP Number ${ }^{\mathrm{a}}$ & FEP Name ${ }^{a}$ & FEP Description $^{\mathrm{a}}$ & $\begin{array}{c}\text { Sharing } \\
\text { Report(s) }\end{array}$ & $\begin{array}{l}\text { EBS Components } \\
\text { Specifically Addressed } \\
\text { (ITWI as identified } \\
\text { in the Q-List) }\end{array}$ & Comments \\
\hline $1.1 .02 .00 .0 \mathrm{~A}$ & $\begin{array}{l}\text { Chemical effects of } \\
\text { excavation and } \\
\text { construction in EBS }\end{array}$ & $\begin{array}{l}\text { Chemical effects associated with excavation and construction of } \\
\text { the underground regions of the repository may affect the long-term } \\
\text { behavior of the engineered and natural barriers. Excavation- } \\
\text { related effects include chemical changes to the rock and incoming } \\
\text { groundwater due to explosives residue. Excavation and other } \\
\text { construction activities could also directly cause groundwater } \\
\text { chemistry changes within the tunnel due to contaminants such as } \\
\text { diesel exhaust, explosives residues, or other organic contaminants. } \\
\text { Finally, oxidizing water introduced into the repository during } \\
\text { excavation and construction could impact repository conditions } \\
\text { and performance. }\end{array}$ & EBS & $\begin{array}{l}\text { - Emplacement Drift } \\
\text { Excavated Opening }\end{array}$ & $\begin{array}{l}\text { FEP addresses the drift } \\
\text { environment. } \\
\text { No specific components } \\
\text { assessed. See screening } \\
\text { argument/TSPA disposition for } \\
\text { details. }\end{array}$ \\
\hline $1.1 .02 .00 .0 \mathrm{~B}$ & $\begin{array}{l}\text { Mechanical effects of } \\
\text { excavation and } \\
\text { construction in EBS }\end{array}$ & $\begin{array}{l}\text { Mechanical effects associated with excavation and construction of } \\
\text { the underground regions of the repository may affect the long-term } \\
\text { behavior of the engineered and natural barriers. Excavation- } \\
\text { related effects include changes to rock properties due to boring and } \\
\text { blasting. }\end{array}$ & EBS & $\begin{array}{l}\text { - Emplacement Drift } \\
\text { Excavated Opening }\end{array}$ & $\begin{array}{l}\text { FEP addresses the drift } \\
\text { environment. }\end{array}$ \\
\hline 1.1.02.02.0A & Preclosure ventilation & $\begin{array}{l}\text { The duration of preclosure ventilation acts together with waste } \\
\text { package spacing (as per design) to control the extent of the boiling } \\
\text { front (zone of reduced water content). }\end{array}$ & $\begin{array}{l}\text { EBS } \\
\text { UZ }\end{array}$ & $\begin{array}{l}\text { - Emplacement Drift } \\
\text { Excavated Opening }\end{array}$ & $\begin{array}{l}\text { FEP addresses the drift } \\
\text { environment. } \\
\text { No specific components } \\
\text { assessed. See screening } \\
\text { argument/TSPA disposition for } \\
\text { details. }\end{array}$ \\
\hline $1.1 .02 .03 .0 \mathrm{~A}$ & Undesirable materials left & $\begin{array}{l}\text { During construction and preclosure operation of the repository, } \\
\text { unwanted materials might be left in the vicinity of the radioactive } \\
\text { waste. These materials could, to some extent, affect many long- } \\
\text { term processes in the repository from waste package corrosion to } \\
\text { radionuclide transport mechanisms. }\end{array}$ & EBS & $\begin{array}{l}\text { - Emplacement Drift } \\
\text { Excavated Opening }\end{array}$ & $\begin{array}{l}\text { FEP addresses the drift } \\
\text { environment. } \\
\text { No specific components } \\
\text { assessed. See screening } \\
\text { argument/TSPA disposition for } \\
\text { details. }\end{array}$ \\
\hline 1.1.03.01.0A & $\begin{array}{l}\text { Error in waste } \\
\text { emplacement }\end{array}$ & $\begin{array}{l}\text { Deviations from the design and/or errors in waste emplacement } \\
\text { could affect long-term performance of the repository. A specific } \\
\text { example of such an error would be erroneously emplacing the } \\
\text { waste packages in a saturated or wet zone of the repository. } \\
\text { Errors of this type would impact repository performance by affecting } \\
\text { waste package corrosion and radionuclide transport. }\end{array}$ & $\begin{array}{l}\text { EBS } \\
\text { WP }\end{array}$ & - Waste Package & None \\
\hline 1.1.03.01.0B & $\begin{array}{l}\text { Error in backfill } \\
\text { emplacement }\end{array}$ & $\begin{array}{l}\text { Deviations from the design and/or errors in the backfill } \\
\text { emplacement could affect long-term performance of the repository. }\end{array}$ & EBS & & $\begin{array}{l}\text { Backfill not in repository design, } \\
\text { individual components not } \\
\text { addressed }\end{array}$ \\
\hline
\end{tabular}




\begin{tabular}{|c|c|c|c|c|c|}
\hline FEP Number ${ }^{a}$ & FEP Name ${ }^{a}$ & FEP Description ${ }^{a}$ & $\begin{array}{c}\text { Sharing } \\
\text { Report(s) }\end{array}$ & $\begin{array}{c}\text { EBS Components } \\
\text { Specifically Addressed } \\
\text { (ITWI as identified } \\
\text { in the Q-List) }\end{array}$ & Comments \\
\hline 1.2.02.03.0A & $\begin{array}{l}\text { Fault displacement } \\
\text { damages EBS } \\
\text { components }\end{array}$ & $\begin{array}{l}\text { Movement of a fault that intersects drifts within the repository may } \\
\text { cause the EBS components to experience related movement or } \\
\text { displacement. Repository performance may be degraded by such } \\
\text { occurrences as tilting of components, component-to-component } \\
\text { contact, or drip shield separation. Fault displacement could cause } \\
\text { a failure as significant as shearing of drip shields and waste } \\
\text { packages by virtue of the relative offset across the fault, or as } \\
\text { extreme as exhumation of the waste to the surface. }\end{array}$ & $\begin{array}{l}\text { EBS } \\
\text { DE }\end{array}$ & $\begin{array}{l}\text { - Drip Shield } \\
\text { - Waste Package } \\
\text { - Invert (ballast) } \\
\text { - Waste Package } \\
\text { Emplacement Pallet } \\
\text { - Cladding }\end{array}$ & None \\
\hline 1.2.03.02.0A & $\begin{array}{l}\text { Seismic ground motion } \\
\text { damages EBS } \\
\text { components }\end{array}$ & $\begin{array}{l}\text { Seismic activity that causes repeated vibration of the EBS } \\
\text { components (drip shield, waste package, pallet, and invert) could } \\
\text { result in severe disruption of the drip shields and waste packages, } \\
\text { through vibration damage or through contact between EBS } \\
\text { components. Such damage mechanisms could lead to } \\
\text { degraded performance. }\end{array}$ & $\begin{array}{l}\text { EBS } \\
\text { DE }\end{array}$ & $\begin{array}{l}\text { - Drip Shield } \\
\text { - Waste Package } \\
\text { - Invert (ballast) } \\
\text { - Waste Package } \\
\text { Emplacement Pallet } \\
\text { - Cladding }\end{array}$ & None \\
\hline 1.2.03.02.0B & $\begin{array}{l}\text { Seismic-induced rockfall } \\
\text { damages EBS } \\
\text { components }\end{array}$ & $\begin{array}{l}\text { Seismic activity could produce jointed-rock motion and/or changes } \\
\text { in rock stress leading to enhanced rockfall that could impact drip } \\
\text { shields, waste packages, or other EBS components. }\end{array}$ & \begin{tabular}{|l} 
EBS \\
DE
\end{tabular} & $\begin{array}{l}\text { - Drip Shield } \\
\text { - Waste Package } \\
\text { - Cladding } \\
\text { - Waste Package } \\
\text { Emplacement Pallet }\end{array}$ & None \\
\hline 1.2.03.02.0C & $\begin{array}{l}\text { Seismic-induced drift } \\
\text { collapse damages EBS } \\
\text { components }\end{array}$ & $\begin{array}{l}\text { Seismic activity could produce jointed-rock motion and/or changes } \\
\text { in rock stress leading to enhanced drift collapse that could impact } \\
\text { drip shields, waste packages, or other EBS components. Possible } \\
\text { effects include both dynamic and static loading. }\end{array}$ & $\begin{array}{l}\text { EBS } \\
\text { DE }\end{array}$ & $\begin{array}{l}\text { - Drip Shield } \\
\text { - Waste Package }\end{array}$ & None \\
\hline 1.2.03.02.0D & $\begin{array}{l}\text { Seismic-induced drift } \\
\text { collapse alters in-drift } \\
\text { thermohydrology }\end{array}$ & $\begin{array}{l}\text { Seismic activity could produce jointed-rock motion and/or changes } \\
\text { in rock stress leading to enhanced drift collapse and/or rubble infill } \\
\text { throughout part or all of the drifts. Drift collapse could impact flow } \\
\text { pathways and condensation within the EBS, mechanisms for water } \\
\text { contact with EBS components, and thermal properties within } \\
\text { the EBS. }\end{array}$ & \begin{tabular}{|l} 
EBS \\
DE
\end{tabular} & $\begin{array}{l}\text { - Drip Shield } \\
\text { - Waste Package } \\
\text { - Waste Form } \\
\text { - Emplacement Drift } \\
\text { Excavated Opening }\end{array}$ & $\begin{array}{l}\text { FEP addresses the drift } \\
\text { environment. }\end{array}$ \\
\hline 1.2.03.02.0E & $\begin{array}{l}\text { Seismic-induced drift } \\
\text { collapse alters in-drift } \\
\text { chemistry }\end{array}$ & $\begin{array}{l}\text { Seismic activity could produce jointed-rock motion and/or changes } \\
\text { in rock stress leading to enhanced drift collapse and/or rubble infill } \\
\text { throughout part or all of the drifts. Drift collapse, and the } \\
\text { associated changes in seepage and in-drift thermohydrology could } \\
\text { impact in-drift chemistry. }\end{array}$ & EBS & $\begin{array}{l}\text { - Drip Shield } \\
\text { - Waste Package } \\
\text { - Waste Form } \\
\text { - Emplacement Drift } \\
\text { Excavated Opening }\end{array}$ & $\begin{array}{l}\text { FEP addresses the drift } \\
\text { environment. }\end{array}$ \\
\hline
\end{tabular}




\begin{tabular}{|c|c|c|c|c|c|}
\hline FEP Number ${ }^{a}$ & FEP Name ${ }^{a}$ & FEP Description $^{a}$ & $\begin{array}{c}\text { Sharing } \\
\text { Report(s) }\end{array}$ & $\begin{array}{c}\text { EBS Components } \\
\text { Specifically Addressed } \\
\text { (ITWl as identified } \\
\text { in the Q-List) }\end{array}$ & Comments \\
\hline $2.1 .03 .10 .0 \mathrm{~A}$ & $\begin{array}{l}\text { Advection of liquids and } \\
\text { solids through cracks in } \\
\text { the waste packages }\end{array}$ & $\begin{array}{l}\text { The presence of one or more cracks or other small openings of } \\
\text { sufficient size in a waste package may provide a pathway for the } \\
\text { advective flow of water (e.g., thin films or droplets) or solid material } \\
\text { into the waste package. The resulting presence of sufficient water } \\
\text { or solid material in the waste package may affect in-package } \\
\text { chemistry and/or criticality. Partial or full plugging of the waste } \\
\text { package cracks by chemical or physical reactions after their } \\
\text { formation (i.e., healing) could also affect water flow and } \\
\text { radionuclide transport through the waste package. Passivation by } \\
\text { corrosion products is a potential mechanism for waste } \\
\text { package healing. }\end{array}$ & EBS & - Waste Package & $\begin{array}{l}\text { FEP applies to individual } \\
\text { component. FEP addresses drift } \\
\text { environment. }\end{array}$ \\
\hline $2.1 .03 .10 .0 \mathrm{~B}$ & $\begin{array}{l}\text { Advection of liquids and } \\
\text { solids through cracks in } \\
\text { the drip shields }\end{array}$ & $\begin{array}{l}\text { The presence of one or more cracks or other small openings of } \\
\text { sufficient size in a drip shield may provide a pathway for the } \\
\text { advective flow of water (e.g., thin films or droplets) or solid material } \\
\text { through the drip shield. The resulting flux may affect drip shield } \\
\text { performance and/or subsequent dripping onto the waste packages. } \\
\text { Partial or full plugging of the drip shield cracks by chemical or } \\
\text { physical reactions after their formation (i.e., healing) could also } \\
\text { affect water flow through the drip shield. }\end{array}$ & EBS & - Drip Shield & $\begin{array}{l}\text { FEP applies to individual } \\
\text { component. FEP addresses drift } \\
\text { environment. }\end{array}$ \\
\hline 2.1.04.01.0A & Flow in the backfill & $\begin{array}{l}\text { Preferential pathways for flow and diffusion may exist within the } \\
\text { backfill and may affect long-term performance of the waste } \\
\text { packages. Backfill may not preclude hydrological, chemical, and } \\
\text { thermal interactions between waste packages within a drift. }\end{array}$ & EBS & & $\begin{array}{l}\text { Backfill not in repository design, } \\
\text { individual components not } \\
\text { addressed }\end{array}$ \\
\hline $2.1 .04 .02 .0 \mathrm{~A}$ & $\begin{array}{l}\text { Chemical properties and } \\
\text { evolution of backfill }\end{array}$ & $\begin{array}{l}\text { The chemical properties of the backfill may affect groundwater flow, } \\
\text { waste package and drip shield durability, and radionuclide transport } \\
\text { in the waste disposal region. Properties of the backfill may change } \\
\text { through time, due to processes such as alteration of minerals. }\end{array}$ & EBS & & $\begin{array}{l}\text { Backfill not in repository design, } \\
\text { individual components not } \\
\text { addressed }\end{array}$ \\
\hline $2.1 .04 .03 .0 \mathrm{~A}$ & $\begin{array}{l}\text { Erosion or dissolution } \\
\text { of backfill }\end{array}$ & $\begin{array}{l}\text { Solid material in backfill may be carried away by flowing } \\
\text { groundwater, either by erosion of particulate matter or } \\
\text { by dissolution. }\end{array}$ & EBS & & $\begin{array}{l}\text { Backfill not in repository design, } \\
\text { individual components not } \\
\text { addressed }\end{array}$ \\
\hline $2.1 .04 .04 .0 \mathrm{~A}$ & $\begin{array}{l}\text { Thermal-mechanical } \\
\text { effects of backfill }\end{array}$ & $\begin{array}{l}\text { Backfill may alter the mechanical evolution of the drift environment } \\
\text { by providing resistance to rockfall and drift collapse, by changing } \\
\text { the thermal properties of the drift, or by other means. Impacts of } \\
\text { the evolution of the properties of the backfill itself should } \\
\text { be considered. }\end{array}$ & EBS & & $\begin{array}{l}\text { Backfill not in repository design, } \\
\text { individual components not } \\
\text { addressed }\end{array}$ \\
\hline
\end{tabular}


Table 6-2. Sharing Reports and EBS Components Addressed in Each FEP (Continued)

\begin{tabular}{|c|c|c|c|c|c|}
\hline FEP Number ${ }^{a}$ & FEP Name ${ }^{a}$ & FEP Description ${ }^{a}$ & $\begin{array}{c}\text { Sharing } \\
\text { Report(s) }\end{array}$ & $\begin{array}{c}\text { EBS Components } \\
\text { Specifically Addressed } \\
\text { (ITWI as identified } \\
\text { in the Q-List) }\end{array}$ & Comments \\
\hline $2.1 .04 .05 .0 \mathrm{~A}$ & $\begin{array}{l}\text { Thermal-mechanical } \\
\text { properties and evolution } \\
\text { of backfill }\end{array}$ & $\begin{array}{l}\text { The physical properties of the backfill may affect groundwater flow, } \\
\text { waste package and drip shield durability, and radionuclide transport } \\
\text { in the waste disposal region. Properties of the backfill may change } \\
\text { through time, due to processes such as silica cementation, thermal } \\
\text { effects, and physical compaction. }\end{array}$ & EBS & & $\begin{array}{l}\text { Backfill not in repository design, } \\
\text { individual components not } \\
\text { addressed }\end{array}$ \\
\hline $2.1 .04 .09 .0 \mathrm{~A}$ & $\begin{array}{l}\text { Radionuclide transport } \\
\text { in backfill }\end{array}$ & $\begin{array}{l}\text { Radionuclide transport in the drift environment may be affected by } \\
\text { the presence of backfill. Transport (i.e., advective and diffusive } \\
\text { effects and sorption processes) of both dissolved and colloidal } \\
\text { species should be considered. }\end{array}$ & EBS & & $\begin{array}{l}\text { Backfill not in repository design, } \\
\text { individual components not } \\
\text { addressed }\end{array}$ \\
\hline $2.1 .06 .01 .0 \mathrm{~A}$ & $\begin{array}{l}\text { Chemical effects of rock } \\
\text { reinforcement and } \\
\text { cementitious materials } \\
\text { in EBS }\end{array}$ & $\begin{array}{l}\text { Degradation of ground support material (e.g., cement, rock bolts, } \\
\text { wire mesh) used for any purpose in the disposal region may affect } \\
\text { long-term performance through both chemical and physical } \\
\text { processes. Degradation may occur by physical, chemical, and } \\
\text { microbial processes. }\end{array}$ & EBS & $\begin{array}{l}\text { - Emplacement Drift } \\
\text { Excavated Opening }\end{array}$ & $\begin{array}{l}\text { FEP addresses the drift } \\
\text { environment. }\end{array}$ \\
\hline $2.1 .06 .02 .0 \mathrm{~A}$ & $\begin{array}{l}\text { Mechanical effects of rock } \\
\text { reinforcement materials in } \\
\text { EBS }\end{array}$ & $\begin{array}{l}\text { Degradation of rock bolts, wire mesh, and other materials } \\
\text { used in ground control may affect the long-term performance of } \\
\text { the repository. }\end{array}$ & EBS & $\begin{array}{l}\text { - Emplacement Drift } \\
\text { Excavated Opening }\end{array}$ & $\begin{array}{l}\text { FEP addresses the drift } \\
\text { environment. }\end{array}$ \\
\hline $2.1 .06 .04 .0 \mathrm{~A}$ & $\begin{array}{l}\text { Flow through rock } \\
\text { reinforcement materials in } \\
\text { EBS }\end{array}$ & $\begin{array}{l}\text { Groundwater flow may occur through the ground support materials } \\
\text { (e.g., wire mesh, rock bolts, grout) and liner (if present). }\end{array}$ & EBS & $\begin{array}{l}\text { - Emplacement Drift } \\
\text { Excavated Opening }\end{array}$ & $\begin{array}{l}\text { FEP addresses the drift } \\
\text { environment. }\end{array}$ \\
\hline $2.1 .06 .05 .0 \mathrm{~A}$ & $\begin{array}{l}\text { Mechanical degradation } \\
\text { of emplacement pallet }\end{array}$ & $\begin{array}{l}\text { Degradation of the materials used in the pallet supporting the waste } \\
\text { package may occur by physical processes, and may affect the } \\
\text { long-term performance of the repository. Degradation may be fast } \\
\text { (e.g., from dynamic loading) or slow (e.g., from static loading). }\end{array}$ & EBS & $\begin{array}{l}\text { - Waste Package } \\
\text { Emplacement Pallet }\end{array}$ & None \\
\hline $2.1 .06 .05 .0 \mathrm{~B}$ & $\begin{array}{l}\text { Mechanical degradation } \\
\text { of invert }\end{array}$ & $\begin{array}{l}\text { Degradation of the materials used in the invert may occur by } \\
\text { physical processes, and may affect the long-term performance of } \\
\text { the repository. Degradation may be fast (e.g., from dynamic } \\
\text { loading) or slow (e.g., from static loading). }\end{array}$ & EBS & - Invert (ballast) & None \\
\hline 2.1.06.05.0C & $\begin{array}{l}\text { Chemical degradation of } \\
\text { emplacement pallet }\end{array}$ & $\begin{array}{l}\text { Degradation of the materials used in the pallet supporting the waste } \\
\text { package may occur by chemical or microbial processes, and may } \\
\text { affect the long-term performance of the repository. }\end{array}$ & EBS & $\begin{array}{l}\text { - Waste Package } \\
\text { Emplacement Pallet }\end{array}$ & $\begin{array}{l}\text { FEP addresses the drift } \\
\text { environment. }\end{array}$ \\
\hline $2.1 .06 .05 .0 \mathrm{D}$ & $\begin{array}{l}\text { Chemical degradation } \\
\text { of invert }\end{array}$ & $\begin{array}{l}\text { Degradation of the materials used in the invert may occur by } \\
\text { chemical or microbial processes, and may affect the long-term } \\
\text { performance of the repository. }\end{array}$ & EBS & - Invert (ballast) & $\begin{array}{l}\text { FEP addresses the drift } \\
\text { environment. }\end{array}$ \\
\hline
\end{tabular}


Table 6-2. Sharing Reports and EBS Components Addressed in Each FEP (Continued)

\begin{tabular}{|c|c|c|c|c|c|}
\hline FEP Number ${ }^{a}$ & FEP Name ${ }^{a}$ & FEP Description $^{a}$ & $\begin{array}{c}\text { Sharing } \\
\text { Report(s) }\end{array}$ & $\begin{array}{l}\text { EBS Components } \\
\text { Specifically Addressed } \\
\text { (ITWI as identified } \\
\text { in the Q-List) }\end{array}$ & Comments \\
\hline $2.1 .06 .06 .0 \mathrm{~A}$ & $\begin{array}{l}\text { Effects of drip shield } \\
\text { on flow }\end{array}$ & $\begin{array}{l}\text { The drip shield will affect the amount of water reaching the waste } \\
\text { package. Effects of the drip shield on the disposal region } \\
\text { environment (for example, changes in relative humidity and } \\
\text { temperature below the shield) should be considered for both intact } \\
\text { and degraded conditions. }\end{array}$ & EBS & - Drip Shield & $\begin{array}{l}\text { FEP addresses the drift } \\
\text { environment. }\end{array}$ \\
\hline $2.1 .06 .07 .0 \mathrm{~A}$ & $\begin{array}{l}\text { Chemical effects at EBS } \\
\text { component interfaces }\end{array}$ & $\begin{array}{l}\text { Chemical effects that occur at the interfaces between materials in } \\
\text { the drift may affect the performance of the system. }\end{array}$ & EBS & $\begin{array}{l}\text { - Drip Shield } \\
\text { - Waste Package } \\
\text { - Invert (ballast) } \\
\text { - Waste Package } \\
\text { Emplacement Pallet }\end{array}$ & None \\
\hline $2.1 .06 .07 .0 \mathrm{~B}$ & $\begin{array}{l}\text { Mechanical effects at } \\
\text { EBS component } \\
\text { interfaces }\end{array}$ & $\begin{array}{l}\text { Physical effects of steady-state contact (static loading) that occur at } \\
\text { the interfaces between materials in the drift may affect the } \\
\text { performance of the system. }\end{array}$ & $\begin{array}{l}\text { EBS } \\
\text { WP }\end{array}$ & $\begin{array}{l}\text { - Drip Shield } \\
\text { - Waste Package } \\
\text { - Invert (ballast) } \\
\text { - Waste Package } \\
\text { Emplacement Pallet } \\
\end{array}$ & None \\
\hline $2.1 .07 .01 .0 \mathrm{~A}$ & Rockfall & $\begin{array}{l}\text { Rockfalls may occur with blocks that are large enough to } \\
\text { mechanically tear or rupture drip shields and/or waste packages. } \\
\text { Seismic-induced rockfall is addressed in a separate FEP. }\end{array}$ & $\begin{array}{l}\text { EBS } \\
\text { WP } \\
\text { CLAD } \\
\end{array}$ & $\begin{array}{l}\text { - Drip Shield } \\
\text { - Waste Package }\end{array}$ & None \\
\hline 2.1.07.02.0A & Drift collapse & $\begin{array}{l}\text { Partial or complete collapse of the drifts, as opposed to discrete } \\
\text { rockfall, could occur as a result of thermal effects, stresses related } \\
\text { to excavation, or other mechanisms. Drift collapse could affect the } \\
\text { stability of the engineered barriers and waste packages and/or } \\
\text { result in static loading from rock overburden. Rockfalls of small } \\
\text { blocks may produce rubble throughout part or all of the drifts. } \\
\text { Seismic-induced drift collapse is addressed in a separate FEP. }\end{array}$ & EBS & - Drip Shield & None \\
\hline $2.1 .07 .04 .0 \mathrm{~A}$ & $\begin{array}{l}\text { Hydrostatic pressure on } \\
\text { waste package }\end{array}$ & $\begin{array}{l}\text { Waste packages emplaced in the saturated zone will be subjected } \\
\text { to hydrostatic pressure in addition to stresses associated with the } \\
\text { evolution of the waste and EBS. }\end{array}$ & EBS & - Waste Package & $\begin{array}{l}\text { FEP addresses the drift } \\
\text { environment. }\end{array}$ \\
\hline 2.1.07.04.0B & $\begin{array}{l}\text { Hydrostatic pressure on } \\
\text { drip shield }\end{array}$ & $\begin{array}{l}\text { Drip shields emplaced in the saturated zone will be subjected to } \\
\text { hydrostatic pressure in addition to stresses associated with the } \\
\text { evolution of the waste and EBS. }\end{array}$ & EBS & - Drip Shield & $\begin{array}{l}\text { FEP addresses the drift } \\
\text { environment. }\end{array}$ \\
\hline $2.1 .07 .06 .0 \mathrm{~A}$ & Floor buckling & $\begin{array}{l}\text { Buckling, or heave, of the drift floor may occur in response to } \\
\text { changing stress. Floor buckling may affect the performance of EBS } \\
\text { components such as the drip shield, the invert, and the pallet. } \\
\text { Effects may include movement of EBS components and changes in } \\
\text { the topography of the surface of the drift floor and invert that may } \\
\text { affect water flow. }\end{array}$ & EBS & $\begin{array}{l}\text { - Drip Shield } \\
\text { - Waste Package } \\
\text { - Invert (ballast) } \\
\text { - Waste Package } \\
\text { Emplacement Pallet }\end{array}$ & None \\
\hline
\end{tabular}




\begin{tabular}{|c|c|c|c|c|c|}
\hline FEP Number ${ }^{a}$ & FEP Name ${ }^{a}$ & FEP Description ${ }^{a}$ & $\begin{array}{c}\text { Sharing } \\
\text { Report(s) }\end{array}$ & $\begin{array}{l}\text { EBS Components } \\
\text { Specifically Addressed } \\
\text { (ITWI as identified } \\
\text { in the Q-List) }\end{array}$ & Comments \\
\hline $2.1 .08 .01 .0 \mathrm{~B}$ & $\begin{array}{l}\text { Effects of rapid influx into } \\
\text { the repository }\end{array}$ & $\begin{array}{l}\text { Extremely rapid influx could reduce temperatures below the boiling } \\
\text { point during part or all of the thermal period. Increases in flux could } \\
\text { result from climate change, but the cause of the increase is not an } \\
\text { essential part of the FEP. }\end{array}$ & EBS & $\begin{array}{l}\text { - Drip Shield } \\
\text { - Waste Package } \\
\text { - Waste Form }\end{array}$ & None \\
\hline 2.1.08.03.0A & $\begin{array}{l}\text { Repository dry-out due } \\
\text { to waste heat }\end{array}$ & $\begin{array}{l}\text { Repository heat evaporates water from the UZ rocks near the drifts, } \\
\text { as the temperature exceeds the vaporization temperature. This } \\
\text { zone of reduced water content (reduced saturation) could migrate } \\
\text { outward during the heating phase and then migrate back to the } \\
\text { waste package as heat diffuses throughout the mountain and the } \\
\text { radioactive heat sources decay. This FEP addresses the effects of } \\
\text { dry-out within the repository drifts. }\end{array}$ & EBS & $\begin{array}{l}\text { - Emplacement Drift } \\
\text { Excavated Opening }\end{array}$ & $\begin{array}{l}\text { FEP addresses the drift } \\
\text { environment. }\end{array}$ \\
\hline 2.1.08.04.0A & $\begin{array}{l}\text { Condensation forms on } \\
\text { roofs of drifts (drift-scale } \\
\text { cold traps) }\end{array}$ & $\begin{array}{l}\text { Emplacement of waste in drifts creates thermal gradients within the } \\
\text { repository. Such thermal gradients can lead to drift-scale cold traps } \\
\text { characterized by latent heat transfer from warmer to cooler } \\
\text { locations. This mechanism can result in condensation forming on } \\
\text { the roof or other parts of the drifts, leading to enhanced dripping on } \\
\text { the drip shields, waste packages, or exposed waste material. }\end{array}$ & EBS & $\begin{array}{l}\text { - Emplacement Drift } \\
\text { Excavated Opening }\end{array}$ & $\begin{array}{l}\text { FEP addresses the drift } \\
\text { environment. }\end{array}$ \\
\hline $2.1 .08 .04 .0 \mathrm{~B}$ & $\begin{array}{l}\text { Condensation forms } \\
\text { at repository edges } \\
\text { (repository-scale } \\
\text { cold traps) }\end{array}$ & $\begin{array}{l}\text { Emplacement of waste in drifts creates thermal gradients within the } \\
\text { repository. Such thermal gradients can lead to repository-scale } \\
\text { cold traps characterized by latent heat transfer from warmer to } \\
\text { cooler locations. This mechanism can result in condensation } \\
\text { forming at repository edges or elsewhere in the EBS, leading to } \\
\text { enhanced dripping on the drip shields, waste packages, or exposed } \\
\text { waste material. }\end{array}$ & EBS & $\begin{array}{l}\text { - Emplacement Drift } \\
\text { Excavated Opening }\end{array}$ & $\begin{array}{l}\text { FEP addresses the drift } \\
\text { environment. }\end{array}$ \\
\hline 2.1.08.05.0A & Flow through invert & $\begin{array}{l}\text { The invert, a porous material consisting of crushed tuff, separates } \\
\text { the waste package from the bottom of the drift. Flow and transport } \\
\text { through and around the invert can influence radionuclide release to } \\
\text { the UZ. }\end{array}$ & EBS & - Invert (ballast) & None \\
\hline $2.1 .08 .06 .0 \mathrm{~A}$ & $\begin{array}{l}\text { Capillary effects (wicking) } \\
\text { in EBS }\end{array}$ & $\begin{array}{l}\text { Capillary rise, or wicking, is a potential mechanism for water to } \\
\text { move through the waste and EBS. }\end{array}$ & EBS & $\begin{array}{l}\text { - Waste Package } \\
\text { - Invert (ballast) } \\
\text { - Emplacement Drift }\end{array}$ & None \\
\hline $2.1 .08 .07 .0 \mathrm{~A}$ & $\begin{array}{l}\text { Unsaturated flow in } \\
\text { the EBS }\end{array}$ & $\begin{array}{l}\text { Unsaturated flow may occur along preferential pathways in the } \\
\text { waste and EBS. Physical and chemical properties of the EBS and } \\
\text { waste form, in both intact and degraded states, should be } \\
\text { considered in evaluating pathways. }\end{array}$ & EBS & $\begin{array}{l}\text { - Emplacement Drift } \\
\text { Excavated Opening } \\
\text { - Drip Shield } \\
\text { - Waste Package } \\
\text { - Invert (ballast) } \\
\text { - Waste Package } \\
\text { Emplacement Pallet }\end{array}$ & None \\
\hline
\end{tabular}


Table 6-2. Sharing Reports and EBS Components Addressed in Each FEP (Continued)

\begin{tabular}{|c|c|c|c|c|c|}
\hline FEP Number ${ }^{a}$ & FEP Name ${ }^{a}$ & FEP Description ${ }^{\mathrm{a}}$ & $\begin{array}{c}\text { Sharing } \\
\text { Report(s) }\end{array}$ & $\begin{array}{l}\text { EBS Components } \\
\text { Specifically Addressed } \\
\text { (ITWI as identified } \\
\text { in the Q-List) }\end{array}$ & Comments \\
\hline 2.1.08.09.0A & Saturated flow in the EBS & $\begin{array}{l}\text { Saturated flow and radionuclide transport may occur along } \\
\text { preferential pathways in the waste and EBS. Physical and } \\
\text { chemical properties of the EBS and waste form, in both intact and } \\
\text { degraded states, should be considered in evaluating pathways. }\end{array}$ & EBS & - Invert (ballast) & None \\
\hline 2.1.08.11.0A & $\begin{array}{l}\text { Repository resaturation } \\
\text { due to waste cooling }\end{array}$ & $\begin{array}{l}\text { Following the peak thermal period, water in the condensation cap } \\
\text { may flow downward, resaturating the geosphere dry-out zone and } \\
\text { flowing into the drifts. This may lead to an increase in water } \\
\text { content and/or resaturation in the repository. }\end{array}$ & EBS & $\begin{array}{l}\text { - Emplacement Drift } \\
\text { Excavated Opening }\end{array}$ & $\begin{array}{l}\text { FEP addresses the drift } \\
\text { environment. }\end{array}$ \\
\hline $2.1 .08 .12 .0 \mathrm{~A}$ & $\begin{array}{l}\text { Induced hydrologic } \\
\text { changes in invert }\end{array}$ & $\begin{array}{l}\text { Drainage in the drifts may be altered by plugging of fractures or } \\
\text { floor buckling. Possible effects include wetting or ponding in the } \\
\text { invert until the water level reaches the fractures in the wall or until } \\
\text { there is sufficient hydraulic head to clear the fractures. Wetting or } \\
\text { ponding could provide a continuing source of water vapor for } \\
\text { interaction with the drip shields, waste packages, and } \\
\text { their supports. }\end{array}$ & EBS & - Invert (ballast) & $\begin{array}{l}\text { FEP applies to individual } \\
\text { component. }\end{array}$ \\
\hline $2.1 .08 .14 .0 \mathrm{~A}$ & $\begin{array}{l}\text { Condensation on } \\
\text { underside of drip shield }\end{array}$ & $\begin{array}{l}\text { Condensation of water on the underside of the drip shield may } \\
\text { affect the waste package hydrologic and chemical environment. }\end{array}$ & EBS & $\begin{array}{l}\text { - Emplacement Drift } \\
\text { Excavated Opening } \\
\text { - Drip Shield }\end{array}$ & $\begin{array}{l}\text { FEP addresses the drift } \\
\text { environment. }\end{array}$ \\
\hline 2.1.08.15.0A & $\begin{array}{l}\text { Consolidation of } \\
\text { EBS components }\end{array}$ & $\begin{array}{l}\text { Physical and chemical degradation of the drip shield, invert, waste } \\
\text { form, and waste package may cause collapse and settlement within } \\
\text { the repository. This consolidation may affect the development of } \\
\text { the chemical environment and, therefore, the radionuclide transport } \\
\text { out of the EBS. }\end{array}$ & EBS & $\begin{array}{l}\text { - Drip Shield } \\
\text { - Waste Package } \\
\text { - Invert (ballast) } \\
\text { - Waste Form }\end{array}$ & None \\
\hline $2.1 .09 .01 .0 \mathrm{~A}$ & $\begin{array}{l}\text { Chemical characteristics } \\
\text { of water in drifts }\end{array}$ & $\begin{array}{l}\text { When flow in the drifts is re-established following the peak thermal } \\
\text { period, water may have chemical characteristics influenced by the } \\
\text { near-field host rock and EBS. Specifically, the water chemistry (pH } \\
\text { and dissolved species in the groundwater) may be affected by } \\
\text { interactions with cementitious materials or steel used in the } \\
\text { disposal region. These point source contaminated waters may } \\
\text { coalesce to form a larger volume of contaminated water. This } \\
\text { altered groundwater is referred to as the carrier plume because } \\
\text { dissolution and transport will occur in this altered chemical } \\
\text { environment as contaminants move through the EBS, and down } \\
\text { into the unsaturated zone. (Note: there is no defining limit as to } \\
\text { what volume of contaminated water constitutes a plume.) }\end{array}$ & EBS & $\begin{array}{l}\text { - Emplacement Drift } \\
\text { Excavated Opening }\end{array}$ & $\begin{array}{l}\text { FEP addresses the drift } \\
\text { environment. }\end{array}$ \\
\hline
\end{tabular}




\begin{tabular}{|c|c|c|c|c|c|}
\hline FEP Number ${ }^{a}$ & FEP Name ${ }^{a}$ & FEP Description ${ }^{a}$ & $\begin{array}{c}\text { Sharing } \\
\text { Report(s) }\end{array}$ & $\begin{array}{l}\text { EBS Components } \\
\text { Specifically Addressed } \\
\text { (ITWI as identified } \\
\text { in the Q-List) }\end{array}$ & Comments \\
\hline $2.1 .09 .02 .0 \mathrm{~A}$ & $\begin{array}{l}\text { Chemical interaction with } \\
\text { corrosion products }\end{array}$ & $\begin{array}{l}\text { Corrosion products produced during degradation of the waste form, } \\
\text { metallic portions of the waste package, and metals in the drift (i.e., } \\
\text { rock bolts, steel in the invert, gantry rails) may affect the } \\
\text { mobilization and transport of radionuclides. Corrosion products } \\
\text { may facilitate sorption/desorption and co-precipitation/dissolution } \\
\text { processes. Corrosion products may form a "rind" around the fuel } \\
\text { that could (1) restrict the availability of water for dissolution of } \\
\text { radionuclides or (2) inhibit advective or diffusive transport of water } \\
\text { and radionuclides from the waste form to the EBS. Corrosion } \\
\text { products also have the potential to retard the transport of } \\
\text { radionuclides to the EBS. Finally, corrosion products may alter the } \\
\text { local chemistry, possibly enhancing dissolution rates for specific } \\
\text { waste forms, or altering radionuclide solubility. }\end{array}$ & \begin{tabular}{|l} 
EBS \\
WF
\end{tabular} & $\begin{array}{l}\text { - Waste Package } \\
\text { - Waste Form }\end{array}$ & None \\
\hline $2.1 .09 .03 .0 \mathrm{C}$ & $\begin{array}{l}\text { Volume increase of } \\
\text { corrosion products } \\
\text { impacts other EBS } \\
\text { components }\end{array}$ & $\begin{array}{l}\text { Corrosion products have a higher molar volume than the intact, } \\
\text { uncorroded material. This FEP addresses volume increase in all } \\
\text { EBS components other than waste package, waste form, and } \\
\text { cladding. Increases in volume during corrosion of steel in the invert } \\
\text { may change the stress state or structural integrity of the invert. }\end{array}$ & EBS & $\begin{array}{l}\text { - Drip Shield } \\
\text { - Invert (ballast) }\end{array}$ & $\begin{array}{l}\text { Waste package, waste form, and } \\
\text { cladding specifically excluded in } \\
\text { FEP description. }\end{array}$ \\
\hline $2.1 .09 .05 .0 \mathrm{~A}$ & $\begin{array}{l}\text { Sorption of dissolved } \\
\text { radionuclides in EBS }\end{array}$ & $\begin{array}{l}\text { Sorption of dissolved radionuclides within the waste package may } \\
\text { affect the aqueous concentrations of radionuclides released to } \\
\text { the EBS. }\end{array}$ & EBS & $\begin{array}{l}\text { - Waste Package } \\
\text { - Invert (ballast) }\end{array}$ & None \\
\hline $2.1 .09 .06 .0 \mathrm{~B}$ & $\begin{array}{l}\text { Reduction-oxidation } \\
\text { potential in drifts }\end{array}$ & $\begin{array}{l}\text { The redox potential in the EBS influences the oxidation of the in- } \\
\text { drift materials and the in-drift solubility of radionuclide species. } \\
\text { Local variations in the in-drift redox potential can occur. }\end{array}$ & EBS & $\begin{array}{l}\text { - Emplacement Drift } \\
\text { Excavated Opening }\end{array}$ & $\begin{array}{l}\text { FEP addresses the drift } \\
\text { environment. }\end{array}$ \\
\hline $2.1 .09 .07 .0 \mathrm{~B}$ & Reaction kinetics in drifts & $\begin{array}{l}\text { Chemical reactions, such as radionuclide dissolution/precipitation } \\
\text { reactions and reactions controlling the reduction-oxidation state, } \\
\text { may not be at equilibrium in the drifts. }\end{array}$ & EBS & $\begin{array}{l}\text { - Emplacement Drift } \\
\text { Excavated Opening }\end{array}$ & $\begin{array}{l}\text { FEP addresses the drift } \\
\text { environment. }\end{array}$ \\
\hline $2.1 .09 .08 .0 \mathrm{~A}$ & $\begin{array}{l}\text { Diffusion of dissolved } \\
\text { radionuclides in EBS }\end{array}$ & $\begin{array}{l}\text { Radionuclide transport of dissolved radionuclides by diffusion, in } \\
\text { response to chemical gradients, may occur within the EBS. } \\
\text { Physical and chemical properties of the EBS and waste form, in } \\
\text { both intact and degraded states, should be considered in } \\
\text { evaluating diffusive transport. }\end{array}$ & EBS & $\begin{array}{l}\text { - Waste Package } \\
\text { - Invert (ballast) } \\
\text { - Waste Package } \\
\text { Emplacement Pallet } \\
\text { - Waste Form } \\
\text { - Cladding }\end{array}$ & None \\
\hline 2.1.09.08.0B & $\begin{array}{l}\text { Advection of dissolved } \\
\text { radionuclides in EBS }\end{array}$ & $\begin{array}{l}\text { Radionuclide transport of dissolved radionuclides by advection with } \\
\text { the flowing groundwater may occur within the EBS. Physical and } \\
\text { chemical properties of the EBS and waste form, in both intact and } \\
\text { degraded states, should be considered in evaluating } \\
\text { advective transport. }\end{array}$ & EBS & $\begin{array}{l}\text { - Drip Shield } \\
\text { - Waste Package } \\
\text { - Invert (ballast) } \\
\text { - Waste Package } \\
\text { Emplacement Pallet } \\
\text { - Waste Form } \\
\text { - Cladding }\end{array}$ & None \\
\hline
\end{tabular}


Table 6-2. Sharing Reports and EBS Components Addressed in Each FEP (Continued)

\begin{tabular}{|c|c|c|c|c|c|}
\hline FEP Number ${ }^{a}$ & FEP Name ${ }^{a}$ & FEP Description $^{a}$ & $\begin{array}{c}\text { Sharing } \\
\text { Report(s) }\end{array}$ & $\begin{array}{c}\text { EBS Components } \\
\text { Specifically Addressed } \\
\text { (ITWl as identified } \\
\text { in the Q-List) }\end{array}$ & Comments \\
\hline $2.1 .09 .19 .0 \mathrm{~A}$ & $\begin{array}{l}\text { Sorption of colloids } \\
\text { in EBS }\end{array}$ & $\begin{array}{l}\text { Interactions between radionuclide-bearing colloids and the waste } \\
\text { and EBS may result in retardation of the colloids during transport } \\
\text { by sorption mechanisms. }\end{array}$ & EBS & $\begin{array}{l}\text { - Waste Package } \\
\text { - Invert (ballast) } \\
\text { - Waste Form }\end{array}$ & None \\
\hline $2.1 .09 .19 .0 \mathrm{~B}$ & $\begin{array}{l}\text { Advection of colloids } \\
\text { in EBS }\end{array}$ & $\begin{array}{l}\text { Transport of radionuclide-bearing colloids in the waste and EBS } \\
\text { may occur by advection. }\end{array}$ & EBS & $\begin{array}{l}\text { - Waste Package } \\
\text { - Invert (ballast) } \\
\text { - Waste Package } \\
\text { Emplacement Pallet } \\
\text { - Waste Form }\end{array}$ & None \\
\hline $2.1 .09 .20 .0 \mathrm{~A}$ & $\begin{array}{l}\text { Filtration of colloids } \\
\text { in EBS }\end{array}$ & $\begin{array}{l}\text { Filtration processes may affect transport of radionuclide-bearing } \\
\text { colloids in the waste and EBS. Filtration includes physical and } \\
\text { electrostatic processes in pores and fractures of natural and } \\
\text { anthropogenic materials, such as concrete and the joints between } \\
\text { invert segments. }\end{array}$ & EBS & $\begin{array}{l}\text { - Waste Package } \\
\text { - Invert (ballast) } \\
\text { - Waste Form }\end{array}$ & None \\
\hline 2.1.09.21.0A & $\begin{array}{l}\text { Transport of particles } \\
\text { larger than colloids } \\
\text { in EBS }\end{array}$ & $\begin{array}{l}\text { Groundwater flow through the waste could remove radionuclide- } \\
\text { bearing particles by a rinse mechanism. Particles of radionuclide- } \\
\text { bearing material larger than colloids could be entrained in } \\
\text { suspension and then be transported in water flowing through the } \\
\text { waste and EBS. }\end{array}$ & EBS & $\begin{array}{l}\text { - Waste Package } \\
\text { - Waste Form }\end{array}$ & None \\
\hline $2.1 .09 .22 .0 \mathrm{~A}$ & $\begin{array}{l}\text { Sorption of colloids at } \\
\text { air-water interface }\end{array}$ & $\begin{array}{l}\text { Colloids may be sorbed irreversibly at the gas-water interface } \\
\text { under partially saturated conditions. }\end{array}$ & EBS & $\begin{array}{l}\text { - Waste Package } \\
\text { - Invert (ballast) }\end{array}$ & None \\
\hline $2.1 .09 .24 .0 \mathrm{~A}$ & $\begin{array}{l}\text { Diffusion of colloids } \\
\text { in EBS }\end{array}$ & $\begin{array}{l}\text { Colloidal particles, together with any associated actinides, that are } \\
\text { sufficiently small may be transported through the EBS by diffusion. }\end{array}$ & EBS & $\begin{array}{l}\text { - Waste Package } \\
\text { - Invert (ballast) } \\
\text { - Waste Package } \\
\text { Emplacement Pallet } \\
\text { - Waste Form } \\
\text { - Cladding } \\
\text { - Drip Shield }\end{array}$ & None \\
\hline $2.1 .09 .26 .0 \mathrm{~A}$ & $\begin{array}{l}\text { Gravitational settling of } \\
\text { colloids in EBS }\end{array}$ & $\begin{array}{l}\text { Over the relatively short transport distances within the waste } \\
\text { package, colloidal particles may experience gravitational settling, } \\
\text { thereby inhibiting transport. }\end{array}$ & EBS & - Waste Package & None \\
\hline $2.1 .09 .27 .0 \mathrm{~A}$ & $\begin{array}{l}\text { Coupled effects on } \\
\text { radionuclide transport } \\
\text { in EBS }\end{array}$ & \begin{tabular}{|l|} 
Repository induced changes to the physical and chemical \\
properties of the EBS and waste form may be important for \\
evaluating radionuclide transport in the EBS. The existence of \\
chemical gradients within the disposal system, resulting from \\
repository material, waste emplacement, and corrosion products, \\
may influence the transport of dissolved and colloidal species. This \\
could include: geochemical reactions that move (pump) \\
radionuclides; effects on advection, diffusion, and sorption within \\
and through failed waste packages; and microbial and \\
electrochemical effects.
\end{tabular} & EBS & $\begin{array}{l}\text { - Drip Shield } \\
\text { - Waste Package } \\
\text { - Invert (ballast) } \\
\text { - Waste Form }\end{array}$ & None \\
\hline
\end{tabular}


Table 6-2. Sharing Reports and EBS Components Addressed in Each FEP (Continued)

\begin{tabular}{|c|c|c|c|c|c|}
\hline FEP Number ${ }^{\mathrm{a}}$ & FEP Name ${ }^{a}$ & FEP Description ${ }^{a}$ & $\begin{array}{c}\text { Sharing } \\
\text { Report(s) }\end{array}$ & \begin{tabular}{|c|} 
EBS Components \\
Specifically Addressed \\
(ITWI as identified \\
in the Q-List)
\end{tabular} & Comments \\
\hline $2.1 .09 .28 .0 \mathrm{~A}$ & $\begin{array}{l}\text { Localized corrosion on } \\
\text { waste package outer } \\
\text { surface due to } \\
\text { deliquescence }^{\text {b }}\end{array}$ & $\begin{array}{l}\text { Salt-containing dust, which could accumulate on the waste } \\
\text { package surface during the preclosure ventilation period, can } \\
\text { absorb moisture from the drift atmosphere, even at low relative } \\
\text { humidity, dissolving the salt and creating concentrated aqueous } \\
\text { solutions. This deliquescence process may result in localized } \\
\text { surface chemistry that could cause penetration of the waste } \\
\text { package outer barrier by localized corrosion. }\end{array}$ & $\begin{array}{l}\text { EBS } \\
\text { WP }^{c}\end{array}$ & - Waste Package & $\begin{array}{l}\text { FEP applies to individual } \\
\text { component. }\end{array}$ \\
\hline $2.1 .09 .28 .0 \mathrm{~B}$ & $\begin{array}{l}\text { Localized corrosion on } \\
\text { drip shield surfaces due } \\
\text { to deliquescence }\end{array}$ & $\begin{array}{l}\text { Salt-containing dust, which could accumulate on the drip shield } \\
\text { surface during the preclosure ventilation period, can absorb } \\
\text { moisture from the drift atmosphere, even at low relative humidity, } \\
\text { dissolving the salt and creating concentrated aqueous solutions. } \\
\text { This deliquescence process may result in localized surface } \\
\text { chemistry that could cause penetration of the drip shield surface by } \\
\text { localized corrosion. }\end{array}$ & EBS & - Drip Shield & $\begin{array}{l}\text { FEP applies to individual } \\
\text { component. }\end{array}$ \\
\hline 2.1.10.01.0A & Microbial activity in EBS & $\begin{array}{l}\text { Biological activity is important to consider because of the potential } \\
\text { impact on aqueous chemical conditions within the waste and EBS. } \\
\text { In deep subsurface environments, biological activity is limited to } \\
\text { microbiological activity and may include effects of natural and } \\
\text { anthropogenic bacteria (e.g., anaerobic, methanogenic, sulfate } \\
\text { reducers, etc.), protozoans, yeast, viruses, and algae. This FEP } \\
\text { addresses a broad range of effects of biological impacts, including } \\
\text { the effects of microbes on corrosion of waste packages, cladding, } \\
\text { and waste form; bioreduction of multivalent contaminants, metals, } \\
\text { and sulfate; generation of organic complexants and gases as } \\
\text { metabolic by-products; and the formation of biofilms and their } \\
\text { impact on transport. }\end{array}$ & EBS & 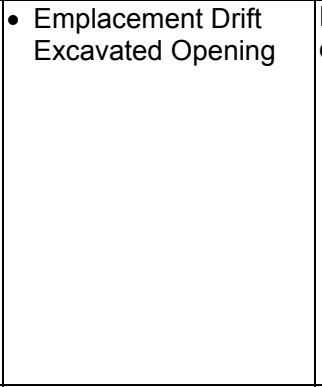 & $\begin{array}{l}\text { FEP addresses the Drift } \\
\text { environment. }\end{array}$ \\
\hline $2.1 .11 .01 .0 \mathrm{~A}$ & Heat generation in EBS & $\begin{array}{l}\text { Temperature in the waste and EBS will vary through time. Heat } \\
\text { from radioactive decay will be the primary cause of temperature } \\
\text { change, but other factors to be considered in determining the } \\
\text { temperature history include the in-situ geothermal gradient, thermal } \\
\text { properties of the rock, EBS, and waste materials, hydrological } \\
\text { effects, and the possibility of exothermic reactions. Considerations } \\
\text { of the heat generated by radioactive decay should take different } \\
\text { properties of different waste types, including DSNF, into account. }\end{array}$ & EBS & $\begin{array}{l}\text { - Emplacement Drift } \\
\text { Excavated Opening } \\
\text { - Drip Shield } \\
\text { - Waste Package } \\
\text { - Waste Form }\end{array}$ & None \\
\hline $2.1 .11 .02 .0 \mathrm{~A}$ & $\begin{array}{l}\text { Non-uniform heat } \\
\text { distribution in EBS }\end{array}$ & $\begin{array}{l}\text { Uneven heating and cooling at edges of the repository may lead to } \\
\text { non-uniform thermal effects during both the thermal peak and the } \\
\text { cool-down period. }\end{array}$ & EBS & 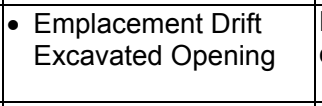 & $\begin{array}{l}\text { FEP addresses the drift } \\
\text { environment. }\end{array}$ \\
\hline $2.1 .11 .03 .0 \mathrm{~A}$ & $\begin{array}{l}\text { Exothermic reactions in } \\
\text { the EBS }\end{array}$ & $\begin{array}{l}\text { Exothermic reactions liberate heat and will alter the temperature of } \\
\text { the disposal system and affect the properties of the repository and } \\
\text { surrounding materials. Examples of possible exothermic reactions } \\
\text { include oxidation of uranium metal fuels such as represented by } \\
\text { N-Reactor fuels and hydration of concrete used in the } \\
\text { underground environment. }\end{array}$ & $\begin{array}{l}\text { EBS } \\
\text { WF }\end{array}$ & $\begin{array}{l}\text { - Waste Package } \\
\text { - Waste Form }\end{array}$ & None \\
\hline
\end{tabular}




\begin{tabular}{|c|c|c|c|c|c|}
\hline FEP Number ${ }^{\mathrm{a}}$ & FEP Name ${ }^{a}$ & FEP Description ${ }^{a}$ & $\begin{array}{c}\text { Sharing } \\
\text { Report(s) }\end{array}$ & $\begin{array}{c}\text { EBS Components } \\
\text { Specifically Addressed } \\
\text { (ITWI as identified } \\
\text { in the Q-List) }\end{array}$ & Comments \\
\hline $2.1 .11 .07 .0 \mathrm{~A}$ & $\begin{array}{l}\text { Thermal expansion/ } \\
\text { stress of in-drift EBS } \\
\text { components }\end{array}$ & $\begin{array}{l}\text { Repository heat at Yucca Mountain could result in thermally } \\
\text { induced stress changes that would affect the mechanical and } \\
\text { chemical evolution of the repository. These stress changes could } \\
\text { affect the EBS components, thus causing the formation of } \\
\text { pathways for groundwater flow through the EBS or altering and/or } \\
\text { enhancing existing pathways. Relevant processes include changes } \\
\text { in physical properties of the drip shields, waste packages, pallet, } \\
\text { and invert. }\end{array}$ & $\begin{array}{l}\text { EBS } \\
\text { WP }\end{array}$ & $\begin{array}{l}\text { - Drip Shield } \\
\text { - Waste Package } \\
\text { - Invert (ballast) } \\
\text { - Waste Package } \\
\text { Emplacement Pallet }\end{array}$ & None \\
\hline $2.1 .11 .08 .0 \mathrm{~A}$ & $\begin{array}{l}\text { Thermal effects on } \\
\text { chemistry and microbial } \\
\text { activity in the EBS }\end{array}$ & $\begin{array}{l}\text { Temperature changes may affect chemical and microbial } \\
\text { processes in the waste and EBS. }\end{array}$ & \begin{tabular}{|l|} 
EBS \\
WF
\end{tabular} & $\begin{array}{l}\text { Emplacement Drift } \\
\text { Excavated Opening }\end{array}$ & $\begin{array}{l}\text { FEP addresses the drift } \\
\text { environment. }\end{array}$ \\
\hline 2.1.11.09.0A & $\begin{array}{l}\text { Thermal effects on flow } \\
\text { in the EBS }\end{array}$ & $\begin{array}{l}\text { High temperatures in the EBS may influence seepage into, and } \\
\text { flow within, the waste and EBS. Thermally-induced changes to } \\
\text { fluid saturation and/or relative humidity could influence in-package } \\
\text { chemistry. Thermal gradients in the repository could lead to } \\
\text { localized accumulation of moisture. Wet zones could form below } \\
\text { the areas of moisture accumulation. }\end{array}$ & EBS & $\begin{array}{l}\text { - Emplacement Drift } \\
\text { Excavated Opening } \\
\text { - Drip Shield } \\
\text { - Waste Package } \\
\text { - Invert }\end{array}$ & None \\
\hline 2.1.11.09.0C & $\begin{array}{l}\text { Thermally driven flow } \\
\text { (convection) in drifts }\end{array}$ & $\begin{array}{l}\text { Temperature differentials may result in convective flow in the EBS. } \\
\text { Convective flow within the drifts could influence in-drift chemistry. }\end{array}$ & EBS & $\begin{array}{l}\text { - Emplacement Drift } \\
\text { Excavated Opening } \\
\text { - Waste Package }\end{array}$ & None \\
\hline $2.1 .11 .10 .0 \mathrm{~A}$ & $\begin{array}{l}\text { Thermal effects on } \\
\text { transport in EBS }\end{array}$ & $\begin{array}{l}\text { Temperature changes in the repository may influence advection, } \\
\text { diffusion, and sorption in the EBS. The Soret effect is a diffusion } \\
\text { process caused by a thermal gradient. In liquids having both light } \\
\text { and heavy molecules (or ions) and a temperature or thermal } \\
\text { gradient, the heavier solute molecules tend to concentrate in the } \\
\text { colder region. Temperature differences in the waste and EBS may } \\
\text { result in a component of diffusive solute flux that is proportional to } \\
\text { the temperature gradient. }\end{array}$ & EBS & $\begin{array}{l}\text { - Emplacement Drift } \\
\text { Excavated Opening }\end{array}$ & $\begin{array}{l}\text { FEP addresses the drift } \\
\text { environment. }\end{array}$ \\
\hline \begin{tabular}{|l|}
$2.1 .12 .01 .0 \mathrm{~A}$ \\
\end{tabular} & $\begin{array}{l}\text { Gas generation } \\
\text { (repository pressurization) }\end{array}$ & $\begin{array}{l}\text { Gas generation in the repository might lead to pressurization of the } \\
\text { repository, produce multiphase flow, and affect radionuclide } \\
\text { transport. This FEP addresses repository pressurization. }\end{array}$ & EBS & $\begin{array}{l}\text { - Waste Package } \\
\text { - Waste Form }\end{array}$ & None \\
\hline $2.1 .12 .02 .0 \mathrm{~A}$ & $\begin{array}{l}\text { Gas generation }(\mathrm{He}) \text { from } \\
\text { waste form decay }\end{array}$ & $\begin{array}{l}\text { Helium }(\mathrm{He}) \text { gas production may occur by alpha decay in the } \\
\text { waste. Helium production might cause local pressure buildup in } \\
\text { cracks in the fuel and in the void between fuel and cladding, } \\
\text { leading to cladding and waste package failure. }\end{array}$ & $\begin{array}{l}\text { EBS } \\
\text { CLAD }\end{array}$ & $\begin{array}{l}\text { - Waste Package } \\
\text { - Cladding }\end{array}$ & None \\
\hline
\end{tabular}




\begin{tabular}{|c|c|c|c|c|c|}
\hline FEP Number ${ }^{a}$ & FEP Name ${ }^{a}$ & FEP Description $^{a}$ & $\begin{array}{c}\text { Sharing } \\
\text { Report(s) }\end{array}$ & $\begin{array}{c}\text { EBS Components } \\
\text { Specifically Addressed } \\
\text { (ITWI as identified } \\
\text { in the Q-List) }\end{array}$ & Comments \\
\hline $2.1 .12 .03 .0 \mathrm{~A}$ & $\begin{array}{l}\text { Gas generation }\left(\mathrm{H}_{2}\right) \text { from } \\
\text { waste package corrosion }\end{array}$ & $\begin{array}{l}\text { Gas generation can affect the mechanical behavior of the host rock } \\
\text { and engineered barriers, chemical conditions, and fluid flow, and, } \\
\text { as a result, the transport of radionuclides. Gas generation due to } \\
\text { oxic corrosion of waste packages, cladding, and/or structural } \\
\text { materials will occur at early times following closure of the } \\
\text { repository. Anoxic corrosion may follow the oxic phase if all oxygen } \\
\text { is depleted. The formation of a gas phase around the waste } \\
\text { package may exclude oxygen from the iron, thus inhibiting further } \\
\text { corrosion. }\end{array}$ & $\begin{array}{l}\text { EBS } \\
\text { CLAD } \\
\text { WP }\end{array}$ & $\begin{array}{l}\text { - Drip Shield } \\
\text { - Waste Package } \\
\text { - Cladding }\end{array}$ & None \\
\hline $2.1 .12 .04 .0 \mathrm{~A}$ & $\begin{array}{l}\text { Gas generation }\left(\mathrm{CO}_{2},\right. \\
\left.\mathrm{CH}_{4}, \mathrm{H}_{2} \mathrm{~S}\right) \text { from microbial } \\
\text { degradation }\end{array}$ & $\begin{array}{l}\text { Microbes are known to produce inorganic acids, methane, organic } \\
\text { byproducts, carbon dioxide, and other chemical species that could } \\
\text { change the longevity of materials in the repository and the transport } \\
\text { of radionuclides from the near-field. The rate of microbial gas } \\
\text { production will depend on the nature of the microbial populations } \\
\text { established, the prevailing conditions (temperature, pressure, } \\
\text { geochemical conditions), and the organic or inorganic substrates } \\
\text { present. Initial analysis indicates the most important source of } \\
\text { nutrient in the YMP repository will be metals. Other possible } \\
\text { nutrients include cellulosic material, plastics, and synthetic } \\
\text { materials. Minimal amounts of organics are mandated } \\
\text { by regulation. }\end{array}$ & \begin{tabular}{|l} 
EBS \\
WF
\end{tabular} & $\begin{array}{l}\text { - Emplacement Drift } \\
\text { Excavated Opening }\end{array}$ & $\begin{array}{l}\text { FEP addresses the drift } \\
\text { environment. }\end{array}$ \\
\hline $2.1 .12 .06 .0 \mathrm{~A}$ & Gas transport in EBS & $\begin{array}{l}\text { Gas in the waste and EBS could affect the long-term performance } \\
\text { of the disposal system. Radionuclides may be transported as } \\
\text { gases or in gases. Gas bubbles may affect flowpaths, and } \\
\text { two-phase flow conditions may be important. }\end{array}$ & EBS & $\begin{array}{l}\text { - Emplacement Drift } \\
\text { Excavated Opening } \\
\text { - Waste Package } \\
\text { - Invert (ballast) } \\
\text { - Waste Form } \\
\text { - Cladding } \\
\end{array}$ & None \\
\hline 2.1.12.07.0A & $\begin{array}{l}\text { Effects of radioactive } \\
\text { gases in EBS }\end{array}$ & $\begin{array}{l}\text { Radioactive gases may exist or be produced in the repository. } \\
\text { These gases may subsequently escape from the repository. } \\
\text { Typical radioactive gases include }{ }^{14} \mathrm{C} \text { (in }{ }^{14} \mathrm{CO}_{2} \text { and }{ }^{14} \mathrm{CH}_{4} \text { produced } \\
\text { during microbial degradation), tritium, fission gases ( } \mathrm{Ar}, \mathrm{Xe}, \mathrm{Kr} \text { ), } \\
\text { and radon. }\end{array}$ & $\begin{array}{l}\text { EBS } \\
\text { WF }\end{array}$ & $\begin{array}{l}\text { - Waste Package } \\
\text { - Waste Form } \\
\text { - Cladding }\end{array}$ & None \\
\hline 2.1.12.08.0A & Gas explosions in EBS & $\begin{array}{l}\text { Explosive gas mixtures could collect in the sealed repository. An } \\
\text { explosion in the repository could have radiological consequences if } \\
\text { the structure of the repository were damaged or near-field } \\
\text { processes enhanced or inhibited. }\end{array}$ & EBS & $\begin{array}{l}\text { - Drip Shield } \\
\text { - Waste Package } \\
\text { - Waste Form } \\
\text { - Cladding }\end{array}$ & None \\
\hline
\end{tabular}


Table 6-2. Sharing Reports and EBS Components Addressed in Each FEP (Continued)

\begin{tabular}{|c|c|c|c|c|c|}
\hline FEP Number ${ }^{a}$ & FEP Name ${ }^{a}$ & FEP Description ${ }^{a}$ & $\begin{array}{c}\text { Sharing } \\
\text { Report(s) }\end{array}$ & $\begin{array}{c}\text { EBS Components } \\
\text { Specifically Addressed } \\
\text { (ITWl as identified } \\
\text { in the Q-List) }\end{array}$ & Comments \\
\hline $2.1 .13 .01 .0 \mathrm{~A}$ & Radiolysis & $\begin{array}{l}\text { Alpha, beta, gamma, and neutron irradiation of water can cause } \\
\text { disassociation of molecules, leading to gas production and changes } \\
\text { in chemical conditions (potential, pH, and concentration of reactive } \\
\text { radicals). }\end{array}$ & $\begin{array}{l}\text { EBS } \\
\text { WF } \\
\text { WP }\end{array}$ & - Waste Package & None \\
\hline 2.1.13.02.0A & Radiation damage in EBS & $\begin{array}{l}\text { Radiolysis due to the alpha, beta, gamma-ray, and neutron } \\
\text { irradiation of water could result in enhancement of the radionuclide } \\
\text { migration from the surface of a degraded waste form into } \\
\text { groundwater. When radionuclides decay, the emitted high-energy } \\
\text { particle could result in the production of radicals in the water or air } \\
\text { surrounding the spent nuclear fuel. If these radicals migrate } \\
\text { (diffuse) to the surface of the fuel, they may then enhance the } \\
\text { degradation/corrosion rate of the fuel (UO2). This effect would } \\
\text { increase the dissolution rate for radionuclides from the fuel material } \\
\text { (fuel matrix) into the groundwater. Strong radiation fields could } \\
\text { lead to radiation damage to the waste forms (CSNF, DSNF, } \\
\text { DHLW), waste packages, drip shield, seals, and surrounding rock. }\end{array}$ & $\begin{array}{l}\text { EBS } \\
\text { WF } \\
\text { WP }\end{array}$ & $\begin{array}{l}\text { - Drip Shield } \\
\text { - Waste Package } \\
\text { - Waste Package } \\
\text { Emplacement Pallet } \\
\text { - Waste Form }\end{array}$ & None \\
\hline 2.1.13.03.0A & $\begin{array}{l}\text { Radiological mutation } \\
\text { of microbes }\end{array}$ & $\begin{array}{l}\text { Radiation fields could cause mutation of microorganisms, leading to } \\
\text { unexpected chemical reactions and impacts. }\end{array}$ & EBS & $\begin{array}{l}\text { - Emplacement Drift } \\
\text { Excavated Opening }\end{array}$ & $\begin{array}{l}\text { FEP addresses the drift } \\
\text { environment. }\end{array}$ \\
\hline $2.2 .01 .02 .0 \mathrm{~A}$ & $\begin{array}{l}\text { Thermally-induced stress } \\
\text { changes in the near-field }\end{array}$ & $\begin{array}{l}\text { Changes in host rock properties may result from thermal effects or } \\
\text { other factors related to emplacement of the waste. Properties that } \\
\text { may be affected include rock strength, fracture spacing and block } \\
\text { size, and hydrologic properties such as permeability and sorption. }\end{array}$ & $\begin{array}{l}\text { EBS } \\
\text { UZ }\end{array}$ & - Emplacement Drift & $\begin{array}{l}\text { FEP relates to the UZ above and } \\
\text { below the repository. }\end{array}$ \\
\hline 2.2.01.02.0B & $\begin{array}{l}\text { Chemical changes in the } \\
\text { near-field from backfill }\end{array}$ & $\begin{array}{l}\text { Changes in host rock properties may result from chemical effects of } \\
\text { backfill. Properties that may be affected include permeability and } \\
\text { sorption. }\end{array}$ & EBS & & $\begin{array}{l}\text { Backfill not in repository design, } \\
\text { individual components not } \\
\text { addressed }\end{array}$ \\
\hline $2.2 .07 .06 .0 \mathrm{~A}$ & $\begin{array}{l}\text { Episodic or pulse release } \\
\text { from repository }\end{array}$ & $\begin{array}{l}\text { Episodic or pulse release of radionuclides from the repository and } \\
\text { radionuclide transport in the UZ may occur both because of } \\
\text { episodic flow into the repository, and because of pulse releases } \\
\text { from failed waste packages. }\end{array}$ & $\begin{array}{l}\text { EBS } \\
\text { UZ }\end{array}$ & $\begin{array}{l}\text { - Drip Shield } \\
\text { - Waste Package } \\
\text { - Waste Form } \\
\text { - Invert }\end{array}$ & None \\
\hline $2.2 .07 .06 .0 \mathrm{~B}$ & $\begin{array}{l}\text { Long-term release of } \\
\text { radionuclides from the } \\
\text { repository }\end{array}$ & $\begin{array}{l}\text { The release of radionuclides from the repository may occur over a } \\
\text { long period of time, as a result of the timing and magnitude of the } \\
\text { waste packages and drip shield failures, waste form degradation, } \\
\text { and radionuclide transport through the invert. }\end{array}$ & $\begin{array}{l}\text { EBS } \\
\text { UZ }\end{array}$ & $\begin{array}{l}\text { - Waste Package } \\
\text { - Invert (ballast) } \\
\text { - Waste Form } \\
\text { - Drip Shield }\end{array}$ & None \\
\hline $2.2 .07 .21 .0 \mathrm{~A}$ & $\begin{array}{l}\text { Drift shadow forms } \\
\text { below repository }\end{array}$ & $\begin{array}{l}\text { Flow in unsaturated rock tends to be diverted by openings such as } \\
\text { waste emplacement drifts due to the effects of capillary forces. } \\
\text { Flow diversion around the drift openings could lead to the } \\
\text { development of a zone of lower flow rates and low saturation } \\
\text { beneath the drift, known as the drift shadow. Radionuclide } \\
\text { transport rates through the unsaturated rock may be dependent on } \\
\text { whether or not radionuclide releases occur from drifts that are } \\
\text { underlain by a drift shadow. }\end{array}$ & EBS & $\begin{array}{l}\text { - Emplacement Drift } \\
\text { Excavated Opening }\end{array}$ & $\begin{array}{l}\text { FEP addresses the drift } \\
\text { environment. FEP relates to the } \\
\text { UZ below the repository. }\end{array}$ \\
\hline
\end{tabular}


Table 6-2. Sharing Reports and EBS Components Addressed in Each FEP (Continued)

\begin{tabular}{|c|c|c|c|c|c|}
\hline FEP Number ${ }^{a}$ & FEP Name ${ }^{a}$ & FEP Description $^{a}$ & $\begin{array}{c}\text { Sharing } \\
\text { Report(s) }^{\mathrm{a}}\end{array}$ & $\begin{array}{c}\text { EBS Components } \\
\text { Specifically Addressed } \\
\text { (ITWI as identified } \\
\text { in the Q-List) }\end{array}$ & Comments \\
\hline $2.2 .08 .04 .0 \mathrm{~A}$ & $\begin{array}{l}\text { Re-dissolution of } \\
\text { precipitates directs more } \\
\text { corrosive fluids to waste } \\
\text { packages }\end{array}$ & $\begin{array}{l}\text { Re-dissolution of precipitates that have plugged pores as a result of } \\
\text { evaporation of groundwater in the dry-out zone, may produce a } \\
\text { pulse of fluid reaching the waste packages when gravity-driven flow } \\
\text { resumes, which is more corrosive than the original fluid in the rock. }\end{array}$ & $\begin{array}{l}\text { EBS } \\
\text { UZ }\end{array}$ & $\begin{array}{l}\text { - Emplacement Drift } \\
\text { Excavated Opening } \\
\text { - Waste Package }\end{array}$ & $\begin{array}{l}\text { FEP addresses the drift } \\
\text { environment. FEP relates to the } \\
\text { UZ above the repository. }\end{array}$ \\
\hline
\end{tabular}

a Source: DTN: MO0501SEPFEPLA.001 [DIRS 172601], file FEPS_be.mab, table "FEPS." Sharing reports are in the column labeled "AMR" in the table "FEPS." Use the arrow keys ("<" and ">") in the "AMR" cell of the table "FEPS" to identify multiple sharing reports. Deviations in two FEP titles and descriptions in DTN: MO0501SEPFEPLA.001 [DIRS 172601] are documented in Technical Management Review Board (TMRB) Decision Proposal. TMRB-2005-047 (BSC 2005 [DIRS 174965]), and Technical Management Review Board (TMRB) Decision Proposal. TMRB-2005-050 (BSC 2005 [DIRS 174990]). (See footnotes b“ and d" below)

b Source: BSC (Bechtel SAIC Company) 2005. Technical Management Review Board (TMRB) Decision Proposal. TMRB-2005-047 [DIRS 174965].

${ }^{c}$ This FEP was added to the WP sharing report, but the shared status is not reflected in the source DTN.

d Source: BSC (Bechtel SAIC Company) 2005. Technical Management Review Board (TMRB) Decision Proposal. TMRB-2005-050 [DIRS 174990].

NOTES: "CLAD" designates the report Clad Degradation - FEPS Screening Arguments (BSC 2004 [DIRS 170019]). "DE" designates the report Features, Events, and Processes: Disruptive Events (BSC 2005 [DIRS 173981]). "EBS" designates the current report.

"WF" designates the report Waste-Form Features, Events, and Processes (BSC 2004 [DIRS 170020]).

"WP" designates the report Screening of Features, Events, and Processes in Drip Shield and Waste Package Degradation (BSC 2005 [DIRS 174995]).

"UZ" designates the report Features, Events, and Processes in UZ Flow and Transport (BSC 2005 [DIRS 174191]). 


\subsubsection{Intended Use and Limitations}

This report is intended to provide FEP screening information for a project-specific FEP database, and to promote traceability and transparency regarding FEP screening. This report is intended to be an input to the FEP database described in The Development of the Total System Performance Assessment-License Application Features, Events, and Processes (BSC 2005 [DIRS 173800], Section 6). For included FEPs, this document summarizes and consolidates the method of implementation of the FEP in TSPA-LA in the form of TSPA disposition statements, based on more detailed implementation information in the listed supporting technical reports. For excluded FEPs, this document provides the technical basis for exclusion in the form of screening arguments.

Inherent in this evaluation approach is the limitation that the repository will be constructed, operated, and closed according to the design used as the basis for the FEP screening and in accordance with NRC license requirements. This is inherent in performance evaluation of any engineering project, and design verification and performance confirmation are required as part of the construction and operation processes. The results of the FEP screening presented herein are specific to the repository design evaluated in this report for TSPA-LA.

Any changes in direct inputs listed in Section 4.1, in baseline conditions used for this evaluation or in other subsurface conditions, will need to be evaluated to determine if the changes are within the limits stated in the FEP evaluations. Engineering and design changes are subject to evaluation to determine if there are any adverse manner impacts to safety as codified at 10 CFR 63.73 and in Subparts F and G [DIRS 173273]. See also the requirements at 10 CFR 63.44 and 10 CFR 63.131 [DIRS 173273].

\subsection{EBS FEPS SCREENING AND ANALYSIS}

The following sections summarize the screening of the 90 EBS FEPs that have been identified for TSPA-LA (Table 1-1).

\subsubsection{Chemical Effects of Excavation and Construction in EBS}

\section{FEP Number:}

1.1.02.00.0A

FEP Description: Chemical effects associated with excavation and construction of the underground regions of the repository may affect the long-term behavior of the engineered and natural barriers. Excavation-related effects include chemical changes to the rock and incoming groundwater due to explosives residue. Excavation and other construction activities could also directly cause groundwater chemistry changes within the tunnel due to contaminants such as diesel exhaust, explosives residues, or other organic contaminants. Finally, oxidizing water introduced into the repository during excavation and construction could impact repository conditions and performance.

\section{Screening Decision:}

Excluded (Low Consequence) 
Screening Argument: Subsurface Facility Description Document (BSC 2005 [DIRS 174514], Section 3.1.1.13.7) dictates that the facility shall be designed to maintain a minimum standoff of $120 \mathrm{~m}$ from the water table. The repository horizon lies well above (approximately $300 \mathrm{~m}$ ) the water table, as documented in D\&E/RIT IED Subsurface Facilities [Sheet 1 of 4] (BSC 2004 [DIRS 172801], Table 2, for repository elevation) and in Development of Numerical Grids for UZ Flow and Transport Modeling (BSC 2004 [DIRS 169855], Figure 6-2, for water table elevation). The emplacement drifts will be configured as a series of tunnels in the mountain. Several excavation methods will be employed, but the primary method will be by tunnel-boring machine. Water introduced into the repository by the tunnel-boring machine is used to control dust (BSC 2005 [DIRS 174514], Section 2.3.2). Some water will also be introduced by the dust control functions of the tunnel-boring machine (BSC 2005 [DIRS 174514], Section 2.3.2). However, any introduced water remaining in the repository is expected to be removed by the repository ventilation system, which will operate during waste emplacement and for a minimum of 50 years after waste emplacement (BSC 2005 [DIRS 174514], Section 4.1.1.3). Dryout of the repository during ventilation is discussed in Multiscale Thermohydrologic Model (BSC 2005 [DIRS 173944], Section 6.1.3).

The excavation/construction and preclosure operations phase of the repository could introduce materials that have potential chemical effects on the repository. These materials could conceivably, if not controlled, have an impact on groundwater chemistry within the EBS, thereby impacting corrosion processes and radionuclide transport. Materials planned to be installed in the repository are summarized in IED Subsurface Facilities Committed Materials [Sheet 1 of 1] (BSC 2005 [DIRS 173871]).

Potential use of explosives to blast through rock materials in the excavation phase could introduce chemical components whose composition depends on the types of explosives used. The excavation and operations period could also introduce other organic and inorganic components from construction materials and fluids such as diesel fuel, lubricants, coolants, battery acid, cleaning solvents, and oil mist from compressed air systems. To preclude this from happening, requirements have been established to control undesirable materials from being left in the repository that could have an adverse impact on postclosure performance, as discussed in Subsurface Facility Description Document (BSC 2005 [DIRS 174514], Section 3.1.1.15.1) and Postclosure Modeling and Analyses Design Parameters (BSC 2004 [DIRS 169885], Table 13). Procedures will be followed to ensure that materials introduced into the repository prior to closure have negligible consequences on repository performance (BSC 2004 [DIRS 169885], Table 13; BSC 2005 [DIRS 174514], Section 3.2.4.10). These controls will be adhered to during the preclosure phase of project operations in accordance with the procedures developed for this phase of the operation. The inspection process described in Postclosure Modeling and Analyses Design Parameters (BSC 2004 [DIRS 169885], Table 13) ensures that chemical impacts from excavation will be evaluated on an ongoing basis, and any conditions that are determined to have a potential impact on the postclosure repository conditions will be identified and addressed.

The potential for chemical changes to the host rock or seepage water is discussed under FEP 2.2.01.01.0B in Features, Events, and Processes in UZ Flow and Transport (BSC 2005 [DIRS 174191], Section 6.9.2). Dust generated as a result of construction activities could result in deliquescence on EBS components. Dust deliquescence is discussed in Sections 6.2.61 and 6.2.62 of the present report (FEPs 2.1.09.28.0A and 2.1.09.28.0B). 
In summary, omission of the chemical effects of excavation and construction from the TSPA-LA will not have a significant effect on the magnitude and time of the resulting radiological exposures to the RMEI or radionuclide releases to the accessible environment.

TSPA Disposition:

N/A

Supporting Documents:

N/A

\subsubsection{Mechanical Effects of Excavation and Construction in EBS}

\section{FEP Number:}

FEP 1.1.02.00.0B

FEP Description: Mechanical effects associated with excavation and construction of the underground regions of the repository may affect the long-term behavior of the engineered and natural barriers. Excavation-related effects include changes to rock properties due to boring and blasting.

\section{Screening Decision:}

Excluded (Low Consequence)

Screening Argument: Mechanical effects of excavation or construction in the EBS are limited to a discussion of increased probability of rockfall due to mechanical damage caused by the tunnel-boring machine. Excavation effects on the near field, including mechanical effects of excavation on fractures in the excavation-disturbed zone, near-field fractures, and seepage are not part of this FEP. They are addressed in Section 6.2.84 of the present report under FEP 2.2.01.02.0A. Effects from blasting are not considered because all areas in which waste packages are to be emplaced will be excavated using a tunnel-boring machine only (i.e., without blasting).

As discussed in Subsurface Facility Description Document (BSC 2005 [DIRS 174514], Section 2.3.2), the emplacement drifts, access mains, and exhaust mains are to be constructed using a tunnel-boring machine. Tunnel-boring machines on the Yucca Mountain Project excavate a circular cross-sectional opening. The tunnel-boring machine uses a series of rolling disc cutters mounted on a rotating face to gradually cut the rock by forming rock chips under the shearing action of the cutters, as described in the study by Craig (2001 [DIRS 171411], pp. 1 and 3). The resulting tunnel cross-section is nominally circular with a relatively smooth surface profile. In areas of strong fracturing, a "plucking" action of the cutters can sometimes remove small blocks from the tunnel periphery, creating a slightly irregular surface roughness, although the cross-section profile remains circular. The tunnel-boring machine provides the least destructive technique for excavation since excessive energy (as in blasting) is not used for breakage of the rock. The result of this excavation method is a circular cross-sectional profile with minimal mechanical damage to the rock mass (Craig 2001 [DIRS 171411], p. 16; BSC 2005 [DIRS 174514], Section 2.3.2). 
The potential effects of excavation on mechanical response of the rock mass fall into two categories: (1) ability to develop nominally circular tunnel profiles consistent with modeling assumptions, and (2) mechanical damage to the rock mass in the periphery of the tunnel that may significantly alter or degrade its mechanical properties. The extensive, existing Exploratory Studies Facility (ESF) and Enhanced Characterization of the Repository Block (ECRB) Cross-Drift tunnels were driven with 7.62-m and 5-m diameter tunnel-boring machines and provide an excellent case history of the ability to excavate and maintain nominally circular cross sections within the repository host rock units. Additionally, examination of the tunnel periphery through surface geologic mapping and borehole logging has been used to define the character and extent of mechanical damage induced by the tunnel-boring machine cutting action (Craig 2001 [DIRS 171411], p. 7).

The mapping and observations in the ESF and ECRB Cross-Drift are described in the study by Craig (2001 [DIRS 171411], p. 7). This study resulted in the following observations for tunnel-boring machine excavations:

- Circular Cross Section-Where the rock mass has relatively few natural fractures, the roughness of the tunnel walls (resulting from the action of the disc cutters) is on the order of 1 to $10 \mathrm{~mm}$. Where the rock is heavily fractured with natural jointing, the tunnel wall surface roughness is controlled by the natural fracturing, resulting in a "washboard" surface appearance. In all cases, the circular cross-section of the tunnel is maintained, and the variability of this cross-section introduced by surface roughness is very small in comparison to the tunnel radius.

- Excavation-Induced Damage to Rock Mass-The tunnel-boring machine-induced fracturing of the tunnel periphery is confined to a depth of influence of only a few centimeters.

This depth of mechanically induced damage is therefore less than $1 \%$ of the tunnel diameter except where natural fractures are abundant and damage effects can penetrate up to $50 \mathrm{~cm}$ (Craig 2001 [DIRS 171411, p. 16). In either case, no significant impacts on rock mass mechanical properties are expected to result from mechanical damage associated with tunnel-boring activities. Additionally, the surface roughness of the resulting excavations is insignificant in comparison to the tunnel diameter, and the assumption, used in modeling studies, of initially circular tunnels is reasonable. Therefore, the mechanical effects of excavation, including the ability to maintain a circular cross section, and the negligible depth of damage, need not be included in mechanical stability modeling studies and are excluded from further analysis.

In summary, omission of the mechanical effects of excavation and construction from the TSPA-LA will not have a significant effect on the magnitude and time of the resulting radiological exposures to the RMEI or radionuclide releases to the accessible environment.

TSPA Disposition:

N/A 


\section{Supporting Documents:}

N/A

\subsubsection{Preclosure Ventilation}

\section{FEP Number:}

$$
\text { 1.1.02.02.0A }
$$

FEP Description: The duration of preclosure ventilation acts together with waste package spacing (as per design) to control the extent of the boiling front (zone of reduced water content).

\section{Screening Decision:}

Included

\section{Screening Argument:}

N/A

TSPA Disposition: Preclosure ventilation FEPs are shared between EBS and UZ. Discussion of the TSPA disposition of this FEP in UZ models is found in Features, Events, and Processes in UZ Flow and Transport (BSC 2005 [DIRS 174191], Section 6.2.1). The following discussion describes disposition of preclosure ventilation in the EBS TSPA-LA models.

Ventilation Model and Analysis Report (BSC 2004 [DIRS 169862]) calculates the preclosure thermal conditions in the host rock and characterizes the preclosure host rock response in terms of ventilation efficiency. The ventilation efficiency is computed as a percentage (greater than $70 \%$ ) of total decay heat that is removed from the repository by the vent air; the method of calculation is shown in Ventilation Model and Analysis Report (BSC 2004 [DIRS 169862], Section 6.4). The ventilation efficiency is determined through simulation of temporally and spatially dependent heat transfer processes (thermal radiation, convection, and conduction), which occur simultaneously in the drift and the surrounding rock mass during the ventilating or preclosure period. The ventilation efficiency is a direct input to the model described in Multiscale Thermohydrologic Model (BSC 2005 [DIRS 173944], Section 8.1), which uses it to reduce the heat generation rate during preclosure ventilation (the heat generation rate is multiplied by a specified fraction). The multiscale thermohydrologic model (MSTHM) in turn provides postclosure thermal and relative humidity conditions to the TSPA-LA (BSC 2005 [DIRS 173944], Section 8.3). Thus, the ventilation model and the MSTHM address the effect of ventilation on the removal of waste package heat during the preclosure period. Sensitivity studies on ventilation with and without water phase change processes and water vapor mass transport in the host rock, drift wall, and ventilation air are documented in Ventilation Model and Analysis Report (BSC 2004 [DIRS 169862], Appendix XIII). The impact of water phase changes is insignificant to preclosure ventilation.

The ventilation model provides direct input to Drift-Scale Coupled Processes (DST and TH Seepage) Models (BSC 2005 [DIRS 172232], Sections 6.2.4.2.1) to enable calculations of seepage into thermally perturbed emplacement drifts. It also provides direct input to Drift Scale THC Seepage Model (BSC 2005 [DIRS 172862], Section 8.2) to enable predictions of water chemistry in the host rock surrounding thermally perturbed emplacement drifts. 


\section{Supporting Documents:}

BSC 2004 [DIRS 169862]

BSC 2005 [DIRS 172862]

BSC 2005 [DIRS 172232]

\subsubsection{Undesirable Materials Left}

\section{FEP Number:}

1.1.02.03.0A

FEP Description: During construction and preclosure operation of the repository, unwanted materials might be left in the vicinity of the radioactive waste. These materials could, to some extent, affect many long-term processes in the repository from waste package corrosion to radionuclide transport mechanisms.

\section{Screening Decision:}

Excluded (Low Consequence)

Screening Argument: The excavation/construction and preclosure operations phase of the repository could introduce materials that have the potential to affect physical, chemical, hydrologic, or other processes in the repository. Such materials would include sample placards, survey targets, tape measures, hand or power tools, silicone grout from sampling and mapping activities, or possibly testing apparatus used before waste packages or drip shields are emplaced. These materials could conceivably, if not controlled, have an impact on in-drift thermal transport or groundwater chemistry within the EBS, thereby impacting temperature fields, localized relative humidity, or corrosion processes and radionuclide transport. Materials planned to be installed in the repository are summarized in IED Subsurface Facilities Committed Materials [Sheet 1 of 1] (BSC 2005 [DIRS 173871]).

To preclude this from happening, requirements have been established to control undesirable materials from being left in the repository that could have an adverse impact on postclosure performance. These requirements are discussed in Subsurface Facility Description Document (BSC 2005 [DIRS 174514], Section 3.1.1.15.1) and Postclosure Modeling and Analyses Design Parameters (BSC 2004 [DIRS 169885], Table 13). These controls will be adhered to during the preclosure phase of operation in accordance with the procedures developed for this phase of the operation. In summary, the quantity of undesirable materials left in the repository will be controlled to acceptable levels such that it will not have a significant effect on repository performance.

Omission of this FEP from TSPA-LA will therefore have low consequences for the magnitude and time of the resulting radiological exposures to the RMEI or radionuclide releases to the accessible environment.

TSPA Disposition:

N/A

\section{Supporting Documents: \\ N/A}




\subsubsection{Error in Waste Emplacement}

FEP Number:

1.1.03.01.0A

FEP Description: Deviations from the design and/or errors in waste emplacement could affect long-term performance of the repository. A specific example of such an error would be erroneously emplacing the waste packages in a saturated or wet zone of the repository. Errors of this type would impact repository performance by affecting waste package corrosion and radionuclide transport.

\section{Screening Decision:}

Excluded (Low Consequence)

Screening Argument: FEP 1.1.03.01.0A, Error in Waste Emplacement, is shared with Screening of Features, Events, and Processes in Drip Shield and Waste Package Degradation (BSC 2005 [DIRS 174995], Section 6.2.1). Waste will be emplaced according to the description in Subsurface Facility Description Document (BSC 2005 [DIRS 174514], Section 4.1.1). The impact of errors in waste package emplacement is expected to be very low because of the administrative and procedural control measures that will be instituted. This applies to emplacement errors such as emplacing a waste package with surface contamination above design limits, waste packages that are improperly placed on the drift floor, or waste packages that are placed too close together.

The consequences of a potential error in drip shield emplacement are discussed as part of FEP 1.1.03.01.0A in Screening of Features, Events, and Processes in Drip Shield and Waste Package Degradation (BSC 2005 [DIRS 174995] Section 6.2.1) and found not to affect repository performance.

Any residual defects or deficiencies, therefore, will be minor and will not lead to significant effects on repository performance. These specifications ensure a low consequence (it is unlikely that there will be significant effects from undetected deviations) in the event that there is an error in waste emplacement.

Thus, the magnitude and time of the resulting radiological exposures to the RMEI or radionuclide releases to the accessible environment would not be significantly changed by the exclusion of this FEP.

TSPA Disposition:

N/A

\section{Supporting Documents:}

N/A 


\subsubsection{Error in Backfill Emplacement}

FEP Number:

1.1.03.01.0B

FEP Description: Deviations from the design and/or errors in the backfill emplacement could affect long-term performance of the repository.

\section{Screening Decision:}

Excluded (Low Probability)

Screening Argument: As discussed in Postclosure Modeling and Analyses Design Parameters (BSC 2004 [DIRS 169885], Table 4), there is no backfill used in the design baseline in the emplacement drifts at Yucca Mountain. Materials planned to be installed in the repository are summarized in IED Subsurface Facilities Committed Materials [Sheet 1 of 1] (BSC 2005 [DIRS 173871]). Thus, it is not credible that this FEP concerning backfill will occur.

However, it is planned that backfill materials will be placed in "nonemplacement openings," mainly in access drifts, ramps, and shafts/raises. This has been proposed as a deterrent to human intrusion, as discussed in Subsurface Facility Description Document (BSC 2005 [DIRS 174514], Section 4.1.1.3.6.3). Magma plugs and their functions are discussed as part of FEP 1.2.04.04.0C in Features, Events, and Processes: Disruptive Events (BSC 2005 [DIRS 173981], Section 6.2.2.3). Keyways, in the crown of access and exhaust mains between each emplacement drift, will be used in conjunction with backfill to prevent volcanic intrusions from affecting more than one emplacement drift (BSC 2005 [DIRS 174514], Section 4.1.1.3.6.3). As this is not relevant to backfill in emplacement drifts, error in backfill emplacement in nonemplacement openings is not discussed here.

TSPA Disposition:

N/A

Supporting Documents:

$\mathrm{N} / \mathrm{A}$

\subsubsection{Fault Displacement Damages EBS Components}

\section{FEP Number:}

1.2.02.03.0A

FEP Description: Movement of a fault that intersects drifts within the repository may cause the EBS components to experience related movement or displacement. Repository performance may be degraded by such occurrences as tilting of components, component-to-component contact, or drip shield separation. Fault displacement could cause a failure as significant as shearing of drip shields and waste packages by virtue of the relative offset across the fault, or as extreme as exhumation of the waste to the surface.

Note: A more detailed technical basis for this shared FEP is presented in Features, Events and Processes: Disruptive Events (BSC 2005 [DIRS 173981], Section 6.2.1.2). 


\section{Screening Decision:}

Included

\section{Screening Argument: N/A}

TSPA Disposition: The potential for fault displacements leading to damage from intrablock faults and features likely to exist within the repository is included in the TSPA-LA. The repository design serves as the basis for the TSPA-LA model of fault damage. A complete discussion of probable fault displacement is found in Features, Events, and Processes: Disruptive Events (BSC 2005 [DIRS 173981], Section 6.2.1.2). Consequences and the manner of inclusion are addressed in Seismic Consequence Abstraction (BSC 2005 [DIRS 173247], Sections 6.7 and 6.9), which presents a full description of the treatment of seismic consequences in TSPA-LA. The discussion is summarized here.

For a fault displacement that occurs along an emplacement drift, a sudden discontinuity in the floor and roof of the tunnel may occur. Such a displacement would result in a vertical displacement of the tunnel relative to the adjacent section. Such a displacement along the tunnel axis could cause separation of adjacent drip shields and, if severe enough, shearing of the drip shield at that location. Fault displacement could therefore impact key EBS components in two ways:

- Separation between adjacent drip shields can allow a pathway for seepage to contact the waste packages, thereby potentially accelerating corrosion-induced waste package failure.

- Fault displacement can directly cause mechanical damage to the waste packages.

Within the emplacement drifts that have a reasonable likelihood of slipping over the 10,000-year regulatory period, the displacements are generally very small because the repository is intentionally sited between the two major regional faults, Solitario Canyon and Ghost Dance (BSC 2005 [DIRS 173247], Section 6.7). With the exception of these faults, which are immediately outside the western and eastern boundaries of the emplacement drifts, a fault displacement of $1 \mathrm{~m}$ to $2 \mathrm{~m}$ requires an annual frequency of occurrence of about $10^{-8}$ per year on the known intrablock faults (BSC 2005 [DIRS 173247], Section 6.7.2.2).

Damage to the waste package from fault displacement is included in the seismic scenario class for TSPA-LA. The expected number of damaged waste packages on the four known faults that lie within the repository footprint is evaluated for a range of annual exceedance frequencies, based on the mean hazard curves for the Sundance fault, Drill Hole Wash fault, Pagany Wash fault, and Sevier Wash fault, on the clearances between various types of waste packages and the drip shield, and on the expected number of waste packages that lie on these four faults (BSC 2005 [DIRS 173247], Section 6.7.5). The likelihood of movement along other generic faulting features that are currently unknown has also been considered. The clearances between the waste packages and drip shield are based on a simple representation for damage to the invert from fault displacement. The approximation is made that the emplacement pallet collapses into the invert on the elevated side of the fault. No credit is taken for the potential increase in 
clearances due to further shifting of the ballast in the invert or due to failure of the steel framework in the invert.

The location of the repository footprint precludes damage from major faults (such as the Solitario Canyon and Ghost Dance faults) because of the design requirement for a standoff between the emplacement drifts and the major faults. A western splay off the Ghost Dance fault intersects the repository in a contingency area. However, this fault is not considered in the TSPA-LA because the emplacement of waste packages in the contingency area is uncertain (BSC 2005 [DIRS 173247], Section 6.7.2.1).

Damage to the waste package is sampled from a uniform distribution with a lower bound of $0 \mathrm{~m}^{2}$ and an upper bound given by the area of the waste package lid (BSC 2005 [DIRS 173247], Section 6.7.5). The uniform distribution is a simple approximation to the upper and lower damage bounds in lieu of detailed structural response calculations. The upper bound is a reasonable estimate for a severely crimped waste package that loses its lid because of cracking in the welds holding the lid in place. The lower bound is a reasonable estimate for a waste package that is minimally damaged, either because fault displacement slightly exceeds the available clearance or because the shear occurs at a location that is far from the waste package lids.

Crimping is viewed as the main damage mechanism for the waste package because the package is a very robust, thick-walled cylinder that will not be damaged by tilting or minor displacements. In addition, the ability of the waste package to move on the pallet makes it unlikely that a large enough bending moment or torsion can be applied to result in failure.

Damage to a drip shield from fault displacement is assumed to be $100 \%$ if it surrounds a damaged waste package or $0 \%$ if it does not. Similarly, cladding in a waste package is assumed to be $100 \%$ perforated if it is in a damaged waste package or undamaged if its waste package is not affected by fault displacement (BSC 2005 [DIRS 173247], Section 6.10).

Further details of the damage abstraction for the EBS components in response to fault displacement are provided in Seismic Consequence Abstraction (BSC 2005 [DIRS 173247], Section 6.7). That report also provides an algorithmic description and definition of output parameters for the fault displacement damage abstraction for the EBS components (BSC 2005 [DIRS 173247], Section 6.9.2, Operations 3 through 11), as well as a summary of the 24 output parameters for TSPA-LA that specifically relate to damage from fault displacement (BSC 2005 [DIRS 173247], Table 6.9-1).

Floor buckling damage to pallet and invert for the nominal case is discussed in Section 6.2.32 of the present report (FEP 2.1.07.06.0A).

The effects of fault displacement included in TSPA-LA do not consider exhumation of the waste to the surface. The cumulative fault displacement rate of 0.001 to $0.05 \mathrm{~mm} / \mathrm{yr}$ reported in Characterize Framework for Seismicity and Structural Deformation at Yucca Mountain, Nevada (BSC 2004 [DIRS 168030], Table 6) is not significant enough to cause the movement of waste to the surface, which is above the repository by $200 \mathrm{~m}$ or more. 


\section{Supporting Documents:}

BSC 2004 [DIRS 168030]

BSC 2005 [DIRS 173247]

\subsubsection{Seismic Ground Motion Damages EBS Components}

\section{FEP Number:}

1.2.03.02.0A

FEP Description: Seismic activity that causes repeated vibration of the EBS components (drip shield, waste package, pallet, and invert) could result in severe disruption of the drip shields and waste packages, through vibration damage or through contact between EBS components. Such damage mechanisms could lead to degraded performance.

\section{Screening Decision:}

Included

TSPA Disposition: Seismic Consequence Abstraction (BSC 2005 [DIRS 173247]) presents a full description of the treatment of seismic consequences in TSPA-LA. Damage to the waste package and the cladding is included in the seismic scenario class for TSPA-LA. Structural response calculations for the waste package are the basis for predicting damaged areas in response to seismic-induced ground motions. ${ }^{1}$ A more detailed technical basis for this shared FEP is presented in Features, Events and Processes: Disruptive Events (BSC 2005 [DIRS 173981], Section 6.2.1.3). Analyses summarized in this report (FEPs 1.2.03.02.0B and 2.1.06.05.0A in Sections 6.2.9 and 6.2.21, respectively) show that seismic-induced ground motion damage to the drip shield, pallet, and invert is not significant.

The criterion for failure of the waste package outer barrier is based on a residual stress threshold of between 80 and $90 \%$ of the yield strength for Alloy 22, which incorporates a safety factor of 2.2 on the residual stress threshold for failure because of the long lifetime of the waste package (BSC 2005 [DIRS 173247], Section 6.3.2). The criterion for failure of the drip shield plate is based on a residual stress threshold of $50 \%$ of the yield strength of Titanium Grade 7 , which incorporates a safety factor of 2.2 on the residual stress threshold for failure because of the long lifetime of the drip shield (BSC 2005 [DIRS 173247], Section 6.3.3). The residual stress thresholds are based on an analysis of experimental data for stress corrosion cracking, as described in Stress Corrosion Cracking of the Drip Shield, the Waste Package Outer Barrier, and the Stainless Steel Structural Material (BSC 2004 [DIRS 172203]), Section 6.2.1).

This analysis is summarized and extended in Seismic Consequence Abstraction (BSC 2005 [DIRS 173247], Section 6.3), which provides a discussion of stress corrosion cracking of the waste package in Sections 6.3.4 and 6.3.5, and discusses stress corrosion cracking of the drip

\footnotetext{
${ }^{1}$ A vibratory ground motion defines the three-dimensional motion of the earth during a seismic event. Each ground motion defines the displacement, velocity, and acceleration in three component directions as a function of time at a specific repository location. The term "vibratory" refers to the shaking of the earth in response to a seismic event, and does not imply that the amplitudes of the velocity and acceleration components are small.
} 
shield in Section 6.3.6. Damaged areas occur in response to impact of the waste package on the emplacement pallet and to end-to-end impacts of adjacent waste packages. The damaged areas on the waste package are abstracted as a function of peak ground velocity (PGV). To determine the functional dependence on PGV, vibratory ground motions are defined at the emplacement drifts for PGV levels corresponding to annual exceedance frequencies of $10^{-4}, 10^{-5}, 10^{-6}$, and $10^{-7}$, as discussed in Peak Ground Velocities for Seismic Events at Yucca Mountain, Nevada (BSC 2005 [DIRS 170137], Section 6.8 and Appendix C). Multiple sets of three-component ground motions are sampled to capture the variability in the temporal details of the ground motions at the $10^{-5}$ per year $(1.05 \mathrm{~m} / \mathrm{s}), 10^{-6}$ per year $(2.44 \mathrm{~m} / \mathrm{s})$ and $10^{-7}$ per year $(5.35 \mathrm{~m} / \mathrm{s})$ PGV levels (BSC 2005 [DIRS 173247], Section 6.5.1.1). Seismic Consequence Abstraction (BSC 2005 [DIRS 173247], Sections 6.5.1 to 6.5.3) defines the damage abstraction for the waste package in response to vibratory ground motion. An algorithmic description of the damage abstraction, including definitions of the output parameters for the waste package damage abstraction for TSPA, are provided in that report (BSC 2005 [DIRS 173247], Section 6.9.2 and Table 6.9-1).

The structural response calculations do not represent the dynamic response of the invert to ground motion described in Seismic Consequence Abstraction (BSC 2005 [DIRS 173247], Section 6.5.2). The invert is represented as an elastic body whose surface responds instantaneously and uniformly to the given ground motion. The ground motion time histories for the three components of motion are applied directly to the surface of the invert (BSC 2005 [DIRS 173247], Section 6.5.2). This treatment of the invert results in all of the energy from seismic events being transferred directly to the drip shield and emplacement pallet, which represents a conservative approach with respect to damage to the drip shield, pallet, and waste package. The drip shield and invert move synchronously with the free field ground motion, which corresponds to a drip shield that is pinned to the invert by rockfall from a collapsed drift (BSC 2005 [DIRS 173247], Section 6.5.4.1).

Damage to the cladding is also included in the seismic scenario class for TSPA-LA. Structural response calculations for end-to-end impacts of adjacent waste packages define the axial loads on fuel assemblies. These loads are compared to fuel rod failure criteria based on axial buckling for various fuel assembly designs. Comparison of axial loads with the failure criteria indicates that most if not all fuel assemblies will fail under vibratory ground motions at the $2.44 \mathrm{~m} / \mathrm{s}$ and $5.35 \mathrm{~m} / \mathrm{s}$ PGV levels (BSC 2005 [DIRS 173247], Section 6.5.6.2). Cladding will not fail from the vibratory ground motion at the $0.19 \mathrm{~m} / \mathrm{s}$ and $0.384 \mathrm{~m} / \mathrm{s}$ PGV levels because there is no significant movement of the waste package for these ground motions. An algorithmic description of the cladding damage abstraction, including definitions of the output parameters, is provided in Seismic Consequence Abstraction (BSC 2005 [DIRS 173247], Section 6.9.2 and Table 6.9-1).

Ground support damage is discussed in Section 6.2.19 of this report (FEP 2.1.06.02.0A). Drip shield contacts with waste packages are discussed in Seismic Consequence Abstraction (BSC 2005 [DIRS 173247], Sections 6.6.1.2 and 6.7.1). Section 6.2.9 of the present report (FEP 1.2.03.02.0B) discusses analyses that provide drip shield deformation from impact of large rock blocks and clearances between waste packages and the drip shield before and after seismic-induced rockfall. 
The mechanical response of the drip shield to vibratory ground motions has the potential to damage the drip shield as a barrier to flow, as evaluated in Appendix C of this report. This loss of integrity could occur because of damaged areas on the drip shield (i.e., those areas that exceed the residual stress threshold for Titanium Grade 7) caused by impacts between the drip shield and the waste package, emplacement pallet, invert, and drift wall. Loss of integrity as a barrier to flow could also occur because of separation between two adjacent drip shields. Separation is an important consideration because it neutralizes the drip shield as a flow barrier and rockfall barrier. Damage to the drip shield is discussed further in FEPs 1.2.03.02.0B, Seismic-Induced Rockfall Damages EBS Components (Section 6.2.9 of the current report), and 1.2.03.02.0C, Seismic-Induced Drift Collapse Damages EBS Components (Section 6.2.10 of the current report). The potential for seepage to penetrate cracks resulting from seismic-caused damage is discussed in FEP 2.1.03.10.0B, Advection of Liquids and Solids through Cracks in the Drip Shield (Section 6.2.64 of the current report).

Based on the above considerations, damage abstractions for the waste package and cladding in response to vibratory ground motion are included in TSPA. Damage to the drip shield from vibratory ground motion is discussed under FEPs 1.2.03.02.0B, 1.2.03.02.0C, and 2.1.03.10.0B, as found in Sections 6.2.9, 6.2.10, and 6.2.64, respectively, of the current report.

\section{Supporting Documents:}

BSC 2005 [DIRS 173981]

BSC 2005 [DIRS 173247]

\subsubsection{Seismic-Induced Rockfall Damages EBS Components}

\section{FEP Number:}

1.2.03.02.0B

FEP Description: Seismic activity could produce jointed-rock motion and/or changes in rock stress leading to enhanced rockfall that could impact drip shields, waste packages, or other EBS components.

\section{Screening Decision:}

Excluded (Low Consequence)

Screening Argument: Damage to EBS components from seismically induced rockfall is analyzed but not abstracted into the seismic scenario class for TSPA-LA. A more detailed technical basis for this shared FEP is presented in Features, Events, and Processes: Disruptive Events (BSC 2005 [DIRS 173981], Section 6.2.1.4).

In the nonlithophysal zones, large rock blocks can be shaken free from the walls and drop onto the drip shield under the influence of gravity. In the lithophysal zones, the host rock is relatively weak and shatters into smaller fragments that have little capacity to damage the drip shield from individual impacts. Seismic Consequence Abstraction (BSC 2005 [DIRS 173247], Section 6.6.1) provides a description of the rockfall calculations and the drip shield structural response calculations for impacts by large rock blocks and by smaller fragments of rubble. Analysis of the response of EBS components to a catastrophic drift collapse that produces a rockfall en masse is discussed under FEP 1.2.03.02.0C (Section 6.2.10 of the present document). 
The potential for drift collapse and its consequences are addressed in two steps. Drift Degradation Analysis (BSC 2004 [DIRS 166107]) addresses the response of the drifts (drift collapse) to both thermal-stress-induced degradation and seismic events; an overview of the calculation method is given in Sections 6.3 and 6.4 of that report. Seismic Consequence Abstraction (BSC 2005 [DIRS 173247]) then provides a means of quantifying the response of various EBS components to this drift collapse. Drift Degradation Analysis (BSC 2004 [DIRS 166107], Section 6.3) develops a nonlithophysal rockfall model using the three-dimensional discontinuum code 3DEC. The nonlithophysal model results define the size, velocity, and frequency of discrete rock blocks that can be shaken loose and fall down during a seismic event.

The damage to the drip shield from the impact of large rock blocks (see Appendix C, Table C-2), as could be dislodged during a seismic event in nonlithophysal stratigraphic units, is not included in TSPA-LA (BSC 2005 [DIRS 173247], Section 6.9.2, Operations 8 and 9). Damaged areas on the drip shield due to rockfall (see Section 6.2.64 and Appendix $\mathrm{C}$ of the current report) are susceptible to accelerated stress corrosion cracking (BSC 2005 [DIRS 173247], Section 6.3.3). However, the quantity of liquid that can advectively flow through the resulting crack network and impinge on the waste package will be insignificant (see Section 6.2.64 of the current report under FEP 2.1.03.10.0B). In this situation, damage to the drip shield from rock blocks is not included in the seismic scenario class for TSPA-LA.

In the lithophysal zones, the rock mass has lower compressive strength due to the presence of closely spaced lithophysal void spaces that permeate the rock mass. The rubble resulting from failure is expected to be characteristically smaller in size due to the presence of these voids, in addition to a ubiquitous, closely spaced fracture network. Fragments have particle sizes on the order of centimeters to decimeters (BSC 2005 [DIRS 173247], Section 6.6.2.1). These individual fragments have little capacity to damage the drip shield, as demonstrated in Seismic Consequence Abstraction (BSC 2005 [DIRS 173247], Section 6.6.1.2 and Table 6.6-2). Damage to the drip shield from falling rock fragments in the lithophysal zone is neglected for TSPA-LA on this basis.

Structural response calculations determine the damaged areas on the drip shield under vibratory ground motions. However, the presence of damaged areas and the associated network of stress corrosion cracks (SCCs) are not considered further in this FEP or in TSPA-LA because the advective flux of liquid through the drip shield is predicted to be negligible (see Section 6.2.64 of the present report under FEP 2.1.03.10.0B). Stress corrosion cracks resulting from seismic-induced rockfall are not expected to penetrate the drip shield, as described in Section 6.2.64. If cracks were to occur, additional factors that will limit the amount of advective water flow through cracks in the drip shield include (1) the small aperture width (narrow opening and tight cracks) and the presence of capillary forces within the SCCs, and (2) the potential for plugging of the cracks due to mineral deposits.

As discussed in Seismic Consequence Abstraction (BSC 2005 [DIRS 173247], Section 6.5.5), drip shield separation is not considered in TSPA. It was determined that analysis of drip shield separation required a technical approach in which a large number of interlocked drip shields could be represented with unrestrained end boundary conditions. To this end, a kinematic study has been performed for multiple drip shields in an emplacement drift. Based on the results from 
a kinematic study of drip shield motion (BSC 2005 [DIRS 173247], Section 6.5.5), drip shield separation is excluded from TSPA because (1) the interconnected drip shields move synchronously in open drifts (i.e., drifts that are unfilled with rockfall rubble) and do not separate in any of the analyzed cases, even assuming strong ground motion (i.e., $1 \times 10^{-7}$ annual exceedance frequency) and small friction coefficients for the drip shield-invert contact; and (2) the frictional forces from small amounts of rubblized rock can restrain the relative motion between adjacent drip shields, thereby preventing separation. Rubblized rock will generally be present during the large amplitude, low probability seismic events that have the potential to cause drip shield separation. For example, ground motions associated with the $2.44 \mathrm{~m} / \mathrm{s}$ or $5.35 \mathrm{~m} / \mathrm{s}$ PGV level seismic events are large enough to partially or completely collapse drifts in the repository. Rockfall occurs within 15 seconds of the arrival of these large amplitude ground motions, as discussed in Drift Degradation Analysis (BSC 2004 [DIRS 166107], Section 6.3.1.6.1).

An analysis of the pallet during seismic events is documented in Structural Calculations of Waste Package Exposed to Vibratory Ground Motion (BSC 2004 [DIRS 167083], Section 6.2.4). This analysis shows that the pallet will deform (bulge) under dynamic loads imposed by the waste package, thus softening the impact to the waste package outer barrier. However, the pallet will continue to fulfill its function of supporting the waste package (BSC 2004 [DIRS 167083], Figure 9).

Damage to the waste package or cladding from rock blocks is also not included in the seismic scenario class for TSPA-LA. The drip shield remains intact during a seismic event for the ground motions evaluated for the TSPA (BSC 2005 [DIRS 173247], Section 6.6.3). In addition, the drip shield will not separate in response to vibratory ground motions (see Section 6.2.8 of the current document under FEP 1.2.03.02.0A, and BSC 2005 [DIRS 173247], Section 6.5.5). In its intact state, the drip shield will deflect blocks away from the waste package without collapsing or contacting the waste package, even for the largest blocks (BSC 2005 [DIRS 173247], Section 6.6.1.2). According to the calculation presented in Drip Shield Structural Response to Rock Fall (BSC 2004 [DIRS 168993], Section 6), LS-DYNA analysis shows that the deflection of the drip shield due to rockfall is not large enough to contact the waste package. The drip shield structural response calculations are based on rock block sizes determined from seismic rockfall analyses. The drip shield will withstand a 14.5-metric ton rockfall without contacting the waste package (BSC 2004 [DIRS 168993], Sections 3.12 and 6). The drip shield will also withstand an 11.5-metric ton rockfall with a higher impact velocity without contacting the waste package (BSC 2004 [DIRS 168993], Sections 3.12 and 6). The maximum displacement from the 11.5-metric ton rockfall event is $25.4 \mathrm{~cm}$ (BSC 2004 [DIRS 168993], Section 6) and the minimum gap between the drip shield and waste package outer barrier is $36.7 \mathrm{~cm}$ (BSC 2004 [DIRS 168489], Figure 1; also refer to FEP 2.1.03.07.0B in BSC 2005 [DIRS 174995], Section 6.2.14). Supplemental drip shield structural calculations consider a 28.3-metric ton block resulting in a maximum permanent drip shield deflection of $12.9 \mathrm{~cm}$ for a corner impact between longitudinal stiffeners, as documented in Drip Shield Structural Response to Rock Fall Supplemental Calculation (BSC 2005 [DIRS 174052], Table 7-6). These structural calculations all support the conclusion that the drip shield provides protection from rockfall for the waste package and cladding, so this damage mechanism is not included in TSPA-LA. 
In summary, the drip shield remains intact as a mechanical barrier against damage from seismic-induced rockfall in the nonlithophysal zones. It follows that omission of rockfall-induced damage to EBS components from the TSPA-LA will not have a significant effect on the magnitude and time of the resulting radiological exposures to the RMEI or radionuclide releases to the accessible environment.

TSPA Disposition:

N/A

Supporting Documents:

$\mathrm{N} / \mathrm{A}$

\subsubsection{Seismic-Induced Drift Collapse Damages EBS Components}

\section{FEP Number:}

1.2.03.02.0C

FEP Description: Seismic activity could produce jointed-rock motion and/or changes in rock stress leading to enhanced drift collapse that could impact drip shields, waste packages, or other EBS components. Possible effects include both dynamic and static loading.

\section{Screening Decision:}

Excluded (Low Consequence)

Screening Argument: Damage to EBS components from the en masse fall of rock due to seismically induced rockfall in the lithophysal zones is analyzed but not abstracted into the seismic scenario class for TSPA-LA. Vibratory ground motion can cause failure of the host rock around the emplacement drifts, but is anticipated to cause insignificant damage to the drip shield, waste package, and cladding. A more detailed technical basis for this shared FEP is presented in Features, Events and Processes: Disruptive Events (BSC 2005 [DIRS 173981], Section 6.2.1.5). The lithophysal rock will fragment into small rock fragments that have little capability to damage the drip shield, either from individual impacts (see discussion for FEP 1.2.03.02.0B in Section 6.2.9 of the current document) or from their static load, as discussed in Seismic Consequence Abstraction (BSC 2005 [DIRS 173247], Sections 6.6.2 and 6.6.2.1). In the nonlithophysal zones, complete drift collapse and the associated en masse fall of rock is not predicted to occur at the PGV levels of interest for the seismic scenario class (BSC 2005 [DIRS 173247], Section 6.8.1; BSC 2004 [DIRS 166107], Section 6.3.1.6.4). Damage to EBS components from drift collapse and the associated en masse fall of rock is not included in TSPA on this basis.

The potential for drift collapse and its consequences are addressed in two steps. Drift Degradation Analysis (BSC 2004 [DIRS 166107]) addresses the response of the drifts (drift collapse) to both thermal-stress induced degradation and seismic events; an overview of the calculation method is given in Sections 6.3 and 6.4 of that report. Seismic Consequence Abstraction (BSC 2005 [DIRS 173247]) then provides a means of quantifying the response of various EBS components to this drift collapse. 
Drift Degradation Analysis (BSC 2004 [DIRS 166107], Section 8.1) develops a lithophysal rockfall model using the two-dimensional discontinuum code UDEC with appropriate boundary conditions. The lithophysal model results showed that postclosure ground motion causes drift collapse. Drift collapse in the lithophysal zones can impose a static load on the drip shield from the weight of the failed rock mass. These loads were evaluated in Structural Stability of a Drip Shield Under Quasi-Static Pressure [DIRS 170791] Section 5.2.2) and it was determined that the drip shield will support the load and maintain structural stability (BSC 2004 [DIRS 170791], Section 6). The drip shield will not collapse or buckle because the safety factor for the drip shield design under static rockfall loads is approximately 3 , based on detailed structural response calculations with discontinuum (nonuniform) rockfall loads (BSC 2005 [DIRS 173247], Section 6.6.2.2). Seismic Consequence Abstraction (BSC 2005 [DIRS 173247], Section 6.6.2) describes the analyses for the lithophysal rock and the structural response of the drip shield in the lithophysal zones of the repository. Structural response on the drip shield under vibratory ground motions (without drift collapse) is discussed under FEP 1.2.03.02.0B, Seismic-Induced Rockfall Damages EBS Components, in Section 6.2.9 of the current report.

In the nonlithophysal zones, complete drift collapse is not observed for ground motion amplitudes at the $5.35 \mathrm{~m} / \mathrm{s}$ PGV level (BSC 2004 [DIRS 166107], Section 6.3.1.6.4). Since the $5.35 \mathrm{~m} / \mathrm{s}$ PGV level is beyond the maximum PGV value of $4.07 \mathrm{~m} / \mathrm{s}$ that is expected at the repository horizon (BSC 2005 [DIRS 173247], Section 6.8.1), complete collapse of drifts with the associated en masse fall of rock is not expected to occur. In this situation, drift collapse in nonlithophysal rock is neglected in the seismic scenario class for TSPA on this basis. The potential for rockfall to damage the drip shield as a barrier to seepage is discussed under FEP 2.1.03.10.0B, Advection of Liquids and Solids Through Cracks in the Drip Shield (Section 6.2.64 of the current document).

In summary, the drip shield remains intact as a barrier under the static load induced by drift collapse in the lithophysal zones of the repository. It follows that omission of seismic induced damage to EBS components in the event of drift collapse from the TSPA-LA will not have a significant effect on the magnitude and time of the resulting radiological exposures to the RMEI or radionuclide releases to the accessible environment.

TSPA Disposition:

N/A

Supporting Documents:

N/A

\subsubsection{Seismic-Induced Drift Collapse Alters In-Drift Thermohydrology}

\section{FEP Number:}

1.2.03.02.0D

FEP Description: Seismic activity could produce jointed-rock motion and/or changes in rock stress leading to enhanced drift collapse and/or rubble infill throughout part or all of the drifts. Drift collapse could impact flow pathways and condensation within the EBS, mechanisms for water contact with EBS components, and thermal properties within the EBS. 


\section{Screening Decision:}

Included

\section{Screening Argument: N/A}

TSPA Disposition: Seismic-induced rockfall and seismic-induced drift collapse can alter the hydrologic and thermal environment in the drifts after the seismic event. A more detailed technical basis for this shared FEP is presented in Features, Events and Processes: Disruptive Events (BSC 2005 [DIRS 173981], Section 6.2.1.6).

The potential changes in the in-drift environment after a seismic event are discussed in Seismic Consequence Abstraction (BSC 2005 [DIRS 173247], Section 6.8) and included in the seismic scenario class for TSPA-LA.

The collapse of drifts from high amplitude ground motion in the lithophysal zones can alter the shape of the original opening and fill it with rubble, potentially changing the hydrologic and thermal environment around EBS components. These changes can affect a variety of processes (BSC 2005 [DIRS 173247], Section 6.8):

- Seepage may increase because an irregular shape reduces the effectiveness of the drift wall as a capillary barrier, and because of a loosening of the fractures around the drift.

- Temperature of the drip shield and waste package may increase relative to an unfilled drift because the rubble provides an insulating blanket on top of the drip shield.

- Localized corrosion may increase because of increased temperature and because of rock and water contact with the drip shield or waste package.

- The dissolution rates of CSNF and HLW glass increase with temperature.

In the nominal scenario class, the ambient seepage rates are determined in TSPA by using a lookup table for undegraded or moderately degraded drifts. Drift degradation in the nominal scenario class can be caused by thermal stress, rock strength degradation, or minor to moderate seismic events, as discussed in Abstraction of Drift Seepage (BSC 2004 [DIRS 169131], Section 6.5.1.5). The lookup table for the nominal scenario class includes an enhancement factor of $20 \%$ for uncertainty in seepage in non-collapsed or moderately degraded cases due to drift degradation from these processes (BSC 2004 [DIRS 169131], Section 6.7.1.2).

A change in seepage is included in the seismic abstractions by modifying the seepage flux after a seismic event in the lithophysal zones, based on results from Abstraction of Drift Seepage (BSC 2004 [DIRS 169131], Section 6.5.1.5). This is attributable to an increased drift size, an altered drift shape, and the capillary strength that exists in the rubble in the drift (BSC 2004 [DIRS 169131], Section 6.4.2.4.2). This change is invoked after a seismic event occurs, provided the PGV amplitude of the ground motion is large enough to collapse the drifts. For TSPA, ground motion amplitudes with PGV greater than $0.384 \mathrm{~m} / \mathrm{s}$, corresponding to exceedance frequencies less than $1 \times 10^{-4}$ per year, are assumed to collapse drifts in the 
lithophysal zones (BSC 2005 [DIRS 173247], Section 6.8.1). For nonlithophysal zones in the seismic scenario, the seepage abstraction follows the nominal scenario discussed above, which includes an enhancement factor for uncertainty in seepage due to moderately degraded drifts (BSC 2005 [DIRS 173247], Section 6.8.1; BSC 2004 [DIRS 169131], Section 6.7.1.2).

In addition to switching to the seepage table for collapsed drifts, a temperature constraint is also applied to the seepage flux after drift collapse in the lithophysal zones. Specifically, the seepage onto the waste package is set to zero for the period of above-boiling temperatures by using a $100^{\circ} \mathrm{C}$ threshold temperature at the waste package surface. Above the boiling point of water, the thin films are expected to evaporate. Due to the lack of a continuous water film, transport cannot take place. The boiling point is nominally $100^{\circ} \mathrm{C}$, but may vary due to the elevation of the repository or to dissolved salts in the water film. This constraint implies that seepage can enter the drift and be diverted through the rubble to the invert beneath the waste package, but cannot contact the waste package surface until the waste package surface temperature drops below $100^{\circ} \mathrm{C}$. This threshold temperature of $100^{\circ} \mathrm{C}$ is also based on a sensitivity study in Multiscale Thermohydrologic Model (BSC 2005 [DIRS 173944], Section 6.3.7.3 and Table 6.3-44) of seepage arrival times at the drip shield crown for a collapsed drift that is filled with rubble. This study considers rubble with high and low values of thermal conductivity, and seepage magnitudes that vary between 10 liters/year per waste package and 1,000 liters/year per waste package. The temperature threshold of $100^{\circ} \mathrm{C}$ is a reasonable upper bound to the ranges of waste package temperature based on the maximum temperature values at the highest seepage levels presented in Multiscale Thermohydrologic Model (BSC 2005 [DIRS 173944], Table 6.3-44), which significantly delay the arrival of seepage at the drip shield crown. A $100^{\circ} \mathrm{C}$ temperature is therefore an appropriate threshold to limit the presence of liquid seepage reaching the drip shield in a rubble-filled drift in the lithophysal zones.

In the nonlithophysal zones, the temperature constraint on seepage is the same as that used for intact drifts, wherein seepage does not enter the emplacement drifts until the drift wall temperature drops below $100^{\circ} \mathrm{C}$. This is appropriate because complete drift collapse is not predicted to occur in nonlithophysal rock for ground motion amplitudes at or below the $5.35 \mathrm{~m} / \mathrm{s}$ PGV level (BSC 2004 [DIRS 166107], Section 6.3.1.6.4). Since the $5.35 \mathrm{~m} / \mathrm{s} \mathrm{PGV} \mathrm{level} \mathrm{is}$ beyond the maximum PGV values expected at the repository (BSC 2005 [DIRS 173247], Section 6.8.1), complete drift collapse does not occur in the nonlithophysal rock and the use of the temperature constraint on seepage for intact drifts is a reasonable approach in the nonlithophysal zones of the repository.

Thus, for both the lithophysal and nonlithophysal zones, if the waste package temperature is above $100^{\circ} \mathrm{C}$, there can be no advective transport of radionuclides from the package. Nor can diffusive transport occur out of the package because water vapor films are expected to evaporate as documented in EBS Radionuclide Transport Abstraction (BSC 2005 [DIRS 173433], Section 5.5).

Condensation is expected to occur in an intact drift (see FEPs 2.1.08.04.0A and 2.1.08.04.0B in Sections 6.2.35 and 6.2.36 of the current document) and locally in a collapsed, rubble-filled drift. However, the presence of rubble is expected to inhibit the long-range axial transport of water vapor along the drift axis. In addition, with complete collapse of a drift, the crown of the degraded opening is always at a temperature below boiling, as explained in Drift-Scale Coupled 
Processes (DST and TH Seepage) Models (BSC 2005 [DIRS 172232], Section 6.2.5), which promotes local condensation and further inhibits axial transport of water vapor along the length of a drift. The presence of rubble on top of the drip shield has a strong insulating effect (BSC 2005 [DIRS 173944], Section 6.3.7.3), which increases the temperature gradient between the waste package and the adjacent drift wall in comparison to an uncollapsed drift. The temperature difference under these conditions can be as high as $100^{\circ} \mathrm{C}$ at waste package peak temperatures, diminishing with radioactive decay (BSC 2005 [DIRS 172232], Figure 6.2.5-3). This steep gradient will drive vapor toward the wall much more intensely than axially along temperature gradients aligned with the drift axis. The relatively large surface area of the cool rubble at the drift wall will rapidly absorb latent heat of vapor and promote local condensation.

The potential for drift collapse and its consequences are addressed in two steps. Drift Degradation Analysis (BSC 2004 [DIRS 166107]) addresses the response of the drifts (drift collapse) to severe seismic events; an overview of the calculation method is given in Sections 6.3 and 6.4 of that report. Seismic Consequence Abstraction (BSC 2005 [DIRS 173247]) then provides a means of quantifying the response of various EBS components to this drift collapse.

The influence of a low-probability collapsed-drift seismic scenario on in-drift thermal-hydrologic conditions is considered in Multiscale Thermohydrologic Model (BSC 2005 [DIRS 173944], Section 6.3.7). Changes to several MSTHM submodels are required to simulate the influence of drift collapse (BSC 2005 [DIRS 173944], Section 6.3.7). This disposition summarizes the details of those changes.

A rubble-filled drift, as would exist in the event of drift collapse, will have material properties that differ from those of an intact emplacement system. Specifically, the thermal conductivity and permeability will derive from the size distribution of collapsed material. These material variations impact the thermohydrologic properties of the drifts. A detailed description of thermohydrologic conditions in collapsed drifts and their impact on thermal seepage is discussed in Abstraction of Drift Seepage (BSC 2004 [DIRS 169131], Section 6.5.3). These alterations have also been incorporated into the MSTHM, and results provided to TSPA.

Boundary conditions for submodels that comprise the MSTHM are altered to simulate conditions as they are predicted to exist after a seismic event that causes drift collapse. The model generates a list of changes to the location-specific temperature and relative humidity provided by the base case (BSC 2005 [DIRS 173944], Section 6.3.1). The collapsed-drift scenario implemented in MSTHM submodels considers a high and low case for the in-drift thermal conductivity, which correspond to a predicted range of thermal conductivity between the drip shield and the expanded drift boundaries (BSC 2005 [DIRS 173944], Section 6.2.10).

The low thermal conductivity case is intended to account for the increased contact resistance that will be present between fragmented rock in the collapsed zone (BSC 2005 [DIRS 173944], Section 6.2.10.3). The high and low thermal conductivity cases are treated equally (i.e., each has a probability of 0.5 ) for those TSPA realizations in which a seismic event results in drift collapse.

The MSTHM provides an implementation of the collapsed drift scenario to TSPA-LA as changes in the temperature and relative humidity relative to base-case results. Specifically, the 
low-probability seismic scenario implements a $\Delta \mathrm{T}$ and $\Delta \mathrm{RH}$ for realizations that include a drift collapse, as described in Seismic Consequence Abstraction (BSC 2005 [DIRS 173247], Section 6.8.2).

Changes in temperature and relative humidity have been estimated for eight different waste package emplacement configurations using high and low values of thermal conductivity for wet and dry rubble in the drifts, as documented in DTN: LL040310323122.044 [DIRS 168769]. These results provide the basis for modifying the temperature of the waste package and the relative humidity on the waste package after a seismic event (BSC 2005 [DIRS 173247], Section 6.8.2). The modified temperatures and relative humidity are applied as necessary to processes affected by the changes to generate TSPA model predictions.

Seismic Consequence Abstraction (BSC 2005 [DIRS 173247], Section 6.8) describes the postseismic changes in the in-drift environment for the seismic scenario class. Steps 12 and 13 in that report (BSC 2005 [DIRS 173247], Section 6.9.2) summarize the methodology for including post seismic event changes in TSPA.

\section{Supporting Documents:}

BSC 2005 [DIRS 173247]

BSC 2004 [DIRS 166107]

BSC 2004 [DIRS 172232]

BSC 2005 [DIRS 173944] (While FEP 1.2.03.02.0D is not explicitly identified in

Table $6.5-1$ of this supporting document, the FEP is addressed in the report.)

\subsubsection{Flow in the Backfill}

FEP Number:

2.1.04.01.0A

FEP Description: Preferential pathways for flow and diffusion may exist within the backfill and may affect long-term performance of the waste packages. Backfill may not preclude hydrological, chemical, and thermal interactions between waste packages within a drift.

\section{Screening Decision:}

Excluded (Low Probability)

Screening Argument: As discussed in Postclosure Modeling and Analyses Design Parameters (BSC 2004 [DIRS 169885]) Table 4), there is no backfill used in the design baseline in the emplacement drifts at Yucca Mountain. Materials planned to be installed in the repository are summarized in IED Subsurface Facilities Committed Materials [Sheet 1 of 1] (BSC 2005 [DIRS 173871]). Thus, it is not credible that this FEP will occur.

\section{TSPA Disposition:}

N/A

\section{Supporting Documents:}

N/A 


\subsubsection{Chemical Properties and Evolution of Backfill}

FEP Number:

2.1.04.02.0A

FEP Description: The chemical properties of the backfill may affect groundwater flow, waste package and drip shield durability, and radionuclide transport in the waste disposal region. Properties of the backfill may change through time, due to processes such as alteration of minerals.

\section{Screening Decision:}

Excluded (Low Probability)

Screening Argument: As discussed in Postclosure Modeling and Analyses Design Parameters (BSC 2004 [DIRS 169885]) Table 4), there is no backfill used in the design baseline in the emplacement drifts at Yucca Mountain. Materials planned to be installed in the repository are summarized in IED Subsurface Facilities Committed Materials [Sheet 1 of 1] (BSC 2005 [DIRS 173871]). Thus, it is not credible that this FEP concerning backfill will occur.

TSPA Disposition:

N/A

\section{Supporting Documents:}

$\mathrm{N} / \mathrm{A}$

\subsubsection{Erosion or Dissolution of Backfill}

\section{FEP Number:}

2.1.04.03.0A

FEP Description: Solid material in backfill may be carried away by flowing groundwater, either by erosion of particulate matter or by dissolution.

\section{Screening Decision:}

Excluded (Low Probability)

Screening Argument: As discussed in Postclosure Modeling and Analyses Design Parameters (BSC 2004 [DIRS 169885]), there is no backfill used in the design baseline in the emplacement drifts at Yucca Mountain. Materials planned to be installed in the repository are summarized in IED Subsurface Facilities Committed Materials [Sheet 1 of 1] (BSC 2005 [DIRS 173871]). Thus, it is not credible that this FEP concerning backfill will occur.

TSPA Disposition:

N/A

\section{Supporting Documents:}

N/A 


\subsubsection{Thermal-Mechanical Effects of Backfill}

FEP Number:

2.1.04.04.0A

FEP Description: Backfill may alter the mechanical evolution of the drift environment by providing resistance to rockfall and drift collapse, by changing the thermal properties of the drift, or by other means. Impacts of the evolution of the properties of the backfill itself should be considered.

\section{Screening Decision:}

Excluded (Low Probability)

Screening Argument: As discussed in Postclosure Modeling and Analyses Design Parameters (BSC 2004 [DIRS 169885]) Table 4), there is no backfill used in the design baseline in the emplacement drifts at Yucca Mountain. Materials planned to be installed in the repository are summarized in IED Subsurface Facilities Committed Materials [Sheet 1 of 1] (BSC 2005 [DIRS 173871]). Thus, it is not credible that this FEP concerning backfill will occur.

TSPA Disposition:

N/A

\section{Supporting Documents:}

$\mathrm{N} / \mathrm{A}$

\subsubsection{Thermal-Mechanical Properties and Evolution of Backfill}

\section{FEP Number:}

2.1.04.05.0A

FEP Description: The physical properties of the backfill may affect groundwater flow, waste package and drip shield durability, and radionuclide transport in the waste disposal region. Properties of the backfill may change through time, due to processes such as silica cementation, thermal effects, and physical compaction.

\section{Screening Decision:}

Excluded (Low Probability)

Screening Argument: As discussed in Postclosure Modeling and Analyses Design Parameters (BSC 2004 [DIRS 169885],) Table 4), there is no backfill used in the design baseline in the emplacement drifts at Yucca Mountain. Materials planned to be installed in the repository are summarized in IED Subsurface Facilities Committed Materials [Sheet 1 of 1] (BSC 2005 [DIRS 173871]). Thus, it is not credible that this FEP concerning backfill will occur.

\section{TSPA Disposition:}

N/A 


\section{Supporting Documents:}

N/A

\subsubsection{Radionuclide Transport in Backfill}

\section{FEP Number:}

2.1.04.09.0A

FEP Description: Radionuclide transport in the drift environment may be affected by the presence of backfill. Transport (i.e., advective and diffusive effects and sorption processes) of both dissolved and colloidal species should be considered.

\section{Screening Decision:}

Excluded (Low Probability)

Screening Argument: As discussed in Postclosure Modeling and Analyses Design Parameters (BSC 2004 [DIRS 169885],) Table 4), there is no backfill used in the design baseline in the emplacement drifts at Yucca Mountain. Materials planned to be installed in the repository are summarized in IED Subsurface Facilities Committed Materials [Sheet 1 of 1] (BSC 2005 [DIRS 173871]). Thus, it is not credible that this FEP concerning backfill will occur.

TSPA Disposition:

N/A

\section{Supporting Documents:}

N/A

\subsubsection{Chemical Effects of Rock Reinforcement and Cementitious Materials in EBS}

\section{FEP Number:}

2.1.06.01.0A

FEP Description: Degradation of ground support material (e.g., cement, rock bolts, wire mesh) used for any purpose in the disposal region may affect long-term performance through both chemical and physical processes. Degradation may occur by physical, chemical, and microbial processes.

\section{Screening Decision:}

Excluded (Low Consequence)

Screening Argument: Excavation effects on chemistry of the near-field are addressed in Features, Events, and Processes in UZ Flow and Transport (BSC 2005 [DIRS 174191], Section 6.9.2). The discussion considers chemical effects in the excavation-disturbed zone and near-field fractures, and excludes this FEP on the basis of low consequence. The discussion presented below focuses on potential impacts that ground control materials, left in the drift postclosure, might have on chemistry of seepage waters in the drifts. As discussed in Subsurface Facility Description Document (BSC 2005 [DIRS 174514], Section 4.1.1.1), ground control 
materials include stainless steel rock bolts, cementitious grouts in the emplacement drift turnouts, and steel mesh.

The effect of stainless steel corrosion (including the degradation rate) on the chemistry of seepage entering the drift is evaluated in Engineered Barrier System: Physical and Chemical Environment (BSC 2005 [DIRS 175083], Section 6.8), in which it is determined that the degradation of the stainless steel is sufficiently low that it will not materially impact predictions of chemistry.

In Evaluation of Potential Impacts of Microbial Activities on Drift Chemistry (BSC 2004 [DIRS 169991], Section 7.1), rock reinforcement materials and other introduced materials are discussed in the context of environmental constraints on in-drift microbial activity as sources of energy and nutrients. These evaluations show that microbial activity has a small impact on drift chemistry. In summary, these three analyses indicate that the effects of ground support material degradation and microbial activity on the chemical environment in the emplacement drifts can be excluded on the basis of low consequence.

Cementitious material (shotcrete) is planned for use as part of the ground support for the turnout intersections of the main access drifts, and for the turnouts and intersections of the exhaust drifts with the emplacement drifts, as shown in IED Subsurface Facilities Committed Materials [Sheet 1 of 1] (BSC 2005 [DIRS 173871]). The incorporation of cementitious materials in the repository has two potential effects on repository performance. The first is the leaching of cementitious materials, particularly the shotcrete supporting the turnout intersections in the main access drifts and the intersections of the exhaust main drifts with the emplacement drifts. This could affect repository performance by modifying hydrologic properties of the surrounding rock and divert the flow of water entering the drifts. The second effect is that an alkaline plume resulting from leaching of the cementitious material could enhance radionuclide transport to the accessible environment, either through the complexation of radionuclides or through the presence of pseudocolloids.

As discussed in IED Subsurface Facilities Committed Materials [Sheet 1 of 1] (BSC 2005 [DIRS 173871], Table 3), no cementitious material will be used in the emplacement drifts. In nonemplacement drifts, all cementitious material (concrete invert and shotcrete used in shafts) will be removed prior to closure except that necessary for ground support (BSC 2005 [DIRS 174514], Section 3.1.1.15.1). The only significant cementitious materials remaining in the repository will be shotcrete supports and grout for rock bolt placement in nonemplacement drifts and turnout intersections. Water is expected to move in a general vertical flow pattern through the waste emplacement horizon relative to the length scale of these drifts, with some flow diversion around the drifts resulting from the capillary barrier effect. This flow pattern is consistent with the drift-scale seepage model having no-flow lateral-boundary conditions, as discussed in Seepage Model for PA Including Drift Collapse (BSC 2004 [DIRS 167652], Section 6.3.1). Although unlikely, leaching of the shotcrete and subsequent carbonation of leachate in surrounding rock could conceivably lead to precipitation of calcite in fractures and pores beneath the turnout intersections, as calculated in DTN: LB0408CMATUZFT.004 [DIRS 171706]. Standoffs from the shotcrete portions of the turnouts and exhaust drift intersections are established, as shown in Repository Subsurface Turnout Drift 1-8 Interface (BSC 2004 [DIRS 167736]), Repository Subsurface Emplacement Drift Panel 2 General 
Arrangement (BSC 2004 [DIRS 171424]), IED Subsurface Facilities Committed Materials [Sheet 1 of 1] (BSC 2005 [DIRS 173871]), and D\&E/RIT IED Subsurface Facilities [Sheet 1 of 4] (BSC 2004 [DIRS 172801]), to keep the shotcrete removed from waste packages in the emplacement drifts. Calculations (DTN: LB0408CMATUZFT.004 [DIRS 171706], sheet LB0408CMATUZFT.004.doc, table "Estimated Depth of Rock Voids Filled with Calcite Due to the Leaching of Portlandite from Shotcrete in a Main Access Drift Turnout Intersection") show that calcite precipitation will not lead to changes sufficiently large in the local hydrologic properties to divert the dominantly vertical flow beneath the turnouts towards the emplacement drifts.

Details regarding the impact of an alkaline plume are considered as part of FEP 2.2.08.03.0B in Features, Events, and Processes in UZ Flow and Transport (BSC 2005 [DIRS 174191], Section 6.9.7). Several factors, including direct carbonation of the cement itself due to $\mathrm{CO}_{2}$ gas diffusion and carbonation of any hyperalkaline plume that is generated as a result of cement-water interaction, act to minimize the effect of cementitious leachates. Direct carbonation of the cement consumes portlandite and other high-pH phases, rendering it benign. Diffusion of $\mathrm{CO}_{2}$ gas into the hyperalkaline plume, if generated, reduces the $\mathrm{pH}$ and calcium concentration in solution through acidification and calcite precipitation. These processes will result in leachate from the cementitious materials and their reaction products being similar in water quality to ambient porewater (BSC 2005 [DIRS 174191], Section 6.9.7).

In summary, the magnitude and time of the resulting radiological exposures to the RMEI or radionuclide releases to the accessible environment would not be significantly changed by the exclusion of this FEP.

TSPA Disposition:

N/A

Supporting Documents:

N/A

\subsubsection{Mechanical Effects of Rock Reinforcement Materials in EBS}

\section{FEP Number:}

2.1.06.02.0A

FEP Description: Degradation of rock bolts, wire mesh, and other materials used in ground control may affect the long-term performance of the repository.

\section{Screening Decision:}

Excluded (Low Consequence)

Screening Argument: Prior to their degradation, ground control materials would serve to mitigate the potential for rockfall into the drift tunnel. However, the analysis presented in Drift Degradation Analysis (BSC 2004 [DIRS 166107]), which estimates the magnitude of such rockfall, does not take any credit for the existence of rock reinforcement materials, which would mitigate the effects of rockfall. Rock reinforcement materials will degrade and eventually fail during the postclosure period (BSC 2004 [DIRS 166107], Section 6). Not including the presence 
of these materials in the postclosure drift degradation analysis is therefore a reasonable and bounding approach for the analysis. Not including them in the preclosure analysis produces a conservative estimate of drift degradation for the preclosure period. That is, not including rock reinforcement materials in the rockfall models results in an increase in drift degradation. The damage that may be directly caused by degradation of the ground support system, such as a falling rock bolt or portion of the ground support screen, is not significant relative to the impact caused by rockfall. The conservative analyses of drift degradation, which effectively consider complete degradation of rock reinforcement materials, result in minor drift damage due to seismic, thermal, and time-dependent effects during the preclosure period (BSC 2004 [DIRS 166107], Section 8.1). The impact of rockfall occurring during the postclosure period (when complete degradation of rock reinforcement materials is assumed) is addressed in other rockfall and drift collapse FEPs (see Sections 6.2.9, 6.2.10, 6.2.28, and 6.2.29 of the current document).

As discussed in Section 6.2.20 of the current report under FEP 2.1.06.04.0A, the presence of rock bolts has minimal effect on seepage into the repository.

This FEP does not address the chemical effects that degradation of rock bolts or other ground support materials may have on repository performance. These are addressed in Section 6.2.18 of this report under FEP 2.1.06.01.0A.

Thus, omission of the mechanical effects of rock reinforcement materials from the TSPA-LA will not have a significant effect on the magnitude and time of the resulting radiological exposures to the RMEI or radionuclide releases to the accessible environment.

TSPA Disposition:

N/A

Supporting Documents:

N/A

\subsubsection{Flow Through Rock Reinforcement Materials in EBS}

\section{FEP Number:}

2.1.06.04.0A

FEP Description: Groundwater flow may occur through the ground support materials (e.g., wire mesh, rock bolts, grout) and liner (if present).

\section{Screening Decision:}

Excluded (Low Consequence)

Screening Argument: Groundwater flow is modeled in TSPA-LA as being completely unhindered by any rock reinforcement materials. Abstraction of Drift Seepage (BSC 2004 [DIRS 169131], Sections 6.4.2.5 and 6.5.1.6) presents an analysis of the impact of rock bolts on seepage. Section 6.4.2.5 of that report (BSC 2004 [DIRS 169131]) describes a refined seepage model that was developed to evaluate the potential impact of rock bolt ground support on seepage. The results of the study are that no seepage enhancement was obtained due to the 
presence of rock bolts. This result is understandable, considering that the borehole acts as a capillary barrier to flow in the fractured rock, which is similar to the barrier that exists at the rock-drift interface.

Flow through ground support wire mesh is ignored in TSPA-LA. As discussed in Drift Degradation Analysis (BSC 2004 [DIRS 166107], Sections 6 and 6.4.2.1), the ground control system is expected to degrade following repository closure. Neglecting the presence of wire mesh is a realistic representation of the system with respect to groundwater flow. Grout is not a part of the ground support system in the repository drifts.

Therefore, flow through rock reinforcement materials is excluded from TSPA-LA on the basis of low consequence, as the magnitude and time of the resulting radiological exposures to the RMEI or radionuclide releases to the accessible environment would not be significantly changed by the exclusion of this FEP.

TSPA Disposition:

N/A

Supporting Documents:

N/A

\subsubsection{Mechanical Degradation of Emplacement Pallet}

\section{FEP Number:}

2.1.06.05.0A

FEP Description: Degradation of the materials used in the pallet supporting the waste package may occur by physical processes, and may affect the long-term performance of the repository. Degradation may be fast (e.g., from dynamic loading) or slow (e.g., from static loading).

\section{Screening Decision:}

Excluded (Low Consequence)

Screening Argument: Pallet degradation must be considered with respect to its design requirements as described in Postclosure Modeling and Analyses Design Parameters (BSC 2004 [DIRS 169885], Table 8). As noted in that document, the emplacement pallet is required to prevent contact between the waste packages and non-Alloy 22 drift components, such as the invert. Analysis of this design requirement is summarized in Drip Shield and Waste Package Emplacement Pallet Design Report (BSC 2004 [DIRS 166879]). The analysis described in that report shows that the pallet is conservatively designed with margins accounting for corrosion such that it meets the requirement to support the waste package throughout the regulatory period. The pallet design addressed the performance requirement during the preclosure period to retain its form sufficiently to allow lifting of the waste package after exposure to applicable normal condition loads (BSC 2004 [DIRS 166879], Section 7.1.1). During the postclosure period for normal condition loads, pallet design was evaluated using a reduction in plate thickness to include the effects of corrosion during the regulatory period, and found to perform satisfactorily (i.e., the waste package remains on the emplacement pallet) under seismic events with an annual frequency of occurrence of $1 \times 10^{-6}$ per year (BSC 2004 [DIRS 166879], Section 7.2.2). An 
additional assessment of the performance of the emplacement pallet tubes during seismic events with an annual frequency of occurrence of $1 \times 10^{-7}$ per year (with a PGV of $5.35 \mathrm{~m} / \mathrm{s}$ ) indicates that they will perform their function during the regulatory period (BSC 2005 [DIRS 173172], Attachment XI).

An analysis of the pallet during seismic events is documented in Structural Calculations of Waste Package Exposed to Vibratory Ground Motion (BSC 2004 [DIRS 167083], Section 6.2.4). This analysis shows that the pallet will deform (bulge) under dynamic loads imposed by the waste package, thus softening the impact to the waste package outer barrier. However, the pallet will continue to fulfill its function of supporting the waste package (BSC 2004 [DIRS 167083], Figure 9).

Any mechanical degradation of the emplacement pallet will be sufficiently minor such that this FEP can be excluded on the basis of low consequence. Emplacement pallet and other EBS component responses to the seismic events are found in Section 6.2.8 of the present report as part of FEP 1.2.03.02.0A.

In summary, omission of mechanical degradation of the pallet from the TSPA-LA will not have a significant effect on the magnitude and time of the resulting radiological exposures to the RMEI or radionuclide releases to the accessible environment.

TSPA Disposition:

$\mathrm{N} / \mathrm{A}$

Supporting Documents:

$\mathrm{N} / \mathrm{A}$

\subsubsection{Mechanical Degradation of Invert}

\section{FEP Number:}

2.1.06.05.0B

FEP Description: Degradation of the materials used in the invert may occur by physical processes, and may affect the long-term performance of the repository. Degradation may be fast (e.g., from dynamic loading) or slow (e.g., from static loading).

\section{Screening Decision:}

Excluded (Low Consequence)

Screening Argument: The invert provides a structural foundation for the orientation of other EBS components, namely the pallet, waste package, and drip shield. Subsurface Facility Description Document (BSC 2005 [DIRS 174514], Section 3.1.1.10.13) lists invert support requirements and other functional requirements for the invert design to include the following: 1) resistance to construction loads, waste package emplacement pallet and waste package loads, drip shield loads, thermal loads, and seismic loads; 2) appropriate worst-case combinations of in-place, thermal, seismic and operational loads; 3) support to the operational loads from the waste package emplacement gantry, remote inspection gantry, and the drip shield placement equipment gantry crane; 4) support to the operational loads from the backfill emplacement 
equipment, if backfill is used in the design (backfill will not be used); and 5) fabrication from materials that will undergo minimal corrosion during the preclosure period. Degradation, bearing capacity, and long-term settlement properties are also part of the design (BSC 2004 [DIRS 168138], Sections 7.9, 7.10 and 7.11). The degradation property is based on a standard for basalt, which is of volcanic origin and has properties comparable to tuff. The suitability of the Yucca Mountain tuff to have this property is demonstrated by a comparison of test results to performance standards (BSC 2004 [DIRS 168138], Section 7.9). The invert properties have been evaluated and recommendations are provided to ensure the invert will meet these properties (BSC 2004 [DIRS 168138] Section 8).

Loads can result from thermal expansion of the base plates, drip shield, or invert steel structure; rock movement due to in situ stress release from excavation; and rock deformation of the invert. Thermal-mechanical effects on emplacement drift stability and ground support performance have been analyzed in Evaluation of Emplacement Drift Stability for KTI Resolutions (BSC 2004 [DIRS 168889]). The potential for floor buckling is also evaluated as part of FEP 2.1.007.06.0A in Section 6.2.32 of the current report. These analyses, conducted for the preclosure period, show no adverse impacts to performance result from thermal loads. These same loads will be present during postclosure under nominal conditions. The vertical displacement of the floor due to in situ stress and thermal response will be less than $1 \mathrm{~mm}$ per $6 \mathrm{~m}$ of drift (BSC 2004 [DIRS 168889], Table 6.4-3). As noted in D\&E / PA/C IED Emplacement Drift Configuration and Environment (BSC 2004 [DIRS 168489], Figure 1), the engineered clearances between EBS components greatly exceeds this value. Thus, any compaction will be of no consequence to performance of the EBS. To account for added loads during seismic events, Estimation of Mechanical Properties of Crushed Tuff for Use as Ballast Material in Emplacement Drift (BSC 2004 [DIRS 168138], Section 7.10.2) uses an additional factor of $0.17 \mathrm{~g}$ to accommodate the expected loads. A description of the response of the invert to seismic activity as it relates to damaging other EBS components is presented under FEP 1.2.03.02.0A in Section 6.2.8 of the current report.

Invert postclosure performance requirements are assured as discussed below. As explained in Postclosure Modeling and Analyses Design Parameters (BSC 2004 [DIRS 169885], Section 6.7.2), the invert limits radionuclide release rates through the granular invert material by limiting accumulation of water in the invert regime. The invert is composed of mild carbon steel components and crushed tuff, as described in Repository Subsurface Emplacement Drifts Steel Invert Structure Section \& Combined Materials (BSC 2004 [DIRS 169776]). In addition, the hydrologic properties of the invert are considered within models of the in-drift thermohydrologic environment in Multiscale Thermohydrologic Model (BSC 2005 [DIRS 173944], Section 6.3.11), while radionuclide transport from the waste packages to the UZ is analyzed in EBS Radionuclide Transport Abstraction (BSC 2005 [DIRS 173433]). This screening argument considers these aspects of the invert as follows.

The effects of uncertainties in hydrologic properties of the invert have been evaluated in Multiscale Thermohydrologic Model (BSC 2005 [DIRS 173944], Section 6.3.11). Temperature, liquid-phase saturation, and relative humidity are all insensitive to the hydrologic properties of the intergranular porosity. These evaluations show that these uncertainties result in negligible changes to model predictions. 
Consolidation of the crushed tuff could cause a slight reduction in invert porosity. The effects of variable porosity are included in calculating the invert diffusion coefficient described in EBS Radionuclide Transport Abstraction (BSC 2005 [DIRS 173433], Section 6.3.4.1). The diffusion coefficient is calculated to vary by a factor of approximately two over the anticipated porosity range of 0.27 to 0.39 (BSC 2005 [DIRS 173433], Equation 6.3.4.1.1-23). Porosity is only one of several sources of uncertainty in calculation of the diffusion coefficient. Thus, a slight reduction in invert porosity due to consolidation will not affect significantly the diffusion coefficient calculation and will result in negligible changes to radionuclide transport.

Based on these arguments, physical degradation of the invert and invert materials is excluded from the TSPA because the magnitude and time of the resulting radiological exposures to the RMEI or radionuclide releases to the accessible environment would not be significantly changed by its exclusion.

Invert damage due to floor buckling is discussed in Section 6.2.32 of the present report under FEP 2.1.07.06.0A. Invert damage due to drift collapse is discussed in Section 6.2.29 under FEP 2.1.07.02.0A.

TSPA Disposition:

$\mathrm{N} / \mathrm{A}$

Supporting Documents:

N/A

\subsubsection{Chemical Degradation of Emplacement Pallet}

\section{FEP Number:}

2.1.06.05.0C

FEP Description: Degradation of the materials used in the pallet supporting the waste package may occur by chemical or microbial processes, and may affect the long-term performance of the repository.

\section{Screening Decision:}

Excluded (Low Consequence)

Screening Argument: Drip Shield and Waste Package Emplacement Pallet Design Report (BSC 2004 [DIRS 166879]) provides the design methodology for these EBS components. The waste package emplacement pallet supports the waste package during handling, emplacement, preclosure, and postclosure periods, and is fabricated from stainless steel and Alloy 22, as also discussed in IED Subsurface Facilities Committed Materials [Sheet 1 of 1] (BSC 2005 [DIRS 173871]). The pallet is conservatively designed with margins accounting for corrosion such that it meets the requirements to support the waste package (BSC 2004 [DIRS 166879], Section 7.2.2). Stainless steel tubes connect Alloy 22 to waste package supports to form an emplacement pallet. As described in D\&E / PA/C IED Emplacement Drift Configuration and Environment (BSC 2004 [DIRS 168489], Figure 1), the invert consists of a steel structure, gantry rails, and crushed tuff ballast materials. 
The effects of corrosion of carbon steel components on the chemistry of seepage entering the drift is evaluated in Section 6.2.24 of the present report as part of FEP 2.1.06.05.0D. As discussed in Engineered Barrier System: Physical and Chemical Environment (BSC 2005 [DIRS 175083], Section 6.4.1 and accompanying tables), the corrosion rate for Alloy 22 is much slower than that of carbon steel and is not included in model calculations. High early temperatures, the primarily oxic environment, and a relative scarcity of water and organic carbon will combine to limit microbial activity in the emplacement drifts, as discussed in Evaluation of Potential Impacts of Microbial Activities on Drift Chemistry (BSC 2004 [DIRS 169991], Section 6.4). Microbial activity is therefore of low consequence with respect to potential for degradation of the emplacement pallet.

The stainless steel connector tubes, which hold the pallet cradles in position, are an integral part of the waste package emplacement pallet, which is classified as both important to safety and important to waste isolation, as presented in Q-List (BSC 2005 [DIRS 174269], Appendix A). In the postclosure timeframe, the pallet keeps the waste package off of the invert and supports the waste package during a seismic event. While the corrosion of the tubes over the regulatory period is expected to be low enough that the stainless steel tubes retain their structural integrity, the integrity of the tubes is only important in the case of a seismic event of sufficient acceleration to cause the waste package to separate from the pallet. The cradles are the main load-bearing members because the geometry of the pallet and cradles prevents direct impact between the package and the tubes, as discussed in Subsurface Facility Description Document (BSC 2005 [DIRS 174514], Figure 4-7).

Calculations have been performed that demonstrate the durability of the pallet connector tubes in Mechanical Assessment of the Waste Package Subject to Vibratory Motion (BSC 2005 [DIRS 173172], Section XI). This study assumes a thinning of the connector tubes from their original dimensions by $2.1 \mathrm{~mm}$ due to corrosion (BSC 2005 [DIRS 173172], Section XI-2.3), a value that exceeds the corrosion estimate below of $1.5 \mathrm{~mm}$ to occur in the regulatory time frame. Three-dimensional analysis of seven waste packages subjected to vibratory ground motion was performed to understand the kinematics of pallet and waste package components during a seismic event. The results show that the emplacement pallet stainless steel tubes will perform their intended function throughout the regulatory period. This is due to the limited ability for the waste package to make contact with the emplacement pallet tubes, non-rigid boundary conditions, and redundancy in the number of longitudinal tubes (BSC 2005 [DIRS 173172], Section XI-4).

When the drip shield is intact, seepage water is prevented from contacting the connector tubes. The potential for concentrated solutions formed as a result of dust deliquescence to materially influence corrosion have been screened out for Alloy 22, as discussed under FEP 2.1.09.28.0A in Section 6.2.61 of the current report. Most of these same arguments (small brine volume, the sublimation of salts, acid degassing, capillarity of dust deposits, consumption of brines by corrosion products) will directly apply to the stainless steel tubes as well, and thus the tubes will not be susceptible to localized corrosion. Nor will they be susceptible to significant amounts of general corrosion induced by concentrated-salt solutions. For aqueous phase corrosion, long-term fresh-water corrosion rates as described in Aqueous Corrosion Rates for Waste Package Materials (BSC 2004 [DIRS 169982], Table 4-3) are considered the most applicable for this environment since the bulk water will come from condensation and the chemistry will be 
dilute. Aqueous phase corrosion rates in $\mathrm{J}-13$ water at temperatures of $50^{\circ} \mathrm{C}, 80^{\circ} \mathrm{C}$, and $100^{\circ} \mathrm{C}$, in samples exposed for longer than one year, have been measured to be $0.154 \mu \mathrm{m} / \mathrm{year}$, $0.109 \mu \mathrm{m} /$ year, and $0.037 \mu \mathrm{m} /$ year, respectively (BSC 2004 [DIRS 169982] Table 4-3). These data are taken from an article about corrosion of alloy materials (McCright et al. 1987 [DIRS 159336], Table 6) and are qualified as appropriate for intended use (BSC 2004 [DIRS 169982], Section III-38). Studies have shown that there is a continual decrease of the degradation rate of stainless steel over time (Gdowski and Bullen 1988 [DIRS 100860], Figure 19; Larrabee 1953 [DIRS 159337], pp. 259 to 271; Southwell et al. 1976 [DIRS 100927], Table 4), and therefore the values of corrosion rate resulting from these short-term corrosion tests (1.2 to 1.3 years) are higher than the corrosion rates expected when averaged over the design life of the pallet. The highest 316 stainless steel corrosion rate used in In-Package Chemistry Abstraction, $14.8 \mu \mathrm{m} /$ year (BSC 2005 [DIRS 174583], Table 4-8), is higher than the rate used in the current analysis. However, the higher rate, derived from salt-water conditions, is a bounding rate applicable only in a seepage scenario when the drip shield is no longer intact.

Vapor phase corrosion rates for Stainless Steel Type 316L have been compiled and found to have a mean of $0.113 \mu \mathrm{m} /$ year for atmospheric conditions (DTN: MO0407SPAPCEML.005 [DIRS 172097], atmospheric.xls, worksheet "316"). Using the vapor phase corrosion rate for the first 2,000 years during the hot, dry period, and using the aqueous phase corrosion rate of $0.154 \mu \mathrm{m} /$ year at $50^{\circ} \mathrm{C}$ for the remaining 8,000 years, the depth of corrosion is calculated to be approximately $1.5 \mathrm{~mm}$ (rounded to two significant figures), which is $15 \%$ of the $9.5 \mathrm{~mm}$ tube wall thickness, as given in IED Interlocking Drip Shield and Emplacement Pallet [Sheet 1 of 1] (BSC 2005 [DIRS 173303], Table 6). Because this calculation is based on short-term corrosion measurements, and because corrosion rates tend to decrease with time, this is an upper limit of corrosion that would be expected.

In summary, chemical degradation of the emplacement pallet applies only to corrosion of the stainless steel connector tubes. Corrosion of the stainless steel ground support in the drifts does not significantly influence the in-drift chemistry (BSC 2005 [DIRS 175083], Section 8.1). Thus, corrosion of the pallet tubes, which are also constructed of stainless steel, can be excluded as factors influencing in-drift chemistry. Corrosion of the tubes does not significantly influence structural integrity, as discussed above. Corrosion of the Alloy 22 package supports is sufficiently slow that any degradation products may be neglected from the analysis presented in General Corrosion and Localized Corrosion of Waste Package Outer Barrier (BSC 2004 [DIRS 169984], Section 8.4.1).

Chemical degradation of the pallet is excluded from TSPA-LA because the magnitude and time of radiological exposures to the RMEI or radionuclide releases to the accessible environment would not be significantly changed by exclusion of this FEP. Mechanical degradation is discussed in Section 6.2.21 of this report under FEP 2.1.06.05.0A.

TSPA Disposition:

N/A

\section{Supporting Documents:}

N/A 


\subsubsection{Chemical Degradation of Invert}

\section{FEP Number:}

\subsection{D}

FEP Description: Degradation of the materials used in the invert may occur by chemical or microbial processes, and may affect the long-term performance of the repository.

\section{Screening Decision:}

Excluded (Low Consequence)

Screening Argument: The invert consists of a steel structure, gantry rails, and crushed tuff ballast materials, as shown in D\&E / PA/C IED Emplacement Drift Configuration and Environment (BSC 2004 [DIRS 168489], Figure 1). The steel invert structure will provide a framework, consisting of a series of beams bolted to the tunnel wall, that supports, along with the invert crushed tuff, the emplacement pallets, waste packages, and drip shields. It will also provide the support for the rails that support the gantry crane used for emplacement and retrieval of waste packages and installation of the drip shield (BSC 2004 [DIRS 168489], Figure 1).

Radionuclide transport occurs in the invert primarily in the invert ballast, which occupies separate regions of the invert than the invert steel or steel corrosion products. The invert ballast is composed of crushed tuff, which is not subject to corrosion in the same manner as the steel elements of the invert. Waste isolation performance of the invert occurs primarily when there is slow diffusion of released radionuclides, which can happen only when there is no advective liquid flux from drift seepage or drift-wall condensation. When such advective flux does occur, radionuclide transport is greatly enhanced, with advection dominating diffusion (BSC 2005 [DIRS 173433], Section 8).

Whereas dissolution/precipitation reactions within the invert ballast may occur and change the pore structure, these reactions require water that only occurs in the intragranular porosity of tuff particles, unless there is advective flow of seepage or condensation water. Reactions that increase the molar volume of pore-lining minerals, and decrease intra-granular porosity, will decrease the mobility of radionuclides by diffusion.

Whereas particles derived from steel corrosion products or from tuff ballast may migrate in the invert and change the inter-granular pore structure, the advective flow of water that is required can only occur in significant amounts when radionuclide transport is already enhanced by advective liquid flux. Changes in pore structure require accumulation of particles, and diffusion-only migration causes dispersal, so advection is required.

Oxygen consumption due to corrosion of committed materials, such as the invert steel structure, is evaluated in the in-drift gas composition calculations in Engineered Barrier System: Physical and Chemical Environment (BSC 2005 [DIRS 175083], Section 6.7). As discussed in that report, corrosion of carbon steel in the invert may cause an excursion of the repository into a low oxygen condition, but anoxic conditions will not exist.

Committed materials, including those in the invert, are included in an evaluation of in-drift microbial communities as sources of energy and nutrients to bacteria and other microorganisms 
that might survive in the in-drift environment, as discussed in Evaluation of Potential Impacts of Microbial Activities on Drift Chemistry (BSC 2004 [DIRS 169991], Section 6.4.5). Results of that analysis show that microbial activity is of low consequence with respect to the composition of the in-drift atmosphere (BSC 2004 [DIRS 169991], Section 7.1).

Degradation of the invert by chemical or microbial processes is excluded on the basis of low consequence because it will not alter the chemical environment of emplacement drifts sufficiently to affect predictions of repository chemistry. As such, its exclusion does not significantly change the magnitude and time of the resulting radiological exposures to the RMEI or radionuclide releases to the accessible environment.

Radiological effects on the invert are discussed in Section 6.2.82 of the present report under FEP 2.1.13.02.0A.

TSPA Disposition:

N/A

Supporting Documents:

N/A

\subsubsection{Effects of Drip Shield on Flow}

\section{FEP Number:}

2.1.06.06.0A

FEP Description: The drip shield will affect the amount of water reaching the waste package. Effects of the drip shield on the disposal region environment (for example, changes in relative humidity and temperature below the shield) should be considered for both intact and degraded conditions.

\section{Screening Decision:}

Included

\section{Screening Argument: N/A}

TSPA Disposition: The effects of the drip shield on flow are included in TSPA models for in-drift natural convection and condensation in In-Drift Natural Convection and Condensation (BSC 2004 [DIRS 164327]), and for EBS radionuclide transport in EBS Radionuclide Transport Abstraction (BSC 2005 [DIRS 173433]).

The role of the drip shield on flow processes in the in-drift environment is addressed in In-Drift Natural Convection and Condensation Model (BSC 2004 [DIRS 164327]), which develops a computational fluid dynamics model of natural convection during the postclosure period (BSC 2004 [DIRS 164327], Section 6.2.5). Axial dispersion coefficients of water vapor are derived from the natural convection model, and implemented in a simplified model of evaporation and condensation in the in-drift environment (BSC 2004 [DIRS 164327], Section 6.3.3). Condensation on the drift walls is discussed in more detail in Section 6.2.35 of 
the current report under FEP 2.1.08.04.0A. The results are included in TSPA-LA, as also described in Section 6.2.35 under FEP 2.1.08.04.0A.

The radionuclide transport abstraction (RTA) model in EBS Radionuclide Transport Abstraction (BSC 2005 [DIRS 173433]) quantifies the time-dependent radionuclide releases from a failed waste package and their subsequent transport through the EBS to the emplacement drift wall/UZ interface. The basic inputs to the RTA model, as described in EBS Radionuclide Transport Abstraction (BSC 2005 [DIRS 173433], Section 6.1), consist of the drift seepage influx, the environmental conditions in the drift (temperature, relative humidity, and water chemistry), and the degradation state of the EBS components. The EBS flow model is described in detail in EBS Radionuclide Transport Abstraction (BSC 2005 [DIRS 173433], Section 6.3.1.1). The discussion presented here summarizes the model.

Dripping flux comprises a major source of inflow to the EBS. As described in EBS Radionuclide Transport Abstraction (BSC 2005 [DIRS 173433], Section 6.3.2), an algorithm referred to as the drip-shield flux-splitting model is developed for calculating the fraction of flow diverted by the drip shield when breaches in the drip shield exist. Section 6.5.3 of that report (BSC 2005 [DIRS 173433]) describes a relationship for the fraction of seepage water flowing through the drip shield, and states that a uniform distribution (which maximizes uncertainty for a given mean standard deviation) is appropriate for this parameter.

Uncertainty in the fraction of flow diverted is accounted for by the drip-shield flux-splitting model as described in EBS Radionuclide Transport Abstraction (BSC 2005 [DIRS 173433], Section 6.3.2).

\section{Supporting Documents:}

BSC 2004 [DIRS 164327]

BSC 2005 [DIRS 173433]

\subsubsection{Chemical Effects at EBS Component Interfaces}

\section{FEP Number:}

2.1.06.07.0A

FEP Description: Chemical effects that occur at the interfaces between materials in the drift may affect the performance of the system.

\section{Screening Decision:}

Excluded (Low Consequence)

Screening Argument: Drip Shield and Waste Package Emplacement Pallet Design Report (BSC 2004 [DIRS 166879]) provides the design methodology for these EBS components. As discussed in that report (BSC 2004 [DIRS 166879], Section 5.2.2), the waste package emplacement pallet supports the waste package during handling, emplacement, preclosure, and postclosure periods, and is fabricated from stainless steel and Alloy 22, as described in IED Subsurface Facilities Committed Materials [Sheet 1 of 1] (BSC 2005 [DIRS 173871]). Stainless steel tubes connect Alloy 22 to waste package supports to form an emplacement pallet. The function of the tubes is to provide structural strength and long-term resistance to external loads 
on the pallet assembly (BSC 2004 [DIRS 166879], Section 5.2.2.2); the emplacement pallet function of keeping the waste package from contacting the invert is fulfilled by the Alloy 22 supports. The steel invert structure will provide a framework, consisting of a series of beams bolted to the invert rock mass, that supports the emplacement pallets, waste packages, and drip shields, as shown in D\&E / PA/C IED Emplacement Drift Configuration and Environment (BSC 2004 [DIRS 168489], Figure 1). It will also provide the support for the rails that support the gantry crane used for emplacement and retrieval of waste packages and installation of the drip shield, as shown in D\&E / PA/C IED Emplacement Drift Configuration and Environment (BSC 2004 [DIRS 168489], Figure 1).

Solid-solid contact either occurs or could occur between the drip shield and the invert, and between the emplacement pallet and the waste package or drip shield, or both. As described in Drip Shield and Waste Package Emplacement Pallet Design Report (BSC 2004 [DIRS 166879], Section 5.1.2), the base plates of the drip shield are fabricated from Alloy 22 to prevent direct contact between the titanium and steel members in the invert, thus minimizing electrochemical effects at this interface. The pallet pedestals are fabricated of Alloy 22, as is the waste package outer barrier (BSC 2004 [DIRS 166879], Section 5.2.2.2), thus precluding galvanic reactions at this interface.

Chemical effects at EBS interfaces are excluded from the TSPA analysis based on low consequence to radiological exposures to the RMEI and radionuclide releases to the accessible environment.

Hydride cracking of drip shield-ground support contact is addressed in Screening of Features, Events, and Processes in Drip Shield and Waste Package Degradation (BSC 2005 [DIRS 174995], Section 6.2.9, FEP 2.1.03.04.0B). The basic chemical processes that occur at liquid-solid phase boundaries are not considered part of this FEP, as they are included in Section 6.2.45 of the current report under FEP 2.1.09.01.0A.

Chemical effects at EBS component interfaces are excluded from the TSPA analysis based on low consequence to radiological exposures to the RMEI and radionuclide releases to the accessible environment. In summary, the magnitude and time of the resulting radiological exposures to the RMEI or radionuclide releases to the accessible environment would not be significantly changed by the exclusion of this FEP.

TSPA Disposition:

N/A

Supporting Documents:

N/A

\subsubsection{Mechanical Effects at EBS Component Interfaces}

\section{FEP Number:}

2.1.06.07.0B

FEP Description: Physical effects of steady-state contact (static loading) that occur at the interfaces between materials in the drift may affect the performance of the system. 


\section{Screening Decision:}

Excluded (Low Consequence)

Screening Argument: 2.1.06.07.0B, Mechanical Effects at EBS Component Interfaces, is shared with Screening of Features, Events, and Processes in Drip Shield and Waste Package Degradation (BSC 2005 [DIRS 174995], Section 6.2.21). Drip Shield and Waste Package Emplacement Pallet Design Report (BSC 2004 [DIRS 166879]) provides the design methodology for these EBS components. As discussed in that report (BSC 2004 [DIRS 166879], Section 5.2), the waste package emplacement pallet supports the waste package during handling, emplacement, preclosure, and postclosure periods, and is fabricated from Stainless Steel Type 316L and Alloy 22. Stainless steel tubes connect Alloy 22 to waste package supports to form an emplacement pallet. The function of the tubes is to facilitate handling of the emplacement pallet during the preclosure period; the emplacement pallet function of keeping the waste package from contacting the invert is fulfilled by the Alloy 22 supports. The steel invert structure will provide a framework, consisting of a series of beams bolted to the invert rock mass, that supports the emplacement pallets, waste packages, and drip shields, as shown in D\&E/ PA/C IED Emplacement Drift Configuration and Environment (BSC 2004 [DIRS 168489], Figure 1). It will also provide the support for the rails that support the gantry crane used for emplacement and retrieval of waste packages and installation of the drip shield, as documented in D\&E / PA/C IED Emplacement Drift Configuration and Environment (BSC 2004 [DIRS 168489], Figure 1). As shown in IED Interlocking Drip Shield and Emplacement Pallet [Sheet 1 of 1] (BSC 2005 [DIRS 173303]), the base plates of the drip shield are fabricated from Alloy 22 to prevent direct contact between the titanium and steel members in the invert, thus minimizing electrochemical effects at this interface.

The waste package is capable of self-support when resting on the emplacement pallet, including a corrosion allowance for 10,000 years of general corrosion. This is documented in Commercial SNF Waste Package Design Report (BSC 2004 [DIRS 169766], Section 7.1.1.2.5). The maximum stress of $116 \mathrm{MPa}$ at the waste package/pallet interface (BSC 2004 [DIRS 169766], Section 7.1.1.2.5) is also well below the threshold stress required for the initiation of stress corrosion cracks, as reported in Stress Corrosion Cracking of the Drip Shield, the Waste Package Outer Barrier, and the Stainless Steel Structural Material (BSC 2004 [DIRS 172203], Table 8.1). Further, as documented in Section 7.1.1 of Drip Shield and Waste Package Emplacement Pallet Design Report (BSC 2004 [DIRS 166879]), the emplacement pallet will not deform either as a result of handling or during performance of the function of supporting the waste package in the drift.

Mechanical loading at the drip shield/invert interface occurs between the Alloy 22 drip shield base plates and carbon steel components of the invert (BSC 2004 [DIRS 166879], Section 5.1.2). Loads can result from thermal expansion of the base plates, drip shield, or invert steel structure; rock movement due to in situ stress release from excavation; and rock deformation of the invert. The impact of a seismic event on the drip shield is assessed in Seismic Consequence Abstraction (BSC 2005 [DIRS 173247], Sections 6.3.3, 6.3.6, and 6.5.5), which shows that the drip shield will continue to function with the loads imposed by rockfall. These have been analyzed in Evaluation of Emplacement Drift Stability for KTI Resolutions (BSC 2004 [DIRS 168889]), as described in Section 6.2.22 of the current report under FEP 2.1.06.05.0B. The design of the carbon steel structure in the invert accounts for the loads imposed by construction activities, the 
gantry crane, waste packages, waste package pallet, drip shield, and seismic and thermal loads, as discussed in D\&E / PA/C IED Emplacement Drift Configuration and Environment (BSC 2004 [DIRS 168489], Figure 1).

The analyses discussed here demonstrate that loading between EBS components has minimal impact on the long-term performance of these components. Therefore, the physical effects of steady-state contact (static loading) that occur at the interfaces between materials in the drift will not have a significant effect on long-term repository performance. The magnitude and time of the resulting radiological exposures to the RMEI or radionuclide releases to the accessible environment would not be significantly changed by exclusion of this FEP.

TSPA Disposition:

N/A

Supporting Documents:

$\mathrm{N} / \mathrm{A}$

\subsubsection{Rockfall}

FEP Number:

2.1.07.01.0A

FEP Description: Rockfalls may occur with blocks that are large enough to mechanically tear or rupture drip shields and/or waste packages. Seismic-induced rockfall is addressed in a separate FEP.

\section{Screening Decision:}

Excluded (Low Consequence)

Screening Argument: FEP 2.1.07.01.0A, Rockfall, is shared with Screening of Features, Events, and Processes in Drip Shield and Waste Package Degradation (BSC 2005 [DIRS 174995], Section 6.2.22) and Clad Degradation - FEPs Screening Arguments (BSC 2004 [DIRS 170019], Section 6.2.18). All emplacement drift areas will be circular in cross-section and excavated with a tunnel-boring machine (BSC 2005 [DIRS 174514], Section 2.3.2). This excavation method produces a nominally circular opening with a predominately smooth surface profile. This is the least destructive technique for excavation since excessive energy (as in blasting) is not used for breakage of the rock.

Nominal rockfall may result from in situ conditions of gravitational stresses, excavation-induced stresses and thermally induced stresses, as described in Drift Degradation Analysis (BSC 2004 [DIRS 166107], Section 6). Nominal rockfall does not include dynamic loading caused by seismic events, defined here as ground motions with a probability of exceedance of greater than $5 \times 10^{-4}$. Calculations of potential rockfall for the nonlithophysal and lithophysal layers of the repository for nominal and seismic scenarios are described in detail in Drift Degradation Analysis (BSC 2004 [DIRS 166107], Sections 6.3 and 6.4). In nonlithophysal rock, the maximum rockfall block mass predicted for the preclosure seismic case is 2.72 metric tons with a median block size of 0.10 metric ton and a total rockfall volume of $39.4 \mathrm{~m}^{3}$ (BSC 2004 [DIRS 166107], Section 6.3.1.2.6). The nominal scenario in nonlithophysal rock, which includes 
thermal loading and excludes seismic loading, results in a minor amount of rockfall (BSC 2004 [DIRS 166107], Section 6.3.1.3). The calculations show that the formation of small blocks that fall under gravitational forces is expected to be the dominant potential failure mode of drifts in lithophysal rocks, thus precluding the potential to tear or rupture drip shields or waste packages (BSC 2004 [DIRS 166107], Section 6.4.3). In the nonlithophysal rocks, static fatigue failure of roughness along fracture surfaces is possible and would result in gravitationally induced failure of large blocks. For both lithophysal and nonlithophysal zones, the potential consequences of rockfall are damage to the drip shields and waste packages. The rock mass surrounding the excavations may undergo over-stressing from thermal heating and/or time-dependent damage associated with static fatigue resulting from stress corrosion mechanisms (BSC 2004 [DIRS 166107], Section 6.3.1.5). Another likely long-term effect includes the increasing amounts of moisture/air induced weathering along the joints close to the tunnels. This damaged and/or weathered material may result in block fallout in the nonlithophysal units (BSC 2004 [DIRS 166107], Section 6.3.1.5).

In the calculations relating to rockfall in Drift Degradation Analysis (BSC 2004 [DIRS 166107], Section 6), the approach is taken to ignore the potential for drift stability afforded by ground control systems. As discussed in Subsurface Facility Description Document (BSC 2005 [DIRS 174514], Sections 3.1.1.10.16 and 4.1.1.2), a substantial ground support system will be installed in the emplacement drifts to facilitate repository operations. The ground support structure will be fabricated of stainless steel for longevity (BSC 2005 [DIRS 173871]), as described in IED Subsurface Facilities Ground Support Configuration [Sheet 1 of 1] (BSC 2005 [DIRS 173498]). Analyses of possible damage to EBS components have been conducted. Results of block formation and failure presented in Drift Degradation Analysis (BSC 2004 [DIRS 166107], Sections 6.3 and 6.4) provide input to these analyses in the form of block size and frequency of gravitationally induced failures.

A design requirement presented in Subsurface Facility Description Document (BSC 2005 [DIRS 174514], Section 3.1.1.16.1) specifies that the drip shield protect the waste packages from rockfall during postclosure. An analysis of the drip shield response to seismic-induced rockfall is presented in Section 6.2.9 of the current report under FEP 1.2.03.02.0B. That analysis considers blocks that are much larger than the blocks used in the nominal rockfall case (addressed in this FEP). The highest energy blocks considered in the seismic rockfall analysis will not create deflections of the drip shield great enough to contact the waste package (Section 6.2.9 of the current report). Thus the drip shield provides adequate protection from impacts to the waste package from rockfall.

Analyses related to multiple rockfalls were conducted in Multiple Rock Fall on Drip Shield (BSC 2004 [DIRS 171756]). Bounding characteristics of the credible multiple rock falls for postclosure were used in the calculation. The structural response of the drip shield to two identical 2-metric ton rock block impacts onto the same location was analyzed. It was concluded that the wall-averaged total stress intensities through the drip shield top plate and the maximum bending surface principal stress in the longitudinal stiffeners do not exceed the respective true tensile strengths of titanium, as discussed in Multiple Rock Fall on Drip Shield (BSC 2004 [DIRS 171756], Section 6.1). 
The effects of rockfall on crack initiation in the drip shield are discussed in the screening argument for FEP 2.1.03.10.0B, Advection of Liquids and Solids through Cracks in the Drip Shield (Section 6.2.64 of the current report), including the potential for water to penetrate rockfall-induced cracks in the drip shield.

Since the drip shield continues to function through rockfall events as described above, the waste package and cladding will be protected from rockfall during the postclosure period. During the preclosure period (prior to the installation of the drip shield), the effects of the maximum effective plastic strain on the waste package structural response to multiple rockfalls is small, and does not cause waste package failure, as discussed in Rock Fall on Waste Packages (BSC 2004 [DIRS 167182], Section 6).

Seismic induced rockfall is addressed in a separate section of the current report (Section 6.2.9 under FEP 1.2.03.02.0B). Thermal effects on rockfall in the lithophysal units are discussed in Section 6.2.29 under FEP 2.1.07.02.0A.

In summary, rockfall will not have a significant effect on the magnitude and time of the resulting radiological exposures to the RMEI or radionuclide releases to the accessible environment.

TSPA Disposition:

N/A

Supporting Documents:

N/A

\subsubsection{Drift Collapse}

\section{FEP Number:}

2.1.07.02.0A

FEP Description: Partial or complete collapse of the drifts, as opposed to discrete rockfall, could occur as a result of thermal effects, stresses related to excavation, or other mechanisms. Drift collapse could affect the stability of the engineered barriers and waste packages and/or result in static loading from rock overburden. Rockfalls of small blocks may produce rubble throughout part or all of the drifts. Seismic-induced drift collapse is addressed in a separate FEP.

\section{Screening Decision:}

Excluded (Low Consequence)

Screening Argument: This FEP addresses nominal drift collapse effects. Drift Degradation Analysis (BSC 2004 [DIRS 166107]) provides analysis of drift degradation for both nonlithophysal and lithophysal rock. A summary of the analysis and results of the analysis are given in Section 8.1 of that report (BSC 2004 [DIRS 166107]). Section 6.3 of Drift Degradation Analysis (BSC 2004 [DIRS 166107]) provides a nonlithophysal rockfall model developed using the three-dimensional discontinuum code 3DEC, while Section 6.4 of that report provides a lithophysal rockfall model developed using the two-dimensional discontinuum code UDEC. The lithophysal rockfall model allows for the formation of stress-induced fractures between blocks (i.e., the formation of internal fracturing), and separation and instability (under the action of 
gravity or seismic shaking) of the rock mass around the drift (BSC 2004 [DIRS 166107], Section 6.4.2.1). In both models, appropriate thermal and mechanical properties of rock blocks and joints are used.

Thermally induced stresses at any location depend on the proximity and timing of waste emplacement, the amount of heat generated, the age of the waste, packaging and emplacement configuration, and the thermal-mechanical properties of the rock mass. Thermal stresses are time-dependent and are calculated over the 10,000-year period after repository closure.

The rock mass surrounding the emplacement drifts may undergo over-stressing from thermal heating or time-dependent damage associated with static fatigue resulting from stress corrosion mechanisms. This damaged material may result in a slow unraveling (lithophysal rock) or block fallout (nonlithophysal rock). In the nonlithophysal rocks, static fatigue failure of roughness along fracture surfaces is possible and could result in gravitationally induced block failures. Fatigue failure would presumably initiate along asperities on fracture surfaces, reducing the effective friction angle along the fracture surfaces (BSC 2004 [DIRS 166107], Section 6.3.1.5). In the case of the lithophysal rocks, the compressive stress concentrations along the immediate rib springline of the emplacement drifts will be at or near the uniaxial compressive strength, so static fatigue failure is possible. The analyses of the available static-fatigue test data indicate that an approximate 40\% reduction in cohesive strength occurs over a 20,000-year period (BSC 2004 [DIRS 166107], Appendix S, Section S3.4.1). The nominal case for drift degradation (i.e., considering thermal and time-dependent effects, but excluding seismic effects) results in only partial collapse of the drift over the 10,000-year regulatory period for postclosure performance (BSC 2004 [DIRS 166107], Section 8.1).

Drift Degradation Analysis (BSC 2004 [DIRS 166107]) reports analyses of rockfall in the lithophysal and nonlithophysal units that provide time history of "expected" rockfall due to ongoing degradation of the drift. Furthermore, based on other analyses presented in that report (BSC 2004 [DIRS 166107], Sections 6.3 and 6.4), it can be summarized that only minor degradation or collapse of drift (including enlargement) will occur for the static (i.e., nonseismic) loading case, where the net effect can be sustained by the drip shield. This minor degradation would result in only minor and localized deviations from the currently predicted thermal and hydrologic conditions, and minimal consequences to the EBS components.

In the calculations relating to rockfall in Drift Degradation Analysis (BSC 2004 [DIRS 166107], Section 6), the approach is taken to ignore the potential for drift stability afforded by ground control systems. As discussed in Subsurface Facility Description Document (BSC 2005 [DIRS 174514], Sections 3.1.1.10.16 and 4.1.1.2), a substantial ground support system will be installed in the emplacement drifts to facilitate repository operations. The ground support structure will be fabricated of stainless steel for longevity (BSC 2005 [DIRS 173871]), as shown in IED Subsurface Facilities Ground Support Configuration [Sheet 1 of 1] (BSC 2005 [DIRS 173498]).

Seismic-induced drift collapse damage is addressed in Section 6.2.10 of the current report under FEP 1.2.03.02.0C, and seismic-induced drift collapse effects on thermal hydrologic processes are addressed in Section 6.2.11 under FEP 1.2.03.02.0D. The potential for water to penetrate cracks caused by seismic induced rockfall on drip shields is given in the screening argument for FEP 
2.1.03.10.0B, Advection of Liquids and Solids through Cracks in the Drip Shield (Section 6.2.64 of the current report).

Thus, drift collapse under nominal (static) loading conditions will not have a significant effect on long-term performance of the repository. Omission of this FEP on the basis of low consequence does not change the magnitude and time of the resulting radiological exposures to the RMEI or radionuclide releases to the accessible environment.

TSPA Disposition:

N/A

Supporting Documents:

$\mathrm{N} / \mathrm{A}$

\subsubsection{Hydrostatic Pressure on Waste Package}

\section{FEP Number:}

2.1.07.04.0A

FEP Description: Waste packages emplaced in the saturated zone will be subjected to hydrostatic pressure in addition to stresses associated with the evolution of the waste and EBS.

\section{Screening Decision:}

Excluded (Low Probability)

Screening Argument: The repository horizon lies well above (approximately $300 \mathrm{~m}$ ) the water table, as documented in D\&E/RIT IED Subsurface Facilities [Sheet 1 of 4] (BSC 2004 [DIRS 172801], Table 2, for repository elevation, which ranges from 1,065 to $1,107 \mathrm{~m}$ ) and in Development of Numerical Grids for UZ Flow and Transport Modeling (BSC 2004 [DIRS 169855], Figure 6-2, for water table elevation, which is $730 \mathrm{~m}$ ). Saturated Zone Site-Scale Flow Model (BSC 2004 [DIRS 170037]) discusses estimates of water table rise from climate change. According to that report (BSC 2004 [DIRS 170037], Section 6.4.5.1), estimates of the elevation of the water table under Yucca Mountain for wetter, glacial climatic conditions indicate that the water table could be on the order of $100 \mathrm{~m}$ higher than present conditions. Even under these extreme conditions, however, the repository would still be above the water table. As corroboration, according to Forester et al. (1999 [DIRS 109425], p. 57), the historical water table (approximately 500,000 years) has never risen to the level of the repository.

Consequently, this FEP is not relevant for the YMP design, which calls for emplacement in the $\mathrm{UZ}$, and can be excluded on the basis of low probability.

\section{TSPA Disposition:}

N/A

\section{Supporting Documents: \\ N/A}




\subsubsection{Hydrostatic Pressure on Drip Shield}

FEP Number:

2.1.07.04.0B

FEP Description: Drip shields emplaced in the saturated zone will be subjected to hydrostatic pressure in addition to stresses associated with the evolution of the waste and EBS.

\section{Screening Decision:}

Excluded (Low Probability)

Screening Argument: The repository horizon lies well above (approximately $300 \mathrm{~m}$ ) the water table, as documented in D\&E/RIT IED Subsurface Facilities [Sheet 1 of 4] (BSC 2004 [DIRS 172801], Table 2, for repository elevation, which ranges from 1,065 to $1,107 \mathrm{~m}$ ), and in Development of Numerical Grids for UZ Flow and Transport Modeling (BSC 2004 [DIRS 169855], Figure 6-2, for water table elevation, which is $730 \mathrm{~m}$ ). Saturated Zone Site-Scale Flow Model (BSC 2004 [DIRS 170037]) discusses estimates of water table rise from climate change. According to that report (BSC 2004 [DIRS 170037], Section 6.4.5.1), estimates of the elevation of the water table under Yucca Mountain for wetter, glacial climatic conditions indicate that the water table could be on the order of $100 \mathrm{~m}$ higher than present conditions. Even under these extreme conditions, however, the repository will still be above the water table. As corroboration, according to Forester et al. (1999 [DIRS 109425], p. 57), the historical water table (approximately 500,000 years) has never risen to the level of the repository.

Consequently, this FEP is not relevant for the YMP design, which calls for emplacement in the $\mathrm{UZ}$, and can be excluded on the basis of low probability.

\section{TSPA Disposition:}

N/A

\section{Supporting Documents:}

N/A

\subsubsection{Floor Buckling}

\section{FEP Number:}

2.1.07.06.0A

FEP Description: Buckling, or heave, of the drift floor may occur in response to changing stress. Floor buckling may affect the performance of EBS components such as the drip shield, the invert, and the pallet. Effects may include movement of EBS components and changes in the topography of the surface of the drift floor and invert that may affect water flow.

\section{Screening Decision:}

Excluded (Low Consequence)

Screening Argument: The effect of floor heave and buckling on drip shield response has been screened out of the TSPA because of low consequence. Consideration of floor heave is centered 
on thermal stressing and excavation stress unloading. Calculations documented in Evaluation of Emplacement Drift Stability for KTI Resolutions (BSC 2004 [DIRS 168889], Table 6.4-3) demonstrated that the vertical displacement of the floor due to in situ stress and thermal response will be less than $1 \mathrm{~mm}$ per $6 \mathrm{~m}$ of drift. This displacement will produce only minor shifting in the drip shields and will not compromise their integrity because the overlap between adjacent drip shields is approximately $320 \mathrm{~mm}$, as shown in Design and Engineering, Interlocking Drip Shield Configuration (BSC 2004 [DIRS 168067]). The effect of floor heave on position of the waste packages is also minor. A displacement of $1 \mathrm{~mm}$ at one end of a 5,000-mm-long package results in an angle of inclination of less than one degree. Because of the limited vertical displacement of the floor, pallet displacement and damage to invert will also be minor. The impacts of floor heave and buckling have therefore been screened out of the TSPA.

In summary, the omission of floor buckling will not have a significant effect on the magnitude and time of the resulting radiological exposures to the RMEI or radionuclide releases to the accessible environment.

TSPA Disposition:

N/A

Supporting Documents:

N/A

\subsubsection{Effects of Rapid Influx into the Repository}

\section{FEP Number:}

2.1.08.01.0B

FEP Description: Extremely rapid influx could reduce temperatures below the boiling point during part or all of the thermal period. Increases in flux could result from climate change, but the cause of the increase is not an essential part of the FEP.

\section{Screening Decision:}

Excluded (Low Consequence)

Screening Argument: A potential concern regarding rapid influx is that it could thermally quench a waste package or drip shield, leading to waste package breach during all or part of the thermal period. Rapid influx is only possible if the flow itself is episodic. The repository horizon lies in the UZ well above the water table, as documented in D\&E/RIT IED Subsurface Facilities [Sheet 1 of 4] (BSC 2004 [DIRS 172801], Table 2, for repository elevation) and in Development of Numerical Grids for UZ Flow and Transport Modeling (BSC 2004 [DIRS 169855], Figure 6-2, for water table elevation). Flow in the UZ above the drifts from condensation zones may result in episodic and preferential flow patterns. This type of condition is addressed in Abstraction of Drift Seepage (BSC 2004 [DIRS 169131], Section 6.4.3.2), where it is shown that the penetration of such flow episodes is not expected when the boiling zone is large due to high temperatures of the waste form. When the boiling zone is more limited, arrivals are expected to be diverted by the drift's capillary barrier. 
The effect of infiltration flux on peak postclosure drift wall temperature is illustrated in Tables 6.3-5 and 6.3-6 of Multiscale Thermohydrologic Model (BSC 2005 [DIRS 173944]). This table shows that the variation in median drift-wall temperature ranges from 131.6 to $135.4^{\circ} \mathrm{C}$ for the percolation flux ranging from the upper infiltration case $(10.84 \mathrm{~mm} / \mathrm{year})$ to the lower infiltration case $(0.41 \mathrm{~mm} /$ year $)$. This range is $3.8^{\circ} \mathrm{C}$ and is not considered significant because the range due to thermal conductivity is 21.4 to $29.8^{\circ} \mathrm{C}$ (depending on location), as shown in Table 6.3-25 of Multiscale Thermohydrologic Model (BSC 2005 [DIRS 173944]).

Although precipitation is episodic, UZ Flow Models and Submodels (BSC 2004 [DIRS 169861]) conceptualizes UZ flow as steady at the repository horizon and along potential radionuclide transport pathways. The report shows (BSC 2004 [DIRS 169861], Sections 6.1.2 and G.4) that the PTn unit dampens and homogenizes downward-moving transient pulses arising from episodic surface infiltration events. This dampening of the transient flow is due to the fact that the PTn has high porosity and low fracture density, and a matrix of relatively high permeability and porosity; thus, it has a large capacity for storing groundwater (BSC 2004 [DIRS 169861], Section 6.2.2). This conclusion is based on a study by $\mathrm{Wu}$ et al. (2000 [DIRS 154918], Section 4.1 and Figure 4.1-11).

Other mechanisms for generating rapid influx such as wetter climates and flow focusing are included in the drift seepage abstraction model (BSC 2004 [DIRS 169131], Section 6.6.5.1 for future climate changes, and Section 6.6.5.2 for flow focusing). Because the flow in the UZ at the repository horizon is relatively steady, it follows that the seepage flux that enters the crown of the drift is also steady. For the reasons discussed above, the chance for contact between a waste package and a significant quantity of liquid water in the drift is very limited. If seepage enters the drift, the drip shield will protect the waste package and pallet from direct contact with the seepage, and thus the waste package will be protected from the potential effects of quenching. However, if the condition is assumed where a significant quantity of liquid water contacts a waste package, the following two scenarios could be considered:

1. Waste form temperatures are marginally greater than boiling temperatures:

At the waste package surface, the water will initially flash and then equilibrate at a temperature just below boiling temperatures. The flashing condition will not result in any material quenching that affects material properties of the waste package because the absolute temperatures are low with regard to any metallurgical effects such as phase composition or stability. Phase alterations were found to be inconsequential at temperatures above $500^{\circ} \mathrm{C}$ for long durations. Thus, deleterious effects are not predicted to occur in the repository conditions where waste package temperatures are predicted to be less than $300^{\circ} \mathrm{C}$, as discussed in Aging and Phase Stability of Waste Package Outer Barrier (BSC 2004 [DIRS 171924], Section 8). The temperature gradient in the outer corrosion barrier vessel will be small and insignificant thermal stresses would result.

2. Waste form temperatures are below boiling temperatures:

Here, the same arguments described above are valid with the exception that flashing of steam will not occur on the waste package surface. 
FEP 2.1.08.01.0B is excluded from TSPA-LA on the basis of low consequence because variation in flux, either as infiltration above the repository or as percolation at the repository level, has been shown to not significantly influence repository temperature behavior. In addition, the drip shield will protect the waste package and pallet from direct contact with the seepage. Therefore, omission of the effects of rapid influx from the TSPA-LA will not significantly change the magnitude and time of resulting radiological exposures to the RMEI or radionuclide releases to the accessible environment.

TSPA Disposition:

N/A

\section{Supporting Documents:}

N/A

\subsubsection{Repository Dry-Out Due to Waste Heat}

\section{FEP Number:}

2.1.08.03.0A

FEP Description: Repository heat evaporates water from the UZ rocks near the drifts, as the temperature exceeds the vaporization temperature. This zone of reduced water content (reduced saturation) could migrate outward during the heating phase and then migrate back to the waste package as heat diffuses throughout the mountain and the radioactive heat sources decay. This FEP addresses the effects of dry-out within the repository drifts.

\section{Screening Decision:}

Included

\section{Screening Argument:}

N/A

TSPA Disposition: The postclosure in-drift thermal and hydrologic conditions are calculated in accordance with the methodology presented in Multiscale Thermohydrologic Model (BSC 2005 [DIRS 173944]). This includes a calculation of the postclosure thermohydrologic conditions, including dryout during the heating phase and rewetting during the cooling phase. Using the modeling methodology described in that report (BSC 2005 [DIRS 173944], Section 6.2), the repository dryout is implemented in TSPA-LA by MSTHM output variables of temperature, relative humidity, and invert saturation at waste package locations throughout the repository. These output variables are direct feeds to the TSPA-LA.

Additional considerations of evaporation/condensation is discussed as part of FEPs 2.1.08.04.0A and 2.1.08.04.0B (Sections 6.2.35 and 6.2.36, respectively, of the current report).

Ventilation Model and Analysis Report (BSC 2004 [DIRS 169862], Section 8.1) calculates the preclosure thermal conditions in the host rock, and characterizes the preclosure host rock response in terms of ventilation efficiency. The ventilation efficiency is the fraction of total decay heat removed from the repository by the vent air. The ventilation efficiency is determined through simulation of temporally and spatially dependent heat transfer processes (thermal 
radiation, convection, and conduction), which occur simultaneously in the drift and the surrounding rock mass during the ventilating or preclosure period. The ventilation efficiency is a direct input to Multiscale Thermohydrologic Model (BSC 2005 [DIRS 173944]), which in turn provides postclosure thermal conditions to the TSPA-LA. Because the uncertainty in the ventilation efficiency (which includes the effects of dryout on the host rock thermal conductivity) can be propagated to downstream models, the effect of dryout on the ventilation efficiency can be included in the MSTHM.

\section{Supporting Documents:}

BSC 2004 [DIRS 169862]

BSC 2005 [DIRS 173944]

\subsubsection{Condensation Forms on Roofs of Drifts (Drift-Scale Cold Traps)}

\section{FEP Number:}

2.1.08.04.0A

FEP Description: Emplacement of waste in drifts creates thermal gradients within the repository. Such thermal gradients can lead to drift-scale cold traps characterized by latent heat transfer from warmer to cooler locations. This mechanism can result in condensation forming on the roof or other parts of the drifts, leading to enhanced dripping on the drip shields, waste packages, or exposed waste material.

\section{Screening Decision:}

Included

\section{Screening Argument: N/A}

TSPA Disposition: Cold-trap effects within the emplacement drift between the drift wall and the drip shield are represented in the TSPA-LA by the condensation model documented in In-Drift Natural Convection and Condensation (BSC 2004 [DIRS 164327], Section 8.3). FEPs related to this FEP are discussed in Sections 6.2.36 and 6.2.43 of the current document under FEPs 2.1.08.04.0B and 2.1.08.14.0A, respectively. The condensation model is a one-dimensional network model that produces estimates for the frequency and magnitude of condensation at waste package locations. Condensation on the drift walls is included in the TSPA-LA and is represented in the same manner as drift seepage, although with a different spatial distribution and flux rate. As such, it affects the transport of radionuclides through the drift invert and the partitioning of that transport into the fractures and the matrix of the host rock.

The condensation analysis (BSC 2004 [DIRS 164327], Section 6.3) assesses condensation and evaporation rates along the entire length of seven selected drifts at different times $(1,000,3,000$, and 10,000 years); the drift nearest the edge of the repository was also assessed at 300 years. Calculations implemented in TSPA-LA assume that the gas underneath the drip shield mixes readily with air external to the drip shield, resulting in a "well-ventilated" drip shield configuration (BSC 2004 [DIRS 164327], Section 8.3.1.2). Postclosure Modeling and Analyses Design Parameters (BSC 2004 [DIRS 169885], Table 10) specifies that the drip shield will allow airflow exchange between the spaces inside and outside the drip shield. 
As described in In-Drift Natural Convection and Condensation (BSC 2004 [DIRS 164327], Section 6.3.3), sources of water are available at each waste package location at the drift wall and the invert. The local vapor pressure is the saturation pressure at the calculated temperature. The rate of water evaporation is based on (1) the local vapor pressure difference between the evaporating surface and the local partial pressure of water, and (2) the corresponding mass transfer correlation. The rate is limited by the availability of water to the surface by capillary pumping and percolation values. Local vapor pressure is calculated in the condensation network model for two assumptions. The first, referred to as the "high-invert" transport, assumes that the local vapor pressure is controlled by the temperature calculated at the top of the invert. This temperature is higher than that calculated at the base of the invert (which is identical to that at the drift wall in the condensation network model). The second, referred to as the "low-invert" transport, assumes the local vapor pressure is controlled by the temperature at the base of the invert (i.e., the drift wall temperature in the condensation network model).

The water vapor is transported along the drift by a one-dimensional axial dispersion model using the dispersion coefficients calculated by the in-drift convection model (BSC 2004 [DIRS 164327], Section 6.3.5.1).

A total of four cases are implemented in TSPA-LA for condensation on the drift wall as follows (BSC 2004 [DIRS 164327], Section 8.3.1):

- High-invert transport, low axial dispersion

- Low-invert transport, low axial dispersion

- High-invert transport, high axial dispersion

- Low-invert transport, high axial dispersion.

Condensate dripping from drift walls affects TSPA-LA model calculations by adding additional water to the volumetric flow through the invert and, in some cases, through the waste packages and waste forms. The model implemented in TSPA-LA calculates a probability of condensate on the drift walls at any location and, if condensation occurs, rate of condensation. The probability of condensation occurrence and condensation rate are abstracted as functions of the percolation flux, as described in In-Drift Natural Convection and Condensation (BSC 2004 [DIRS 164327], Section 8.3.1).

The model developed in EBS Radionuclide Transport Abstraction (BSC 2005 [DIRS 173433], Section 8.1) is used to quantify the release of radionuclides from the EBS to the UZ. Dripping flux comprises a major source of liquid flow into the EBS. Condensation represents one source of dripping flux into the radionuclide transport model (BSC 2005 [DIRS 173433], Section 8.1). The EBS flow model is implemented directly in the TSPA-LA, as discussed in Section 8.1 of EBS Radionuclide Transport Abstraction (BSC 2005 [DIRS 173433]).

\section{Supporting Documents:}

BSC 2004 [DIRS 164327]

BSC 2005 [DIRS 173433]

BSC 2005 [DIRS 173944] 


\subsubsection{Condensation Forms at Repository Edges (Repository-Scale Cold Traps)}

\section{FEP Number:}

2.1.08.04.0B

FEP Description: Emplacement of waste in drifts creates thermal gradients within the repository. Such thermal gradients can lead to repository-scale cold traps characterized by latent heat transfer from warmer to cooler locations. This mechanism can result in condensation forming at repository edges or elsewhere in the EBS, leading to enhanced dripping on the drip shields, waste packages, or exposed waste material.

\section{Screening Decision:}

Included

\section{Screening Argument: N/A}

TSPA Disposition: Cold-trap effects within the emplacement drift between the drift wall and the drip shield are represented in the TSPA-LA by the condensation model documented in In-Drift Natural Convection and Condensation (BSC 2004 [DIRS 164327], Section 8.3). FEPs related to this FEP are discussed in Sections 6.2.35 and 6.2.43 of the current document under FEPs 2.1.08.04.0A and 2.1.08.14.0A, respectively. The condensation model is a one-dimensional network model that produces estimates for the frequency and magnitude of condensation at waste package locations. Condensation on the drift walls is included in the TSPA-LA and is represented in the same manner as drift seepage, although with a different spatial distribution and flux rate. As such, it affects the transport of radionuclides through the drift invert and the partitioning of that transport into the fractures and the matrix of the host rock.

Seven drifts in the repository are analyzed for condensation location and quantity as shown in the convection and condensation report (BSC 2004 [DIRS 164327], Figure 6.3.7-1). These drifts are chosen to reflect the range of conditions expected in the repository. Choices \#1, \#2, and \#3 are collinear (having axes lying end to end in a straight line) and cut across the northern end of the repository. Choice \#3 is shorter than most emplacement drifts and is at the edge of the repository. Choices \#4, \#5, and \#6 are collinear and cut across the middle of the repository. Choice \#7 is in the southern section of the repository.

The condensation analysis (BSC 2004 [DIRS 164327], Section 6.3) assesses condensation and evaporation rates along the entire length of the seven selected drifts at different times $(1,000$, 3,000 , and 10,000 years); the drift nearest the edge of the repository was also assessed at 300 years. Calculations implemented in TSPA-LA assume that the gas underneath the drip shield mixes readily with air external to the drip shield, resulting in a "well-ventilated" drip shield configuration. Postclosure Modeling and Analyses Design Parameters (BSC 2004 [DIRS 169885], Table 10) specifies that the drip shield will allow airflow exchange between the spaces inside and outside the drip shield.

The effects of repository-scale condensation are captured within the convection and condensation model described above. The temperature effects resulting from proximity to the drift edge are modeled as described in the accompanying report (BSC 2004 [DIRS 164327], 
Section 6.3.5.1.1). Drifts at the north end of the repository reflect the cooler portion of the repository, and drifts in the middle reflect the hotter portions of the repository (BSC 2004 [DIRS 164327], Section 6.3.5.1.1 and Figure 6.3.5-2). The effects of moisture being driven from hot areas in the repository and becoming available for condensation in cooler regions are captured in the bounding percolation rates. The bounding percolation rates are incorporated for each of the times and each of the emplacement drifts. The percolation rates vary with both location and time (BSC 2004 [DIRS 164327], Section 6.3.5).

As described in In-Drift Natural Convection and Condensation (BSC 2004 [DIRS 164327], Section 6.3.3), sources of water are available at each waste package location at the drift wall and the invert. The local vapor pressure is the saturation pressure at the calculated temperature. The rate of water evaporation is based on the local vapor pressure difference between the evaporating surface and the local gas vapor pressure and the corresponding mass transfer correlation. The rate is limited by the availability of water to the surface by capillary pumping and percolation values. Local vapor pressure is calculated in the condensation network model for two assumptions. The first, referred to as the "high-invert" transport, assumes the local vapor pressure is controlled by the temperature calculated at the top of the invert. This temperature is higher than that calculated at the base of the invert (which is identical to that at the drift wall in the condensation network model). The second, referred to as the "low-invert" transport, assumes that the local vapor pressure is controlled by the temperature at the base of the invert (i.e., the drift wall temperature in the condensation network model).

The water vapor is transported along the drift by a one-dimensional axial dispersion model using the dispersion coefficients calculated by the in-drift convection model (BSC 2004 [DIRS 164327], Section 6.3.5.1).

A total of four cases are implemented in TSPA-LA for condensation on the drift wall as follows (BSC 2004 [DIRS 164327], Section 8.3.1):

- High-invert transport, low axial dispersion

- Low-invert transport, low axial dispersion

- High-invert transport, high axial dispersion

- Low-invert transport, high axial dispersion.

Condensate dripping from drift walls affects TSPA-LA model calculations by adding additional water to the volumetric flow through the invert and, in some cases, through the waste packages and waste forms. The model implemented in TSPA-LA calculates a probability of condensate on the drift walls at any location and, if condensation occurs, rate of condensation. The probability of condensation occurrence and condensation rate are abstracted as functions of the percolation flux, as described in In-Drift Natural Convection and Condensation (BSC 2004 [DIRS 164327], Section 8.3.1).

The model developed in EBS Radionuclide Transport Abstraction (BSC 2005 [DIRS 173433], Section 8.1) is used to quantify the release of radionuclides from the EBS to the UZ. Dripping flux comprises a major source of liquid flow into the EBS. Condensation represents one source of dripping flux into the radionuclide transport model (BSC 2005 [DIRS 173433], Section 8.1). 
The EBS flow model is implemented directly in the TSPA-LA, as discussed in Section 8.1 of EBS Radionuclide Transport Abstraction (BSC 2005 [DIRS 173433]).

\section{Supporting Documents:}

BSC 2004 [DIRS 164327]

BSC 2005 [DIRS 173944]

\subsubsection{Flow Through Invert}

\section{FEP Number:}

2.1.08.05.0A

FEP Description: The invert, a porous material consisting of crushed tuff, separates the waste package from the bottom of the drift. Flow and transport through and around the invert can influence radionuclide release to the UZ.

\section{Screening Decision:}

Included

\section{Screening Argument: N/A}

TSPA Disposition: Flow within the EBS is addressed within several included FEPs as follows: Flow through the Invert (this FEP), Capillary Effects (Wicking) in EBS (FEP 2.1.08.06.0A in Section 6.2.38 of the current report), and Unsaturated Flow in the EBS (FEP 2.1.08.07.0A in Section 6.2.39 of the current report). Saturated Flow in the EBS (FEP 2.1.08.09.0A in Section 6.2 .40 of the current report) is excluded.

Hydraulic properties of EBS components and flow pathways within the EBS are discussed in detail in EBS Radionuclide Transport Abstraction (BSC 2005 [DIRS 173433], Section 6.3). The RTA model is used to quantify the time-dependent radionuclide releases from a failed waste package and their subsequent transport through the EBS to the emplacement drift wall/UZ interface. The basic inputs to the RTA model consist of the drift seepage influx, the environmental conditions in the drift (temperature, relative humidity, and water chemistry), and the degradation state of the EBS components (BSC 2005 [DIRS 173433], Section 6.1). Outputs consist of the rates of radionuclide releases to the $\mathrm{UZ}$ as a result of advective and diffusive transport, accounting for the impact of colloids, radionuclide solubility, retardation, and the degree of liquid saturation of the waste form and invert materials. The RTA model is implemented directly into the TSPA-LA GoldSim model to compute the radionuclide release rates from the EBS (BSC 2005 [DIRS 173433], Section 8).

The base case conceptual model for EBS flow is described in EBS Radionuclide Transport Abstraction (BSC 2005 [DIRS 173433], Section 6.3.1). The source of inflow to the EBS is the seepage flux that drips from the crown (roof) of the drift and imbibition flux from the UZ into the invert. This inflow can flow through the EBS along eight pathways: (1) seepage flux, (2) flux through the drip shield, (3) diversion around the drip shield, (4) flux through the waste package, (5) diversion around the waste package, (6) flux from the waste package into the invert, (7) imbibition flux from the UZ matrix to the invert, and (8) flux from the invert to the UZ 
fractures (BSC 2005 [DIRS 173433], Section 6.3.1.1 and Figure 6.3-1). These pathways are time- and location-dependent, because drip shield penetrations and waste package penetrations will vary with time and local conditions in the repository.

The conceptual model for flow through the EBS also includes three domains: the waste form (e.g., fuel rods or defense high-level radioactive waste (DHLW) glass), waste package corrosion products, and the invert. Because the pallet is not considered with respect to the transport of radionuclides through the EBS, water and radionuclides pass directly from the waste package to the invert.

The EBS flow abstraction, which is a component of the RTA model (BSC 2005 [DIRS 173433], Section 6.3.1), explicitly includes invert flows in the net flow of water from the EBS and the advective transport of radionuclides. Flow through the invert consists of the flux diverted by the drip shield and waste package and the flux through the waste package, and is reduced by any evaporation from the invert. Each of these terms is accounted for in the EBS flow abstraction, which is used directly in TSPA-LA.

Water saturation in the invert is an input to the RTA model and is provided by the MSTHM. The MSTHM determines the imbibition flux from the host rock matrix into the invert, as well as the water saturation in the invert (BSC 2005 [DIRS 173433], Section 6.3.3.4). Water saturation is used in calculating the diffusion coefficient both in the waste package and in the invert, and so it impacts radionuclide transport in the EBS. The amount of water that flows into the EBS by capillary effects and the resulting water saturation are documented in Multiscale Thermohydrologic Model (BSC 2005 [DIRS 173944], Section 6.3.3).

Multiscale Thermohydrologic Model (BSC 2005 [DIRS 173944], Appendix XV) also calculates the matrix saturation of the invert based on the inputs described in Table 4.1-1 of that report. These inputs include the hydrologic properties of the invert. Unlike the RTA model, the MSTHM simulates the invert as a dual-permeability medium consisting of "matrix" and "fracture" flow. This calculation develops the retention and unsaturated flow properties of the invert using a non-dimensionalized van Genuchten retention relation. The treatment of the invert as a dual continuum for flow and a single continuum for transport is justified in EBS Radionuclide Transport Abstraction (BSC 2005 [DIRS 173433], Section 7.3.2). Invert matrix saturations are then used in that report (BSC 2005 [DIRS 173433], Section 6.6.5) for the calculation of radionuclide transport.

\section{Supporting Documents:}

BSC 2005 [DIRS 173944]

BSC 2005 [DIRS 173433]

\subsubsection{Capillary Effects (Wicking) in EBS}

\section{FEP Number:}

2.1.08.06.0A

FEP Description: Capillary rise, or wicking, is a potential mechanism for water to move through the waste and EBS. 


\section{Screening Decision:}

Included

\section{Screening Argument: N/A}

TSPA Disposition: Flow within the EBS is addressed within several included FEPs as follows: Capillary Effects (Wicking) in EBS (this FEP), Flow Through Invert (FEP 2.1.08.05.0A in Section 6.2.37 of the current report), and Unsaturated Flow in the EBS (FEP 2.1.08.07.0A in Section 6.2.39 of the current report). The other relevant inputs to this FEP include the hydrologic properties of the host rock at the repository horizon, as discussed in Multiscale Thermohydrologic Model (BSC 2005 [DIRS 173944], Section 6.1). Saturated Flow in the EBS (FEP 2.1.08.09.0A in Section 6.2.40 of the current report) is excluded.

Multiscale Thermohydrologic Model (BSC 2005 [DIRS 173944], Section 6.1) addresses the range of thermal-hydrologic conditions predicted in the repository emplacement drifts and the adjoining host rock for the repository at Yucca Mountain. The effect of capillary flux of water from the host rock to the invert is captured by the analysis described in that report (BSC 2005 [DIRS 173944], Section 6.3.3). Chemistry of the water wicked into the invert is predicted by Engineered Barrier System: Physical and Chemical Environment (BSC 2005 [DIRS 175083], Section 6.13.4). The methodology for predicting chemical evolution of these waters for cases where influx could originate from the base of the drift is discussed in Section 6.6 of that report (BSC 2005 [DIRS 175083]).

The invert matrix saturations provided by the MSTHM are used in calculating radionuclide transport through the invert as well as water chemistry within the invert. Invert matrix saturations are passed on to EBS Radionuclide Transport Abstraction (BSC 2005 [DIRS 173433], Section 6.5.3.3), where the flow and transport in and around the invert is calculated and coded for implementation in the TSPA-LA. EBS Radionuclide Transport Abstraction (BSC 2005 [DIRS 173433]) also addresses additional mechanisms (via advection and diffusion) for water to move through the EBS and waste (BSC 2005 [DIRS 173433], Section 8.1). Hydraulic properties of EBS components and flow pathways within the EBS are discussed in detail in that report.

Wicking is not modeled as a flow mechanism in EBS Radionuclide Transport Abstraction (BSC 2005 [DIRS 173433]). However, the abstraction does account for the mass of water brought into the invert because of wicking through the invert water saturation term (BSC 2005 [DIRS 173433], Section 6.5.3.3). Water saturation is used in calculating the diffusion coefficient both in the waste package and in the invert, and so it affects radionuclide transport in the EBS (BSC 2005 [DIRS 173433], Section 6.3.4). Particularly in the case of no seepage flux, wicking draws water into the invert from the drift walls, providing a pathway for diffusive transport.

\section{Supporting Documents:}

BSC 2005 [DIRS 173944]

BSC 2005 [DIRS 173433] 


\subsubsection{Unsaturated Flow in the EBS}

FEP Number:

2.1.08.07.0A

FEP Description: Unsaturated flow may occur along preferential pathways in the waste and EBS. Physical and chemical properties of the EBS and waste form, in both intact and degraded states, should be considered in evaluating pathways.

\section{Screening Decision:}

Included

\section{Screening Argument: N/A}

TSPA Disposition: Flow within the EBS is addressed within several included FEPs as follows: Capillary Effects (Wicking) in EBS (FEP 2.1.08.06.0A in Section 6.2.38 of the current report), Flow through Invert (FEP 2.1.08.05.0A in Section 6.2.37 of the current report), and Unsaturated Flow in the EBS (this FEP). Saturated Flow in the EBS (FEP 2.1.08.09.0A in Section 6.2.40 of the current report) is excluded.

Flow in the EBS is described in EBS Radionuclide Transport Abstraction (BSC 2005 [DIRS 173433], Sections 6.3 and 6.5), which provides such input directly to the TSPA-LA. Hydraulic properties of EBS components and flow pathways within the EBS are discussed in detail in that report. The base case conceptual model for EBS flow is described in Section 6.3.1 of EBS Radionuclide Transport Abstraction (BSC 2005 [DIRS 173433]). The source of inflow to the EBS is the seepage flux that drips from the crown (roof) of the drift and imbibition flux from the UZ into the invert. This inflow can flow through the EBS along eight pathways: (1) seepage flux, (2) flux through the drip shield, (3) diversion around the drip shield, (4) flux through the waste package, (5) diversion around the waste package, (6) flux from the waste package into the invert, (7) imbibition flux from the UZ matrix to the invert, and (8) flux from the invert to the UZ fractures (BSC 2005 [DIRS 173433], Section 6.3.1.1 and Figure 6.3-1). These pathways are time- and location-dependent, in the sense that drip shield gaps, drip shield penetrations, and waste package penetrations will vary with time and local conditions in the repository.

The conceptual model for flow through the EBS also includes three domains: the waste form (e.g., fuel rods or DHLW glass), waste package corrosion products, and the invert. Because the presence of the emplacement pallet is ignored, water and radionuclides pass directly from the waste package to the invert.

Because the repository is located above the water table, water movement in the EBS is conceptualized as flow under varying degrees of saturation; the flow pathways are modeled as described above (BSC 2005 [DIRS 173433], Section 6.3.1 and Table 6.3-1). Flow pathways that include the waste package and drip shield are modeled as quasi-steady state flows without regard to the detailed mechanisms of the flow (BSC 2005 [DIRS 173433], Sections 6.3.3.2 and 6.3.2.4, respectively). The calculated transport of radionuclides is bounded by variation of the flux uncertainty term in the case of nonzero seepage flux (BSC 2005 [DIRS 173433], 
Section 6.3.3.2). Under no-seep conditions, where advective transport does not occur, saturation in the waste package is calculated in the RTA model, which impacts transport from the EBS (BSC 2005 [DIRS 173433], Section 6.5.3.2, Step 2). A modification of the diffusion coefficient for the effect of saturation is also developed in the RTA model (BSC 2005 [DIRS 173433], Section 6.3.4.1). The modification shows that the diffusion coefficient is enhanced by large saturation values. Thus, for fully saturated conditions (i.e., a saturation value of one) the effect of saturation on the diffusion coefficient is the highest.

As discussed in Engineered Barrier System: Physical and Chemical Environment (BSC 2005 [DIRS 175083], Section 1), the in-drift chemistry is predicted, depending upon the scenario, as a function of incoming seepage water, and the local conditions of temperature, relative humidity, and in-drift partial pressure of carbon dioxide. The chemical composition of water entering the drift by wicking in the invert or by crown seepage is predicted by the process described in Section 6.6 of that report. The required seepage water composition inputs for in-drift chemistry modeling were abstracted from model outputs of time-dependent seepage water compositions and gas-phase compositions in the host rock (near-field environment) adjacent to the drift wall. A discussion of the model used to derive these compositions is presented in Drift-Scale THC Seepage Model (BSC 2005 [DIRS 172862], Sections 6.2 and 6.4).

Flows in the invert are influenced by predictions presented in Multiscale Thermohydrologic Model (BSC 2005 [DIRS 173944], Section 6.3.3), which explicitly accounts for the degree of water saturation in the invert. The MSTHM determines the imbibition flux from the host rock matrix into the invert, as well as the water saturation in the invert for use in the RTA model (BSC 2005 [DIRS 173433], Section 6.3.3.4). Water saturation in the invert is an input to the RTA model and is provided by the MSTHM. Water saturation is used in calculating the diffusion coefficient both in the waste package and in the invert, and so it impacts radionuclide transport in the EBS. Particularly in the case of no seepage flux, wicking draws water into the invert from the drift walls, providing a pathway for diffusive transport. The amount of water that flows into the EBS by capillary effects and the resulting water saturation are documented in Multiscale Thermohydrologic Model (BSC 2005 [DIRS 173944], Section 6.3.3).

Effects of Drip Shield on Flow (FEP 2.1.06.06.0A in Section 6.2.25 of the current report), Mechanical Degradation of Emplacement Pallet (FEP 2.1.06.05.0A in Section 6.2.21 of the current report), and Flow Through Invert (FEP 2.1.08.05.0A in Section 6.2.37 of the current report) all address aspects of flow in the EBS.

\section{Supporting Documents:}

BSC 2005 [DIRS 173433]

BSC 2005 [DIRS 175083]

\subsubsection{Saturated Flow in the EBS}

\section{FEP Number:}

2.1.08.09.0A 
FEP Description: Saturated flow and radionuclide transport may occur along preferential pathways in the waste and EBS. Physical and chemical properties of the EBS and waste form, in both intact and degraded states, should be considered in evaluating pathways.

\section{Screening Decision:}

Excluded (Low Consequence)

Screening Argument: The repository horizon lies well above (approximately $300 \mathrm{~m}$ ) the water table, as documented in D\&E/RIT IED Subsurface Facilities [Sheet 1 of 4] (BSC 2004 [DIRS 172801], Table 2, for repository elevation) and in Development of Numerical Grids for UZ Flow and Transport Modeling (BSC 2004 [DIRS 169855], Figure 6-2, for water table elevation). Flow within the EBS is addressed within several included FEPs as follows: Capillary Effects (Wicking) in EBS (FEP 2.1.08.06.0A), Flow through Invert (FEP 2.1.08.05.0A), and Unsaturated Flow in the EBS (FEP 2.1.08.07.0A).

Flow in the EBS, either saturated or unsaturated, is described in EBS Radionuclide Transport Abstraction (BSC 2005 [DIRS 173433], Sections 6.3 and 6.5). Hydraulic properties of EBS components and flow pathways within the EBS are discussed in detail in that report. The source of inflow to the EBS is the seepage flux that drips from the crown (roof) of the drift and imbibition flux from the UZ into the invert. This inflow can flow through the EBS along eight pathways: (1) seepage flux, (2) flux through the drip shield, (3) diversion around the drip shield, (4) flux through the waste package, (5) diversion around the waste package, (6) flux from the waste package into the invert, (7) imbibition flux from the UZ matrix to the invert, and (8) flux from the invert to the UZ fractures (BSC 2005 [DIRS 173433], Section 6.3.1.1 and Figure 6.3-1). The conceptual model for flow through the EBS also includes three mixing domains: one for the waste form (e.g., fuel rods or high-level radioactive waste (HLW) glass), one for waste package corrosion products, and a third for the invert. Because the presence of the emplacement pallet is not considered with respect to the transport of radionuclides through the EBS, water and radionuclides pass directly from the waste package to the invert.

Because the repository is located above the water table, water movement in the EBS is conceptualized as flow under varying degrees of saturation (see FEP 2.1.08.07.0A in Section 6.2.39 of the current report); the flow pathways are modeled as described above (BSC 2005 [DIRS 173433], Section 6.3 and Figure 6.3-1).

While saturation may reach high values locally and perhaps temporarily, the presence of larger, persistent saturated flow pathways in the EBS is unlikely. As shown in the results of Multiscale Thermohydrologic Model (BSC 2005 [DIRS 173944], Section 6.3.3), saturations in the invert rarely achieve 1.0, and are generally less than 0.95 throughout the regulatory period. Nor is the invert a significant contributor to the barrier capability of the repository system (when compared to the UZ) due to its relatively short flow path length.

Localized saturated flow conditions in the EBS will therefore not have a significant effect on long-term repository performance. Omission of this FEP from the TSPA-LA does not influence the magnitude and time of the resulting radiological exposures to the RMEI or radionuclide releases to the accessible environment. 


\section{TSPA Disposition:}

N/A

\section{Supporting Documents: \\ $\mathrm{N} / \mathrm{A}$}

\subsubsection{Repository Resaturation Due to Waste Cooling}

\section{FEP Number:}

2.1.08.11.0A

FEP Description: Following the peak thermal period, water in the condensation cap may flow downward, resaturating the geosphere dry-out zone and flowing into the drifts. This may lead to an increase in water content and/or resaturation in the repository.

\section{Screening Decision:}

Included

\section{Screening Argument:}

N/A

TSPA Disposition: The thermal-hydrologic (TH) seepage model developed in Abstraction of Drift Seepage (BSC 2004 [DIRS 169131], Section 6.3.2) provides a detailed description of condensation reflux and its impact on thermal seepage. This abstraction is incorporated into TSPA along with thermal and hydrologic conditions provided by Multiscale Thermohydrologic Model (BSC 2005 [DIRS 173944]) to account for thermal effects on seepage (BSC 2004 [DIRS 169131], Section 6.5.2.1). The MSTHM includes a calculation of the postclosure thermohydrologic conditions, including dryout during the heating phase and rewetting during the cooling phase. Using the modeling methodology described in Multiscale Thermohydrologic Model (BSC 2005 [DIRS 173944], Section 6.2), the repository dryout is characterized by the MSTHM output variables of temperature and liquid-phase flux in the near field host rock. The resaturation of the dryout zone is captured by the TSPA-LA using the MSTHM output of relative humidity and invert saturations at waste package locations (BSC 2005 [DIRS 173944], Section 6.3.1).

The maximum lateral extent of the boiling zone (or zone of two-phase flow) relative to the centerline of the emplacement drifts provides a strong indication of the likelihood of continuous condensate and percolation-flux drainage around emplacement drifts. For the three infiltration-flux data sets considered in the multiscale thermohydrologic model, the maximum lateral extent of boiling ranges from 5.1 to $17.8 \mathrm{~m}$, with a median maximum lateral extent of $7.9 \mathrm{~m}$ (BSC 2005 [DIRS 173944], Table 6.3-8). It is important to note that the lateral extent of boiling is always much smaller than the half spacing between emplacement drifts (BSC 2005 [DIRS 173944], Section 6.3.1.1). Therefore, the majority of the host rock between the emplacement drifts always remains below the boiling point, thereby enabling condensate and percolation flux to continuously drain between emplacement drifts. The condensate that exists above the drifts does not reflux sufficiently to augment liquid-phase saturation during the post-boiling rewetting period as discussed in Drift Scale Coupled Process (DST and TH Seepage) Models (BSC 2005 [DIRS 172232], Section 6.2.4). Therefore, the return flow of reflux 
from the condensate zone to the dryout zone does not cause the seepage into the drifts to be greater than that which would occur under ambient (unheated) conditions.

The chemistry of the condensate waters in the host rock above the repository drifts is determined as discussed in Drift-Scale THC Seepage Model (BSC 2005 [DIRS 172862], Section 6.2.2.1). The selection of the waters that could potentially enter the emplacement drifts is discussed in Post-Processing Analysis of THC Seepage (BSC 2004 [DIRS 169858], Section 6.2.3.3). A discussion of the TSPA implementation of the seepage rates of these waters is found in Abstraction of Drift Seepage (BSC 2004 [DIRS 169131], Sections 6.7 and 6.7.1.2).

\section{Supporting Documents:}

BSC 2005 [DIRS 173944]

\subsubsection{Induced Hydrologic Changes in Invert}

\section{FEP Number:}

2.1.08.12.0A

FEP Description: Drainage in the drifts may be altered by plugging of fractures or floor buckling. Possible effects include wetting or ponding in the invert until the water level reaches the fractures in the wall or until there is sufficient hydraulic head to clear the fractures. Wetting or ponding could provide a continuing source of water vapor for interaction with the drip shields, waste packages, and their supports.

\section{Screening Decision:}

Excluded (Low Consequence)

Screening Argument: The repository horizon lies well above (approximately $300 \mathrm{~m}$ ) the water table, as documented in D\&E/RIT IED Subsurface Facilities [Sheet 1 of 4] (BSC 2004 [DIRS 172801], Table 2, for repository elevation) and in Development of Numerical Grids for UZ Flow and Transport Modeling (BSC 2004 [DIRS 169855], Figure 6-2, for water table elevation). The emplacement drifts will be configured as a series of tunnels in the mountain. As described in Multiscale Thermohydrologic Model (BSC 2005 [DIRS 173944], Section 6.3.9), the repository lies within four host-rock units (Tptpul, Tptpmn, Tptpll, and Tptpln). For the range of hydrologic properties of the four host-rock units, fracture permeability is sufficiently large and fractures are sufficiently well-connected to allow gravity-driven drainage of percolation to occur in an unrestricted fashion, thus preventing wetting and ponding in the invert. As described in In-Drift Natural Convection and Condensation (BSC 2004 [DIRS 164327], Section 8.3.1.1), condensate on the drift wall will tend to be imbibed into the host rock, away from the drift opening. Condensate that does not imbibe runs down the drift walls. Condensate that runs down the drift walls can flow only to the edges of the invert where it is in contact with the host rock, and proceeds to drain away from the drift (BSC 2004 [DIRS 164327], Section 8.3.1.1).

It is conceivable that granular debris from tunnel-boring machine cuttings created during excavation could accumulate in fractures in the floor and inhibit drainage in localized areas. To preclude "wetting or ponding" as described in this FEP, the repository is designed with horizontal emplacement drifts. Subsurface Facility Description Document (BSC 2005 [DIRS 174514], Section 4.1.1.2) specifies the emplacement drifts design: 
...with a zero percent gradient to limit horizontal migration of water within the drift. The adjacent turnout drift openings are designed with a gradient away from the emplacement drift and toward the access main, to prevent water draining into the drift. The inverts of the adjacent exhaust mains are at lower elevations than the invert of the emplacement drifts to prevent water drainage into the drift.

Section 6.2.32 of the current report (FEP 2.1.11.10.0A) corroborates this argument as floor displacements due to stress buildup are determined to be negligible relative to creating conditions that support ponding.

Thus, the repository emplacement drift design will preclude wetting or ponding along the invert-rock interface. Saturation buildup in the invert, if it occurs, will form at the bottom and spread up the curved surface, accessing additional fractures for drainage. Spreading of saturation axially down the drift will also access additional fractures. In this manner, localized seepage or condensation can readily drain downward into the host rock. Spreading of the flow will decrease the maximum flux and thereby reduce the potential for rapid transport of released radionuclides.

In summary, hydrologic changes in the invert that cause local wetting or ponding will be minor, and their exclusion from the TSPA-LA does not have a significant effect on the magnitude and time of the resulting radiological exposures to the RMEI or radionuclide releases to the accessible environment.

TSPA Disposition:

N/A

Supporting Documents:

$\mathrm{N} / \mathrm{A}$

\subsubsection{Condensation on Underside of Drip Shield}

\section{FEP Number:}

2.1.08.14.0A

FEP Description: Condensation of water on the underside of the drip shield may affect the waste package hydrologic and chemical environment.

\section{Screening Decision:}

Excluded (Low Consequence)

Screening Argument: In-Drift Natural Convection and Condensation (BSC 2004 [DIRS 164327], Section 8.3) predicts condensation rates within the EBS. Condensation rates are predicted using bounding cases that address vapor transport, mixing of gas under the drip shield, and availability of moisture in the invert.

Drift-wall condensation represents the condensation that could form on the walls of the drifts (BSC 2004 [DIRS 164327], Section 6.3.1) and is discussed in Section 6.2.35 of the present report under FEP 2.1.08.04.0A. Condensation on the underside of the drip shield may occur as shown by bounding analysis (BSC 2004 [DIRS 164327], Sections 6.3.7.2.3 and 6.3.7.2.4). 
However, as described below, analysis of the amount of such condensation and the nature of its possible effects leads to a conclusion that such condensation will have limited occurrence and intensity, and that the overall effect on dose will be small. This screening argument addresses the following components:

- Conditions necessary for condensation to occur

- Predicted conditions that bound the amount of condensation

- Effect of condensation on seismically induced waste package breach

- Effect of condensation on flux through the invert

- Effect of condensation on corrosion of the drip shield

- Effect of dripping of condensation onto a waste package.

Condensation under the drip shield (where dripping might occur onto, or into, the waste package) requires that water evaporated from the invert creates a partial pressure equal to or greater than the saturated vapor pressure at the temperature of the drip shield or the waste package. This does not happen unless the invert temperature is greater than the temperature of the upper half of the drip shield (other conditions also apply as discussed below). The above condition actually overstates the likelihood of condensation because the partial pressure of water vapor in the invert is decreased, relative to the saturation vapor pressure at the invert temperature, due to capillary vapor pressure lowering. Accordingly, because the invert temperature is always within a few degrees (higher or lower) of that of the overlying drip shield, the occurrence of condensation requires very moist conditions in the invert, otherwise the partial pressure of water vapor under the drip shield is too small. The fact that the temperatures of the crown of the drip shield and the top of the invert beneath the drip shield are always within a few degrees is calculated in Multiscale Thermohydrologic Model (BSC 2005 [DIRS 173944], Table 6.3-45). This calculated result regarding the relative temperatures of the drip shield and invert is also corroborated by experimental data from a $44 \%$-scale natural convection test of the in-drift configuration (BSC 2004 [DIRS 164327], Tables 7.4.1-23 and 7.4.1-24)

Results from In-Drift Natural Convection and Condensation (BSC 2004 [DIRS 164327], Sections 6.3.3.2.1 and 8) show that condensation under any drip shield does not occur when the water vapor partial pressure is controlled by the temperature at the bottom of the invert, which is always cooler than the top. Calculations in Multiscale Thermohydrologic Model (BSC 2005 [DIRS 173944], Section 6.3.11 and Table 6.3-45) show that for any given cross-section, the coolest and most humid location is always at the bottom of the invert. Therefore, water vapor that is transported longitudinally along the drift axis will have a greater tendency to condense at the bottom of the invert, where it is coolest and most humid. This occurs because the invert is permeable to gas movement and a poor conductor of heat, so the bottom is cooler.

Experimental results reported in In-Drift Natural Convection and Condensation (BSC 2004 [DIRS 164327], Table 7.4.1-24) show that the drip shield sides are cooler than the top, because of proximity to the waste package surface and natural convection. Therefore, condensation occurs preferentially on the sides where it cannot contact the waste package. The condensation model is a network model that represents the average drip shield temperature, and does not distinguish the top and sides (BSC 2004 [DIRS 164327], Section 6.3.5.1.3). 
The condensation model represents the water vapor partial pressure, and the associated evaporation rate, at the top of the invert using a bounding approximation (BSC 2004 [DIRS 164327], Section 6.3.7.2). This bounding condition of high invert transport and an unventilated drip shield does not exist unless there is sufficient seepage or drift-wall condensation, to wet up the invert under the drip shield, enough to support condensation on the underside of the drip shield. The condensation model shows that at 1,000 years for the nominal case, the condensation rate under the drip shield over a high-level waste (HLW) package is approximately $76 \mathrm{~kg} / \mathrm{yr}$ (BSC 2004 [DIRS 164327], Figure I.2-3, at a percolation rate of $20 \mathrm{~mm} / \mathrm{yr}$ ) for the high invert transport, low dispersion coefficient case. A HLW package was considered because it produces the smallest amount of decay heat and has the lowest temperature. At these same bounding conditions, the drift wall condensation rate is approximately $7 \pm 3 \mathrm{~kg} / \mathrm{m} / \mathrm{yr}$ (BSC 2004 [DIRS 164327], Figure H.2-1). Using a minimum waste package length of $3.45 \mathrm{~m}$, as given in IED Waste Package Configuration [Sheet 1 of 1] (BSC 2005 [DIRS 173501]), the drift wall condensation rate is approximately $24 \pm 10 \mathrm{~kg} / \mathrm{yr}$ (i.e., $7 \pm 3 \mathrm{~kg} / \mathrm{m} / \mathrm{yr} \times 3.45 \mathrm{~m}=24 \pm 10 \mathrm{~kg} / \mathrm{yr}$ ). At 10,000 years for the nominal case, the condensation model shows that the condensation rate under the drip shield is approximately $70 \mathrm{~kg} / \mathrm{yr}$ for the high invert transport, low dispersion coefficient case (BSC 2004 [DIRS 164327], Figure I.2-7, at a percolation rate of $20 \mathrm{~mm} / \mathrm{yr}$ ). The corresponding drift wall condensation rate is approximately $5 \mathrm{~kg} / \mathrm{m} / \mathrm{yr}$ (BSC 2004 [DIRS 164327], Figure H.2-5), which is approximately $17 \mathrm{~kg} / \mathrm{yr}$ using a minimum waste package length of $3.45 \mathrm{~m}$ (BSC 2005 [DIRS 173501]). The drift wall condensation is shown to be about two to six times less than the condensation rates predicted under the drip shield.

A test was conducted to corroborate predictions of condensation under the drip shield as discussed in Engineered Barrier System - Pilot Scale Test \#3, Heated Drip Shield Test Results (Howard et al. 2001 [DIRS 153282], Section 4.3). The test was a 1/4-scale heated experiment intended to evaluate a seeping environment within a simulated EBS that includes a simulated waste package, a drip shield, and an invert and substructure configured consistent with the emplacement drift design. Water was introduced through the top of the test cell and fell onto the drip shield. The water falling on the drip shield drained to the invert at the location where the drip shield legs contacted the invert. In this test, it was observed that the invert under the drip shield remained dryer than the environment outside the drip shield throughout the test. These observations support the assertion that boundary conditions for the condensation model are bounding with respect to the physical reality of the test. No condensation was seen under the drip shield, and the coolest temperatures on the drip shield were higher than the coolest parts of the invert (Howard et al. 2001 [DIRS 153282], Section 5).

In the repository, moisture from condensation under the drip shield could increase transport out of the waste package if it were to penetrate and dissolve or otherwise mobilize radionuclides for transport. Potential earthquake vibratory ground motion and the resulting interaction of the waste packages and the pallet may result in waste package damage due to both end-to-end impacts of adjacent waste packages and waste package to pallet impacts, as discussed in Seismic Consequence Abstraction (BSC 2005 [DIRS 173247], Section 6.5). It follows that the waste package breach location resulting from ground motion will occur at the waste package ends and at the waste package/pallet interface, or along the bottom of the waste package. In addition to the Alloy 22 outer corrosion barrier, the waste package contains a 50.8-mm-thick inner concentric cylinder composed of stainless steel (BSC 2005 [DIRS 173501]; BSC 2005 
[DIRS 174225], Section 4.1.1), providing additional structural stability and increasing the ability to limit the likelihood of water penetration. Therefore, the gravity flow of the drip shield condensation on the waste package will not penetrate such breaches, limiting advective transport of radionuclides from inside the waste package to the invert. It is recognized that condensation can run down to the underside of the waste package, but this water would need to move against gravitational force, at that point, to enter the waste package. So condensation under the drip shield will not increase the net quantity of radionuclides exiting a waste package damaged by a seismic event, even were it to drip or condense on the waste package outer barrier.

Implementation in the TSPA is discussed in EBS Radionuclide Transport Abstraction (BSC 2005 [DIRS 173433], Section 8.1), in which advective flux and diffusive transport from the waste package flows directly to the invert, ignoring the presence of the emplacement pallet. The gap between the waste package and the invert, which would inhibit diffusive transport to the invert, is not considered in the modeling approach in order to simplify estimates of diffusive transport through this pathway. The primary source of inflow to the EBS is the seepage flux that drips from the crown of the drift. The seepage flux includes any condensation that forms on the drift wall above the drip shield (BSC 2005 [DIRS 173433], Section 6.3.1.1). All of the water entering the drift in the RTA model flows into the invert and then enters the UZ. Thus, it follows that there is effectively no difference in the advective flux through the invert caused by condensation under the drip shield, which is modeled in TSPA.

The condensation model shows that condensation under a drip shield may occur if water vapor evaporated from the invert at one waste package location migrates under the connected drip shield segments for some distance and condenses on the underside of a cooler drip shield at another location (BSC 2004 [DIRS 164327], Section 6.3.7.2). This mode, however, is limited by the efficiency of axial water vapor migration compared with radial mixing. The condensation model results also show that with complete mixing of the gas under and above the drip shield (equalizing the partial pressure of water vapor) condensation does not occur on the underside of any drip shield. Engineered Barrier System-Pilot Scale Test \#3, Heated Drip Shield Test Results (Howard et al. 2001 [DIRS 153282], Section 5) reports that water vapor partial pressures are the same under and outside the drip shield. Under test condition, the water vapor partial pressures are approximately the same. This result suggests that the conditions required for condensation to form on the underside of the drip shield do not occur. Also, the condensation model shows that the radial thermal gradient is much greater than the axial thermal gradient (BSC 2004 [DIRS 164327], Figure 6.3.5-13 and Figure J-1, typically), and therefore radial mixing will be greater than axial mixing because thermal gradients drive mixing. Hence condensation under the drip shield is not expected to occur.

Condensation will not hasten corrosion of the drip shield. Condensate, which is composed of distilled water in equilibrium with the partial pressure of atmospheric carbon dioxide, will have a composition approximately equal to rain water. Rain water is described as a weak carbonic acid solution with a pH of approximately 5.6 (Stumm and Morgan 1996 [DIRS 125332], p. 161), depending upon the partial pressure of carbon dioxide in the atmosphere. The presence of liquid condensate on the waste package surface requires that the local temperature be at or below $96^{\circ} \mathrm{C}$. These conditions do not initiate localized corrosion of Alloy 22 or Titanium Grade 7, and are within the range of validation for implementation of the corrosion models in TSPA for general corrosion (BSC 2004 [DIRS 169984], Sections 8.1 and 6.4.3.4 (Equation 6-28 shows no 
chemistry dependence); BSC 2004 [DIRS 169845], Sections 8.3 and 6.9.1) and localized corrosion (BSC 2004 [DIRS 169984], Section 8.3; BSC 2004 [DIRS 169845], Section 8.4). Condensate mixed with dust is no more aggressive than the deliquescent dust without condensate. This is because the deliquescent solution will become more dilute due to the added water or come to equilibrium with the local relative humidity and partial pressure of carbon dioxide, a system essentially equivalent to dust deliquescence without condensate.

Dripping is only possible if water droplets form near the top of the drip shield; otherwise they run down the underside of the drip shield. If drops contact the waste package, they will tend to evaporate because the waste package is warmer, thus reducing the volume of liquid condensate available for advective transport of radionuclides. If drops contact a breached waste package, only those breaches on the top half of the waste package could support advective transport of liquid water into the waste package; those on the bottom half will not admit liquid water into the package. The geometrical relationship of dripping condensate with waste package breaches will limit the amount of advective flow through the breaches, in the manner described by the waste package flux-splitting algorithm (BSC 2005 [DIRS 173433], Section 6.3.3). If drops of condensate are advected into a waste package, they will tend to evaporate at warmer temperatures, reducing the volume of liquid available for advective transport of radionuclides. Conditions inside the breached waste package are likely to remain too dry for advective transport as long as the waste heat output greatly exceeds that necessary to evaporate the liquid inflow. After thermal output decays to ambient temperatures, there will not be a gradient driving water vapor into waste packages.

Based on the discussion above, condensation under the drip shield is excluded from TSPA-LA on the basis of low consequence because its exclusion will not have a significant effect on the magnitude and time of the resulting radiological exposures to the RMEI or radionuclide releases to the accessible environment.

TSPA Disposition:

N/A

Supporting Documents:

N/A

\subsubsection{Consolidation of EBS Components}

\section{FEP Number:}

2.1.08.15.0A

FEP Description: Physical and chemical degradation of the drip shield, invert, waste form, and waste package may cause collapse and settlement within the repository. This consolidation may affect the development of the chemical environment and, therefore, the radionuclide transport out of the EBS.

\section{Screening Decision:}

Excluded (Low Consequence) 
Screening Argument: Collapse and settlement of EBS components could impact long-term repository performance if degradation processes reduce these elements to essentially granular form. In this state (i.e., as particulate matter), the remnants of the EBS components could interact with water in the drift and thereby alter the chemical environment. However, as discussed below, analyses demonstrate that only minor degradation of EBS components is anticipated during the regulatory period.

Mechanical collapse of both the drip shield and waste package due to rockfall or drift collapse has been screened out (see FEPs 2.1.07.01.0A and 2.1.07.02.0A in Sections 6.2.28 and 6.2.29 of the current report). Thus, EBS consolidation due to waste package or drip shield failure, or both, can be excluded. The same holds for the invert. Degradation and consolidation of the invert have been screened out, as documented in Sections 6.2.22 and 6.2.24 of the current report under FEPs 2.1.06.05.0B and 2.1.06.05.0D. Thus, EBS consolidation due to invert, waste package and/or drip shield failure can be excluded.

The corrosion rates associated with the drip shield and waste package are very slow compared to the time-scale of interest, and these components will largely endure through the regulatory period. Conservative bounding analyses indicate that general corrosion would lead to a loss of about $2.6 \mathrm{~mm}$ of the Alloy 22 waste package outer barrier wall thickness and $0.75 \mathrm{~mm}$ of the drip shield wall thickness in 10,000 years, as discussed in IED Interlocking Drip Shield and Emplacement Pallet [Sheet 1 of 1] (BSC 2005 [DIRS 173303]), General Corrosion and Localized Corrosion of Waste Package Outer Barrier (BSC 2004 [DIRS 169984], Section 8.1), and in Aqueous Corrosion Rates for Waste Package Materials (BSC 2005 [DIRS 169982], p. 6-40). The nominal thickness of the drip shield is $15 \mathrm{~mm}$ (BSC 2005 [DIRS 173303], Table 5) and the thickness of the waste package outer barrier is $20 \mathrm{~mm}$ or $25.4 \mathrm{~mm}$ depending on the package type, as shown in IED Waste Package Configuration [Sheet 1 of 1] (BSC 2005 [DIRS 173501], Table 1).

Localized corrosion of the drip shield is not expected to occur under repository conditions as discussed in section 6.2.62 of the present report. Localized corrosion of the waste package is discussed in FEP 2.1.03.03.0A in Screening of Features, Events, and Processes in Drip Shield and Waste Package Degradation (BSC 2005 [DIRS 174995], Section 6.2.6, FEP 2.1.03.03.0A). As discussed in that analysis, localized corrosion of the waste package requires the presence of an aqueous phase on the waste package surface. Possible sources of such liquid are dust deliquescence and seepage. Localized corrosion from dust deliquescence on the waste package surface is excluded from TSPA as discussed in section 6.2.61 of the present report. Seepage water can contact the waste package only if the overlying drip shield has failed (BSC 2005 [DIRS 174995], Section 6.2.6, FEP 2.1.03.03.0A). An analysis of the type of drip shield failure required to allow seepage to contact the waste package is presented under FEP 1.2.02.03.0A in Section 6.2 .7 of the current report, which addresses processes specific to that FEP.

If the waste form degrades, its effects will remain confined to the interior of the waste package and have no wider impact. This is the basis for modeling in-package radionuclide transport as discussed in EBS Radionuclide Transport Abstraction (BSC 2005 [DIRS 173433], Section 6.3.4). Since collapse and extensive degradation of EBS components does not occur, any consolidation of these items will be of a minor nature. Therefore, consolidation of EBS components is screened out on the basis of low consequence. Omission of this FEP from 
TSPA-LA will not have a significant effect on the magnitude and time of the resulting radiological exposures to the RMEI or radionuclide releases to the accessible environment.

TSPA Disposition:

N/A

Supporting Documents:

N/A

\subsubsection{Chemical Characteristics of Water in Drifts}

FEP Number:

2.1.09.01.0A

FEP Description: When flow in the drifts is re-established following the peak thermal period, water may have chemical characteristics influenced by the near-field host rock and EBS. Specifically, the water chemistry ( $\mathrm{pH}$ and dissolved species in the groundwater) may be affected by interactions with cementitious materials or steel used in the disposal region. These point source contaminated waters may coalesce to form a larger volume of contaminated water. This altered groundwater is referred to as the carrier plume because dissolution and transport will occur in this altered chemical environment as contaminants move through the EBS, and down into the unsaturated zone. (Note: There is no defining limit as to what volume of contaminated water constitutes a plume.)

\section{Screening Decision:}

Included

\section{Screening Argument: N/A}

TSPA Disposition: The composition of water entering the drift by wicking in the invert or by crown seepage is used in Engineered Barrier System: Physical and Chemical Environment (BSC 2005 [DIRS 175083], Section 6.6). The required seepage water composition inputs for in-drift chemistry modeling were abstracted from thermal-hydrological-chemical model outputs of time-dependent seepage water compositions and gas-phase compositions in the host rock (near-field environment) adjacent to the drift wall. A discussion of the model used to derive these compositions is presented in Drift-Scale THC Seepage Model (BSC 2005 [DIRS 172862], Sections 6.2 and 6.4). The thermal-hydrological-chemical (THC) seepage model is based on a specific design basis thermal load and thermal decay rate, which are a function of repository loading and ventilation (BSC 2005 [DIRS 172862], Section 4.1.7).

Five different waters were selected to represent the spread of measured pore water data that serve as possible starting water compositions for the drift-scale THC seepage model. The rationale for the selection of these five waters is discussed in Section 6.2.2.1 of Drift-Scale THC Seepage Model (BSC 2005 [DIRS 172862]). A time-history of potential seepage water compositions is calculated with the THC model for each of the five starting pore waters, representing, at any given time interval, the closest occurrence to the drift of liquid water in the host rock. The THC model output is then abstracted to a subset of 368 water compositions representing the chemical 
evolution of the five starting waters as a function of location (the invert and the crown) through time. The selection of these waters is documented in Post-Processing Analysis of THC Seepage (BSC 2004 [DIRS 169858], Section 6.2.3.3), and in Engineered Barrier System: Physical and Chemical Environment (BSC 2005 [DIRS 175083], Section 6.6).

The subset of 368 water compositions from the THC seepage model gives equal probability to the five starting pore water compositions, and serves to provide seepage water inputs for in-drift chemistry modeling. The method used to group these waters into fewer representative units was to simulate evaporation of these potential seepage waters and is based on a model developed in In-Drift Precipitates/Salts Model (BSC 2004 [DIRS 169863]). The in-drift precipitates/salts (IDPS) model is a geochemical model designed to predict the postclosure effects of evaporation and deliquescence on the chemical composition of water within the EBS in support of the TSPA-LA (BSC 2004 [DIRS 169863], Section 1).

As documented in Engineered Barrier System: Physical and Chemical Environment (BSC 2005 [DIRS 175083], Section 6.6), these waters were grouped into 11 bins, according to a "normalized" chemistry determined by using geochemical modeling (EQ3/6) to simulate evaporation of the waters to a fixed activity of water. A representative water composition for each bin was chosen using a ranking algorithm. The representative bin waters were mapped back to the seepage water evolution histories for each of the five starting waters to create "bin history maps." Lookup tables were then created for each of the representative bin waters by simulating evaporation of the waters under a range of temperature and partial pressures of $\mathrm{CO}_{2}$ to produce a suite of possible in-drift water compositions (BSC 2005 [DIRS 175083], Section 6.9). These lookup tables are used to determine an incoming crown and invert water composition for performance assessment by randomly choosing one of the five starting waters and using the appropriate bin history map to determine the applicable bin. The predicted temperature and partial pressure of $\mathrm{CO}_{2}$ in the drift is then used to determine the appropriate lookup table for that bin water, and the water composition is determined as a function of predicted relative humidity in the drift (BSC 2005 [DIRS 175083], Sections 6.6 and 6.13).

Parameters extracted from the water chemistries and used by TSPA are $\mathrm{pH}$, ionic strength, and $\mathrm{Cl}^{-}$and $\mathrm{NO}_{3}{ }^{-}$concentrations. Input seepage compositions will be altered from the initial compositions due to evaporation from high initial temperatures and by reaction with rock minerals and mineral residues in pores and fractures left from the initial thermal event. The chemical system is described in Drift-Scale THC Seepage Model (BSC 2005 [DIRS 172862], Section 6.2.2.2).

Cementitious materials will be used in the turnouts, main access drifts, and exhaust main. The potential effects of cementitious materials on water chemistry and repository hydrology are described under FEP 2.1.06.01.0A in Section 6.2.18 of the current report.

Related FEPs are presented under FEP 2.1.09.17.0A in Waste-Form Features, Events, and Processes (BSC 2004 [DIRS 170020], Section 6.2.28), and under FEP 2.2.01.01.0B in Features, Events, and Processes in UZ Flow and Transport (BSC 2005 [DIRS 174191], Section 6.9.2).

Leaching of cementitious materials used in the turnouts in the main access and exhaust drifts could modify the composition of seepage water from the surrounding rock immediately below 
the main turnoff intersection footprints. This will occur sufficiently far from emplacement drifts that repository performance will not be affected.

Chemical Interaction with Corrosion Products in-drift are discussed in Section 6.2.46 of the current report under FEP 2.1.09.02.0A. Sorption in the EBS is described in Section 6.2.48 under FEP 2.1.09.05.0A.

Supporting Documents:

BSC 2005 [DIRS 175083]

BSC 2004 [DIRS 169863]

\subsubsection{Chemical Interaction with Corrosion Products}

\section{FEP Number:}

2.1.09.02.0A

FEP Description: Corrosion products produced during degradation of the waste form, metallic portions of the waste package, and metals in the drift (i.e., rock bolts, steel in the invert, gantry rails) may affect the mobilization and transport of radionuclides. Corrosion products may facilitate sorption/desorption and co-precipitation/dissolution processes. Corrosion products may form a "rind" around the fuel that could (1) restrict the availability of water for dissolution of radionuclides or (2) inhibit advective or diffusive transport of water and radionuclides from the waste form to the EBS. Corrosion products also have the potential to retard the transport of radionuclides to the EBS. Finally, corrosion products may alter the local chemistry, possibly enhancing dissolution rates for specific waste forms, or altering radionuclide solubility.

\section{Screening Decision:}

Included

\section{Screening Argument: N/A}

TSPA Disposition: FEP 2.1.09.02.0A, Chemical Interaction with Corrosion Products, is shared with Waste-Form Features, Events, and Processes (BSC 2004 [DIRS 170020], Section 6.2.20). The effects of corrosion product formation on in-drift water chemistry and gas composition are evaluated in Engineered Barrier System: Physical and Chemical Environment (BSC 2005 [DIRS 175083], Sections 6.8 and 6.7, respectively). The report includes effects of corrosion products on in-drift water chemistry and gas composition as part of the modeled chemical processes. In addition, the report accounts for corrosion in its oxygen mass balance analysis, where in-drift gas composition calculations are used to evaluate oxygen consumption due to corrosion of ground support materials and other committed materials (BSC 2005 [DIRS 175083], Section 6.7). In the physical and chemical environment model, thermal-hydrological-chemical seepage model abstracted water compositions are reacted with the Stainless Steel Type 316L ground support at the drift wall (BSC 2005 [DIRS 175083], Section 6.8).

The effect of corrosion products on the transport of radionuclides internal to the waste package is included in the TSPA-LA model and documented in EBS Radionuclide Transport Abstraction (BSC 2005 [DIRS 173433], Section 6.3.1). As discussed in Section 6.3.4.2 of that report 
(BSC 2005 [DIRS 173433]), retardation of radionuclides occurs in the waste package corrosion products by application of sorption coefficients in corrosion products. Radionuclides leaving the waste package are modeled as directly entering the invert, where they are then exposed to the flow mechanisms of the UZ (BSC 2005 [DIRS 173433], Section 6.3.1.2). Inadequate sorption capacity in the corrosion products internal to the waste packages could lead to competition between radionuclides for sorption sites. A calculation performed in the RTA model shows that the mass of corrosion products is capable of sorbing all of the available radionuclide inventory (BSC 2005 [DIRS 173433], Appendix B).

Corrosion products also have an impact on the potential for colloid formation. This aspect of corrosion product impact is included as part of FEP 2.1.09.17.0A in Waste-Form Features, Events, and Processes (BSC 2004 [DIRS 170020], Section 6.2.28).

\section{Supporting Documents:}

BSC 2005 [DIRS 175083]

BSC 2004 [DIRS 169991]

\subsubsection{Volume Increase of Corrosion Products Impacts Other EBS Components}

\section{FEP Number:}

2.1.09.03.0C

FEP Description: Corrosion products have a higher molar volume than the intact, uncorroded material. This FEP addresses volume increase in all EBS components other than waste package, waste form, and cladding. Increases in volume during corrosion of steel in the invert may change the stress state or structural integrity of the invert.

\section{Screening Decision:}

Excluded (Low Consequence)

Screening Argument: This FEP represents one particular mechanism for inducing mechanical failure of the invert. Mechanical degradation of the invert is addressed in Section 6.2.22 of the current report under FEP 2.1.06.05.0B.

As discussed in Engineered Barrier System: Physical and Chemical Environment (BSC 2005 [DIRS 175083], Section 6.4.2, Figure 6.4-3), the carbon steel components in the invert are predicted to corrode relatively rapidly as compared to other in-drift committed materials, within a few hundred years.

Configuration of the invert steel structure is shown in D\&E / PA/C IED Emplacement Drift Configuration and Environment (BSC 2004 [DIRS 168489]). The ability of carbon steel mechanical supports, which comprise the invert substructure, to induce mechanical loads by volume expansion will not be significant. As the steel invert structural components degrade, their total volume including the corrosion products will increase. As the volume of these materials increases, it can expand vertically without resistance into the drift, and this will create no increase in stresses in the support system. As can be seen from the planned drip shield configuration presented in Subsurface Facility Description Document (BSC 2005 [DIRS 174514], Section 4.1.1.3.6.1 and Figure 4-5), any volume expansion in the invert of the 
drip shield due to corrosion will impose no added stress because the drip shield is not rigidly mounted to the invert and move as a rigid body into the drift.

The corrosion products created by the degradation of the invert steel could enter the pore space of the invert ballast and alter its porosity. The potential for this change in porosity to alter radionuclide transport in the drift could be accounted for in the uncertainty in the parameter ranges selected for use in analyses of diffusion, as described in Radionuclide Transport Abstraction (BSC 2005 [DIRS 173433], Section 6.3.4.1.1). However, the uncertainty in the porosity estimates is enveloped by the uncertainty ranges of diffusion. Therefore, the effects of this change in porosity are not explicitly considered.

In summary, omission of potential corrosion products volume increase from the TSPA-LA will not have a significant effect on the magnitude and time of the resulting radiological exposures to the RMEI or radionuclide releases to the accessible environment.

TSPA Disposition:

N/A

Supporting Documents:

N/A

\subsubsection{Sorption of Dissolved Radionuclides in EBS}

\section{FEP Number:}

2.1.09.05.0A

FEP Description: Sorption of dissolved radionuclides within the waste package may affect the aqueous concentrations of radionuclides released to the EBS.

\section{Screening Decision:}

Included

\section{Screening Argument: \\ N/A}

TSPA Disposition: Sorption of dissolved radionuclides in the EBS is an important component of the RTA model. Sorption parameters (sorption coefficients and distribution coefficients) appropriate for sorption onto corrosion products inside the waste package, onto colloids (see FEP 2.1.09.19.0A in Section 6.2.53 of the current report), and onto crushed tuff in the invert are developed or summarized in EBS Radionuclide Transport Abstraction (BSC 2005 [DIRS 173433], Section 6.3.4.2.2.1). The sorption coefficients are uncertain parameters that are sampled in TSPA-LA. The RTA model, including sorption of dissolved radionuclides, is implemented directly in TSPA-LA and thus has a direct impact on estimated releases of radionuclides from the EBS.

The RTA model is used to quantify the time-dependent radionuclide releases from a failed waste package and their subsequent transport through the EBS to the emplacement drift wall/UZ interface (BSC 2005 [DIRS 173433], Section 6.3.4). The basic inputs to the RTA model consist 
of the drift seepage influx, the environmental conditions in the drift (temperature, relative humidity, and water chemistry) (BSC 2005 [DIRS 173433], Section 6.1), and the degradation state of the EBS components. Outputs consist of the rates of radionuclide releases to the UZ as a result of advective and diffusive transport, accounting for the impact of colloids, radionuclide solubility, retardation, and the degree of liquid saturation of the waste form and invert materials. The RTA model is implemented directly into TSPA-LA to compute the radionuclide release rates from the EBS.

The conceptual model for flow through the EBS also includes three domains: the waste form (e.g., fuel rods or DHLW glass), waste package corrosion products, and the invert. Because the presence of the emplacement pallet is ignored, water and radionuclides pass directly from the waste package to the invert.

Supporting Documents:

BSC 2005 [DIRS 173433]

\subsubsection{Reduction-Oxidation Potential in Drifts}

\section{FEP Number:}

2.1.09.06.0B

FEP Description: The redox potential in the EBS influences the oxidation of the in-drift materials and the in-drift solubility of radionuclide species. Local variations in the in-drift redox potential can occur.

\section{Screening Decision:}

Included

\section{Screening Argument:}

N/A

TSPA Disposition: Engineered Barrier System: Physical and Chemical Environment (BSC 2005 [DIRS 175083], Section 6.7) evaluates the reduction-oxidation (redox) potential in the EBS drifts as part of the modeled chemical processes. The report accounts for redox potential in its oxygen mass balance analysis (BSC 2005 [DIRS 175083], Section 6.7). Specifically, in-drift gas composition calculations evaluated oxygen composition due to corrosion of ground support materials and other committed materials. The estimate of oxygen flux begins with calculating the gas flux across the drift wall and into the drift (BSC 2005 [DIRS 175083], Section 6.7.1). Engineered Barrier System: Physical and Chemical Environment (BSC 2005 [DIRS 175083]) presents values of flux into (or out of) the drift at the crown, side, and bases of the drift at each time step. The analysis concludes that oxidizing conditions will persist in the in-drift environment well past the regulatory period. Thus, the effects of redox reactions are included.

In a study of corrosion environments relative to the degradation of Alloy 22, Pulverenti et al. (2002 [DIRS 165537]) used experimental procedures to evaluate shifts in acid/base conditions and consequent fluctuating reduction and oxidation environments. Here, hydrazine $\left(\mathrm{N}_{2} \mathrm{H}_{4}\right)$ was used to simulate reducing conditions in the experiments. These conditions will not exist in the 
repository. Engineered Barrier System: Physical and Chemical Environment (BSC 2005 [DIRS 175083], Section 6.7) indicates that the conditions of Yucca Mountain would be oxidizing. This would preclude the presence of hyrdazine since hydrazine decomposes to ammonia, hydrogen, and nitrogen gases in an oxidizing environment.

Any reducing conditions produced by the corrosion of materials in the EBS would be confined to a limited time during the thermal pulse, as shown in Engineered Barrier System: Physical and Chemical Environment (BSC 2005 [DIRS 175083], Section 6.7.1.2 and Figure 6.7-2), which presents the molar $\mathrm{O}_{2}$ and $\mathrm{CO}_{2}$ gas fluxes into the drift per year per linear meter of drift. The analysis shows an initial rapid increase in gas flux $\left(\mathrm{O}_{2}\right)$ during the thermal pulse, followed by a more sustained decrease that is due to water vapor displacing air outward from the drift for a few hundred years following closure. The potential for reducing conditions to occur in the drift is also addressed in In-Drift Precipitates/Salts Model (BSC 2004 [DIRS 169863], Sections 4.1.2 and 6.6.2.4). The IDPS model is only validated for oxidizing conditions. Oxidizing conditions prevail as long as the equilibrium fugacity of oxygen does not fall far below $10^{-9}$ bars (BSC 2004 [DIRS 169863], Section 4.1.2). The IDPS model lookup table output includes boundary values, abstraction output, and supplemental calculations (BSC 2004 [DIRS 169863], Section 6.6.3.5). Boundary values include temperature, the fugacities of carbon dioxide and oxygen, and the reaction progress.

Supporting Documents:

BSC 2005 [DIRS 175083]

BSC 2004 [DIRS 169863]

(Note that the FEP number used in the supporting analysis reports and model reports was 2.1.09.06.0A, but it was subsequently split into two FEPs: 2.1.09.06.0A and 2.1.09.06.0B.)

\subsubsection{Reaction Kinetics in Drifts}

\section{FEP Number:}

2.1.09.07.0B

FEP Description: Chemical reactions, such as radionuclide dissolution/precipitation reactions and reactions controlling the reduction-oxidation state, may not be at equilibrium in the drifts.

\section{Screening Decision:}

Included

\section{Screening Argument: N/A}

TSPA Disposition: The effects of reaction kinetics are implicitly included in each geochemical submodel developed in Engineered Barrier System: Physical and Chemical Environment (BSC 2005 [DIRS 175083], Section 6.5.3). In reaction path geochemical modeling calculations using an EQ3/6 equilibrium model of the water compositions resulting from seepage evaporation (BSC 2005 [DIRS 175083], Section 6.9), reaction kinetics are implicitly included through suppression of individual mineral phases. The method used to simulate evaporation of potential seepage waters is based on a model developed in In-Drift Precipitates/Salts Model (BSC 2004 
[DIRS 169863]). The IDPS model is a geochemical model designed to predict the postclosure effects of evaporation on the chemical composition of water within the EBS in support of the TSPA-LA (BSC 2004 [DIRS 169863], Section 1).

Individual mineral phases were suppressed if those phases are kinetically inhibited from forming under repository conditions. A list of minerals inhibited during the modeling, including justification for the decision to inhibit each mineral, is presented in Section 6.5 and Table 6.5-2 of Engineered Barrier System: Physical and Chemical Environment (BSC 2005 [DIRS 175083]). The choice of mineral suppressions directly affects the modeled evolution of the in-drift waters, and hence the water compositions that are passed to the TSPA-LA in the form of lookup tables.

In addition, the kinetics of corrosion of committed materials was examined with respect to its effect on in-drift water and atmosphere compositions. Seepage water interactions with rock bolts and Stainless Steel Type 316L retainer plate at the drift wall are found to be of low consequence (BSC 2005 [DIRS 175083], Section 6.8). A sensitivity analysis shows that increasing corrosion rates by an order of magnitude has no significant effect on in-drift water and atmospheric compositions (BSC 2005 [DIRS 175083], Section 6.12.4.1.3). Oxygen consumption due to corrosion of ground support materials and other committed materials is evaluated using in-drift gas composition calculations (BSC 2005 [DIRS 175083], Section 6.7). Although the repository may have oxygen-depleting conditions for a short period after closure (a few hundred years), primarily due to the corrosion of mild steel, there is no long-term effect on repository atmosphere. The effects of corrosion kinetics were evaluated by reducing the corrosion rates; this resulted in a somewhat longer period of oxygen depletion, but is still not significant relative to regulatory periods.

As stated above, the effects of reaction kinetics are implicitly included in the geochemical submodels developed in Engineered Barrier System: Physical and Chemical Environment (BSC 2005 [DIRS 175083]) through the selection of mineral species allowed to form. Thus, the effects are part of the chemical composition data tables used by TSPA.

\section{Supporting Documents:}

BSC 2005 [DIRS 175083]

BSC 2004 [DIRS 169863]

\subsubsection{Diffusion of Dissolved Radionuclides in EBS}

\section{FEP Number:}

2.1.09.08.0A

FEP Description: Radionuclide transport of dissolved radionuclides by diffusion, in response to chemical gradients, may occur within the EBS. Physical and chemical properties of the EBS and waste form, in both intact and degraded states, should be considered in evaluating diffusive transport.

\section{Screening Decision:}

Included 


\section{Screening Argument:}

N/A

TSPA Disposition: The model developed in EBS Radionuclide Transport Abstraction (BSC 2005 [DIRS 173433], Section 6.3.4) is used to quantify the time-dependent radionuclide releases from a failed waste package and their subsequent transport through the EBS to the emplacement drift wall/UZ interface. The basic inputs to the RTA model consist of the drift seepage influx, the environmental conditions in the drift (temperature, relative humidity, and water chemistry), and the degradation state of the EBS components (BSC 2005 [DIRS 173433], Section 6.1). Outputs consist of the rates of radionuclide releases to the UZ as a result of advective and diffusive transport, accounting for the impact of colloids, radionuclide solubility, retardation, and the degree of liquid saturation of the waste form and invert materials. The RTA model is implemented directly into the TSPA-LA GoldSim model to compute the radionuclide release rates from the EBS.

The source of inflow to the EBS is the seepage flux that drips from the crown (roof) of the drift and imbibition flux from the UZ into the invert. This inflow can flow through the EBS along eight pathways: (1) seepage flux, (2) flux through the drip shield, (3) diversion around the drip shield, (4) flux through the waste package, (5) diversion around the waste package, (6) flux from the waste package into the invert, (7) imbibition flux from the UZ matrix to the invert, and (8) flux from the invert to the UZ fractures (BSC 2005 [DIRS 173433], Section 6.3.1.1 and Figure 6.3-1). These pathways are time dependent, because drip shield penetrations and waste package penetrations will vary with time and local conditions in the repository.

The conceptual model for flow through the EBS includes three domains: the waste form (e.g., fuel rods or DHLW glass), waste package corrosion products, and the invert. Because the presence of the emplacement pallet is ignored, water and radionuclides pass directly from the waste package to the invert.

Diffusive transport of dissolved radionuclides in the EBS is a major component of the RTA model. The effects of saturation, temperature, porosity, and chemical environment on diffusion in the invert are discussed in EBS Radionuclide Transport Abstraction (BSC 2005 [DIRS 173433], Section 6.3.4.1). The effects of waste form properties and degradation state on diffusion in the waste package are modeled explicitly; diffusion from the waste form is dependent on the volume, surface area and thickness of the "rind" of degraded waste form, and the amount of corrosion products in the waste package determines both their saturation (and consequently, the diffusivity) and their sorptive capacity (BSC 2005 [DIRS 173433], Section 6.3.4). Note that the model of the waste form used in the abstraction model does not explicitly account for the cladding. Instead, its presence is implicit in the model of waste forms. Uncertainty in diffusive transport is incorporated via parameters for invert diffusion coefficient uncertainty, stainless steel and carbon steel corrosion rates, diffusive path length through corrosion products inside a waste package, and the specific surface area of $\mathrm{Fe}_{2} \mathrm{O}_{3}$ corrosion products (BSC 2005 [DIRS 173433], Section 6.3.4). These parameters are sampled in TSPA-LA, and the model for diffusive transport of radionuclides is implemented directly in TSPA-LA. 


\section{Supporting Documents:}

BSC 2005 [DIRS 173433]

\subsubsection{Advection of Dissolved Radionuclides in EBS}

\section{FEP Number:}

2.1.09.08.0B

FEP Description: Radionuclide transport of dissolved radionuclides by advection with the flowing groundwater may occur within the EBS. Physical and chemical properties of the EBS and waste form, in both intact and degraded states, should be considered in evaluating advective transport.

\section{Screening Decision:}

Included

\section{Screening Argument:}

N/A

TSPA Disposition: The model developed in EBS Radionuclide Transport Abstraction (BSC 2005 [DIRS 173433], Section 6.3.4) is used to quantify the time-dependent radionuclide releases from a failed waste package and their subsequent transport through the EBS to the emplacement drift wall/UZ interface. The basic inputs to the RTA model consist of the drift seepage influx, the environmental conditions in the drift (temperature, relative humidity, and water chemistry), and the degradation state of the EBS components (BSC 2005 [DIRS 173433], Section 6.1). Outputs consist of the rates of radionuclide releases to the UZ as a result of advective and diffusive transport, accounting for the impact of colloids, radionuclide solubility, retardation, and the degree of liquid saturation of the waste form and invert materials. The RTA model is implemented directly into the TSPA-LA GoldSim model to compute the radionuclide release rates from the EBS.

The source of inflow to the EBS is the seepage flux that drips from the crown (roof) of the drift and imbibition flux from the UZ into the invert. This inflow can flow through the EBS along eight pathways: (1) seepage flux, (2) flux through the drip shield, (3) diversion around the drip shield, (4) flux through the waste package, (5) diversion around the waste package, (6) flux from the waste package into the invert, (7) imbibition flux from the UZ matrix to the invert, and (8) flux from the invert to the UZ fractures (BSC 2005 [DIRS 173433], Section 6.3.1.1 and Figure 6.3-1). These pathways are time dependent, in the sense that drip shield gaps, drip shield penetrations, and waste package penetrations will vary with time and local conditions in the repository.

Radionuclide solubilities are specified in Dissolved Concentration Limits of Radioactive Elements (BSC 2005 [DIRS 174566] Sections 6.5 through 6.18) to provide radionuclide concentrations in each of the flow pathways in the RTA model, specifically in the waste form, cladding and waste package corrosion products. The seepage flux into a drift is also an input to the RTA model. The flux-splitting model determines the fraction of the seepage flux that flows through breaches in the drip shield and waste package. Fluxes that flow through the drip shield are again split between those that flow around the waste package and those that flow into the 
waste package. Fluxes that are diverted around the waste package and the drip shield flow into the invert. These fluxes will not contain radionuclides. The RTA model does not require or address details about the flow mechanisms or type of flow (such as film flow) that is occurring in the waste form. EBS Radionuclide Transport Abstraction (BSC 2005 [DIRS 173433], Assumption 5.5) states that a thin film of adsorbed water is assumed always to exist on the surfaces of internal waste package components and corrosion products. This water film is assumed to behave as bulk liquid insofar as allowing radionuclides to dissolve in and diffuse through it. This assumption is based on the fact that all surfaces exposed to water vapor will adsorb water. The amount of adsorbed water vapor depends principally on the nature of the sorbing material and the ambient relative humidity. The first layers of adsorbed water often do not contain ions from the sorbing solid (Lee 1994 [DIRS 154380], p. 73). This suggests that multiple water layers are needed in order for solid species (such as radionuclides) to dissolve and diffuse. Thus, it is conservative to assume that radionuclides will dissolve in and diffuse through the adsorbed water film regardless of its thickness.

Radionuclide transport is modeled with three domains (cells) (BSC 2005 [DIRS 173433], Section 6.3.1.1). These are: (1) Radionuclides dissolved from the waste form (e.g., fuel rods or DHLW glass) and cladding; (2) waste package-corrosion products (a subset of the waste package); and (3) the invert.

Radionuclides from corrosion products and in solution are transported to the invert via advection and diffusion; longitudinal and transverse dispersion are ignored. Radionuclides interact with the crushed tuff in the invert by adsorption processes.

The invert cell (Cell 3) is in intimate contact with the waste package and is $0.597 \mathrm{~m}$ in thickness (BSC 2005 [DIRS 173433], Section 6.3.1.1). This is the average thickness of the invert directly beneath the waste package. This value is appropriate because flow out of the waste package is primarily downward, centered over the thickest part of the invert. The presence of an emplacement pallet is ignored. Consequently, water and radionuclides pass directly from the waste package and cladding to the invert.

The radionuclide concentration leaving the invert to the UZ is modeled as well-mixed and calculated as input to the total flux into the invert from all locations (that is, the flux diverted around the drip shield and the waste package, and the flux leaving the waste package), and the radionuclide mass introduced to the invert from the waste packages (Cells 1 and 2) via advection and diffusion (BSC 2005 [DIRS 173433], Section 6.3.1.2).

Flow through the invert is discussed in Section 6.2.37 of the current report under FEP 2.1.08.05.0A.

\section{Supporting Documents:}

BSC 2005 [DIRS 173433] 


\subsubsection{Sorption of Colloids in EBS}

FEP Number:

2.1.09.19.0A

FEP Description: Interactions between radionuclide-bearing colloids and the waste and EBS may result in retardation of the colloids during transport by sorption mechanisms.

\section{Screening Decision:}

Excluded (Low Consequence)

Screening Argument: As discussed in Waste Form and In-Drift Colloids-Associated Radionuclide Concentrations: Abstraction and Summary (BSC 2005 [DIRS 174290], Section 6.5.2.1), the TSPA considers that colloids with embedded and sorbed radionuclides leave the failed waste package and enter the drift geochemical environment. The colloids exit in-package chemical conditions and enter the invert chemical conditions. In the repository it is likely that interactions between radionuclide-bearing colloids and the waste and EBS would result in some retardation of the colloid transport by sorption mechanisms. EBS Radionuclide Transport Abstraction (BSC 2005 [DIRS 173433], Section 6.3.4.4) does not consider sorption of colloids in the EBS in its analysis of radionuclide transport. This is a reasonable approach, because the flow path through the invert is short compared to that of the UZ.

Physical filtration and gravitational settling of colloids in the EBS are similar to colloid sorption in that these processes tend to retard colloid transport. In Waste Form and In-Drift Colloids-Associated Radionuclide Concentrations: Abstraction and Summary (BSC 2005 [DIRS 174290], Sections 6.3.1 and 7.2), physical filtration of colloids is not explicitly called out in the abstraction. Colloids that leave a failed waste package through the failure opening are not subsequently filtered out nor settled in the surrounding EBS material, including the invert. This assumption overestimates the potential consequences of colloid-facilitated transport of radionuclides and is considered bounding. The effect of sorption is similar to filtration and settling, as all three processes result in the immobilization of the colloids. Ignoring sorption in the waste package and invert is therefore consistent with neglecting filtration and settling in order to achieve a bounding estimate of the consequences of colloid-facilitated transport in the EBS.

Further discussion on filtration of colloids in the EBS may be found in Section 6.2 .55 of the current report under FEP 2.1.09.20.0A. In summary, the magnitude and time of the resulting radiological exposures to the RMEI or radionuclide releases to the accessible environment would not be significantly changed by the exclusion of FEP 2.1.09.19.0A.

TSPA Disposition:

N/A

Supporting Documents:

N/A 


\subsubsection{Advection of Colloids in EBS}

FEP Number:

2.1.09.19.0B

FEP Description: Transport of radionuclide-bearing colloids in the waste and EBS may occur by advection.

\section{Screening Decision:}

Included

\section{Screening Argument: \\ N/A}

TSPA Disposition: The model developed in EBS Radionuclide Transport Abstraction (BSC 2005 [DIRS 173433], Section 6.3.4) is used to quantify the time-dependent radionuclide releases from a failed waste package and their subsequent transport through the EBS to the emplacement drift wall/UZ interface (BSC 2005 [DIRS 173433]). The basic inputs to the RTA model consist of the drift seepage influx, the environmental conditions in the drift (temperature, relative humidity, and water chemistry), and the degradation state of the EBS components (BSC 2005 [DIRS 173433], Section 6.1). Outputs consist of the rates of radionuclide releases to the UZ as a result of advective and diffusive transport, accounting for the impact of colloids, radionuclide solubility, retardation, and the degree of liquid saturation of the waste form and invert materials. The RTA model is implemented directly into the TSPA-LA GoldSim model to compute the radionuclide release rates from the EBS.

The source of inflow to the EBS is the seepage flux that drips from the crown (roof) of the drift and imbibition flux from the UZ into the invert. This inflow can flow through the EBS along eight pathways: (1) seepage flux, (2) flux through the drip shield, (3) diversion around the drip shield, (4) flux through the waste package, (5) diversion around the waste package, (6) flux from the waste package into the invert, (7) imbibition flux from the UZ matrix to the invert, and (8) flux from the invert to the UZ fractures (BSC 2005 [DIRS 173433], Section 6.3.1.1 and Figure 6.3-1). These pathways are time dependent, because drip shield penetrations and waste package penetrations will vary with time and local conditions in the repository.

An algorithm referred to as the drip shield flux-splitting model is developed for calculating the fraction of flow diverted by the drip shield when breaches in the drip shield exist (BSC 2005 [DIRS 173433], Section 6.3.2). If no breaches exist, the drip shield is considered to be completely effective in diverting all seepage flux.

The conceptual model for flow through the EBS also includes three domains: the waste form (e.g., fuel rods or DHLW glass), waste package corrosion products, and the invert. Because the presence of the emplacement pallet is ignored, water and radionuclides pass directly from the waste package to the invert.

The total flux entering the invert is equal to: (1) the flux diverted around the drip shield, (2) the flux diverted around the waste package, and (3) the flux leaving the waste package. The concentration of radionuclide bearing colloids in the invert is determined by the mass of colloids 
entering the invert and the total flux that leaves the invert (both described above). Except for the evaporative fluxes, all fluxes that enter the invert leave the invert to the UZ.

As discussed in EBS Radionuclide Transport Abstraction (BSC 2005 [DIRS 173433], Section 6.3.4.4), advective transport of radionuclide-bearing colloids in the waste form and waste package corrosion products is determined in the EBS transport abstraction. There are three types of colloids transported in the EBS: (1) waste form colloids, (2) colloids due to corrosion products, and (3) seepage or groundwater colloids (BSC 2004 [DIRS 173433], Section 6.3.1.2). The waste form and corrosion colloids may have irreversibly attached (embedded) or reversibly attached (sorbed) radionuclides. A portion of the mass concentration of dissolved radionuclides released from the waste package is reversibly sorbed onto groundwater colloids at the boundary of the waste package and the invert. The formation, stability, and concentration of colloids are addressed in Waste Form and In-Drift Colloids-Associated Radionuclide Concentrations: Abstraction and Summary (BSC 2005 [DIRS 174290]). The concentration of colloids, specifically in the waste form, waste package corrosion products, and invert, together with the water flow rates in each of the flow paths, determines the rate of advective releases of colloids from the EBS. The flux-splitting model determines the fraction of the seepage flux that flows through breaches in the drip shield and waste package. EBS Radionuclide Transport Abstraction (BSC 2005 [DIRS 173433]) does not require or address details about the flow mechanisms or type of flow (such as film flow) occurring in the waste form.

Radionuclide-bearing colloids are transported through the invert via advection and diffusion. Colloids are transported advectively at approximately the same velocity as the liquid flux leaving the waste package (BSC 2005 [DIRS 173433], Section 6.3.4.4). Longitudinal and transverse dispersion of colloids is ignored because of the short travel distance through the EBS (BSC 2005 [DIRS 173433], Section 6.3.4.4).

Supporting Documents:

BSC 2005 [DIRS 174290]

BSC 2005 [DIRS 173433]

\subsubsection{Filtration of Colloids in EBS}

\section{FEP Number:}

2.1.09.20.0A

FEP Description: Filtration processes may affect transport of radionuclide-bearing colloids in the waste and EBS. Filtration includes physical and electrostatic processes in pores and fractures of natural and anthropogenic materials, such as concrete and the joints between invert segments.

\section{Screening Decision:}

Excluded (Low Consequence)

Screening Argument: Modeling of transport of colloids within the EBS (within the waste package and the invert) conservatively excludes consideration of colloid filtration, as discussed in Waste Form and In-Drift Colloids-Associated Radionuclide Concentrations: Abstraction and Summary (BSC 2005 [DIRS 174290], Section 7.2). Through the exclusion of this process in the TSPA-LA model, the rate of radionuclide transport from the EBS to the UZ is maximized. This 
is a reasonable approach, because the flow path through the invert is short compared to that of the UZ.

Colloid filtration as discussed here refers to the physical removal of colloids from a flow system by pore clogging, sieving, and straining. Filtration of colloids generally means the retention of colloids moving with the suspending fluid in pores, channels, and fracture apertures that are too small or dry to allow passage of the colloids.

The following logical argument is relevant to the discussion. Within the waste package, colloids may form within the DHLW glass at its outer surfaces (e.g., degraded DHLW glass). Colloids could be filtered within fractures in fuel pellets or trapped at the boundaries of disaggregating grains. Colloids forming within spent nuclear fuel rods whose cladding has been breached could be filtered at perforations in the cladding. Additionally, colloids formed and released from the DHLW glass could be filtered at perforations in the stainless steel HLW container. Colloids reaching the interior of the waste package (after escaping from fuel-rod cladding and HLW containers) could be filtered at perforations in the skin of the waste package. In the underlying invert material (crushed tuff), the colloids that do exit the waste package environment could be subjected to filtration in pores and channels that are too small or dry to allow further movement.

In the TSPA-LA model, the assumption is made that all stable colloids formed within the waste package (the calculated colloid source term) exit the package and enter the invert without filtration; these colloids will then move through the invert material without being subjected to filtration until they reach the underlying UZ.

This FEP is excluded on the basis of low consequence. Since filtration within the waste package and the invert will occur to some extent, the model approach of neglecting filtration overestimates the potential impact of colloid-facilitated transport of radionuclides in the TSPA-LA dose calculations and is considered bounding. In summary, the magnitude and time of the resulting radiological exposures to the RMEI or radionuclide releases to the accessible environment would not be significantly changed by the omission of the filtration phenomena and exclusion of FEP 2.1.09.20.0A.

TSPA Disposition:

N/A

Supporting Documents:

$\mathrm{N} / \mathrm{A}$

\subsubsection{Transport of Particles Larger Than Colloids in EBS}

\section{FEP Number:}

2.1.09.21.0A

FEP Description: Groundwater flow through the waste could remove radionuclide-bearing particles by a rinse mechanism. Particles of radionuclide-bearing material larger than colloids could be entrained in suspension and then be transported in water flowing through the waste and EBS. 


\section{Screening Decision:}

Excluded (Low Consequence)

Screening Argument: Colloids by definition have at least one dimension between $1 \mathrm{~nm}$ and $1 \mu \mathrm{m}$. Often, particularly in reporting of experimental results, the upper end of the colloid size range is $450 \mathrm{~nm}$ and the lower limit is $>2 \mathrm{~nm}$, due to conventional dimensions of laboratory equipment (primarily filters) (BSC 2005 [DIRS 174290], Section 6.3.1). To a large extent, the effectiveness of colloids at facilitating contaminant transport is due to their large surface area (relative to mass and volume) available for sorption (BSC 2005 [DIRS 174290], Section 6.3.3.1). In order for radionuclide-bearing colloids to affect repository performance, the colloids must be stable for the time frame of transport and must carry significant amounts of radionuclides. Transport times can range from days/months/years for transport out of a failed waste package under a large seep, to hundreds of thousands of years for retarded transport to the accessible environment. Thus, some relatively unstable colloids generated at the waste form may persist long enough to be transported out of the waste package, increasing the radionuclide release from the waste package, but likely would not travel a significant distance away from the repository. The more stable colloids, however, may remain suspended for years and travel a much greater distance (BSC 2005 [DIRS 174290], Section 6.3.2).

If particles larger than colloids do form during the degradation of waste and waste package materials, these particles are likely to sorb radionuclides following the same principles as radionuclide sorption onto colloids (BSC 2005 [DIRS 174290], Section 6.3.3.1). In terms of mobility, however, several differences exist between colloids and larger particles, making it unlikely that the larger particles could unfavorably affect performance. First, since they would not be in the form of a suspension, large particles would require significant flow velocities to entrain ("rinse") and transport the particles out of the waste package. These flow velocities would need to persist during any transport process along the flow path length to enable the particles to remain in suspension. Second, their large size makes them more susceptible to filtration. Third, the suspension is unstable when particles are too large to be supported by forces that support colloidal-size particles, such as Brownian (thermal) forces. Particles in the YMP system (e.g., iron oxyhydroxide corrosion products or actinide bearing colloidal products) will have densities significantly greater than water and are therefore subject to gravitational settling.

Colloid dispersions are important in the consideration of potential radionuclide transport from the repository due to the extremely large number of particles present in these dispersions. The large number of particles in colloid dispersions yields a large total surface area available for sorption processes (BSC 2005 [DIRS 174290], Section 6.3.3). In contrast, dispersions of the "large" particles considered here will not have the large particle number populations observed for colloid-size particles, and thus the total surface area available for radionuclide sorption will be less.

In summary, the effects of suspensions of particles larger than colloids in the EBS have been excluded from TSPA-LA on the basis of low consequence. Omission of the effects of suspensions of particles larger than colloids will not significantly change radiological exposures or radionuclide releases because the formation of suspensions in the near field and far field environments is likely to be localized. Furthermore, even if these suspensions form, it is likely 
that these "large" particles will settle by gravity within a small distance as flow conditions change, so that their transport by moving water will not be significant.

The omission of transport of particles larger than colloids in the EBS from the TSPA-LA will not have a significant effect on the magnitude and time of the resulting radiological exposures to the RMEI or radionuclide releases to the accessible environment.

TSPA Disposition:

N/A

Supporting Documents:

N/A

\subsubsection{Sorption of Colloids at Air-Water Interface}

\section{FEP Number:}

2.1.09.22.0A

FEP Description: Colloids may be sorbed irreversibly at the gas-water interface under partially saturated conditions.

\section{Screening Decision:}

Excluded (Low Consequence)

Screening Argument: Colloid sorption at the air-water interface may occur within the waste package and invert. Both hydrophilic and hydrophobic colloids may be sorbed irreversibly at the gas-water interface under partially saturated conditions (Wan and Wilson 1994 [DIRS 114430]). Colloid attachment to air-water interfaces commonly occurs in unsaturated environments and may limit mobile colloid generation and migration (Wan and Wilson 1994 [DIRS 114430]). This phenomenon is dependent on the interface surface area, electrostatic charge on the particles, and the salinity of the aqueous phase.

At low water saturations, air-water interfaces are extensive, and colloids migration is retarded, although colloids may still move through the adsorbed water films if adequately thick (McGraw 1996 [DIRS 108218]). At intermediate water saturations there is still an interconnected gas phase, but relative air-water interface areas are lower. The interface may act as a static sorbing surface, but estimating the geometry and surface area is complicated, more so under changing saturation state. At high water saturations the majority of the gas is present as small gas bubbles that may migrate, transporting sorbed colloids. However, a proportion of the bubbles may become trapped and will effectively immobilize sorbed colloids.

Models of colloid transport in partially saturated media have been developed in recent years, and it is evident that sorption onto the air-water interfaces in the waste package and invert will occur to some extent (Wan and Wilson 1994 [DIRS 114430]). Neglecting retention at the air-water interface in the EBS will overestimate the potential impact to radionuclide releases of colloid-facilitated transport of radionuclides; this approach is bounding. This is a reasonable approach because the flow path through the invert is short compared to that of the UZ. Sorption of colloids in the UZ below the repository is covered by FEP 2.2.08.09.0B in Features, Events, 
and Processes in UZ Flow and Transport (BSC 2005 [DIRS 174191], Section 6.2.30). Therefore, the magnitude and time of the resulting radiological exposures to the RMEI or radionuclide releases to the accessible environment would not be significantly changed by the exclusion of this FEP, and it is excluded on the basis of low consequence.

TSPA Disposition:

N/A

Supporting Documents:

N/A

\subsubsection{Diffusion of Colloids in EBS}

FEP Number:

2.1.09.24.0A

FEP Description: Colloidal particles, together with any associated actinides, that are sufficiently small may be transported through the EBS by diffusion.

Screening Decision:

Included

Screening Argument:

N/A

TSPA Disposition: The general colloid-facilitated diffusive transport model and implementation in TSPA-LA are described in EBS Radionuclide Transport Abstraction (BSC 2005 [DIRS 173433], Section 6.3.4.4). The concentration of colloids in each region of the EBS, specifically in the waste form domain, the waste package corrosion products domain, and the invert domain, is determined in part by the local chemical environment. The diffusion coefficient for all colloidal particles, regardless of size, is estimated to be a factor of 100 less than the diffusion coefficient for dissolved radionuclides (BSC 2005 [DIRS 173433], Sections 6.3.4.4 and 6.5.1.2) and is implemented accordingly in TSPA-LA. A discussion of colloid transport in the EBS is presented in Sections 6.3.4.4 and 6.5.1.2 of EBS Radionuclide Transport Abstraction (BSC 2005 [DIRS 173433]). Other factors involving diffusion areas and path lengths are also specified in the RTA model.

The model developed in EBS Radionuclide Transport Abstraction (BSC 2005 [DIRS 173433]) is used to quantify the time-dependent radionuclide releases, including actinides, from a failed waste package and their subsequent transport through the EBS to the emplacement drift wall/UZ interface. The basic inputs to the RTA model consist of the drift seepage influx, the environmental conditions in the drift (temperature, relative humidity, water chemistry), and the degradation state of the EBS components (BSC 2005 [DIRS 173433], Section 4.1). Outputs consist of the rates of radionuclide releases to the $\mathrm{UZ}$ as a result of advective and diffusive transport, accounting for the impact of colloids, radionuclide solubility, retardation, and the degree of liquid saturation of the waste form and invert materials (BSC 2005 [DIRS 173433], Section 8.2). The RTA model is implemented directly into the TSPA-LA GoldSim model to compute the radionuclide release rates from the EBS. 
The source of inflow to the EBS is the seepage flux that drips from the crown (roof) of the drift and imbibition flux from the UZ into the invert. This inflow can flow through the EBS along eight pathways: (1) seepage flux, (2) flux through the drip shield, (3) diversion around the drip shield, (4) flux through the waste package, (5) diversion around the waste package, (6) flux from the waste package into the invert, (7) imbibition flux from the UZ matrix to the invert, and (8) flux from the invert to the UZ fractures (BSC 2005 [DIRS 173433], Section 6.3.1.1 and Figure 6.3-1). These pathways are time dependent, in the sense that drip shield gaps, drip shield penetrations, and waste package penetrations will vary with time and local conditions in the repository.

The conceptual model for flow through the EBS also includes three domains: the waste form (e.g., fuel rods or DHLW glass) and cladding, waste package corrosion products, and the invert. Because the presence of the emplacement pallet is ignored, water and radionuclides pass directly from the waste package and cladding to the invert (BSC 2005 [DIRS 173433], Section 6.3.1.1).

The formation, stability, and concentration of colloids are addressed in Waste Form and In-Drift Colloids-Associated Radionuclide Concentrations: Abstraction and Summary (BSC 2005 [DIRS 174290]).

\section{Supporting Documents:}

BSC 2005 [DIRS 173433]

\subsubsection{Gravitational Settling of Colloids in EBS}

\section{FEP Number:}

$$
\text { 2.1.09.26.0A }
$$

FEP Description: Over the relatively short transport distances within the waste package, colloidal particles may experience gravitational settling, thereby inhibiting transport.

\section{Screening Decision:}

Excluded (Low Consequence)

Screening Argument: The TSPA considers that all radionuclide-bearing colloids generated from waste form degradation within a failed waste package will leave the waste package and enter the drift and EBS. Settling of these radionuclide-bearing colloids could result in some retardation of the colloid transport. In Waste Form and In-Drift Colloids-Associated Radionuclide Concentrations: Abstraction and Summary (BSC 2005 [DIRS 174290], Section 7.2), physical filtration and gravitational settling of colloids are assumed not to occur. All stable colloids are assumed to leave a failed waste package through the failure opening. This assumption overestimates the potential consequences of colloid-facilitated transport of radionuclides and is considered bounding. Therefore, the magnitude and time of the resulting radiological exposures to the RMEI or radionuclide releases to the accessible environment would not be significantly changed by the omission of gravitational settling of colloids, and this FEP is excluded on the basis of low consequence.

\section{TSPA Disposition:}

N/A 


\section{Supporting Documents:}

N/A

\subsubsection{Coupled Effects on Radionuclide Transport in EBS}

\section{FEP Number:}

2.1.09.27.0A

FEP Description: Repository induced changes to the physical and chemical properties of the EBS and waste form may be important for evaluating radionuclide transport in the EBS. The existence of chemical gradients within the disposal system, resulting from repository material, waste emplacement, and corrosion products, may influence the transport of dissolved and colloidal species. This could include: geochemical reactions that move (pump) radionuclides; effects on advection, diffusion, and sorption within and through failed waste packages; and microbial and electrochemical effects.

\section{Screening Decision:}

Excluded (Low Consequence)

Screening Argument: Coupled processes refer to two or more physical and chemical processes simultaneously interacting to produce a result, or to cases where a process is affected by physical and chemical variables at the same time. The coupled processes considered in TSPA-LA involve the transport of chemicals, including radionuclides, which can affect dose calculations.

Certain one-way coupling processes are considered important by the NRC, as discussed in $A$ Literature Review of Coupled Thermal-Hydrologic-Mechanical-Chemical Processes Pertinent to the Proposed High-Level Nuclear Waste Repository at Yucca Mountain (Manteufel et al. 1993 [DIRS 100776]). These are thermal-hydrologic (vaporization and condensation, dripping in fractures, and buoyancy driven unsaturated flow), hydrologic-thermal (gravity driven heat pipes), thermal-mechanical (thermally induced stress), thermal-chemical (effects on equilibrium and activity, and effects on nonequilibrium chemistry), hydrologic-chemical (equilibrium solute transport, nonequilibrium solute transport), chemical-hydrologic (mineral deposition in fractures), and chemical-mechanical (chemical effects on rock fracture propagation, stress corrosion cracking). These coupled processes are described in the following FEPs or reports and are not covered in this FEP:

- Effects of corrosion products on in-drift water chemistry and gas composition are evaluated in Engineered Barrier System: Physical and Chemical Environment (BSC 2005 [DIRS 175083], Sections 6.8 and 6.7) and discussed in Section 6.2.46 of the present document under FEP 2.1.09.02.0A. Such effects could influence corrosion product formation and transport.

- Effects of degraded waste package on transport (see FEPs 2.1.09.08.0A and 2.1.09.08.0B in Sections 6.2.51 and 6.2.52, respectively, of the present report) are evaluated for radionuclide transport in EBS Radionuclide Transport Abstraction (BSC 2005 [DIRS 173433], Section 6.3.4). 
- Mineral deposition in fractures is included in FEP 2.2.08.03.0B of Features, Events, and Processes in UZ Flow and Transport (BSC 2005 [DIRS 174191], Section 6.9.7) as part of the $\mathrm{UZ}$ and drift near-field analysis.

- Thermal effects on chemical equilibria are examined in Engineered Barrier System: Physical and Chemical Environment (BSC 2005 [DIRS 175083], Section 6.5), Drift Scale THC Seepage Model (BSC 2005 [DIRS 172862], Section 6.2.1) and In-Drift Precipitates/Salts Model (BSC 2004 [DIRS 169863], Section 6.3). Such effects are also discussed in Sections 6.2.45 and 6.2.70 of the current report under FEPs 2.1.09.01.0A and 2.1.11.08.0A, respectively.

- Thermal effects on chemical reaction rates are explicitly included in Drift-Scale THC Seepage Model (BSC 2005 [DIRS 172862], Section 6.4), as well as in Sections 6.2.50 and 6.2.70 of the current report under FEPs 2.1.09.07.0B and 2.1.11.08.0A, respectively.

- Evaporation and condensation processes are evaluated in Sections 6.2.35 and 6.2.41 of this report under FEPs 2.1.08.04.0A and 2.1.08.11.0A, respectively.

- Stress corrosion cracking of waste package metals is discussed in Screening of Features, Events, and Processes in Drip Shield and Waste Package Degradation (BSC 2005 [DIRS 174995], Section 6.2.4) under FEP 2.1.03.02.0A.

- Effects of flow processes on transport are discussed in the various FEPs documents as follows: for the UZ (BSC 2005 [DIRS 174191]), under FEPs 2.2.07.04.0A, 2.2.07.06.0B, 2.2.07.08.0A, 2.2.10.10.0A, and 2.2.07.18.0A; for the EBS (the current report), under FEPs 2.1.08.05.0A, 2.1.08.07.0A, and 2.2.07.06.0B; and for the saturated zone (BSC 2005 [DIRS 174190]), under FEP 2.2.08.08.0A.

Onsager couplings are driven indirectly by gradients of thermodynamic state variables (e.g., temperature, pressure, chemical potential, and electrical potential) that affect chemical transport in aqueous solutions. Direct transport processes are driven by the same thermodynamic state variables in well-known relations such as Fourier's Law, Fick's Law, and Ohm's Law. Diffusive processes dominate in Onsager-coupled processes and the direct transport processes described above. Also see Engineered Barrier System: Physical and Chemical Environment (BSC 2005 [DIRS 175083], Section 6.3) for a general discussion of Onsager couplings.

Discussion for exclusion of other, second-order coupled-processes due to low consequence is included below.

The generation of electric fields around HLW packages is caused by Compton electron scattering, as documented by Green et al. (1987 [DIRS 170174]). Those authors assumed completely degraded canisters with no shielding effect by cladding or canister wall. They calculated that the electric field at $10 \mathrm{~cm}$ would be much greater in air $\left(10^{+2} \mathrm{~V} / \mathrm{cm}\right)$ than in rock $\left(10^{-8.5} \mathrm{~V} / \mathrm{cm}\right)$ at 300 years. Furthermore, electric fields would systematically decrease with both distance and age of the waste package. However, since photon energies are severely degraded by solids with high $\mathrm{z}$, the intact 7 -cm waste package iron packaging (and 2-cm Alloy 22) would degrade the electronic field in air outside the waste package to a value similar to that calculated 
for solid rock at $10 \mathrm{~cm}$. Therefore, an intact canister would supply an electron field of only approximately $10^{-8.5} \mathrm{~V} / \mathrm{cm}$ at 300 years. This value is minimal and can therefore be discounted due to low consequence.

The thermal diffusion effect (Soret effect) on radionuclide transport is discussed in FEP 2.1.11.10.0A (section 6.2.73). Another possible expression of this effect may occur in the gas phase, at locations with steep thermal gradients as discussed below. According to Bird et al. (1960 [DIRS 103524], pp. 565 to 567), "The thermal diffusion term [Soret effect] describes the tendency for species to diffuse under the influence of a temperature gradient; this effect is quite small." Hirschfelder et al. (1967 [DIRS 171800], p. 8) state that "Diffusion may also result from a temperature gradient (thermal diffusion or the Soret effect), and the transfer of energy may also result from a concentration gradient (diffusion thermo or Dufour effect). These are small effects." In the EBS, areas with steep temperature gradients during the heating pulse will often have temperatures above the boiling point. Therefore, there will be little or no liquid available for thermal diffusion. When temperatures are below the boiling point of water, the coupled effect of thermodiffusion and thermogravitation as described by Vidal and Murphy (1999 [DIRS 171801]) could affect relative humidity distributions. This coupling can exert the separation of water vapor and gas in an area delineated by the nature of the empty space between hot and cold surfaces. This separation may induce the formation of spatially specific relative humidity environments with respect to the geometry of EBS components in the drift and could therefore affect corrosion of EBS materials through the formation of water condensate. The study by Vidal and Murphy (1999 [DIRS 171801]) concludes that gaps between the relatively hot and cold surfaces (i.e., waste package and drip shield or drip shield and drift wall) exceeding $5 \mathrm{~cm}$ will not generate significant thermogravimetric and thermodiffusive effects. The gaps between waste package and drip shield, and drip shield and drift wall, are very much larger than those considered in their study, which focused on scenarios where backfill material is present.

Microbial effects on sorption in the EBS are considered in Section 6.2.65 of the current report under FEP 2.1.10.01.0A. Electrochemical effects in the EBS are considered in FEP 2.1.09.09.0A in Clad Degradation - FEPs Screening Arguments (BSC 2004 [DIRS 170019], Section 6.2.20). Chemical effects on rock fracture permeability are considered in FEP 2.2.10.06.0A of Features, Events, and Processes in UZ Flow and Transport (BSC 2005 [DIRS 174191], Section 6.9.13). Thermally induced stress is considered in FEPs 2.2.01.02.0A, 2.2.10.04.0A, 2.2.10.04.0B, and 2.2.10.05.0A of that same report (BSC 2005 [DIRS 174191], Sections 6.9.3, 6.9.10, 6.9.11, and 6.9.12, respectively).

In summary, the potential coupled effects on radionuclide transport not covered by other FEPs are a second order effect on the primary transport phenomena present in the nominally developed models governing transport in the EBS. As such, their omission from the TSPA-LA will not have a significant effect on the magnitude and time of the resulting radiological exposures to the RMEI or radionuclide releases to the accessible environment.

TSPA Disposition:

N/A

\section{Supporting Documents:}

N/A 


\subsubsection{Localized Corrosion on Waste Package Outer Surface Due to Deliquescence}

\section{FEP Number:}

\subsection{A}

FEP Description: Salt-containing dust, which could accumulate on the waste package surface during the preclosure ventilation period, can absorb moisture from the drift atmosphere, even at low relative humidity, dissolving the salt and creating concentrated aqueous solutions. This deliquescence process may result in localized surface chemistry that could cause penetration of the waste package outer barrier by localized corrosion.

\section{Screening Decision:}

Excluded (Low Consequence)

Screening Argument: The analysis for this FEP is focused on the potential for dust deliquescence to influence the localized corrosion of the waste package. An analysis of the general corrosion of the waste package, including impacts from dust on general seepage and RH considerations, is presented in Screening of Features, Events, and Processes in Drip Shield and Waste Package Degradation (BSC 2005 [DIRS 174995], FEP 2.1.03.01.0A, Section 6.2.2). An analysis of localized corrosion of the waste package due to other causes (such as seepage) is presented in Screening of Features, Events, and Processes in Drip Shield and Waste Package Degradation (BSC 2005 [DIRS 174995], FEP 2.1.03.03.0A, Section 6.2.6).

Dust will be deposited on the surfaces of waste packages in emplacement drifts during the operational and the preclosure ventilation periods. After emplacement, there is a period of about 700 to 1,000 years in which no seepage is possible because the drift wall temperature is above boiling (BSC 2005 [DIRS 175058], Appendix E, Section E-1). During this interval, the only aqueous phase that could potentially contact the waste package (even if the drip shields do not perform their function) is brine that originates by deliquescence of soluble salts in dust deposited on the waste package during emplacement and ventilation. The potential for brines formed by dust deliquescence to initiate and sustain localized corrosion that results in failure of the waste package outer barrier and early failure of the waste package has been evaluated in Analysis of Dust Deliquescence for FEP Screening (BSC 2005 [DIRS 175058], Section 7.1). This evaluation shows that dust deliquescence-induced localized or crevice corrosion of the waste package outer barrier (Alloy 22) is of low consequence with respect to repository performance (BSC 2005 [DIRS 175058], Section 7.1.5).

Measured atmospheric and underground dust compositions are the basis of thermodynamic modeling and experimental studies to evaluate the likelihood of brine formation (BSC 2005 [DIRS 175058], Section 6.1) and persistence (BSC 2005 [DIRS 175058], Section 6.2), the volume of brines that may form (BSC 2005 [DIRS 175058], Section 6.4), and the relative corrosivity of the initial deliquescent brines and of brines modified by processes on the waste package surface (BSC 2005 [DIRS 175058], Section 6.3). In addition, several mechanisms that could inhibit or stifle localized corrosion should it initiate are evaluated (BSC 2005 [DIRS 175058], Section 6.5). 
The dust compositions considered include both tunnel dust samples from Yucca Mountain and National Airfall Deposition Program precipitation data representing atmospheric dust compositions in southwestern Nevada. Also considered is thermal decomposition of ammonium salts, a process that could affect dust composition prior to deliquescence. Ammonium chlorides, nitrates, and even sulfates thermally decompose readily into ammonia and acid gasses, and will be lost from the surface of the waste package prior to deliquescence (BSC 2005 [DIRS 175058], Section 6.1.2.3).

Arguments are developed using a logical framework approach, considering a wide range of dust and brine compositions, conditions on the waste package, and processes (BSC 2005 [DIRS 175058], Sections 1.1 and 7). Any uncertainty or variation in the input parameter values, within a reasonably expected range, will not change the conclusions drawn in Analysis of Dust Deliquescence for FEP Screening (BSC 2005 [DIRS 175058], Section 7). In order for dust deliquescence-induced localized corrosion to result in penetration of the waste package outer barrier, each of the following propositions must be affirmative:

1) Can multiple-salt deliquescent brines form at elevated temperature? Yes (see BSC 2005 [DIRS 175058], Table 7.1-1). As discussed in Analysis of Dust Deliquescence for FEP Screening (BSC 2005 [DIRS 175058], Section 7.1.1), multi-salt deliquescent brines can form at elevated temperature (above $120^{\circ} \mathrm{C}$ ). Ammonium salts will comprise a significant fraction of the salts in the dust, but readily thermally decompose and will not persist long enough to contribute to deliquescent mineral assemblages, thus significantly decreasing the salt load present for deliquescence. For most single salt phases (nitrates, chlorides, and carbonates) boiling points at one atmosphere are limited to temperatures below $120^{\circ} \mathrm{C}$-boiling points of saturated salt solutions represent the maximum temperature of deliquescence at a given pressure. Saturated multi-salt mixtures always boil at higher temperatures than the individual salt components. The boiling points for important salt assemblages predicted to occur on the waste package surface have been investigated experimentally. The two-salt mixture $\mathrm{NaCl}+\mathrm{KNO}_{3}$ boils at a maximum temperature of $134^{\circ} \mathrm{C}$ and the three-salt mixture, $\mathrm{NaCl}+\mathrm{KNO}_{3}+\mathrm{NaNO}_{3}$, at over $190^{\circ} \mathrm{C}$. By inference, the four-salt mixture, $\mathrm{NaCl}+\mathrm{KNO}_{3}+\mathrm{NaNO}_{3}+\mathrm{Ca}\left(\mathrm{NO}_{3}\right)_{2}$, must also deliquesce at temperatures above $190^{\circ} \mathrm{C}$.

2) If brines form at elevated temperature, will they persist? Sometimes (see BSC 2005 [DIRS 175058], Table 7.1-1). As discussed in Analysis of Dust Deliquescence for FEP Screening (BSC 2005 [DIRS 175058], Section 7.1.2), multi-salt brines can persist on the waste package surface but are not stable. Acid degassing will occur rapidly at first, increasing the $\mathrm{pH}$ to near-neutral or alkaline conditions. Further degassing results in dryout, producing an assemblage of less deliquescent salts that yield a higher $\mathrm{pH}$ solution when they redeliquesce. Experimental work has shown that deliquescent $\mathrm{CaCl}_{2}$ brine readily degasses at elevated temperature, producing a less deliquescent salt. For degassing of $\mathrm{HCl}$ and $\mathrm{HNO}_{3}$ from brines dominated by monovalent salts (e.g., $\mathrm{NaCl}, \mathrm{NaNO}_{3}, \mathrm{KNO}_{3}$ ), dissolution of $\mathrm{CO}_{2}$ into the brine prolongs the degassing process and increases the conversion to less deliquescent salts (e.g., $\mathrm{NaHCO}_{3}$ ). The immediate result of degassing is increased $\mathrm{pH}$, and the long-term result is precipitation of less deliquescent salts - however, sufficient degassing to result in complete dryout 
is unlikely for most brine compositions. Should dryout occur, these salts may subsequently deliquesce at lower temperature and higher RH, producing brines with higher $\mathrm{pH}$ than the original assemblage. Higher $\mathrm{pH}$ brines are more benign with respect to localized corrosion of Alloy 22.

3) If deliquescent brines persist, are they corrosive? No (see BSC 2005 [DIRS 175058], Table 7.1-1). As discussed in Analysis of Dust Deliquescence for FEP Screening (BSC 2005 [DIRS 175058], Section 7.1.3), brines formed by deliquescence of tunnel dusts or atmospheric aerosols are benign, and will remain so as they are modified by processes that occur on the waste package surface. Nitrate is a significant moderator of localized corrosion, and the various salt and brine evolution processes investigated cause the ratio of nitrate/chloride to increase. Nitrate is a major component of the soluble fraction of tunnel dusts and atmospheric airfall or rainfall analyses. Initial brines formed by deliquescence of multi-salt assemblages will have near-neutral $\mathrm{pH}$, and they will be nitrate-rich and chloride-poor. Experimental corrosion studies used to develop the localized corrosion model have verified that corrosion will not be initiated by nitrate-rich brines (nitrate to chloride ratio at 0.5 or greater) at temperatures below $120^{\circ} \mathrm{C}$. Based on thermodynamic principles, brines potentially forming at higher temperatures can only be more nitrate-rich than at lower temperatures because the chloride salts are relatively less soluble. Higher-temperature data indicate that general corrosion mechanisms do not change up to temperatures of $220^{\circ} \mathrm{C}$, suggesting that nitrate inhibition of localized corrosion may continue to be effective at elevated temperatures. Processes occurring after deliquescence, including acid degassing and reactions with silicate minerals, do not result in corrosive brines (BSC 2005 [DIRS 175058], Section 6.3.4). Acid degassing has beneficial effects, increasing the nitrate/chloride ratio of the remaining solution, and even small degrees of degassing will result in increases in the brine $\mathrm{pH}$, to values ranging from near-neutral to alkaline. Brine interactions with silicate minerals may also buffer the $\mathrm{pH}$ to near-neutral or slightly alkaline values, and may lead to dryout by precipitation of a less deliquescent salt assemblage.

4) If deliquescent brines are potentially corrosive, will they initiate localized corrosion? No (see BSC 2005 [DIRS 175058], Table 7.1-1). As discussed in Analysis of Dust Deliquescence for FEP Screening (BSC 2005 [DIRS 175058], Section 7.1.4), even if potentially corrosive, brines formed by dust deliquescence will be limited in volume, and physical separation of salt minerals in the dust could further reduce potential brine volumes by limiting the occurrence of eutectic mineral assemblages. Capillary and surface tension effects in the dust are likely to reduce surface contact or inhibit brine flow into pores or crevices. Characterization of dust porosity indicates that a typical dimension of about one micron characterizes the capillary response of the dust. This dimension suggests that brine flow through the dust will be inhibited, and that pores or crevices on the metal surface would have to have similar dimension in order to compete successfully for the brine. Furthermore, predicted brine droplet volumes or layer thicknesses are too small to maintain chemical gradients necessary for localized corrosion on the flat surface (e.g., pitting), e.g., the differences in $\mathrm{O}_{2}$ concentration required to develop the separate anodic and cathodic zones necessary for initiation of localized corrosion on a flat surface. However, this inhibiting action may not be 
effective in deep crevices, even for unsaturated (non-immersion) conditions, depending on the accessibility of the Alloy 22 surface to air.

5) Once initiated, will localized corrosion penetrate the waste package outer barrier? No (see BSC 2005 [DIRS 175058], Table 7.1-1). Several processes will act to slow or stifle localized corrosion before penetration of the waste package outer barrier occurs. Water is consumed by redox reactions in both the anodic and cathodic regions of the corrosion cell. This water must be replaced by condensation of moisture from the gas phase for corrosion to continue. As corrosion products accumulate in the cell, cathodic limitation will occur as secondary products precipitate and coat the metal surface, limiting brine contact and potentially decreasing availability of oxygen and moisture if transport pathways through the corrosion products are limited. A power law rate equation is applicable to localized or crevice corrosion penetration of Alloy 22 , as well as to many other materials. Laboratory data clearly show that stifling of crevice corrosion in Alloy 22 occurs with time. Although experimental data for unforced localized corrosion of Alloy 22 are unavailable, stifling represents diffusion control of reaction rate, with limitation from precipitated material and transport losses in the brine film that will occur. In addition, physical and chemical sequestration of brine and brine components will limit localized corrosion penetration. Corrosion products formed by localized or crevice corrosion would have to be nearly nonporous not to volumetrically deplete the aqueous brine phase by physical incorporation or capillary retention. In addition, corrosion products have been identified experimentally that contain brine components $\left(\mathrm{Cl}^{-}\right)$, and thermodynamic analysis indicates that these phases may also form in deliquescent brines. Thus, the small volumes of brine available at elevated temperature (above $120^{\circ} \mathrm{C}$ ) will limit the progress of localized corrosion on the waste package, compared with laboratory experiments performed with far greater brine volumes (e.g., immersion conditions) or forced polarization. Localized corrosion of the waste package is further discussed in FEP 2.1.03.03.0A in Screening of Features, Events, and Processes in Drip Shield and Waste Package Degradation (BSC 2005 [DIRS 174995], Section 6.2.6).

In summary, brines formed by deliquescence of tunnel and atmospheric dust compositions are chemically benign with respect to localized corrosion. Processes that act to modify them on the waste package surface are beneficial with respect to corrosivity. Should corrosive brines form, scale factors related to brine volume will inhibit initiation of localized corrosion. Finally, should corrosion initiate, several processes will act to limit or stifle it before penetration of the waste package outer barrier (BSC 2005 [DIRS 175058], Section 7). FEP 2.1.09.28.0A, Localized Corrosion on Waste Package Outer Surface due to Deliquescence, is shared with Screening of Features, Events, and Processes in Drip Shield and Waste Package Degradation (BSC 2005 [DIRS 174995], Section 6.2.18).

Due to the aforementioned analysis, dust deliquescence will not impact the localized corrosion of the waste package. Therefore, FEP 2.1.09.28.0A is excluded from consideration of impacts to the in-drift chemical environment in the TSPA-LA on the basis of low consequence. Its exclusion from the TSPA-LA will not have a significant effect on the magnitude and time of the resulting radiological exposures to the RMEI or radionuclide releases to the accessible environment. 


\section{TSPA Disposition:}

N/A

\section{Supporting Documents:}

N/A

\subsubsection{Localized Corrosion on Drip Shield Surfaces Due to Deliquescence}

\section{FEP Number:}

2.1.09.28.0B

FEP Description: Salt-containing dust, which could accumulate on the drip shield surface during the preclosure ventilation period, can absorb moisture from the drift atmosphere, even at low relative humidity, dissolving the salt and creating concentrated aqueous solutions. This deliquescence process may result in localized surface chemistry that could cause penetration of the drip shield surface by localized corrosion.

\section{Screening Decision:}

Excluded (Low Consequence)

Screening Argument: The analysis for this FEP is focused on the potential for dust deliquescence to influence the localized corrosion of the drip shield. An analysis of the general corrosion of the drip shield, including impacts from dust on general seepage and RH considerations, is presented in Screening of Features, Events, and Processes in Drip Shield and Waste Package Degradation (BSC 2005 [DIRS 174995], Section 6.2.3, FEP 2.1.03.01.0B).

The behavior of the Titanium Grade 7 drip shield material with respect to localized corrosion has been modeled as discussed in General Corrosion and Localized Corrosion of the Drip Shield (BSC 2004 [DIRS 169845], Section 6.6). That analysis concludes that localized corrosion of Titanium Grade 7 would not initiate under any repository-relevant environments even at $\mathrm{pH}$ values as high as 14 (BSC 2004 [DIRS 169845], Section 8.4). The analysis further concludes that localized corrosion initiation does not need to be implemented in TSPA (BSC 2004 [DIRS 169845], Section 8.4).

A more detailed analysis of the exclusion of localized corrosion of the drip shield from TSPA is presented in Screening of Features, Events, and Processes in Drip Shield and Waste Package Degradation (BSC 2005 [DIRS 174995], Section 6.2.7, FEP 2.1.03.03.0B). That analysis concludes that localized corrosion of the drip shield will not occur over all ranges of $\mathrm{pH}$, chloride concentrations, and temperatures in the repository.

Due to the aforementioned analysis, dust deliquescence will not impact the localized corrosion of the drip shield. Therefore, FEP 2.1.09.28.0B is excluded from consideration of impacts to the in-drift chemical environment in the TSPA-LA on the basis of low consequence. Its exclusion from the TSPA-LA will not have a significant effect on the magnitude and time of the resulting radiological exposures to the RMEI or radionuclide releases to the accessible environment.

TSPA Disposition:

N/A 


\section{Supporting Documents:}

N/A

\subsubsection{Advection of Liquids and Solids through Cracks in the Waste Package}

\section{FEP Number:}

$$
\text { 2.1.03.10.0A }
$$

FEP Description: The presence of one or more cracks or other small openings of sufficient size in a waste package may provide a pathway for the advective flow of water (e.g., thin films or droplets) or solid material into the waste package. The resulting presence of sufficient water or solid material in the waste package may affect in-package chemistry and/or criticality. Partial or full plugging of the waste package cracks by chemical or physical reactions after their formation (i.e., healing) could also affect water flow and radionuclide transport through the waste package. Passivation by corrosion products is a potential mechanism for waste package healing.

\section{Screening Decision:}

Excluded (Low Consequence)

Screening Argument: The waste packages are fully annealed prior to closure welding, and treated after closure welding, so that stress corrosion cracks (SCCs) are unlikely but may occur on the lids, as discussed in Screening of Features, Events, and Processes in Drip Shield and Waste Package Degradation (BSC 2005 [DIRS 174995], Section 6.2.4). Damaged areas could occur in response to impact of the waste package on the emplacement pallet and end-to-end impact of adjacent waste packages that will result in deformations and resultant sustained residual stresses that may initiate cracks. Cracks could initiate when the residual stress exceeds 80 and $90 \%$ of the yield stress of Alloy 22, as discussed in Seismic Consequence Abstraction (BSC 2005 [DIRS 173247], Section 6.3.2). The abstraction of this potential for damage is discussed under FEP 1.2.03.02.0A in Section 6.2.8 of the current report.

Even if stress corrosion cracking of the waste package occurs, cracks in passive alloys such as Alloy 22 tend to be tight (i.e., small crack-opening displacement), as discussed in Stress Corrosion Cracking of the Drip Shield, the Waste Package Outer Barrier, and the Stainless Steel Structural Material (BSC 2004 [DIRS 172203], Section 1). Typically, the stress corrosion cracks are tortuous and often with many branches (BSC 2004 [DIRS 172203], Section B6.1).

EBS Radionuclide Transport Abstraction (BSC 2005 [DIRS 173433], Section 6.3.3) provides a prediction of crack aperture size for the cracks in the waste package. A range of crack aperture values are calculated using the estimated residual stress (from finite element simulations) and the crack length (approximately twice the lid thickness). EBS Radionuclide Transport Abstraction (BSC 2005 [DIRS 173433], Section 6.3.3 and Table 6.3-3) calculates crack widths at the inner and outer surfaces of $118 \mu \mathrm{m}$ and $196 \mu \mathrm{m}$, respectively, through radial cracks in the waste package lid, using the method outlined in Stress Corrosion Cracking of the Drip Shield, the Waste Package Outer Barrier, and the Stainless Steel Structural Material (BSC 2004 [DIRS 172203], Section 6.5.2).

Analysis of water holding capacity for idealized parallel-plate geometry is developed in Water Distribution and Removal Model (BSC 2001 [DIRS 152016], Section 6.1.4, Table 6.1). The 
analysis is based on the retention of water in any aperture represented by two vertical parallel plates in which the weight of the water retained by the plates is resisted by surface tension (BSC 2000 [DIRS 152016], Equations 6.9 and 6.10). The relationship of the contact angle to the water holding capacity or aperture width, and the thickness of the drip shield, was used to conduct a parametric study (BSC 2000 [DIRS 152016], Table 6-1). The analysis shows that for a penetration through a $15 \mathrm{~mm}$ plate, the maximum smooth-wall aperture for retention of liquid water is approximately $0.9 \mathrm{~mm}$ based on a contact angle of $180^{\circ}$ (BSC 2001 [DIRS 152016], Table 6-1). The same effect would be present in a waste package outer barrier, although the thickness is greater, so the maximum aperture of a crack would be smaller proportionally. Smaller apertures such as those produced by SCCs have greater holding capacity that resists advective flow because: 1) capillary behavior allows water to reside indefinitely within the crack without flow (BSC 2001 [DIRS 152016], Section 6.1.1.2); 2) surface tension opposes hydraulic pressure that may be present at the outlet (BSC 2001 [DIRS 152016], Section 6.1.1.2); and 3) SCCs are tight, rough, and tortuous (BSC 2004 [DIRS 172203], Section B6.1), which limits the transient response to dripping water.

Changes in atmospheric pressure (such as from barometric pumping) could provide additional driving pressure; however, breakthrough of air would occur readily (along with a small amount of liquid water) and lead to equalization. The potential effects from small amounts of liquid water entering the waste packages have been analyzed. The waste package, being an enclosed volume with internal heat production, has the capacity to vaporize and reject liquid water that may enter through cracks, as discussed in Water Pooling-Evaporation in a Waste Package (CRWMS 2000 [DIRS 149626], Section 6).

In the repository, where water is available in rock pores in the liquid and vapor phase, thin water films can be assumed to exist below $100^{\circ} \mathrm{C}$, and above $100^{\circ} \mathrm{C}$ the thin film would evaporate because water will boil at or below $100^{\circ} \mathrm{C}$. Additional justification for this approach is provided in EBS Radionuclide Transport Abstraction (BSC 2005 [DIRS 173433], Section 5.5). Once stress corrosion cracks form in the lid of the waste package, all surfaces inside the waste package are assumed to be coated with a thin film of water (BSC 2005 [DIRS 173433], Section 6.3.4.5). These films may slowly migrate due to gravitational forces, but are not a source of dripping (BSC 2005 [DIRS 173433], Section 8.1).

An analysis of stress corrosion cracking for the drip shield Titanium Grade 7 material is provided in Stress Corrosion Cracking of the Drip Shield, the Waste Package Outer Barrier, and the Stainless Steel Structural Material (BSC 2004 [DIRS 172203], Section 6.3.7). It is expected that stress corrosion cracking morphology in Titanium Grade 7 is similar to that of Alloy 22 (i.e., the waste package outer barrier) because of the crystalline granular structure of these alloys. Therefore, the analysis of stress corrosion cracking in the drip shield can be applied to the waste package. As SCCs form and grow, the exposed crack faces continue to corrode at very low passive corrosion rates, forming corrosion products with greater molar volume than the original alloy material (BSC 2004 [DIRS 172203], Section 6.3.7). In addition, water originating either as condensate or seepage, or water-dust mixtures that enter SCCs, will warm because of its closer proximity to the heat of the waste packages. This will cause precipitation of minerals such as calcite which have retrograde solubility (depending on the availability of solutes). Over time, corrosion products, precipitated minerals, and particles of dust and rock in the environment will plug the crack. Stress corrosion cracks can be clogged in a few hundred years depending on the 
rate of water inflow (BSC 2004 [DIRS 172203], Section 6.3.7). When the cracks are fine enough to remain bridged by stationary water, the clogging process could take thousands of years, during which through-flow is resisted by capillary forces. As SCCs undergo clogging, the effective aperture decreases and the capillary response increases, further limiting mobility of liquid water for flow. These processes, which are predicted to occur in the drip shield, can be expected in the waste package outer barrier as well.

In summary, advection of liquid and solid material through SCCs in the waste package outer barrier is limited, and is unlikely to admit significant quantities of liquid water into the waste package. Such water would readily equilibrate with the gas-phase inside the waste package, and the effects of such water would be the same as from water vapor. The potential flow through SCCs is so small that its omission from the TSPA-LA has an insignificant effect on the magnitude and time of the resulting radiological exposures to the RMEI or radionuclide releases to the accessible environment. Therefore, this FEP, in conjunction with FEP 2.1.03.02.0A (BSC 2005 [DIRS 174995], Section 6.2.4), is excluded based on low consequence.

TSPA Disposition:

N/A

Supporting Documents:

N/A

\subsubsection{Advection of Liquids and Solids through Cracks in the Drip Shield}

\section{FEP Number:}

2.1.03.10.0B

FEP Description: The presence of one or more cracks or other small openings of sufficient size in a drip shield may provide a pathway for the advective flow of water (e.g., thin films or droplets) or solid material through the drip shield. The resulting flux may affect drip shield performance and/or subsequent dripping onto the waste packages. Partial or full plugging of the drip shield cracks by chemical or physical reactions after their formation (i.e., healing) could also affect water flow through the drip shield.

\section{Screening Decision:}

Excluded (Low Consequence)

Screening Argument: The drip shields may be subject to stress corrosion cracking under repository conditions. The sources of stress that could result in stress corrosion cracks (SCCs) in the Titanium Grade 7 drip shields include (1) weld-induced residual stress, (2) plasticity-induced residual stress caused by seismic events, and (3) residual stress produced by rock falls, as discussed in Stress Corrosion Cracking of the Drip Shield, the Waste Package Outer Barrier, and the Stainless Steel Structural Material (BSC 2004 [DIRS 172203], Section 6.3.7). The weld induced residual stress in the drip shields will be mitigated by annealing before placement in the drifts, as discussed in the drip shield fabrication specification summary of IED Interlocking Drip Shield and Emplacement Pallet [Sheet 1 of 1] (BSC 2005 [DIRS 173303]). Therefore, drip shields are not subject to stress corrosion cracking upon emplacement. However, the drip shields are subject to stress corrosion cracking under the action of seismic-induced loading and rockfall. 
Rockfall/seismic effects on drip shield degradation are discussed in FEPs 2.1.07.01.0A, Rockfall, and 1.2.03.02.0B, Seismic-Induced Rockfall Damages EBS Components (sections 6.2.28 and 6.2.9 of the present report, respectively). This FEP (2.1.03.10.0B) considers rockfall events and the subsequent drip shield structural response in the possible development of through-wall cracks in the drip shield that may provide a pathway for the advective flow of water through the drip shield.

The net effect of rockfall and seepage is demonstrated to be of minor consequence following the logic below:

- Since $85 \%$ of the repository emplacement area is located in lithophysal rocks that do not produce blocks capable of denting the drip shield (Section C.1), the number of drip shields that could be affected by rockfall is small relative to the total number of drip shields in the repository.

- A relatively small number of blocks fall in the nonlithophysal units that could damage drip shields and create dents that could act to catch and funnel seepage to through-going cracks in the drip shield. The probability for these blocks to fall is shown in Appendix C to be small due to the probability of the causal seismic events (Section C.2.3). Significant conservatisms in the probability analysis include the following:

- A large rock block is a partly fractured structure that is likely to crumble or partly shatter on impact with the drip shield. However, the potential for block failure is not included in the structural response calculations.

- Smaller rock blocks that partly shelter the drip shield from direct impact often precede large rock blocks. The potential for rubble to distribute the impact loads is not included in the structural response calculations.

- The orientation and shape of rock blocks is conservatively chosen to maximize damage by locating the center of mass directly above the impact point. Blocks have a cubic shape for the LS-DYNA calculations, with the center of mass directly above an edge that contacts the crown of the drip shield. Based on the rockfall calculations, impacts by the highest energy blocks are likely to be mitigated by the tendency toward shoulder impacts rather than crown impacts and by the irregular block shape, wherein the center of mass is not directly over the impact point.

- Dents formed are not expected to result in SCCs penetrating the drip shield due to stress relaxation and low temperature creep of titanium.

- The size of the dent is small relative to the surface area of the drip shield (Section C.2.4).

- If SCCs are initiated, they are not predicted to be through-going in the bottom of dents where seepage water would be captured for penetration. 
- If a through-going crack were initiated in the drip shield, the probability that the drip shield dent/crack is aligned with water dripping from the drift crown is significantly less than one.

- If SCCs are initiated, the small aperture and presence of capillary forces within the crack will limit the amount of advective water flow.

- If SCCs are initiated, plugging of the cracks due to mineral deposits will limit the amount of advective water flow.

Advection of liquids and solids through cracks in the drip shield is excluded on the basis of low consequence because stress corrosion cracks resulting from seismic-induced rockfall are generally not expected to penetrate the drip shield. Even if cracks were to occur, additional factors that will limit the amount of advective water flow through cracks include (1) the small aperture width (narrow opening and tight cracks) and the presence of capillary forces within the SCCs, and (2) the potential for plugging of the cracks due to mineral deposits. A separate FEP, Stress Corrosion Cracking (SCC) of Drip Shields, is excluded on low consequence (FEP 2.1.03.02.0B; BSC 2005 [DIRS 174995], Section 6.2.5).

During a seismic event, rockfall is predicted to occur in the nonlithophysal units as discussed in Drift Degradation Analysis (BSC 2004 [DIRS 166107], Section 6.3). In the lithophysal units, a seismic event results in stress-controlled raveling of small rock fragments (BSC 2004 [DIRS 166107], Sections 6.4.3 and B.1). Approximately 85\% of the repository emplacement area will be in lithophysal rocks (BSC 2004 [DIRS 168370], Table 8). Therefore, approximately $85 \%$ of the drip shields will not be subject to denting from rockfall. Some of the rock blocks ejected from the walls or back of the emplacement drifts in the nonlithophysal units will impact the drip shield and could result in mechanically stressed areas. If the stress is sufficiently high, the damaged area will be susceptible to stress corrosion cracking (BSC 2004 [DIRS 172203], Section 6.2.1). Appendix $\mathrm{C}$ of the current report evaluates the potential for damage to occur to the drip shield relative to its performance as a barrier to seepage contacting the waste packages. The analysis in Appendix $\mathrm{C}$ is designed to estimate the rockfall events that could result in such dents as a function of seismic event probabilities.

In response to stresses induced by rockfall deformations, stress relief via creep mechanisms or stress corrosion cracking of the drip shield may occur. Such cracks in passive alloys such as Titanium Grade 7 tend to be tight (i.e., small crack-opening displacement), as discussed in Stress Corrosion Cracking of the Drip Shield, the Waste Package Outer Barrier, and the Stainless Steel Structural Material (BSC 2004 [DIRS 172203], Section 6.3.7). Typical calculated drip shield SCC apertures are on the order of $200 \mu \mathrm{m}$ or less (BSC 2004 [DIRS 172203], Section 6.3.7). In addition, the cracks in Alloy 22 are rough and tortuous (BSC 2004 [DIRS 172203], Section B6.1), and their opening area varies due to the variation in stress state (BSC 2004 [DIRS 172203], Section 6.5.2, Equation 28). It is expected that stress corrosion cracking morphology in Titanium Grade 7 is similar to that in Alloy 22 because of the crystalline granular structure of these alloys.

If rockfall were to cause plastic deformation of the drip shield, or dents, the consequence to the drip shield's ability to protect waste packages from seepage is a function of whether or not 
cracks are associated with the dents. Unlike most metals and alloys, titanium and many of its alloys are susceptible to creep at lower temperatures down to room temperature (ASM 1961 [DIRS 170284], pp. 537 to 539; Gordon 2005 [DIRS 173726]). Since stress relaxation is directly related to creep, relaxation of rockfall-induced residual stresses is expected and has been measured for titanium and titanium alloys. For example, titanium exhibits significant room temperature stress relaxation even after five minutes when held at a range of stresses from less than half of yield to stresses in excess of the yield strength (Sargent and Conrad 1969 [DIRS 174054], Figure 3). Thus, even though near yield strength residual stresses are calculated to be present following large rockfalls, these displacement-controlled stresses are expected to relax over time to stresses near or below the stress corrosion crack initiation threshold of $50 \%$ of yield strength without initiation of cracking.

This expectation is best corroborated by tests conducted on 182 U-bend test specimens of Titanium Grade 7 and 16 and welded Titanium Grade 12, as discussed in an article by Fix et al. (2004 [DIRS 169321], Results and Discussion Section). Stress corrosion cracking initiation was not detected in any of the Titanium Grade 7 and 16 specimens. In all, only three of the welded Titanium Grade 12 specimens demonstrated cracking. The exposure time was approximately 5 years for Titanium Grade 12 and Titanium Grade 16 and approximately 2.5 years for Titanium Grade 7 (Fix et al. 2004 [DIRS 169321], Experimental Section). Approximately half the specimens were exposed to liquid and half to vapor and a range of relevant environments at 60 and $90^{\circ} \mathrm{C}$. These U-bend specimens were bent approximately 180 degrees and then the legs were restrained to give an apex strain (cold-work level) of approximately $12 \%$. This would have created stress levels near or somewhat above the yield strength.

The plastic deformation associated with the dented regions caused by rockfall will create residual stress gradients in the dented regions. An analysis of the resultant residual stress states is evaluated in Drip Shield Structural Response to Rock Fall Supplemental Calculation (BSC 2005 [DIRS 174052]). An evaluation of the time histories associated with these impacts shows that the stresses decrease as the material rebounds from the impact. The largest block leaves a residual first principal stress of $140 \mathrm{MPa}$ on the outer surface (also referred to as "upper" surface) of the drip shield and a residual first principal stress of $10 \mathrm{MPa}$ on the inner surface (also referred to as "lower" surface) of the drip shield (BSC 2005 [DIRS 174052], Figure 7-60 and Table 7-9). The smaller block leaves a residual first principal stress of $125 \mathrm{MPa}$ on the upper surface of the drip shield and a residual first principal stress of $15 \mathrm{MPa}$ on the lower surface of the drip shield (BSC 2005 [DIRS 174052], Figure 7-57 and Table 7-9).

These residual stress states are well below the 209-MPa yield strength of titanium (BSC 2005 [DIRS 174052], Table 7-9). Since the outer surface of the drip shield exceeds the stress corrosion crack initiation threshold of $50 \%$ of yield strength, it is expected that cracks could initiate within the bottom of dents. However, the inner surface of the drip shield is well below $50 \%$ of the yield strength, so any cracks initiated on the outer surface of the drip shield will not propagate through-wall. Because of creep and stress relief associated with Titanium Grade 7 discussed above, it is logical to expect that these residual stresses will experience stress relief as opposed to cracking to mitigate these residual first principal stresses.

An analogue to the residual stress states and profiles from the stress calculation (BSC 2005 [DIRS 174052], Section 7) were created in stainless steel plates to evaluate the potential for such 
stresses to propagate through-wall cracks. A series of stress corrosion crack tests were performed in which a simulated, rockfall-dented stainless steel plate was exposed to boiling magnesium chloride. This is an environment that will initiate and propagate stress corrosion cracks in stainless steels even at low levels of residual tensile stress down to about $70 \mathrm{MPa}$ (approximately $10 \mathrm{ksi}$ ) (ASM International 1987 [DIRS 101992], p. 272, Figure 54). The stress state in stainless steel was tested as an analogue to that of Titanium Grade 7 since Titanium Grade 7 is extremely resistant to stress corrosion cracking, which is difficult to initiate on this material under test conditions.

A series of tests was conducted to examine the potential for water flow through cracks (DTN: SN0506F4104405.003 [DIRS 174472]). These tests were designed to determine if water could penetrate cracks formed in a stainless steel plate, as well as smooth-walled apertures formed in machined Titanium Grade 7 and stainless steel blocks. The machined-block cracks were created by clamping two blocks together with pieces of shim stock separating the blocks at the desired apertures. Water was dripped onto plates containing cracks from a height of $2.2 \mathrm{~m}$ (the distance from the top of the drip shield to the top of the drift wall), and $0.4 \mathrm{~m}$ (the distance between the drip shield and waste package). The plates were held at different angles relative to the dripping water. A "sheet flow" test was also performed in which the water was applied directly to the plates above the cracks and the water was allowed to flow over the cracks as a "film" or "sheet" flow. The tests are summarized in Analyses of Phase I and Phase II Data from The Stress Corrosion Crack Flow Tests (Data from 1/12/05 to 5/13/05) (DTN: SN0506F4104405.003 [DIRS 174472], SCC_PhaseII_Test_Preliminary_Summary_6-805.doc). The largest aperture used for the titanium blocks was $50.8 \mu \mathrm{m}$. For this aperture, less than $3 \%$ of water penetrated the crack when dripped from a height of $2.2 \mathrm{~m}$ directly onto the crack. The sheet flow test did not yield any penetration through a $50.8 \mu \mathrm{m}$ smooth-walled crack. The results support the conclusion that only a small fraction of seepage flow is likely to penetrate cracks in the drift environment, even if the crack maintains its morphology (i.e., is not plugged), and even if the water directly contacts the cracks. Within the drift, dripping is not likely to coincide exactly with the locations of cracks in the drip shield. Furthermore, it is reasonable to assume that SCCs will exist in a range of sizes. These tests can be considered bounding for cracks up to $50.8 \mu \mathrm{m}$, because the cracks used in the tests did not have the tortuous profiles expected from actual SCCs. It can also be expected that these flow rates will decrease as a result of the plugging mechanisms discussed below.

An analysis of water holding capacity for idealized parallel-plate geometry in Water Distribution and Removal Model (BSC 2001 [DIRS 152016], Table 6-1) shows that for a drip shield wall thickness of $15 \mathrm{~mm}$, the maximum smooth-wall aperture for retention of liquid water is approximately $1 \mathrm{~mm}$ based on a contact angle of $180^{\circ}$. Smaller apertures such as those produced by SCCs have even greater holding capacity that effectively resists advective liquid flow because SCCs for alloys are tight, rough, and tortuous, which limits the transient response to dripping water (BSC 2004 [DIRS 172203], Section B6.1). Small-aperture SCCs readily fill with water, but do not readily flow unless sufficient hydraulic head is applied to overcome surface tension forces.

Eventually, SCCs become plugged as a result of precipitation from seepage, accumulation of corrosion products, and the accumulation of other solid debris. A calculation of the expected rate of SCC plugging due to calcite precipitation has been performed and is documented in 
Plugging of Stress Corrosion Cracks by Precipitation (BSC 2001 [DIRS 156807], Section 6.3). The calculation conservatively assumes that the corrosion products generated on the crack faces, as well as colloids, particulates, and any precipitated minerals, do not help in resisting the water flow, and that there is a uniform water seepage flow in space and time. It is concluded that, under these assumptions, the cracks will be sealed in a few hundred years at most when water is allowed flow at low film-flow rates. If the cracks are bridged by water, plugging may take thousands of years (limited by the delivery of solute), but no flow occurs as capillary forces hold the water. In a more realistic case of non-uniform flow onto the drip shield, more precipitation and faster plugging will occur (BSC 2001 [DIRS 156807], Section 6.3).

The predicted probability of a scenario of seismic-induced rockfall causing damage to a drip shield that could allow seepage to penetrate the drip shield is small. The expectation that SCCs would develop through-wall to the drip shield is low. Taken in aggregate, the predicted consequences of any localized corrosion on a waste package are small. As shown in Appendix C, there are no blocks at the $1.05 \mathrm{~m} / \mathrm{s}$ and $2.44 \mathrm{~m} / \mathrm{s}$ PGV levels that cause a significant dent to form on the drip shield. For blocks simulated using seismic events with PGV levels greater than $2.44 \mathrm{~m} / \mathrm{s}$, their annual probability was shown to be low considering the significant conservatisms in the probability calculation (Appendix C). If rockfall were to cause plastic deformation of the drip shield, or dents, the consequence to the drip shield's ability to protect waste packages from seepage is a function of whether or not cracks are associated with the dents. Unlike most metals and alloys, titanium is susceptible to creep at room temperature and below (as described above). Since stress relaxation is directly related to creep, relaxation of rockfall-induced residual stresses is expected, and these displacement-controlled stresses are expected to relax over time to stresses near or below the stress corrosion crack initiation threshold of $50 \%$ of the yield strength.

The combination of few damaging rockfall events, creep/stress relaxation in drip shield dented areas, capillary effects, evaporation, and plugging significantly limit the amount of seepage water that can flow through cracks in the drip shields. Therefore, the exclusion of the advection of liquid and solids through the drip shield from the TSPA-LA will have an insignificant effect on the magnitude and time of the resulting radiological exposures to the RMEI or radionuclide releases to the accessible environment. Therefore, this FEP, in conjunction with FEP 2.1.03.02.0B in Screening of Features, Events, and Processes in Drip Shield and Waste Package Degradation (BSC 2005 [DIRS 174995], Section 6.2.5), is excluded based on । low consequence.

TSPA Disposition:

N/A

\section{Supporting Documents:}

N/A 


\subsubsection{Microbial Activity in EBS}

FEP Number:

2.1.10.01.0A

FEP Description: Biological activity is important to consider because of the potential impact on aqueous chemical conditions within the waste and EBS. In deep subsurface environments, biological activity is limited to microbiological activity and may include effects of natural and anthropogenic bacteria (e.g., anaerobic, methanogenic, sulfate reducers, etc.), protozoans, yeast, viruses, and algae. This FEP addresses a broad range of effects of biological impacts, including the effects of microbes on corrosion of waste packages, cladding, and waste form; bioreduction of multivalent contaminants, metals, and sulfate; generation of organic complexants and gases as metabolic by-products; and the formation of biofilms and their impact on transport.

\section{Screening Decision:}

Excluded (Low Consequence)

Screening Argument: Evaluation of Potential Impacts of Microbial Activities on Drift Chemistry (BSC 2004 [DIRS 169991]) provides a thorough analysis of in-drift biological activities and their potential impacts on EBS materials and processes. The discussion presented here is based on Sections 6.4, 6.5, and 7.1 of that report (BSC 2004 [DIRS 169991]). This analysis focuses on the drift environment. Environmental constraints on microbial activities are evaluated with respect to their impacts on the in-drift chemical environment in the TSPA-LA. Microbially influenced corrosion (MIC) of the waste packages and drip shields is addressed separately in Screening of Features, Events, and Processes in Drip Shield and Waste Package Degradation (BSC 2005 [DIRS 174995], Sections 6.2.10 and 6.2.11, FEPs 2.1.03.05.0A and 2.1.03.05.0B, respectively). MIC of the cladding is addressed in Clad Degradation - FEPs Screening Arguments (BSC 2004 [DIRS 170019], FEP 2.1.02.14.0A).

Evaluation of Potential Impacts of Microbial Activities on Drift Chemistry (BSC 2004 [DIRS 169991], Section 6.4) describes the physical and chemical repository environment as documented in other project products, and systematically evaluates the environmental constraints on microbial activities. The following conclusions are summarized in Section 7.1 of that report (BSC 2004 [DIRS 169991]), and relate to factors that limit microbial growth under Yucca Mountain repository conditions.

The following environmental factors will severely limit microbial activities in the repository:

- The in-drift temperatures during the thermal pulse created by radioactive decay will exceed the temperature tolerance of all known microbes in the repository environment for a significant portion of the repository time, thus exerting a sterilization effect on microorganisms.

- An oxic environment will prevail in the repository over the growth-permissive period and therefore prevent the generation and accumulation of reduced inorganic species that are the prerequisite for autotrophic metabolism. 
- Microbial incubation experiments have demonstrated that water availability is the primary limiting factor for Yucca Mountain microbial growth. The relative humidity and the liquid-water saturation degree in the repository are predicted to be low, thus further limiting microbial activities.

- Evaporation of seepage waters in the low relative humidity environment will result in brine solutions in which only a few halophiles may be able to survive.

- Phosphate and organic carbon are important limiting factors for Yucca Mountain microbial growth. The extremely low organic carbon supply in the repository will limit heterotrophic microbial activities.

- Because of elevated temperatures, radiation fields, low humidity, and low nutrient supplies, the formation of biofilm in the drift is unlikely.

- Conditions in the repository will limit, if not completely prevent, microbially influenced corrosion.

Because of these limitations on microbial growth, there will be no significant effect resulting from bioreduction of multivalent contaminants, metals, or sulfate, nor will there be any significant potential to form organic complexants.

Evaluation of Potential Impacts of Microbial Activities on Drift Chemistry (BSC 2004 [DIRS 169991], Section 6.5) systematically evaluates the potential impacts on repository chemistry, given the limitations of microbial activity. The report concludes that the effects on water chemistry are negligible (BSC 2004 [DIRS 169991], Section 6.5.1). Although microorganisms may release chemicals that complex with radionuclides, either the concentrations of complexing agents are small, or their binding sites will be dominated by iron ions, or both (BSC 2004 [DIRS 169991], Section 6.5.2). Section 6.5.3 of Evaluation of Potential Impacts of Microbial Activities on Drift Chemistry (BSC 2004 [DIRS 169991]) concludes that potential effects on radionuclide solubility are negligible, while Section 6.5.4 examines the potential for enhanced transport by radionuclides binding directly to the surface of unattached bacteria, concluding that long-distance biocolloid transport is unlikely in a UZ.

Due to the aforementioned environmental constraints, the microbial activity in the repository is expected to be low, and its impacts on drift chemistry will be insignificant. Therefore, FEP 2.1.10.01.0A is excluded from consideration of impacts to the in-drift chemical environment in the TSPA-LA on the basis of low consequence. Its exclusion from the TSPA-LA will not have a significant effect on the magnitude and time of the resulting radiological exposures to the RMEI or radionuclide releases to the accessible environment. This FEP does not address the influence of microbial activity on general corrosion of the outer barrier of the waste package. Microbially induced corrosion of the waste package is addressed in FEP 2.1.03.05.0A in Screening of Features, Events, and Processes in Drip Shield and Waste Package Degradation (BSC 2005 [DIRS 174995], Section 6.2.10).

Thermal effects on chemistry and microbial activity are discussed in Section 6.2 .70 of the present report under FEP 2.1.11.08.0A, as well as in Waste-Form Features Events and Processes 
(BSC 2004 [DIRS 170020], Section 6.2.33). Gas generation from microbial degradation is discussed in Section 6.2.77 of the present report under FEP 2.1.12.04.0A and also in Waste-Form Features Events and Processes (BSC 2004 [DIRS 170020], Section 6.2.35). Radiological mutation of microbes is discussed in Section 6.2.83 of the present report under FEP 2.1.13.03.0A.

TSPA Disposition:

N/A

Supporting Documents:

$\mathrm{N} / \mathrm{A}$

\subsubsection{Heat Generation in EBS}

\section{FEP Number:}

2.1.11.01.0A

FEP Description: Temperature in the waste and EBS will vary through time. Heat from radioactive decay will be the primary cause of temperature change, but other factors to be considered in determining the temperature history include the in-situ geothermal gradient, thermal properties of the rock, EBS, and waste materials, hydrological effects, and the possibility of exothermic reactions. Considerations of the heat generated by radioactive decay should take different properties of different waste types, including DSNF, into account.

\section{Screening Decision:}

Included

\section{Screening Argument: N/A}

TSPA Disposition: The temperature-time history of the waste and EBS is calculated as part of the model described in Multiscale Thermohydrologic Model (BSC 2005 [DIRS 173944]). The temperatures as predicted by the multiscale thermohydrologic model are influenced by not only the heat of radionuclide decay, but also the geothermal gradient from the water table to the ground surface (BSC 2005 [DIRS 173944], Section 6.2.5), and the thermophysical properties of the rock, air, and EBS components. The eight different waste packages considered in MSTHM calculations are summarized in Table 6.3-13 of the accompanying report (BSC 2005 [DIRS 173944]). The report also summarizes the impact of heat generation variability on peak temperatures (BSC 2005 [DIRS 173944], Table 6.3-14), as well as the impact of this variability on the time when boiling at the drift wall ceases (BSC 2005 [DIRS 173944], Table 6.3-15). The different waste packages fall in two major categories: commercial spent nuclear fuel (CSNF) waste packages, which include pressurized-water-reactor (PWR) and boiling-water-reactor (BWR) waste packages, and DHLW waste packages and HLW waste packages. Temperatures for different types of waste forms are captured in a submodel of the MSTHM. These waste forms include the 21-PWR, the DHLW long and short, and the 44-BWR waste forms, all of which produce heat at different rates. These effects are captured in the TSPA-LA by providing the temperatures as direct inputs. Multiscale Thermohydrologic Model (BSC 2005 
[DIRS 173944], Section 6.3.1.2) investigates the influence of waste package-to-waste package heat-generation variability on thermohydrologic conditions in the emplacement drifts.

In-Drift Natural Convection and Condensation (BSC 2004 [DIRS 164327], Section 4.1 .2 and Table 4.1.2-4) also deals with heat generation in the waste packages, which is a function of time and waste package type. The convection and condensation model includes the spatial and temporal variation of the individual waste package power as a function of time. The feed to TSPA-LA through the convection model is indirect because it is through the average equivalent thermal conductivity correlation used by the MSTHM, which considers the variation in waste package, drip shield, and drift wall temperatures that are a function of waste package type and time. The convection and condensation model also calculates a dispersion coefficient that includes heat generation for use in predicting condensation rates throughout the EBS. Condensation forming on the roof or other parts of the drift is fed to TSPA-LA as described in Section 6.2.35 of the present report under FEP 2.1.08.04.0A.

Heat generation in the EBS as applied in the convection and condensation model and in the MSTHM is closely coupled with heat transfer mechanisms. Conservation of energy dictates that all heat generated within the repository during postclosure must leave through the drift wall. Therefore, the temperature on the interior drift wall is dictated by the requirement to dissipate all the heat generated within the repository. The same energy balance applies to heat generated under the drip shield, which must be transferred from the drip shield to the drift wall. In fact, the temperatures on the surfaces of the waste packages, drip shields, and drift walls are all dependent on the heat transfer mechanisms available to satisfy conservation of energy. Heat transfer by conduction, turbulent natural convection, and thermal radiation are all included in the convection and condensation model such that each physical process occurring in the drift cavity during repository operation is modeled. The equivalent thermal conductivity, which is calculated in the convection and condensation model and fed to the MSTHM, does not include radiation because radiation is already included in the MSTHM. Heat transfer mechanisms are described in Sections 6.1.5.1 and 6.4.1.1 of In-Drift Natural Convection and Condensation (BSC 2004 [DIRS 164327]) and in Section 6.2.8.5 of Multiscale Thermohydrologic Model (BSC 2005 [DIRS 173944]).

The preclosure ventilation period for the TSPA-LA design is 50 years, as discussed in Subsurface Facility Description Document (BSC 2005 [DIRS 174514], Section 4.1.1.3). During that time, a substantial amount of the decay heat generated by the waste packages is removed by the ventilation system. The balance of the heat is transferred into the rock. Ventilation efficiency is calculated in Ventilation Model and Analysis Report (BSC 2004 [DIRS 169862], Section 6.3.5). The powers used by the MSTHM and the convection and condensation model are modified by multiplying them by the complement of the ventilation efficiency over the 50 -year ventilation period.

In-drift temperature is also a model input to Engineered Barrier System: Physical and Chemical Environment (BSC 2005 [DIRS 175083], Section 6.7.3). Within the TSPA-LA model, temperature and relative humidity conditions derived from Multiscale Thermohydrologic Model (BSC 2005 [DIRS 173944]) are used to define the environmental conditions on the lookup tables (BSC 2005 [DIRS 175083], Section 6.9.4) so that the chemistry can be determined through time. 
Exothermic reactions are addressed in Section 6.2.68 of the present report under FEP 2.1.11.03.0A.

\section{Supporting Documents:}

BSC 2005 [DIRS 173944]

BSC 2004 [DIRS 169862] (While FEP 2.1.11.01.0A is not explicitly listed in the included FEP table of this supporting document, the FEP is addressed in the current report)

BSC 2004 [DIRS 164327]

\subsubsection{Non-Uniform Heat Distribution in EBS}

\section{FEP Number:}

2.1.11.02.0A

FEP Description: Uneven heating and cooling at edges of the repository may lead to non-uniform thermal effects during both the thermal peak and the cool-down period.

\section{Screening Decision:}

Included

\section{Screening Argument: \\ N/A}

TSPA Disposition: The calculation of the repository thermohydrologic environment, including thermal gradients from the repository center to the edges and corners of the repository, is described in Multiscale Thermohydrologic Model (BSC 2005 [DIRS 173944]). The increase in temperature from the ambient geothermal temperature as predicted by the MSTHM is influenced by: 1) the thermophysical properties of the rock and EBS components, and 2) the repository footprint shape, which influences the evolution of the edge-cooling effect (BSC 2005 [DIRS 173944], Section 1).

Multiscale Thermohydrologic Model (BSC 2005 [DIRS 173944], Table 1-1) provides postclosure thermal and relative humidity conditions to TSPA-LA as functions of time and position.

In-Drift Natural Convection and Condensation (BSC 2004 [DIRS 164327], Section 6.3.5.1.2) also includes the effects of heating and cooling at the repository edges. The calculated temperature profiles reflect the lower temperatures at the repository edge as well as the lower temperatures near the unheated regions in the interior of the repository layout (BSC 2004 [DIRS 164327], Section 6.3.3.1).

The feed to TSPA-LA through the convection model is through the average equivalent thermal conductivity correlation used by the MSTHM. The convection and condensation model also calculates a dispersion coefficient that includes the effects of heating and cooling at the repository edges for use in predicting condensation rates throughout the EBS. Condensation forming on the roof or other parts of the drift is fed to TSPA-LA as described in Sections 6.2.35 and 6.2.36 of the present report under FEPs 2.1.08.04.0A and 2.1.08.04.0B, respectively. 


\section{Supporting Documents:}

BSC 2005 [DIRS 173944]

BSC 2004 [DIRS 164327]

\subsubsection{Exothermic Reactions in the EBS}

\section{FEP Number:}

\subsection{A}

FEP Description: Exothermic reactions liberate heat and will alter the temperature of the disposal system and affect the properties of the repository and surrounding materials. Examples of possible exothermic reactions include oxidation of uranium metal fuels such as represented by $\mathrm{N}$-Reactor fuels and hydration of concrete used in the underground environment.

\section{Screening Decision:}

Excluded (Low Consequence)

Screening Argument: FEP 2.1.11.03.0A, Exothermic Reactions in the EBS, is shared with Waste-Form Features, Events, and Processes (BSC 2004 [DIRS 170020], Section 6.2.32). Exothermic reactions, and other thermal reactions, that liberate heat in the waste and EBS are excluded from the TSPA-LA because the possible temperature rise in a waste package from an exothermic degradation of waste such as N Reactor uranium metal in DSNF, or in the EBS from the hydration of concrete, is negligible in comparison to the substantial heat generated by radioactive decay. The energy released from the oxidation of the uranium metal in a codisposal waste package with N-Reactor fuel was found to be $5.29 \times 10^{7} \mathrm{~kJ} /$ package over the life of the package (BSC 2001 [DIRS 171508], Section 5.2.6). This value is only $3 \%$ of $1.62 \times 10^{9} \mathrm{~kJ}$, which is the heat generation over the first year of emplacement due to radioactive decay in a segment of the repository containing seven waste packages $\left(1.62 \times 10^{9} \mathrm{~kJ}=5.12 \mathrm{E}+01 \mathrm{~kW}\right.$ $($ BSC 2005 [DIRS 173705], Table 1) $\times 3600 \mathrm{~s} / \mathrm{hr} \times 24 \mathrm{hr} /$ day $\times 365.25 \mathrm{day} / \mathrm{yr})$. The seven package segment of the repository is used because it represents the heat output from each of the seven types of waste packages presented in the referenced information exchange drawing (IED) (BSC 2005 [DIRS 173705], Table 1). This comparison is intended only to show the relative magnitude of heat caused by the oxidation reaction for uranium compared with the total heat generation typical of the waste packages as a whole. The IED (BSC 2005 [DIRS 173705], Table 1) gives annual waste package decay heat generation for a period of 1,000,000 years. It is clear that on the time scale of even a few years, the heat generated through the oxidation of uranium is insignificant compared to the total heat generated through radioactive decay.

In addition, the conservative degradation rates used for DSNF already bound any additional thermally induced degradation effects that might result from exothermic reactions in the DSNF (BSC 2004 [DIRS 170020], Section 6.2.5, FEP 2.1.02.01.0A). Because there is no temperature dependence in the recommended upper-limit DSNF model and because the degradation model involves complete degradation within the first time step after contact by water (BSC 2004 [DIRS 172453], Table 6-2), an increase in degradation rate due to temperature increase will have no impact on dose calculations. Note as well that the related effects of pyrophoric reactions are also excluded (BSC 2004 [DIRS 170020], Section 6.2.12, FEP 2.1.02.08.0A). 
In a similar calculation that corroborates the findings above, the heat of reaction by oxidizing all $\mathrm{N}$-Reactor fuel uranium metal is roughly 1/100th the heat energy produced in one year by all DSNF and HLW (DOE 1998 [DIRS 122980], Section ES.3.4). The quantity of DSNF and HLW amount to approximately 7,000 MTHM, or one-tenth of the total repository mass of 70,000 MTHM, as described in Project Requirements Document (Canori and Leitner 2003 [DIRS 166275]), p. 3-95). As shown in IED Subsurface Facilities Committed Materials [Sheet 1 of 1] (BSC 2005 [DIRS 173871]) and Repository Subsurface Emplacement Drifts Steel Invert Structure Sect. \& Committed Materials (BSC 2004 [DIRS 169776]), cementitious materials are not planned for use in the emplacement drifts, so exothermic reactions from hydration of concrete will not have a significant impact on emplacement drift thermal conditions

In summary, omission of exothermic reactions in EBS from the TSPA-LA will not have a significant effect on the magnitude and time of the resulting radiological exposures to the RMEI or radionuclide releases to the accessible environment.

TSPA Disposition:

N/A

Supporting Documents:

$\mathrm{N} / \mathrm{A}$

\subsubsection{Thermal Expansion/Stress of In-Drift EBS Components}

\section{FEP Number:}

2.1.11.07.0A

FEP Description: Repository heat at Yucca Mountain could result in thermally induced stress changes that would affect the mechanical and chemical evolution of the repository. These stress changes could affect the EBS components, thus causing the formation of pathways for groundwater flow through the EBS or altering and/or enhancing existing pathways. Relevant processes include changes in physical properties of the drip shields, waste packages, pallet, and invert.

\section{Screening Decision:}

Excluded (Low Consequence)

Screening Argument: FEP 2.1.11.07.0A, Thermal Expansion/Stress of In-Drift EBS Components, is shared with Screening of Features, Events, and Processes in Drip Shield and Waste Package Degradation (BSC 2005 [DIRS 174995], Section 6.2.29). The coefficient of thermal expansion for Stainless Steel Type 316L (an analogue for the Stainless Steel Type 316 used for the waste package inner vessel) is larger than the coefficient of thermal expansion for Alloy $22\left(316 \mathrm{NG}\right.$ [nuclear grade]: $17 \times 10^{-6} \mathrm{~m} / \mathrm{m} \cdot \mathrm{K}$ at $260^{\circ} \mathrm{C}$; Alloy $22: 12.6 \times 10^{-6} \mathrm{~m} / \mathrm{m} \cdot \mathrm{K}$ from $24^{\circ} \mathrm{C}$ to $316^{\circ} \mathrm{C} ; K=$ temperature in Kelvin (BSC 2001 [DIRS 152655], Section 5.1)). Thus, changes in temperature could lead to contact stresses between the waste package barriers.

In the calculation presented in Waste Package Outer Barrier Stresses Due to Thermal Expansion with Various Barrier Gap Sizes (BSC 2001 [DIRS 152655]), the maximum tangential stress at the waste package outer barrier surfaces (inner and outer) was evaluated for several waste 
package types (21-PWR, 44-BWR, 12-PWR Long, 5 DHLW/DOE SNF-Short, 2-MCO/2-DHLW, and Naval SNF Long) as a function of temperature and barrier gap size (difference in radius of the two barriers) (BSC 2001 [DIRS 152655], Section 5.3). An earlier calculation (BSC 2001 [DIRS 154004], Section 5.3), using a barrier gap size of zero, showed that under thermal expansion, loading tangential stresses are significantly higher than radial stresses (BSC 2001 [DIRS 152655], Section 1). The conclusion of these studies was that a barrier gap size of at least $1 \mathrm{~mm}$ would result in no tangential stresses due to thermal expansion. Current waste package designs require the barrier gap size to be at least $1 \mathrm{~mm}$, as shown in IED Waste Package Processes, Ground Motion Time Histories, and Testing and Materials [Sheet 1 of 1] (BSC 2005 [DIRS 173627]). The waste package pallet also contains components composed of Stainless Steel Type 316L and Alloy 22, as shown in Subsurface Facility Description Document (BSC 2005 [DIRS 174514], Figure 4-7), and thermal expansion of the pallet would have negligible effect because it is not constrained laterally or longitudinally (BSC 2005 [DIRS 174514], Figure 4-10).

Waste Package Operation Fabrication Process Report (Plinski 2001 [DIRS 156800], Section 8.1.8) requires a loose fit between the outer barrier (Alloy 22) and the inner vessel (Stainless Steel Type 316) to accommodate the differing thermal expansion coefficients. Current waste package designs also require large longitudinal barrier gaps (lid to outer lid gap of $11.1 \mathrm{~mm}$ ), as shown in 21-PWR Waste Package Configuration (BSC 2004 [DIRS 170710]; BSC 2005 [DIRS 173501], Table 1). Therefore, although thermal expansion of waste package components does occur, no significant stresses due to differing thermal expansion between the barriers develop (outer barrier stresses due to thermal expansion were analyzed for a temperature range of $20^{\circ} \mathrm{C}$ to $239^{\circ} \mathrm{C}$, as documented in BSC 2001 [DIRS 152655], Section 3.1).

In the current drip shield design (BSC 2003 [DIRS 168067]), the drip shield connectors are designed to have an overlap that allows for thermal expansion with no effect on drip shield performance. The drip shield segments are interlocked with a significant amount of freedom to expand and still maintain their intended purpose. The space between the drip shield and waste package is large enough to accommodate deflection due to rockfall (BSC 2005 [DIRS 174995], Section 6.2.14).

Any thermal expansion of the invert ballast material will not generate appreciable stress because the material is unconstrained vertically and will expand into the open spaces of the drift, as discussed in Section 6.2.22 of the current report under FEP 2.1.06.05.0B. In summary, omission of thermal expansion and associated stress of in-drift EBS components from the TSPA-LA will not have a significant effect on the magnitude and time of the resulting radiological exposures to the RMEI or radionuclide releases to the accessible environment.

\section{TSPA Disposition:}

NA

\section{Supporting Documents:}

N/A 


\subsubsection{Thermal Effects on Chemistry and Microbial Activity in the EBS}

FEP Number:

2.1.11.08.0A

FEP Description: Temperature changes may affect chemical and microbial processes in the waste and EBS.

\section{Screening Decision:}

Included

\section{Screening Argument: \\ N/A}

TSPA Disposition: FEP 2.1.11.08.0A, Thermal Effects on Chemistry and Microbial Activity in the EBS, is shared with Waste-Form Features, Events, and Processes (BSC 2004 [DIRS 170020]), Section 6.2.33). Heat generation in the EBS controls predicted in-drift temperatures in Drift-Scale THC Seepage Model (BSC 2005 [DIRS 172862], Section 6.5.5). In-drift temperature is model input, taken from the THC seepage model at each time step. The effects of temperature on mineral stabilities and chemical reaction rates are implicitly included in each geochemical submodel of Engineered Barrier System: Physical and Chemical Environment (BSC 2005 [DIRS 175083], Sections 6.5.1 and 6.5.3). In geochemical modeling of the water compositions resulting from seepage evaporation (BSC 2005 [DIRS 175083]), Section 6.9), the temperature range over which individual mineral phases are stable is a function of the thermodynamic data used in the modeling. By controlling the stability of some mineral phases, the in-drift temperature directly affects the modeled evolution of the in-drift waters, and hence the water compositions that are passed to total system performance assessment in the form of lookup tables. In addition, temperature will affect reaction kinetics for corrosion of committed materials. This was examined with respect to its effect on in-drift water and atmosphere compositions. Seepage water interactions with rock bolts and Stainless Steel Type 316L mesh in the drift wall is evaluated in Engineered Barrier System: Physical and Chemical Environment (BSC 2005 [DIRS 175083], Section 6.8) and found to be of low consequence.

The model developed in In-Drift Precipitates/Salts Model (BSC 2004 [DIRS 169863]) also addresses this FEP. This model performs in-drift water chemistry calculations that provide detail required for predicting interactions of water chemistry with microbes. The IDPS model lookup table output includes boundary values, abstraction output, and supplemental calculations, as defined in the accompanying report (BSC 2004 [DIRS 169863], Section 6.6.3.5). Boundary values include temperature, the fugacities of carbon dioxide and oxygen, and the reaction progress. Abstraction output includes $\mathrm{pH}$, activity of water, ionic strength, mass of solvent water remaining, total concentrations of each element, concentrations of select aqueous species that potentially contribute to acid-neutralizing capacity, and amounts of solids precipitating in a given EQ6 run. Supplemental calculations include relative humidity, concentration factor, relative evaporation rate, and dilution factor.

Evaluation of Potential Impacts of Microbial Activities on Drift Chemistry (BSC 2004 [DIRS 169991], Section 6.4) provides a thorough discussion of several repository-specific 
environmental constraints on microbial activity. Factors considered include: temperature, pressure, oxic and anoxic conditions, relative humidity, water availability, $\mathrm{pH}$, salinity, nutrient availability, biofilm formation, and radiation effect. The conclusions from that analysis are summarized in Section 6.2.65 of the present report under FEP 2.1.10.01.0A. The evaluation shows that environmental factors will severely limit microbial activities in the repository. In particular, in-drift temperatures during the thermal pulse created by radioactive decay will exceed the temperature tolerance of all known microbes for a significant portion of the repository time, thus exerting a sterilization effect on microorganisms (BSC 2004 [DIRS 169991], Section 7.1). Evaluation of Potential Impacts of Microbial Activities on Drift Chemistry (BSC 2004 [DIRS 169991], Section 7.1) therefore concludes that contributions from microbial activity may be neglected in TSPA-LA dispositions for included FEPs.

\section{Supporting Documents:}

BSC 2005 [DIRS 175083]

BSC 2004 [DIRS 169863]

BSC 2004 [DIRS 169991]

\subsubsection{Thermal Effects on Flow in the EBS}

\section{FEP Number:}

\subsection{A}

FEP Description: High temperatures in the EBS may influence seepage into, and flow within, the waste and EBS. Thermally-induced changes to fluid saturation and/or relative humidity could influence in-package chemistry. Thermal gradients in the repository could lead to localized accumulation of moisture. Wet zones could form below the areas of moisture accumulation.

\section{Screening Decision:}

Included

\section{Screening Argument: N/A}

TSPA Disposition: Multiscale Thermohydrologic Model (BSC 2005 [DIRS 173944]) calculates the thermohydrologic environment within and around the emplacement drifts. Based on the modeling methodology and inputs described in that report (BSC 2005 [DIRS 173944], Sections 6.2 and 4, respectively), the MSTHM predicts the temperature, relative humidity, gasand liquid-phase fluxes, and gas- and liquid-phase saturations in the near-field host rock, as well as within the emplacement drifts (BSC 2005 [DIRS 173944], Section 6.3). These MSTHM outputs indirectly affect the in-drift chemical environment through the TSPA-LA. Abstraction of Drift Seepage (BSC 2004 [DIRS 169131], Section 6.8) describes the probabilistic approach for representing the distribution of seepage into the waste emplacement drifts, including implementation of the abstraction of seepage during the thermal period.

A key thermal-hydrologic parameter is the maximum lateral extent of the boiling zone (zone of two-phase flow) relative to the centerline of the emplacement drifts because this is a strong indication of the likelihood of continuous condensate and percolation-flux drainage around 
emplacement drifts. For the three infiltration-flux data sets considered in the MSTHM, the maximum lateral extent of boiling ranges are calculated. It is important to note that the lateral extent of boiling is always much smaller than the half spacing between emplacement drifts. Therefore, the majority of the host rock between the emplacement drifts always remains below the boiling point, thereby enabling condensate and percolation flux to continuously drain between emplacement drifts.

Conditions calculated by the MSTHM, together with calculations in Abstraction of Drift Seepage (BSC 2004 [DIRS 169131]) and In-Drift Natural Convection and Condensation (BSC 2004 [DIRS 164327], Section 8), are combined in TSPA. The combined information describes flow into drifts, and in the invert, which is used by the EBS flow model described in EBS Radionuclide Transport Abstraction (BSC 2005 [DIRS 173433]). Thus, thermal effects on flow in the EBS are accounted for in the various pathway flow rates used to calculate the advective and diffusive releases of radionuclides.

Thermal gradients in the repository could lead to localized accumulation of moisture within the cooler regions of the emplacement drifts. Such effects are represented in the TSPA-LA by the condensation model developed in In-Drift Natural Convection and Condensation (BSC 2004 [DIRS 164327], Sections 6.3.1 and 6.3.1.1). Condensation on the drift walls is represented in the same manner as drift seepage, although with a different spatial distribution and flux rate (BSC 2004 [DIRS 164327], Section 6.3.1). The abstraction of the condensation model defines the condensation rate and the likelihood of condensation on the drift wall, under the drip shield, and on the waste packages, and the rate of condensation should it occur. The condensation abstraction includes algorithms used in the TSPA-LA for interpolating the condensation rates and probabilities, and specifies how parameters are used in the model and where they are obtained (BSC 2004 [DIRS 164327], Section 8.3.1). As such, it affects the transport of radionuclides through the drift invert and the partitioning of that transport into the fractures and the matrix of the host rock.

The effects of evaporation and condensation are addressed in the present report in Section 6.2.35 (FEP 2.1.08.04.0A), Section 6.2.36 (FEP 2.1.08.04.0B), and Section 6.2.43 (FEP 2.1.08.14.0A).

Supporting Documents:

BSC 2005 [DIRS 173944]

BSC 2005 [DIRS 173433]

BSC 2004 [DIRS 164327]

\subsubsection{Thermally Driven Flow (Convection) in Drifts}

\section{FEP Number:}

2.1.11.09.0C

FEP Description: Temperature differentials may result in convective flow in the EBS. Convective flow within the drifts could influence in-drift chemistry.

\section{Screening Decision:}

Included 


\section{Screening Argument:}

N/A

TSPA Disposition: Heat generated by decaying radioactive waste would result in temperature differences between the waste package and the other components of the drift. These temperature differences cause convection within the open spaces in the drift. In-Drift Natural Convection and Condensation (BSC 2003 [DIRS 164327]) addresses natural convection in the drifts after closure. The effects of natural and forced convection during ventilation are addressed in Ventilation Model and Analysis Report (BSC 2004 [DIRS 169862], Section 8.2).

The model presented in In-Drift Natural Convection and Condensation (BSC 2003 [DIRS 164327], Table 4.1.3-7) deals with heat generation in the waste packages, which is a function of time. An analysis is used to develop an effective thermal conductivity that includes the effects of turbulent natural convection, which is subsequently used in submodels of the MSTHM. Use of the effective thermal conductivity in conduction-only heat flow models that use a porous medium is designed to approximate turbulent natural convection. Using this simplification, the overall heat transfer rate from the waste package to the in-drift components is maintained. The convection and condensation model (BSC 2003 [DIRS 164327] Section 6.3.3.1) also calculates a dispersion coefficient that includes the effects of convection for use in predicting condensation rates throughout the EBS. Condensation forming on the roof or other parts of the drift is input to TSPA-LA as described in Section 6.2.35 of the present report under FEP 2.1.08.04.0A. Condensation forming at the repository edges is discussed in Section 6.2.36 under FEP 2.1.08.04.0B, and condensation forming on the underside of the drip shields is discussed in Section 6.2.43 under FEP 2.1.08.14.0A.

The outputs of models presented in Ventilation Model and Analysis Report (BSC 2004 [DIRS 169862], Section 8.2) and In-Drift Natural Convection and Condensation (BSC 2004 [DIRS 164327], Section 8.3.2) are used in the MSTHM, which generates thermal-hydrologic variables in the drift for use as direct input to TSPA-LA. The MSTHM calculates the following thermal-hydrologic variables: temperature, relative humidity, liquid-phase saturation, evaporation rate, air-mass fraction, gas-phase pressure, capillary pressure, and liquid- and gas-phase fluxes. Condensation forming on the roof or other parts of the drift is input to TSPA-LA as described in Section 6.2.35 of the present report under FEP 2.1.08.04.0A.

Ventilation is discussed in Section 6.2.3 under FEP 1.1.02.02.0A.

\section{Supporting Documents:}

BSC 2004 [DIRS 164327]

\subsubsection{Thermal Effects on Transport in EBS}

\section{FEP Number:}

$$
\text { 2.1.11.10.0A }
$$

FEP Description: Temperature changes in the repository may influence advection, diffusion, and sorption in the EBS. The Soret effect is a diffusion process caused by a thermal gradient. In liquids having both light and heavy molecules (or ions) and a temperature or thermal gradient, the heavier solute molecules tend to concentrate in the colder region. Temperature differences in 
the waste and EBS may result in a component of diffusive solute flux that is proportional to the temperature gradient.

\section{Screening Decision:}

Excluded (Low Consequence)

Screening Argument: The Soret effect is a diffusion process caused by a thermal gradient. Thermal gradients within the repository will be greatest surrounding the thermal pulse, when the maximum thermal response occurs in the repository. Later in time, as the repository cools, the thermal gradients within the EBS will be reduced. In all cases, the Soret effect is considered to be negligible and is not modeled in EBS Radionuclide Transport Abstraction (BSC 2005 [DIRS 173433], Section 6.3.4.1.2). According to Bird et al. (1960 [DIRS 103524], pp. 565 to 567), "The thermal diffusion term [Soret effect] describes the tendency for species to diffuse under the influence of a temperature gradient; this effect is quite small." Hirschfelder et al. (1964 [DIRS 171800], p. 8) state that "Diffusion may also result from a temperature gradient (thermal diffusion or the Soret effect), and the transfer of energy may also result from a concentration gradient (diffusion thermo or Dufour effect). These are small effects."

In EBS Radionuclide Transport Abstraction (BSC 2005 [DIRS 173433], Section 6.3.4.3.5) the diffusion coefficient for the corrosion products and waste form domains is not modified for temperature. This is justified due to the lack of experimental data on which to quantify the uncertainty in the corrosion product and waste form diffusion coefficients. Some uncertainty in the corrosion products diffusion coefficient is accounted for by the dependence on specific surface area squared. This surface area uncertainty parameter ranges from 1.0 to $22 \mathrm{~m}^{2} \mathrm{~g}^{-1}$ (BSC 2005 [DIRS 173433], Sections 6.3.4.3.3 and 6.3.4.3.5); thus the corrosion products diffusion coefficient varies by more than two orders of magnitude due to the uncertainty in specific surface area alone. Without a more precise basis in experimental measurements, further refinements such as the modification for temperature are not justified.

The thermal effect on diffusion coefficients for species in an aqueous medium is based on hydrodynamic theory and is roughly described by the Stokes-Einstein equation (Bird et al. 1960 [DIRS 103524], Section 16.5). The Stokes-Einstein equation shows that the diffusion coefficient in liquid medium is directly proportional to the temperature divided by the viscosity of the medium. For aqueous medium the viscosity of water decreases with respect to increasing temperature so that the diffusion coefficient is seen to increase with increasing temperature. Diffusion in the invert with respect to temperature is further discussed as part of FEPs 2.1.09.08.0A and 2.1.09.24.0A in Sections 6.2.51 and 6.2.58, respectively, of the current report.

An evaluation to determine the potential for sorption coefficients to vary with temperature on substrates (tuff and hematite) relevant to the repository was done as discussed in Abstraction of Drift-Scale Coupled Processes (BSC 2004 [DIRS 169617], Section 6.4). It was concluded that the sorption behavior of the radioelements with temperature can be ignored in modeling radionuclide transport in the near field of the repository (BSC 2004 [DIRS 169617], Section 6.4.4.4). 
Thermal gradients and temperature effects relative to advection are addressed by evaluations of these transport-related processes as summarized in Sections 6.2.52 and 6.2.54 of the current report (FEPs 2.1.09.08.0B and 2.1.09.19.0B, respectively).

Thus, thermal effects on transport in the EBS is of low consequence to repository performance. In summary, omission of this FEP from the TSPA-LA will not have a significant effect on the magnitude and time of the resulting radiological exposures to the RMEI or radionuclide releases to the accessible environment.

TSPA Disposition:

N/A

Supporting Documents:

N/A

\subsubsection{Gas Generation (Repository Pressurization)}

\section{FEP Number:}

2.1.12.01.0A

FEP Description: Gas generation in the repository might lead to pressurization of the repository, produce multiphase flow, and affect radionuclide transport. This FEP addresses repository pressurization.

\section{Screening Decision:}

Excluded (Low Consequence)

Screening Argument: Gas may be generated in the repository by a variety of mechanisms. Waste form decay may result in helium gas production (Section 6.2.75, FEP 2.1.12.02.0A); waste package corrosion may cause hydrogen gas generation (Section 6.2.76, FEP 2.1.12.03.0A); microbial degradation may lead to the generation of gases $\left(\mathrm{CO}_{2}, \mathrm{CH}_{4}, \mathrm{H}_{2} \mathrm{~S}\right)$ (Section 6.2.77, FEP 2.1.12.04.0A); and gas may be generated by radiolysis (Section 6.2.81, FEP 2.1.13.01.0A).

With respect to waste-form contribution to gas generation, gas may be generated in the waste in the waste packages prior to waste-package potential breaching as well as after breaching, allowing any gas to escape to the repository. Gas generation could conceivably lead to pressurization of the waste packages prior to potential waste-package breaching. After the waste packages are breached, gas generation could conceivably lead to pressurization of the repository and affect radionuclide transport.

Gas is not expected to cause repository pressures to increase, given the repository's lithologic setting. As discussed in Drift Degradation Analysis (BSC 2004 [DIRS 166107], Section 6.1.4), the repository is situated in the Topopah Spring Welded Tuff, which is heavily fractured, allowing gases to escape the repository as discussed below.

Drift Scale THC Seepage Model (BSC 2005 [DIRS 172862], Section 6.5) summarizes pressures and gas phase compositions in the drift during the thermal period. The thermal period corresponds to the period during which rock-wall temperatures exceed boiling, and begins when 
forced ventilation is stopped (at 50 years) and persists for about 2,000 years (BSC 2005 [DIRS 175083], Figure 6.7-5). During the thermal period, liquid water in the drift boils, generating water vapor at a rate sufficient to drive the ambient drift air out and reduce oxygen levels by as much as a factor of 10,000, as documented in Engineered Barrier System: Physical and Chemical Environment (BSC 2005 [DIRS 175083], Section 6.7.1 and Figure 6.7-1). Despite the large volume change associated with the phase transition from liquid water to vapor (a factor of $\sim 1600$ at $100^{\circ} \mathrm{C}$ and 1 atmosphere, as given by Keenan et al. 1964 [DIRS 134666]), THC seepage model simulations show that pressures in fractures adjacent to the drift (which are nearly identical to pressures in the drift) do not significantly increase during the boiling period. This is documented in DTN: LB0302DSCPTHCS.002 [DIRS 161976], in spreadsheet "thc6_wn_drift_r.xls" ( $n=0,4,5,6,7$, for different starting waters), on the worksheets titled "fractures-th," in the columns labeled "N," "O," and "P" for the crown, side, and base of the drift.

Additional corroborative evidence for the relative permeability (with respect to gases) of the repository host unit and of the mountain as a whole is presented in Hydrogeology of the Unsaturated Zone, North Ramp Area of the Exploratory Studies Facility, Yucca Mountain, Nevada (Rousseau et al. 1999 [DIRS 102097], p. 55), which describes variations in the pressure of the gas phase in the UZ due to barometric pumping. Changes in gas and water vapor pressures at the repository level are driven by changes in the atmospheric barometric pressure, and are transmitted primarily through the connected fracture network (Rousseau et al. 1999 [DIRS 102097], p. 56).

The results of the THC seepage model simulations and the evidence for barometric pumping indicate that gas generation resulting from microbial respiration, corrosion, radiolysis, and other in-drift processes will not result in repository pressurization. Therefore, omission of drift pressurization from the TSPA-LA will not have a significant effect on the magnitude and time of the resulting radiological exposures to the RMEI or radionuclide releases to the accessible environment.

TSPA Disposition:

N/A

Supporting Documents:

$\mathrm{N} / \mathrm{A}$

\subsubsection{Gas Generation (He) from Waste Form Decay}

\section{FEP Number:}

2.1.12.02.0A

FEP Description: Helium (He) gas production may occur by alpha decay in the waste. Helium production might cause local pressure buildup in cracks in the fuel and in the void between fuel and cladding, leading to cladding and waste package failure.

\section{Screening Decision:}

Excluded (Low Consequence) 
Screening Argument: Helium production is a result of alpha decay of some nuclides, so it is a consequence of the decay process. Helium production could result in earlier failure of CSNF cladding as a result of higher internal gas pressures. Piron and Pelletier (2001 [DIRS 165318], Section 5.3) investigated pressurization of the fuel rods from alpha decay helium production and concluded that fuel with a burn-up of $47.5 \mathrm{mwd} / \mathrm{KgU}$ would produce $1171 \mathrm{~cm}^{3}$ (STP) of helium in a rod after 10,000 years, too low a quantity to damage the fuel. The conclusion reached for this same FEP (2.1.12.02.0A), as described in Clad Degradation - FEPs Screening Arguments (BSC 2004 [DIRS 170019], Section 6.2.23), is that pressurization of cladding will not result in cladding damage. Helium could also accumulate in the waste package, but it can be concluded that internal gas pressures are not large enough to result in waste package damage.

As discussed in Section 6.2.74 of the current report under FEP 2.1.12.01.0A, generation of He and other gases does not result in any impact on repository pressures.

Therefore, omission of helium gas generation (from waste form decay) from the TSPA-LA will not have a significant effect on the magnitude and time of the resulting radiological exposures to the RMEI or radionuclide releases to the accessible environment.

TSPA Disposition:

N/A

Supporting Documents:

$\mathrm{N} / \mathrm{A}$

\subsubsection{Gas Generation $\left(\mathrm{H}_{2}\right)$ from Waste Package Corrosion}

\section{FEP Number:}

2.1.12.03.0A

FEP Description: Gas generation can affect the mechanical behavior of the host rock and engineered barriers, chemical conditions, and fluid flow, and, as a result, the transport of radionuclides. Gas generation due to oxic corrosion of waste packages, cladding, and/or structural materials will occur at early times following closure of the repository. Anoxic corrosion may follow the oxic phase if all oxygen is depleted. The formation of a gas phase around the waste package may exclude oxygen from the iron, thus inhibiting further corrosion.

\section{Screening Decision:}

Excluded (Low Consequence)

Screening Argument: Gas generated from corrosion of metal components within the EBS could conceivably influence in-drift chemistry and fluid flow in the EBS if the generation rate was sufficiently high. The gas generated could contribute to repository pressurization.

Hydrogen can be generated by anoxic corrosion of materials committed to the EBS. Engineered Barrier System: Physical and Chemical Environment (BSC 2005 [DIRS 175083], Section 6.7.1) demonstrates that conditions in the emplacement drifts remain oxic at all times over the life of the repository. There is only a brief period of reduced oxygen levels during the repository boiling period when vapor displaces much of the oxygen from the drift. The primary effect may 
be to cause some hydrogen-induced cracking of the metal structures, but this is only of potential significance to the waste package and drip shield and is addressed by FEPs 2.1.03.04.0A and 2.1.03.04.0B in Screening of Features, Events, and Processes in Drip Shield and Waste Package Degradation (BSC 2005 [DIRS 174995], Sections 6.2.8 and 6.2.9).

Omission of $\mathrm{H}_{2}$ gas generation from metal corrosion will not significantly change the calculated radiological exposures or radionuclide releases for the following reasons. The corrosion rate, whether oxic or anoxic, associated with the drip shield and waste package is very slow compared to the time-scale of interest. Conservative bounding analyses indicate that general corrosion would lead to a loss of about $2.6 \mathrm{~mm}$ of the Alloy 22 waste package outer barrier wall thickness and $0.75 \mathrm{~mm}$ of the drip shield wall thickness in 10,000 years, as discussed in IED Interlocking Drip Shield and Emplacement Pallet [Sheet 1 of 1] (BSC 2005 [DIRS 173303]), General Corrosion and Localized Corrosion of Waste Package Outer Barrier (BSC 2004 [DIRS 169984], Section 8.1), and in Aqueous Corrosion Rates for Waste Package Materials (BSC 2005 [DIRS 169982], p. 6-40). The nominal thickness of the drip shield is $15 \mathrm{~mm}$ (BSC 2005 [DIRS 173303]) and the thickness of the waste package outer barrier is $20 \mathrm{~mm}$ or $25.4 \mathrm{~mm}$ depending on the package type, as shown in IED Waste Package Configuration [Sheet 1 of 1] (BSC 2005 [DIRS 173501], Table 1). The materials selected for the waste package outer barrier and the drip shield are highly corrosion resistant. These materials form a thin, highly protective oxide layer (passive film) that protects them from further corrosion (BSC 2004 [DIRS 169845], Section 6.3.1; BSC 2004 [DIRS 169984], Section 6.4.1). As a result, limited corrosion of these materials leads to negligible gas generation.

The small amount of gas that may be produced due to anoxic corrosion is not expected to cause repository pressures to increase, given the repository's lithologic setting, as discussed in Section 6.2.74 of the present report under FEP 2.1.12.01.0A.

The potential for hydrogen to impact the waste package, cladding, and internal structure of the waste package through chemical processes (hydride cracking) is discussed under this same FEP (2.1.12.03.0A) in Screening of Features, Events, and Processes in Drip Shield and Waste Package Degradation (BSC 2005 [DIRS 174995], Section 6.2.30), and in Clad Degradation FEPs Screening Arguments (BSC 2004 [DIRS 170019], Section 6.2.24). The effects are screened out on the basis of low consequence.

Therefore, omission of hydrogen gas generation (from waste package corrosion) from the TSPA-LA will not have a significant effect on the magnitude and time of the resulting radiological exposures to the RMEI or radionuclide releases to the accessible environment.

TSPA Disposition:

N/A

\section{Supporting Documents:}

N/A 


\subsubsection{Gas Generation $\left(\mathrm{CO}_{2}, \mathrm{CH}_{4}, \mathrm{H}_{2} \mathrm{~S}\right)$ from Microbial Degradation}

\section{FEP Number:}

2.1.12.04.0A

FEP Description: Microbes are known to produce inorganic acids, methane, organic byproducts, carbon dioxide, and other chemical species that could change the longevity of materials in the repository and the transport of radionuclides from the near-field. The rate of microbial gas production will depend on the nature of the microbial populations established, the prevailing conditions (temperature, pressure, geochemical conditions), and the organic or inorganic substrates present. Initial analysis indicates the most important source of nutrient in the YMP repository will be metals. Other possible nutrients include cellulosic material, plastics, and synthetic materials. Minimal amounts of organics are mandated by regulation.

\section{Screening Decision:}

Excluded (Low Consequence)

Screening Argument: FEP 2.1.12.04.0A, Gas Generation $\left(\mathrm{CO}_{2}, \mathrm{CH}_{4}, \mathrm{H}_{2} \mathrm{~S}\right)$ from Microbial Degradation, is shared with Waste-Form Features, Events, and Processes (BSC 2004 [DIRS 170020], Section 6.2.35). Evaluation of Potential Impacts of Microbial Activities on Drift Chemistry (BSC 2004 [DIRS 169991], Section 6.4) provides a thorough discussion of several repository-specific environmental constraints on microbial activity. Factors considered include: temperature, pressure, oxic and anoxic conditions, relative humidity, water availability, $\mathrm{pH}$, salinity, nutrient availability, biofilm formation, and radiation effect. The conclusions from that analysis are summarized in Section 6.2.65 of the present report under FEP 2.1.10.01.0A. The evaluation shows that environmental factors will severely limit microbial activities in the repository.

Evaluation of Potential Impacts of Microbial Activities on Drift Chemistry (BSC 2004 [DIRS 169991], Section 6.5) systematically evaluates the potential impacts on repository chemistry, given the limitations of microbial activity. The report (BSC 2004 [DIRS 169991], Section 6.5.1) discusses the production of $\mathrm{CO}_{2}$ as a metabolic product of heterotrophic degradation of organic carbon. That discussion shows that the release of carbon dioxide could potentially perturb the carbonate equilibrium and, therefore, the $\mathrm{pH}$ in water entering the repository. However, the extent of this perturbation solely depends on the availability of organic carbon, which can derive from two sources: groundwater and introduced materials. Yucca Mountain groundwater contains only a trace concentration of organic carbon $(0.8 \mathrm{mg} / \mathrm{L})$, which is three orders of magnitude lower than the total carbonate concentration in the solution. The introduced materials essentially contain no biodegradable organic carbon. Therefore, even if all the organic carbon is converted to carbon dioxide, the perturbation to the water chemistry is still negligible.

Metabolic products of heterotrophic degradation of organic carbon also include $\mathrm{CH}_{4}$ and $\mathrm{H}_{2} \mathrm{~S}$ (BSC 2004 [DIRS 169991], Section 6.1.3 and Table 6.1-2). The limited amount of carbon, as described above, will preclude the production of these gases in significant quantities. Further, the oxidizing conditions in the repository will tend to minimize $\mathrm{H}_{2} \mathrm{~S}$ quantities (BSC 2004 [DIRS 169991], Section 6.4.2). 
Based on the discussion above, gas generation from microbial degradation will have a negligible impact on drift chemistry. Therefore, FEP 2.1.12.04.0A is excluded from TSPA-LA on the basis of low consequence because its exclusion will not have a significant effect on the magnitude and time of the resulting radiological exposures to the RMEI or radionuclide releases to the accessible environment.

Gas generation (repository pressurization) due to the production of gases such as $\mathrm{CO}_{2}, \mathrm{CH}_{4}$, and $\mathrm{H}_{2} \mathrm{~S}$ is discussed in Section 6.2.74 of the present report under FEP 2.1.12.01.0A.

TSPA Disposition:

N/A

Supporting Documents:

N/A

\subsubsection{Gas Transport in EBS}

FEP Number:

2.1.12.06.0A

FEP Description: Gas in the waste and EBS could affect the long-term performance of the disposal system. Radionuclides may be transported as gases or in gases. Gas bubbles may affect flow paths, and two-phase flow conditions may be important.

\section{Screening Decision:}

Excluded (Low Consequence)

Screening Argument: Several potential sources of gas in the waste package and EBS include: (1) air $\left(\mathrm{O}_{2}, \mathrm{~N}_{2}, \mathrm{CO}_{2}, \mathrm{H}_{2}\right.$, etc.), present at closure and circulated through advection and diffusion during the life of the repository; (2) gases produced from microbial processes $\left(\mathrm{CO}_{2}, \mathrm{CH}_{4}, \mathrm{H}_{2} \mathrm{~S}\right)$ (Section 6.2.77, FEP 2.1.12.04.0A); (3) gases produced from waste form and EBS component degradation; (4) fission product gases ( $\mathrm{Ar}, \mathrm{Xe}, \mathrm{Kr}$ ); (5) helium from initial fuel rod manufacture and waste form decay (Section 6.2.75, FEP 2.1.12.02.0A); (6) $\mathrm{H}_{2}$ from waste package corrosion (Section 6.2.76, FEP 2.1.12.03.0A); and (7) gas generated by radiolysis (Section 6.2.81, FEP 2.1.13.01.0A). The following discussion is in three parts: (1) gas and performance; (2) radioactive gases; and (3) gas bubbles and two-phase flow.

Gas and performance. In general, gases that may be present in the repository or formed from various processes are likely to advect and diffuse into the drift walls, become diluted, and disperse throughout the surrounding rock (gas transport in the geosphere is discussed under FEP 2.2.11.03.0A in BSC 2005 [DIRS 174191], Section 6.7.3). Drift Scale THC Seepage Model (BSC 2005 [DIRS 172862], Section 6.5) summarizes pressures and gas phase compositions in the drift during the thermal period. The thermal period corresponds to the period during which rock-wall temperatures exceed boiling, and begins when forced ventilation is stopped (at 50 years) and persists for about 2,000 years (BSC 2005 [DIRS 175083], Figure 6.7-5). Where the temperature is above the boiling point of water, boiling of pore fluids in the rock generates water vapor at a rate sufficient to dilute the ambient air in the drift, displacing the original gas radially outward from the drifts themselves and imposing a nearly pure $\mathrm{H}_{2} \mathrm{O}$ gas 
phase on the region within the boiling front, as described in Engineered Barrier System: Physical and Chemical Environment (BSC 2005 [DIRS 175083], Section 6.7.1).

Despite the large volume change associated with the phase transition from liquid water to vapor (a factor of 1600), THC seepage model simulations show that pressures in fractures adjacent to the drift (which are nearly identical to pressures in the drift) do not significantly increase during the boiling period. This is documented in DTN: LB0302DSCPTHCS.002 [DIRS 161976], in spreadsheet "thc6_wn_drift_r.xls" ( $n=0,4,5,6,7$, for different starting waters), on the worksheets titled "fractures-th," in the columns labeled "N," "O," and "P" for the crown, side, and base of the drift.

Additional corroborative evidence for the relative permeability with respect to gases of the repository host unit and of the mountain as a whole is presented in Hydrogeology of the Unsaturated Zone, North Ramp Area of the Exploratory Studies Facility, Yucca Mountain, Nevada (Rousseau et al. 1999 [DIRS 102097], p. 55), which describes variations in the pressure of the gas phase in the UZ due to barometric pumping. Changes in gas and water vapor pressures at the repository level are driven by changes in the atmospheric barometric pressure, and are transmitted primarily through the connected fracture network (Rousseau et al. 1999 [DIRS 102097], p. 56).

The results of the THC seepage model simulations and the evidence for barometric pumping indicate that gas generation resulting from microbial respiration, corrosion, radiolysis, and other in-drift processes will not accumulate to the point of having any impact on long-term performance.

With regard to biogenic gases, high early repository temperatures, the primarily oxic environment, and a relative scarcity of water and organic carbon will combine to limit microbial activity in the emplacement drifts, as demonstrated in Evaluation of Potential Impacts of Microbial Activities on Drift Chemistry (BSC 2004 [DIRS 169991], Section 6.4).

Radioactive gases. The isotope ${ }^{14} \mathrm{CO}_{2}$ is unlikely to be present in the drift outside the waste package. ${ }^{14} \mathrm{C}$ is formed from nitrogen in a reactor through neutron capture and proton decay. Neutron flux outside a waste package from decay of waste is sufficiently low that formation of ${ }^{14} \mathrm{C}$ from ambient nitrogen or carbon would be insignificant.

Generation of radioactive gases due to activation of emplacement drift air and host rock is estimated to be low as demonstrated in the following manner. By correcting the calculated activity in Table 5-10 of Radiological Releases Due to Air and Silica Dust Activation in Emplacement Drifts (BSC 2003 [DIRS 164562]) for an infinite irradiation time for stagnant air, activation of emplacement drift air generates $9.0 \times 10^{-11} \mu \mathrm{Ci} / \mathrm{ml}$ of ${ }^{16} \mathrm{~N}$ and $7.4 \times 10^{-9} \mu \mathrm{Ci} / \mathrm{ml}$ of ${ }^{41}$ Ar. The ${ }^{16} \mathrm{~N}$ activity is identical to the value in Table 5-10 of Radiological Releases Due to Air and Silica Dust Activation in Emplacement Drifts (BSC 2003 [DIRS 164562]) at the exhaust shaft inlet. This value is applicable as it represents the saturated activity without radioactive decay. The ${ }^{41} \mathrm{Ar}$ activity includes a correction factor of $1 /\left(1-\mathrm{e}^{-0.3787^{*} 0.252}\right)=\sim 11.0$ (BSC 2003 [DIRS 164562], Section 5.7.1, example) for the saturated activity. The resulting ${ }^{41} \mathrm{Ar}$ activity is estimated as: $6.7 \times 10^{-10} \mu \mathrm{Ci} / \mathrm{ml}$ (BSC 2003 [DIRS 164562], Table 5-10, at the exhaust shaft inlet) $\times 11.0=7.4 \times 10^{-9} \mu \mathrm{Ci} / \mathrm{ml}$. 
Activation of host rock produces $2.1 \times 10^{-7} \mu \mathrm{Ci} / \mathrm{ml}$ of ${ }^{16} \mathrm{~N}$ at the drift wall (BSC 2003 [DIRS 164562], Table 5-11). This activity represents the saturated value without radioactive decay.

In units of $\mathrm{g} / \mathrm{ml}$, the corresponding values are $9.0 \times 10^{-28} \mathrm{~g} / \mathrm{ml}$ of ${ }^{16} \mathrm{~N}$ and $1.7 \times 10^{-22} \mathrm{~g} / \mathrm{ml}$ of ${ }^{41} \mathrm{Ar}$ from neutron activation of air, and $2.1 \times 10^{-24} \mathrm{~g} / \mathrm{ml}$ of ${ }^{16} \mathrm{~N}$ from neutron activation of host rock. These concentration values are at the commencement of waste package emplacement and will be less at the time of closure and further decrease with time. The quantities of radioactive gases produced from activation of emplacement drift air and host rock are insignificant compared to the density of air which is $1.204 \times 10^{-3} \mathrm{~g} / \mathrm{ml}$, as shown in CRC Handbook of Chemistry and Physics (Weast 1985 [DIRS 111561], p. F-10, for $20^{\circ} \mathrm{C}$ and $760 \mathrm{~mm} \mathrm{Hg}$ ) and hence inconsequential to in-drift conditions.

All radionuclides in the nominal scenario for TSPA-LA are transported from the repository to the accessible environment into the aqueous phase (DOE 2002 [DIRS 155970], Section I.7). This is expected to bound any dose effects of gas-phase transport in the geosphere. The only radionuclides that would have a potential for gas transport are ${ }^{14} \mathrm{CO}_{2}$ and ${ }^{222} \mathrm{Rn}$ as discussed in FEP 2.2.11.03.0A of Features, Events, and Processes in UZ Flow and Transport (BSC 2005 [DIRS 174191], Section 6.7.3). An analysis of the potential dose from gas-phase geosphere transport of ${ }^{14} \mathrm{CO}_{2}$ has been done for the individual maximum radiological dose rate. It was found that the dose from aqueous geosphere transport of ${ }^{14} \mathrm{CO}_{2}$ bounds the dose from gas-phase geosphere transport pathways. Aqueous geosphere transport pathway will also bound the dose from ${ }^{222} \mathrm{Rn}$, primarily through aqueous transport of the parent uranium radionuclide and generation of ${ }^{222} \mathrm{Rn}$ as a decay product at the accessible environment (BSC 2005 [DIRS 174191], Section 6.7.3).

Radioactive gaseous elements of potential concern at Yucca Mountain are radioactive fission gases and radon (see FEP 2.1.12.07.0A in Section 6.2.79 of the current report). No significant gas buildup within the EBS will occur. Fuel rods are filled with helium during assembly to improve heat transfer across the pellet/cladding gap. Helium pressure within the rod increases as alpha decay adds helium to the gas present, as discussed under FEP 2.1.12.02.0A in Cladding Degradation - FEPs Screening Arguments (BSC 2004 [DIRS 170019], Section 6.2.23). The fission gas inventory, particularly krypton and xenon, remains essentially constant with time in the repository; further, most of the fission gas that is produced is held in the fuel matrix and is not available to pressurize the cladding as described in Initial Cladding Condition (CRWMS M\&O 2000 [DIRS 151659], Section 6.3). Helium constitutes approximately 98\% of the gas; $\mathrm{Ar}, \mathrm{Kr}$, and $\mathrm{Xe}$ about 1\%; and remaining gases about 1\% (Manaktala 1993 [DIRS 101719], Section 3.3.6).

As described in Initial Cladding Condition (BSC 2004 [DIRS 170019], Section 6.2.23), total anticipated pressures within fuel rods will remain below the pressure necessary for cladding failure. Further, during postclosure times, radioactive gas production will not be sufficient to cause waste-package internal pressures to increase to the extent that a waste-package breach will occur (see FEP 2.1.12.01.0A in Section 6.2.74 of the current report), based on the above arguments. As a result, these gases will be retained within fuel rod cladding and waste containers, since their failure rates are extremely low. If a small percentage of cladding and waste packages fail, the total quantities of radioactive gases released will be small. 
If the waste package and invert were to become largely saturated, gas bubbles in advecting water in the waste package and invert could potentially affect advective and diffusive flow paths. The most plausible situation is one in which bubbles could lodge in pore spaces or fractures, forcing diversion of flow to neighboring flow paths. However, this would occur on a very localized scale, given the very small quantities of gas anticipated, and the overall flow path, which is primarily downward, would be unaffected.

As discussed in Features, Events, and Processes in UZ Flow and Transport (BSC 2005 [DIRS 174191], Section 6.2.35) as part of FEP 2.2.10.10.0A, two-phase buoyant flow may occur as a result of waste-generated heat. Two-phase circulation continues until the heat source is too weak to provide the thermal gradients required to drive it. Therefore, this process would be temporary and would shut down at some point during cool-down.

In summary, gas transport in the EBS will not have a significant effect on performance. Therefore, the magnitude and time of the resulting radiological exposures to the RMEI or radionuclide releases to the accessible environment would not be significantly changed by the exclusion of this FEP.

Repository pressurization is discussed in Section 6.2.74 of the present report under FEP 2.1.12.01.0A.

TSPA Disposition:

N/A

Supporting Documents:

N/A

\subsubsection{Effects of Radioactive Gases in EBS}

\section{FEP Number:}

2.1.12.07.0A

FEP Description: Radioactive gases may exist or be produced in the repository. These gases may subsequently escape from the repository. Typical radioactive gases include ${ }^{14} \mathrm{C}$ (in ${ }^{14} \mathrm{CO}_{2}$ and ${ }^{14} \mathrm{CH}_{4}$ produced during microbial degradation), tritium, fission gases (Ar, $\mathrm{Xe}, \mathrm{Kr}$ ), and radon.

\section{Screening Decision:}

Excluded (Low Consequence)

Screening Argument: Gases occupying the inside of a waste package prior to disposal will include fission-product and neutron-activated stable and radioactive noble gases. Radioactive gases may include ${ }^{14} \mathrm{CO}_{2}$, tritium, fission gases ( $\mathrm{Ar}, \mathrm{Xe}, \mathrm{Kr}$ ) and radon ( $\mathrm{Rn}$ ).

Fuel rods are filled with helium during assembly to improve heat transfer across the pellet/cladding gap. As discussed in Cladding Degradation - FEPs Screening Arguments (BSC 2004 [DIRS 170019], Section 6.2.23) as part of FEP 2.1.12.02.0A, helium pressure within the rod increases as alpha decay adds helium to the gas present. The fission gas inventory, 
particularly krypton and xenon, remains essentially constant with time in the repository; further, as described in Initial Cladding Condition (CRWMS M\&O 2000 [DIRS 151659], Section 6.3), most of the fission gas that is produced is held in the fuel matrix and is not available to pressurize the cladding. Helium constitutes approximately $98 \%$ of the gas; $\mathrm{Ar}, \mathrm{Kr}$, and $\mathrm{Xe}$ about 1\%; and remaining gases about 1\% (Manaktala 1993 [DIRS 101719], Section 3.3.6).

Radioactive gases residing in fuel rods and waste packages prior to postclosure or produced during postclosure will either decay rapidly or quickly become negligible in terms of mass and volume. Argon, krypton, and radon are not significant to calculating dose due to short half-lives compared to the functional life of the waste packages (Dean 1992 [DIRS 100722], Table 4.16). Xenon is also negligible since the half-lives of the isotopes are on the order of a few days, and tritium has a half-life of about 12 years (Dean 1992 [DIRS 100722], Table 4.16). As discussed in Evaluation of Potential Impacts of Microbial Activities on Drift Chemistry (BSC 2004 [DIRS 169991], Section 7.1), generation of carbon dioxide as ${ }^{14} \mathrm{CO}_{2}$ from microbial activity will not be significant. Methane as ${ }^{14} \mathrm{CH}_{4}$ could be produced by microbes under anaerobic conditions (BSC 2004 [DIRS 169991], Section 6.1.3). However, Engineered Barrier System: Physical and Chemical Environment (BSC 2005 [DIRS 175083], Section 6.7.1) presents values of oxygen flux into (or out of) the drift at the crown, side, and bases of the drift as a function of time over the repository regulatory period. The oxygen balance evaluation concludes that oxidizing conditions will persist in the in-drift environment indefinitely. Thus methane production due to this process will be negligible.

As discussed in Cladding Degradation - FEPs Screening Arguments (BSC 2004 [DIRS 170019], Section 6.2.23) and Initial Cladding Condition (CRWMS M\&O 2000 [DIRS 151659], Section 6.3), total anticipated pressures within fuel rods will remain below the pressure necessary for cladding failure. Further, during postclosure times, radioactive gas production will not be sufficient to cause waste-package internal pressures to increase to the extent that a waste-package breach will occur (see FEP 2.1.12.01.0A in Section 6.2.74 of the current report), based on the above arguments. As a result these gases will be retained within fuel rod cladding and waste containers, since their failure rates are extremely low. If a small percentage of cladding and waste packages fail, the total quantities of radioactive gases released will be small.

The isotope ${ }^{14} \mathrm{C}$ is formed from nitrogen in a reactor through neutron capture and proton decay. Neutron flux from decay of waste would be mostly contained within a waste package, i.e., neutrons would not penetrate the waste package skin, so that any neutrons penetrating the skin would have insufficient energy to form ${ }^{14} \mathrm{C}$ from ambient carbon. Radiological Releases Due to Air and Silica Dust Activation in Emplacement Drifts (BSC 2003 [DIRS 164562], Section 6) provides a calculation of potential neutron activation products in the drift air and dust during the preclosure period. Activation product releases in the drift are estimated to be low (BSC 2003 [DIRS 164562], Section 6).

All radionuclides in the nominal scenario for TSPA-LA are transported from the repository to the accessible environment into the aqueous phase (DOE 2002 [DIRS 155970], Section I.7). This is expected to bound any dose effects of gas-phase transport in the geosphere. The only radionuclides that would have a potential for gas transport are ${ }^{14} \mathrm{CO}_{2}$ and ${ }^{222} \mathrm{Rn}$ as discussed in FEP 2.2.11.03.0A of Features, Events, and Processes in UZ Flow and Transport (BSC 2005 
[DIRS 174191], Section 6.7.3). An analysis of the potential dose from gas-phase geosphere transport of ${ }^{14} \mathrm{CO}_{2}$ has been done for the individual maximum radiological dose rate. It was found that the dose from aqueous geosphere transport of ${ }^{14} \mathrm{CO}_{2}$ bounds the dose from gas-phase geosphere transport pathways. Aqueous geosphere transport pathway will also bound the dose from ${ }^{222} \mathrm{Rn}$, primarily through aqueous transport of the parent uranium radionuclide and generation of ${ }^{222} \mathrm{Rn}$ as a decay product at the accessible environment (BSC 2005 [DIRS 174191], Section 6.7.3).

Therefore, omission of radioactive gas effects will not significantly change the calculated radiological exposures or radionuclide releases.

In summary, radioactive gas effects in the EBS will not be significant, and the magnitude and time of the resulting radiological exposures to the RMEI or radionuclide releases to the accessible environment would not be significantly changed by the exclusion of this FEP.

The effect of gas on waste package degradation is discussed under FEP 2.1.12.07.0A in Waste-Form Features, Events, and Processes (BSC 2004 [DIRS 170020], Section 6.2.36).

TSPA Disposition:

N/A

Supporting Documents:

$\mathrm{N} / \mathrm{A}$

\subsubsection{Gas Explosions in EBS}

\section{FEP Number:}

2.1.12.08.0A

FEP Description: Explosive gas mixtures could collect in the sealed repository. An explosion in the repository could have radiological consequences if the structure of the repository were damaged or near-field processes enhanced or inhibited.

\section{Screening Decision:}

Excluded (Low Probability)

Screening Argument: As discussed in Sections 6.2.76 and 6.2.77 (FEPs 2.1.12.03.0A and 2.1.12.04.0A, respectively), certain sources for gas generation may result in the production of flammable gases. Flammable gases that may be present include hydrogen $\left(\mathrm{H}_{2}\right)$, methane $\left(\mathrm{CH}_{4}\right)$, and acetylene $\left(\mathrm{C}_{2} \mathrm{H}_{2}\right)$. Hydrogen is discussed in Section 6.2.76 of the current report under FEP 2.1.12.03.0A, while methane is discussed in Section 6.2.77 under FEP 2.1.12.04.0A. Acetylene is discussed under FEP 2.1.02.29.0A in Waste Form Features, Events, and Processes (BSC 2004 [DIRS 170020], Section 6.2.17).

Hydrogen would be produced from the radiolysis of water $\left(\mathrm{H}_{2} \mathrm{O}\right)$ (Glass et al. 1986 [DIRS 105021]) or oxidation of metals under anaerobic conditions. Methane could be produced from the microbial action on organics or the metal containers. Acetylene could be produced if moisture comes in contact with the carbide component of the uranium carbide DOE fuel. If a 
flammable mixture of gases were to exist, an explosion could not occur without an ignition source. It is conceivable that rockfall or seismic event could produce a spark to ignite a flammable gas mixture.

As discussed in Evaluation of Potential Impacts of Microbial Activities on Drift Chemistry (BSC 2004 [DIRS 169991], Section 6.1.3), the quantities of methane and hydrogen that could reasonably be generated external to a waste package are small because both are the by-products of anaerobic conditions. Methane could be produced by microbes, and hydrogen is the by-product of anaerobic oxidation of metals. Engineered Barrier System: Physical and Chemical Environment (BSC 2005 [DIRS 175083], Section 6.7.1) presents values of oxygen flux into (or out of) the drift at the crown, side, and bases of the drift as a function of time over the repository regulatory period. The oxygen balance evaluation concludes that oxidizing conditions will persist in the in-drift environment indefinitely. Thus, hydrogen or methane production due to these processes will be negligible.

Because the repository is located in unsaturated rock units with pervasive fracture networks, as discussed in Drift Degradation Analysis (BSC 2004 [DIRS 166107], Section 6.1.4), flammable gases will be dispersed into the surrounding rock mass. The lower explosion limit for hydrogen in air is $4.1 \%$ at $25^{\circ} \mathrm{C}$ and one atmosphere total pressure (Dean 1992 [DIRS 100722], Table 5.22). Flammable gases could therefore not accumulate in sufficient quantities in emplacement drifts to support a combustible mixture. Corroboration to gas dispersion is given in Section 6.2.74 of the current report (FEP 2.1.12.01.0A).

Radiolysis of water internal to the waste package could only occur after the waste package is breached and water enters the breach. A waste package breach is unlikely due to the durability of the waste packages and resistance to general and localized corrosion, as shown in IED Interlocking Drip Shield and Emplacement Pallet [Sheet 1 of 1] (BSC 2005 [DIRS 173303]) and General Corrosion and Localized Corrosion of the Drip Shield (BSC 2004 [DIRS 169845], Section 6.3). Water entering the package in appreciable quantities is precluded by the presence and configuration of the drip shield as described in Subsurface Facility Description Document (BSC 2005 [DIRS 174514], Figure 4-10), and by the location of the repository in the UZ. The general configuration of the drip shield positioned over the waste packages will endure through a seismic event, as discussed in Seismic Consequence Abstraction (BSC 2005 [DIRS 173247], Section 6.5.5) and in Section 6.2.8 of the present document under FEP 1.2.03.02.0A. Large displacements on known faults in the repository block may shear waste packages and drip shields if the EBS components become pinned by the fault response. Such a response could occur from extremely low frequency, high amplitude fault displacements, corresponding to an annual exceedance frequency of less than or equal to $10^{-7}$ per year (BSC 2005 [DIRS 173247], Section 6.3.1). If this were to occur, and later seepage entered a waste package, conditions would exist for radiolysis of water that could generate hydrogen.

If water entered waste packages, the package would subsequently need to be virtually sealed in order to develop hydrogen of sufficient concentration to become a flammable mixture. If a waste package were sheared, there is no known mechanism for it to later seal. Sealing could conceivably occur if one of the following conditions were to exist: 1) if the breaches were tight cracks sufficiently large to let water in and then later plug, as discussed in FEP 2.1.03.10.0A in Section 6.2.63 of the current document; 2) if openings in waste packages were small enough that 
ventilation is poor; or 3) if packages were anticipated to be submerged in water, thereby restricting ventilation of gas. None of these combinations of conditions are anticipated to occur at Yucca Mountain.

Additional confidence in the decision to exclude gas explosions within waste packages from the TSPA comes from the observation that, even if it were possible for such gas explosions to occur, the incremental impact on the system-level performance of a small number of such events would be negligible. This conclusion results from the reasonable interpretation that the primary effect of a gas explosion would be to damage the waste form (i.e., cause cladding failure) and the breach welds on the waste package. TSPA does not assume that openings in packages can seal after forming, as described in General Corrosion and Localized Corrosion of Waste Package Outer Barrier (BSC 2004 [DIRS 169984]). Failure of a weld in a package that is already breached would have little or no impact on calculated radionuclide releases. Damage to the waste form could potentially impact the rate at which radionuclides are released into water. However, in the seismic scenario class discussed in Seismic Consequence Abstraction (BSC 2005 [DIRS 173247]), in which ground motion has the potential to create openings in waste packages (BSC 2005 [DIRS 173247], Sections 6.5.1 to 6.5.3) that could allow water to reach the waste (if it somehow were to penetrate the drip shield), cladding failure is also predicted to occur (BSC 2005 [DIRS 173247], Section 6.5.6.3 and Table 6.5-16). Thus, the rate of radionuclide release from the waste form is already high in the scenario in which package breaches are most likely to occur.

Waste-Form Features, Events, and Processes (BSC 2004 [DIRS 170020], Section 6.2.17, FEP 2.1.02.29.0A) excludes production of acetylene because the volume of DSNF is a small percent of the total waste inventory and is dispersed among the CSNF. Acetylene from breached DSNF packages will be diluted, and its concentration will be below threshold for combustion (BSC 2004 [DIRS 170020], Section 6.2.17).

The above discussion demonstrates that accumulation of a flammable mixture of gases is highly unlikely, either inside or outside of waste packages. The possibility of explosion is further reduced because an ignition event is unlikely. A rockfall, major seismic event, or some other currently unidentified event would need to create an ignition source at the same time and place where explosive gases had accumulated.

The conditions necessary to create a mixture of explosive gases and, at the same time and place, to have an event to initiate ignition of the mixture is sufficiently unlikely that it is screened out on the basis of low probability.

TSPA Disposition:

N/A

\section{Supporting Documents:}

$\mathrm{N} / \mathrm{A}$ 


\subsubsection{Radiolysis}

FEP Number:

2.1.13.01.0A

FEP Description: Alpha, beta, gamma, and neutron irradiation of water can cause disassociation of molecules, leading to gas production and changes in chemical conditions (potential, $\mathrm{pH}$, and concentration of reactive radicals).

\section{Screening Decision:}

Excluded (Low Consequence)

Screening Argument: This FEP addresses radiolysis of aqueous solutions and moist air that may occur in the EBS. Radiolysis refers to molecular disintegration resulting from radiation, which may initiate other chemical reactions or alter local chemistry. In pure water systems, radiolysis can produce a large number of radicals and molecules containing hydrogen and oxygen. For $\mathrm{UO}_{2}$ samples in solutions containing $\mathrm{H}_{2} \mathrm{O}_{2}$, radicals produced by radiolysis are more effective than $\mathrm{H}_{2} \mathrm{O}_{2}$ in oxidation of $\mathrm{UO}_{2}$ (Christensen and Sunder 2000 [DIRS 162387], p. 104). Radiolysis of air results in the fixation of atmospheric $\mathrm{N}_{2}$ in gaseous nitrogen oxides. These gaseous products can dissolve in any liquid water present, forming aqueous nitric acid. Two species, nitric acid $\left(\mathrm{HNO}_{3}\right)$ and hydrogen peroxide $\left(\mathrm{H}_{2} \mathrm{O}_{2}\right)$, may be of concern due to their potentially corrosive effects. For a given chemical system and set of environmental conditions, the qualities of nitric acid and hydrogen peroxide produced are directly proportional to the amount of energy deposited in the material and, thus, are directly proportional to the dose rate.

The gamma radiation levels for a bounding-case waste package containing 21-PWR spent fuel assemblies are described in Dose Rate Calculation for 21-PWR Waste Package (BSC 20004 [DIRS 172227], Table 6.4-3) and Screening of Features, Events, and Processes in Drip Shield and Waste Package Degradation (BSC 2005 [DIRS 174995], Section 6.2.31). The maximum radiation levels were determined at initial emplacement. The levels computed were $1,170 \mathrm{rad} / \mathrm{hr}$ at the waste package surface and $1,650 \mathrm{rad} / \mathrm{hr}$ at the outer lid of the waste package. In 50 years these values drop to $100 \mathrm{rad} / \mathrm{hr}$ for the waste package surface and $80 \mathrm{rad} / \mathrm{hr}$ for the outer lid. During the initial 50 years (minimum preclosure period) of the repository operations, drift ventilation will be in effect. During the ventilation period, liquid water will not be present in the drifts, the humidity will be low, and the gas phase will be continuously exchanged with fresh air. As a result, radiolysis effects will be insignificant. As summarized in Screening Analysis of Criticality Features, Events, and Processes for License Application (BSC 2005 [DIRS 173869], Table 7.2-1), no criticality events are expected to occur in the repository. Thus, the dose rates calculated at the surface of a spent fuel package containing a bounding inventory of fuel are expected to bound the dose rates within the drifts.

During the postclosure period, potentially significant radiolysis effects on the in-drift chemical environment are limited to those produced by gamma irradiation. As discussed in Screening of Features, Events, and Processes in Drip Shield and Waste Package Degradation (BSC 2005 [DIRS 174995], Section 6.2.32), Waste-Form Features, Events, and Processes (BSC 2004 [DIRS 170020], Section 6.2.37), and in Technical Report of Calculations Supporting Evaluation of Radiation Effects (BSC 2003 [DIRS 164012]), the effects of alpha and beta irradiation are 
minimal, as these particles are stopped by the waste package barriers. Calculations presented in Technical Report of Calculations Supporting Evaluation of Radiation Effects (BSC 2003 [DIRS 164012]) have shown that the neutron irradiation is negligible. The gamma radiation levels are shown to be greater than the neutron levels by more than an order of magnitude for PWR SNF packages (BSC 2004 [DIRS 172227], Table 6.3-2). Therefore, the major contributor to the dose rate is gamma radiation. By 100 years after emplacement, the maximum calculated radiation levels have declined to about $35 \mathrm{rad} / \mathrm{hr}$ for the waste package outer barrier surface, and $20 \mathrm{rad} / \mathrm{hr}$ for the outer lid region, as shown in Dose Rate Calculation for 21-PWR Waste Package (BSC 2004 [DIRS 172227], Table 6.4-3) and IED Waste Package Radiation Characteristics [Sheet 1 of 1] (BSC 2005 [DIRS 173426]). The bounding radiation levels for the highest burnup spent fuel are well below the levels at which the effects of radiolysis have been observed. Thus, it is expected that the quantities of radiolytically generated products will be about 2 moles in 395 years (BSC 2004 [DIRS 164012], Table 4-7) and the constituents will not affect other EBS materials in the repository drift (BSC 2005 [DIRS 174995], Section 6.2.31).

In the non-drip scenario, a thin film of moisture may form on the waste package. Radiolysis involving this water film is discussed in Screening of Features, Events, and Processes in Drip Shield and Waste Package Degradation (BSC 2005 [DIRS 174995], Section 6.2.31). Radiolysis and its effects on waste form degradation chemistry are discussed in Waste-Form Features, Events, and Processes (BSC 2004 [DIRS 170020], Section 6.2.37). It is shown that model predictions with significant increases of nitric acid and hydrogen peroxide to the in-package chemistry do not result in changes or chemical potential or $\mathrm{pH}$ sufficiently to alter the outcome of model results. Dust deliquescence on the waste package surface is discussed in FEP 2.1.09.28.0A (Section 6.2.61 of the current report). Brines on the waste package surface generated by dust deliquescence will degas acid phases - $\mathrm{HCl}$ and $\mathrm{HNO}_{3}$ - which can lead to less deliquescent salts and dryout. All predicted deliquescent brine compositions are unstable in the drift environment and will degas acid phases.

Radiolysis will not significantly affect the chemistry of seepage water that may come into contact with the EBS components. In the drip scenario (and in the extreme case that the drip shield fails), seepage water enters the drift and contacts EBS components. This water contains dissolved species, including chloride and bicarbonate ions. As discussed in In-Package Chemistry Abstraction (BSC 2004 [DIRS 174583], Appendix B), nitric acid and hydrogen peroxide may form. If these species were to be produced, they would tend to promote corrosion. Based on this study, it may be stated that radiolysis will not affect the in-package chemistry in a manner that would impact TSPA-LA (BSC 2004 [DIRS 174583], Appendix B, Section B.6).

In summary, the effects of radiolysis in the EBS external to the package can be excluded from consideration in the TSPA-LA based on low consequence. While radiolysis may result in some additional gas generation, the impacts of gas generation on repository pressurization have been excluded (see FEP 2.1.12.01.0A in Section 6.2.74 of the present report). Thus, radiolysis can be excluded from this perspective as well.

Therefore, the exclusion of radiolysis effects in the EBS from the TSPA-LA will not have a significant effect on radiological exposures to the RMEI or radiological releases to the accessible environment. 


\section{TSPA Disposition:}

N/A

\section{Supporting Documents: \\ $\mathrm{N} / \mathrm{A}$}

\subsubsection{Radiation Damage in EBS}

\section{FEP Number:}

2.1.13.02.0A

FEP Description: Radiolysis due to the alpha, beta, gamma-ray, and neutron irradiation of water could result in enhancement of the radionuclide migration from the surface of a degraded waste form into groundwater. When radionuclides decay, the emitted high-energy particle could result in the production of radicals in the water or air surrounding the spent nuclear fuel. If these radicals migrate (diffuse) to the surface of the fuel, they may then enhance the degradation/corrosion rate of the fuel (UO2). This effect would increase the dissolution rate for radionuclides from the fuel material (fuel matrix) into the groundwater. Strong radiation fields could lead to radiation damage to the waste forms (CSNF, DSNF, DHLW), waste packages, drip shield, seals, and surrounding rock.

\section{Screening Decision:}

Excluded (Low Consequence)

Screening Argument: The potential for radiation to damage waste forms is excluded based on low consequence in Waste-Form Features, Events, and Processes (BSC 2004 [DIRS 170020], Section 6.2.38, FEP 2.1.13.02.0A). Hydride cracking of the waste package and drip shields are excluded by FEPs 2.1.03.04.0A and 2.1.03.04.0B in Screening of Features, Events, and Processes in Drip Shield and Waste Package Degradation (BSC 2005 [DIRS 174995], Sections 6.2.8 and 6.2.9).

An evaluation of the potential for repository radiation fluxes to damage the waste package, pallet and drip shield is discussed and screened out under FEP 2.1.13.02.0A in Screening of Features, Events, and Processes in Drip Shield and Waste Package Degradation (BSC 2005 [DIRS 174995], Section 6.2.32). This evaluation argues that while it is likely that some radiation damage will occur to the waste package and pallet, the estimated neutron fluence is below the neutron fluence threshold by a considerable margin. Therefore, the mechanical properties of the waste package and pallet will not be altered by radiation damage. Due to the more remote position of the drip shield relative to the radiation source, the drip shield will be subject to less damage by these radiation fluxes. These evaluations are based on data given in Nuclear Engineering Handbook (Etherington 1958 [DIRS 164789], p. 10-107), which identifies radiation levels below which there is no change to mechanical properties of stainless steel, nickel, and molybdenum.

Section 6.2.81 (FEP 2.1.13.01.0A) of the current report discusses the potential for alteration of seepage water chemistry in the presence of radiation fields near the waste packages and concludes that competing chemical reactions will maintain the $\mathrm{pH}$ at moderate values and 
prohibit excursions to low $\mathrm{pH}$. Thus the chemistry of groundwater is not expected to be materially influenced by these radiation fields.

Radiation is not expected to damage seals within the repository because the seals are remote with respect to the radiation sources. As described in Subsurface Facility Description Document (BSC 2005 [DIRS 174514], Section 4.1.1.3.6.4), closure of the repository subsurface facilities requires closing and sealing all openings from the surface to the underground facilities. These openings consist of the north ramp, south ramp, north construction ramps and portals, ventilation shafts/raises, and exploratory boreholes within the repository footprint (the waste emplacement area projected vertically to the surface), and in a buffer zone around the footprint boundary. The locations of each of the ramps, portals, and ventilation shafts and raises are shown not to be in emplacement drifts in Subsurface Facilities Overall Layout (BSC 2003 [DIRS 165315]). Additionally, sealing of ventilation shafts/raises and boreholes provides properties consistent with the host rock (BSC 2005 [DIRS 174514], Section 2.2), which is discussed below.

As discussed in Dose Rate Calculation for 21-PWR Waste Package (BSC 2004 [DIRS 172227], Section 6.5), radiation effects on ground control materials were determined to be insignificant, as the cumulative neutron fluence over 300 years is well below the threshold of mechanical property changes. Gamma radiation will have no effect on the 316 SS ground support. These findings are corroborated for the host rock by data presented in Effect of Radiation on the Mechanical Properties of Topopah Spring Tuff (Blair et al. 1996 [DIRS 129637]) where tuff specimens were irradiated with large doses of gamma radiation (9.5 Mgy maximum, from Blair et al. 1996 [DIRS 129637], Table 3) and uniaxially tested to measure maximum strength and Young's modulus. Table 5 of the report demonstrates that there is little difference between results from the two sets of cores tested, with an average decrease of less than $10 \%$ in each of the material properties (peak strength and Young's modulus).

Therefore, omission of radiation damage in the EBS from the TSPA-LA will not have a significant effect on the magnitude and time of the resulting radiological exposures to the RMEI or radionuclide releases to the accessible environment.

TSPA Disposition:

N/A

Supporting Documents:

N/A

\subsubsection{Radiological Mutation of Microbes}

\section{FEP Number:}

2.1.13.03.0A

FEP Description: Radiation fields could cause mutation of microorganisms, leading to unexpected chemical reactions and impacts.

\section{Screening Decision:}

Excluded (Low Consequence) 
Screening Argument: Evaluation of Potential Impacts of Microbial Activities on Drift Chemistry (BSC 2004 [DIRS 169991], Section 6.4) provides a thorough discussion of several repository-specific environmental constraints on microbial activity. Factors considered include: temperature, pressure, oxic and anoxic conditions, relative humidity, water availability, $\mathrm{pH}$, salinity, nutrient availability, biofilm formation, and radiation effect. The conclusions from that analysis are summarized in Section 6.2.65 of the present report under FEP 2.1.10.01.0A. The evaluation shows that environmental factors will severely limit microbial activities in the repository and that, therefore, the potential impact of microbial activity on drift chemistry does not warrant a direct feed to the TSPA-LA (BSC 2004 [DIRS 169991], Section 7.1). The limiting factors for microbial growth apply to all microbial life forms, not only those found in the Yucca Mountain Repository. It can therefore be concluded that any mutations within the microbial community, regardless of the effects on the microbes, would be subject to the same severe limits on growth. Evaluation of Potential Impacts of Microbial Activities on Drift Chemistry (BSC 2004 [DIRS169991], Section 7.1) concludes that the effects from microbes on in-drift chemistry may be neglected in the TSPA-LA.

Based on the foregoing discussion of limiting environmental factors, the potential effects of microbial mutations in the EBS are excluded from TSPA-LA on the basis of low consequence. The omission of FEP 2.1.13.03.0A will not have a significant effect on the magnitude and time of the resulting radiological exposures to the RMEI or radionuclide releases to the accessible environment.

TSPA Disposition:

N/A

Supporting Documents:

N/A

\subsubsection{Thermally-Induced Stress Changes in the Near-Field}

\section{FEP Number:}

2.2.01.02.0A

FEP Description: Changes in host rock properties may result from thermal effects or other factors related to emplacement of the waste. Properties that may be affected include rock strength, fracture spacing and block size, and hydrologic properties such as permeability and sorption.

\section{Screening Decision:}

Excluded (Low Consequence)

Screening Argument: This FEP also appears in Features, Events, and Processes in UZ Flow and Transport (BSC 2005 [DIRS 174191], Section 6.9.3), which discusses effects on permeability (coupled thermal-hydrologic-mechanical effects) and sorption. Thermal effects are evaluated as part of Drift Degradation Analysis (BSC 2004 [DIRS 166107], Section 6.2) as follows: the analysis of rockfall provides rockfall models that explicitly include the potential impact of thermally induced stress changes in the rock mass. The effects of thermally induced 
stress changes are documented in that report for nonlithophysal rock and for lithophysal rock (BSC 2004 [DIRS 166107], Sections 6.3.1.3 and 6.4.2.3, respectively).

While these effects are part of Drift Degradation Analysis (BSC 2004 [DIRS 166107], Section 8.1) and therefore incorporated into the rockfall calculations, rockfall in the nominal scenario has been excluded (see FEP 2.1.07.01.0A in Section 6.2.28 of the present report). Seismic-induced rockfall is also excluded (see FEP 1.2.03.02.0B in Section 6.2.9 of the present report).

The effects of thermal induced stress changes around the emplacement drifts on drift seepage were evaluated in Abstraction of Drift Seepage (BSC 2004 [DIRS 169131] Section 6.4.4). The Drift-Scale Thermal-Hydrological-Mechanical (THM) Model was applied to assess the magnitude and distribution of stress-induced changes in hydrological properties due to repository heating (BSC 2004 [DIRS 169131], Section 6.4.4). The report concludes that when comparing the fully coupled THM simulations with TH simulations where the stress-induced property changes were neglected that that the flow field differences are small to moderate. The reduction in vertical permeability, combined with the basically unchanged horizontal permeability, appeared to give rise to less water reaching the drift crown (BSC 2004 [DIRS 169131], Figure 6.4-32). It was concluded in Seepage Model for PA Including Drift Collapse (BSC 2004 [DIRS 167652], Section 6.7) that these anisotropic THM property changes would increase the likelihood of flow being diverted around the drift and thus decrease the potential for seepage. Based upon these analyses, it is concluded that thermally induced stresses have a minimal impact on the hydrologic performance of the emplacement drift.

Analysis of rockfall has been performed to explicitly evaluate the impact of thermally induced stress changes, and other factors including uncertainty in rock characteristics. For nonlithophysal tuff, three-dimensional discontinuum thermal-mechanical analyses were conducted using ranges of thermal properties and ventilation heat removal efficiency values. Minimal rockfall is predicted for thermal loading only. When thermal stresses are considered in combination with the stresses resulting from postclosure seismic ground motion, the thermal loading significantly reduces the amount of rockfall (BSC 2004 [DIRS 166107], Section 6.3.1.4). Similar analyses were performed to evaluate time-dependent rock joint degradation, with the result that joint strength degradation has a minor impact on drift stability in nonlithophysal rock.

For lithophysal tuff, two-dimensional discontinuum analyses were performed, also using ranges of thermal properties and ventilation heat removal efficiency values. The analyses were repeated for five categories of rock mass properties representing the variability in lithophysal rock quality expected at the repository level. No significant rockfall is predicted due to heating for any of the five rock property categories, irrespective of the ventilation efficiency or thermal properties. Little or no rockfall is calculated to occur as a result of preclosure ground motion. Postclosure ground motion causes drift collapse in the lithophysal tuff (BSC 2004 [DIRS 166107], Section 8.1).

In summary, the omission of thermally induced stress changes in the near-field from the TSPA-LA as defined in FEP 2.2.01.02.0A will not have a significant effect on the magnitude and time of the resulting radiological exposures to the RMEI or radionuclide releases to the accessible environment. 
TSPA Disposition:

N/A

Supporting Documents:

N/A

\subsubsection{Chemical Changes in the Near-Field from Backfill}

\section{FEP Number:}

2.2.01.02.0B

FEP Description: Changes in host rock properties may result from chemical effects of backfill. Properties that may be affected include permeability and sorption.

Screening Decision:

Excluded (Low Probability)

Screening Argument: As discussed in Postclosure Modeling and Analyses Design Parameters (BSC 2004 [DIRS 169885], Table 4) and in Subsurface Facility Description Document (BSC 2005 [DIRS 174514], Figure 4-10), there is no backfill used in the design baseline in the emplacement drifts at Yucca Mountain. Materials planned to be installed in the repository are summarized in IED Subsurface Facilities Committed Materials [Sheet 1 of 1] (BSC 2005 [DIRS 173871]). Thus, it is not credible that this FEP concerning backfill will occur.

\section{TSPA Disposition:}

N/A

\section{Supporting Documents:}

N/A

\subsubsection{Episodic or Pulse Release from Repository}

\section{FEP Number:}

2.2.07.06.0A

FEP Description: Episodic or pulse release of radionuclides from the repository and radionuclide transport in the UZ may occur both because of episodic flow into the repository, and because of pulse releases from failed waste packages.

\section{Screening Decision:}

Excluded (Low Consequence)

Screening Argument: FEP 2.2.07.06.0A, Episodic or Pulse Release from Repository, is shared with Features, Events, and Processes in UZ Flow and Transport (BSC 2005 [DIRS 174191], Section 6.4.6). The model developed in EBS Radionuclide Transport Abstraction (BSC 2005 [DIRS 173433], Section 6.1) is used to quantify the time-dependent radionuclide releases from a failed waste package and their subsequent transport through the EBS to the emplacement drift wall/UZ interface. The basic inputs to the RTA model consist of the drift seepage influx, the 
environmental conditions in the drift (temperature, relative humidity, water chemistry), and the degradation state of the EBS components. Outputs consist of the rates of radionuclide releases to the UZ as a result of advective and diffusive transport, accounting for the impact of colloids, radionuclide solubility, retardation, and the degree of liquid saturation of the waste form and invert materials. The RTA model is implemented directly into the TSPA-LA GoldSim model to compute the radionuclide release rates from the EBS (BSC 2005 [DIRS 173433], Section 6.1).

The source of potential episodic or pulse inflow to the EBS is seepage and condensation flux that drips from the crown (roof) of the drift. This inflow can flow through the EBS along eight pathways: (1) seepage flux, (2) flux through the drip shield, (3) diversion around the drip shield, (4) flux through the waste package, (5) diversion around the waste package, and (6) flux from the waste package into the invert (BSC 2005 [DIRS 173433], Section 6.3.1.1). Flux through the invert propagates to the unsaturated host rock below the emplacement drift openings. These pathways are time dependent, because drip shield penetrations, and waste package penetrations will vary with time and local conditions in the repository.

Transport from the EBS considered a "bathtub" model, which simulates episodic releases of radionuclides (BSC 2005 [DIRS 173433], Section 6.6.1). As discussed in EBS Radionuclide Transport Abstraction (BSC 2005 [DIRS 173433], Section 6.6.1), this release mode is screened out because sorption and diffusion processes will damp out this episodic process, and due to the large uncertainty in waste package failure modes.

The effect of small-scale variation in permeability on flow channeling near the repository horizon is addressed by the UZ TH seepage model in Abstraction of Drift Seepage (BSC 2004 [DIRS 169131], Section 6.4.3.1; see also FEP 2.2.07.05.0A in BSC 2005 [DIRS 174191], Section 6.4.5). Although precipitation is episodic, the drift-scale abstraction report provides the technical basis for exclusion of the FEP based on findings that UZ flow is effectively steady at the repository and along radionuclide transport pathways (BSC 2004 [DIRS 169131], Section 6.6.5.1). This basis is developed in UZ Flow Models and Submodels (BSC 2004 [DIRS 169861], Section 6.1.2 and G.4), which shows that the PTn unit is expected to dampen and homogenize downward-moving transient pulses arising from episodic surface infiltration events. This conclusion is based on a study by $\mathrm{Wu}$ et al. (2000 [DIRS 154918], Section 4.1 and Figure 4.1-11). Because the flow in the UZ at the repository horizon is steady, it follows that the seepage flux that enters the crown of the drift is relatively steady (BSC 2004 [DIRS 169131], Section 6.6.5.1).

EBS Radionuclide Transport Abstraction (BSC 2005 [DIRS 173433]) is responsive to changes in seepage flux and flow pathways that may occur during simulation. These changes include waste package breach, drip shield breach, waste form degradation, and corrosion of the waste package internals. The bathtub effect, wherein no releases occur until the failed waste package is filled with water, which could result in pulsed releases, is analyzed in EBS Radionuclide Transport Abstraction (BSC 2005 [DIRS 173433], Section 6.6.1) and found to be insignificant in its effect on overall release rates.

Therefore, omission of episodic/pulse releases from the EBS from the TSPA-LA, as discussed in this FEP, will not have a significant effect on the magnitude and time of the resulting radiological exposures to the RMEI or radionuclide releases to the accessible environment. 


\section{TSPA Disposition:}

N/A

\section{Supporting Documents:}

N/A

\subsubsection{Long-Term Release of Radionuclides from the Repository}

\section{FEP Number:}

2.2.07.06.0B

FEP Description: The release of radionuclides from the repository may occur over a long period of time, as a result of the timing and magnitude of the waste packages and drip shield failures, waste form degradation, and radionuclide transport through the invert.

\section{Screening Decision:}

Included

\section{Screening Argument:}

$\mathrm{N} / \mathrm{A}$

TSPA Disposition: FEP 2.2.07.06.0B, Long-Term Release of Radionuclides from the Repository, is shared with Features, Events, and Processes in UZ Flow and Transport (BSC 2005 [DIRS 174191], Section 6.2.16). The model developed in EBS Radionuclide Transport Abstraction (BSC 2005 [DIRS 173433], Section 6.1) is used to quantify the time-dependent radionuclide releases from a failed waste package and their subsequent transport through the EBS to the emplacement drift wall/UZ interface. The basic inputs to the RTA model consist of the drift seepage influx, the environmental conditions in the drift (temperature, relative humidity, water chemistry), and the degradation state of the EBS components. Outputs consist of the rates of radionuclide releases to the UZ as a result of advective and diffusive transport, accounting for the impact of colloids, radionuclide solubility, retardation, and the degree of liquid saturation of the waste form and invert materials. The RTA model is implemented directly into the TSPA-LA GoldSim model to compute the radionuclide release rates from the EBS.

This FEP is included in the RTA model, which imposes no restrictions or conditions on the duration of radionuclide transport.

\section{Supporting Documents:}

BSC 2005 [DIRS 173433]

\subsubsection{Drift Shadow Forms below Repository}

\section{FEP Number:}

$$
\text { 2.2.07.21.0A }
$$

FEP Description: Flow in unsaturated rock tends to be diverted by openings such as waste emplacement drifts due to the effects of capillary forces. Flow diversion around the drift openings could lead to the development of a zone of lower flow rates and low saturation beneath 
the drift, known as the drift shadow. Radionuclide transport rates through the unsaturated rock may be dependent on whether or not radionuclide releases occur from drifts that are underlain by a drift shadow.

Screening Decision: Excluded (Low Consequence)

Screening Argument: The drift shadow effect is a result of flow diversion around drifts (see FEP 2.2.07.20.0A in BSC 2005 [DIRS 174191], Section 6.2.25). Drift-Scale Radionuclide Transport (BSC 2004 [DIRS 170040] Section 6.3.1) describes the conceptual model and numerical implementation of the drift-shadow model. This model accounts for the effects of capillary, gravity, and viscous forces for unsaturated flow. A dual-permeability conceptual model is used to represent flow and transport in fractured rock. The drift shadow model shows that a dryout zone forms within the invert, and welded tuff below the invert with two drip lobes (zones of increased magnitude of vertical water flux) that form through the system of vertical fractures on the sides of the emplacement drifts (BSC 2004 [DIRS 170040], Figure 6-2d).

As discussed in EBS Radionuclide Transport Abstraction (BSC 2005 [DIRS 173433]), this FEP is not included in TSPA-LA through the EBS RTA model. Radionuclide transport is included through the fraction of releases from a waste emplacement drift without seepage to the fractures of the underlying rock mass (BSC 2005 [DIRS 173433], Section 6.5.3.6). This boundary condition (initiation of geosphere transport in the rock matrix or fractures) is found to control, in large part, the general behavior of radionuclide transport through the volume of rock under the drift.

The difference between radionuclide transport for releases in the drift shadow and radionuclide transport for releases into the rock matrix of the unperturbed flow field have been investigated. These results indicate that the drift-shadow effect is approximately equivalent to initiation of transport in the matrix in an unperturbed flow field. Therefore, the dynamics of the drift shadow flow field have only a second-order effect on the breakthrough curves (BSC 2004 [DIRS 170040], Section 6.3.3.3).

The initiation of transport in fractures in an unperturbed flow field will result in greater transport rates as compared to transport initiated in a drift shadow. However, the release of radionuclides in rock fractures comprises only a small fraction of the overall radionuclide releases from drifts without seepage (BSC 2005 [DIRS 173433], Figure 7.3-1) and an even smaller fraction of the total radionuclide releases from the repository. Based on these results, the potential effects of the drift shadow on radionuclide transport are not included in TSPA-LA. In particular, the reduction in flow over a region beneath the waste emplacement drift of the approximate size of the drift is not further considered.

In summary, omission of the effects of a drift shadow from TSPA-LA will not have a significant effect on the magnitude and time of the resulting radiological exposures to the RMEI or radionuclide releases to the accessible environment.

\section{TSPA Disposition:}

N/A 


\section{Supporting Documents:}

N/A

\subsubsection{Re-Dissolution of Precipitates Directs More Corrosive Fluids to Waste Packages}

\section{FEP Number:}

2.2.08.04.0A

FEP Description: Re-dissolution of precipitates that have plugged pores as a result of evaporation of groundwater in the dry-out zone, may produce a pulse of fluid reaching the waste packages when gravity-driven flow resumes, which is more corrosive than the original fluid in the rock.

\section{Screening Decision:}

Included

\section{Screening Argument:}

N/A

TSPA Disposition: FEP 2.2.08.04.0A, Re-dissolution of Precipitates Directs More Corrosive Fluids to Waste Packages, is shared with Features, Events, and Processes in UZ Flow and Transport (BSC 2005 [DIRS 174191], Section 6.2.27). The process of re-dissolution of mineral precipitates is explicitly included in Drift-Scale THC Seepage Model (BSC 2005 [DIRS 172862], Section 6.5.5.3) as part of the UZ analysis. This effect is included as part of the boundary conditions to the EBS analysis, as the thermal-hydrological-chemical seepage model generates the chemical compositions of potential seepage waters that are model input to Engineered Barrier System: Physical and Chemical Environment (BSC 2005 [DIRS 175083], Section 6.6). The thermal-hydrological-chemical model predicts time-dependent seepage water compositions and gas-phase compositions in the host rock (near field environment) adjacent to the drift wall. A discussion of the model used to derive these compositions is presented in Drift-Scale THC Seepage Model (BSC 2005 [DIRS 172862], Sections 6.2 and 6.4). The THC seepage model is based on a specific design basis thermal load and thermal decay rate, which are a function of repository loading and ventilation efficiency (BSC 2005 [DIRS 172862], Section 4.1.7).

Five different waters were selected to represent the spread of measured pore water data that serve as possible starting water compositions for the drift scale THC seepage model. The rationale for the selection of these five waters is discussed in Section 6.2.2.1 of Drift-Scale THC Seepage Model (BSC 2005 [DIRS 172862]). A time-history of potential seepage water compositions is calculated with the thermal-hydrological-chemical model for each of the five starting pore waters, representing, at any given time interval, the closest occurrence to the drift of liquid water in the host rock. The thermal-hydrological-chemical model output is then abstracted to a subset of 368 water compositions representing the chemical evolution of the five starting waters as a function of location (the invert and the crown) through time. The selection of these waters is documented in Post-Processing Analysis of THC Seepage (BSC 2004 [DIRS 169858], Section 6.2.3.3), and in Engineered Barrier System: Physical and Chemical Environment (BSC 2005 [DIRS 175083], Section 6.6). 
The subset of 368 water compositions from the thermal-hydrological-chemical seepage model gives equal probability to the five starting pore water compositions, and serves as seepage water inputs for in-drift chemistry modeling. As documented in Engineered Barrier System: Physical and Chemical Environment (BSC 2005 [DIRS 175083], Section 6.6), these waters were grouped into 11 bins, according to a "normalized" chemistry determined by using geochemical modeling (EQ3/6) to simulate evaporation of the waters to a fixed activity of water. A representative water composition for each bin was chosen using a ranking algorithm. The representative bin waters were mapped back to the seepage water evolution histories for each of the 5 starting waters to create "bin history maps." Lookup tables were then created for each of the representative bin waters by simulating evaporation of the waters under a range of temperature and partial pressures of $\mathrm{CO}_{2}$ to produce a suite of possible in-drift water compositions (BSC 2005 [DIRS 175083], Section 6.9). These lookup tables are used to determine an incoming crown and invert water composition for performance assessment by randomly choosing one of the five starting waters and using the appropriate bin history map to determine the applicable bin. The predicted temperature and partial pressure of $\mathrm{CO}_{2}$ in the drift is then used to determine the appropriate lookup table for that bin water, and the water composition is determined as a function of predicted relative humidity in the drift (BSC 2005 [DIRS 175083], Sections 6.6 and 6.13).

Thus, predicted in-drift water compositions are derived from the abstracted thermalhydrological-chemical seepage waters, and include the effects of precipitation and redissolution of precipitates in the host rock during and after the thermal dryout.

\section{Supporting Documents:}

BSC 2005 [DIRS 175083]

BSC 2005 [DIRS 172862]

BSC 2004 [DIRS 169858]

\subsubsection{Seismic-Induced Drift Collapse Alters In-Drift Chemistry}

\section{FEP Number:}

1.2.03.02.0E

FEP Description: Seismic activity could produce jointed-rock motion and/or changes in rock stress leading to enhanced drift collapse and/or rubble infill throughout part or all of the drifts. Drift collapse, and the associated changes in seepage and in-drift thermohydrology could impact in-drift chemistry.

\section{Screening Decision:}

Excluded (Low Consequence)

Screening Argument: Rockfall induced by vibratory ground motion can alter the hydrologic and thermal environment in the drifts after the seismic event. The potential changes in the in-drift environment after a seismic event are discussed in Seismic Consequence Abstraction (BSC 2005 [DIRS 173247], Section 6.8) and addressed in the seismic scenario class for TSPA-LA, as discussed in Section 6.2.11 of the current report under FEP 1.2.03.02.0D.

The collapse of drifts from high amplitude ground motion in the lithophysal zones can alter the shape of the original opening and fill it with a natural backfill, potentially changing the 
hydrologic and thermal environment around EBS components. These changes can affect a variety of processes:

- Seepage may increase because an irregular drift shape reduces the effectiveness of the drift wall as a capillary barrier and because of a loosening of the fractures around the drift.

- Temperature of the drip shield and waste package may increase relative to an unfilled drift because the backfill provides an insulating blanket on top of the drip shield.

- Localized corrosion may increase because of increased temperature and because of rock and water contact with the drip shield or waste package.

- The dissolution rates of CSNF and HLW glass increase with temperature.

In the nonlithophysal zones, complete drift collapse is not observed for ground motion amplitudes at or below the $5.35 \mathrm{~m} / \mathrm{s}$ PGV level (BSC 2004 [DIRS 166107], Section 6.3.1.6.4). Since the $5.35 \mathrm{~m} / \mathrm{s}$ PGV level is beyond the maximum PGV value of $4.07 \mathrm{~m} / \mathrm{s}$ that is expected at the repository horizon (BSC 2005 [DIRS 173247], Section 6.4.3), complete collapse of drifts with the associated en masse fall of rock is not expected to occur. In this situation, drift collapse in nonlithophysal rock is neglected in the seismic scenario class for TSPA on this basis.

The general configuration of the drip shield positioned over the waste packages will endure through a seismic event, as discussed in Seismic Consequence Abstraction (BSC 2005 [DIRS 173247], Section 6.5.5) and in Section 6.2.8 of the present document under FEP 1.2.03.02.0A.

The chemistry of in-drift chemistry is predicted, depending upon the scenario, as a function of incoming seepage water, the local conditions of temperature, relative humidity, and in-drift partial pressure of carbon dioxide, as discussed in Engineered Barrier System: Physical and Chemical Environment (BSC 2005 [DIRS 175083], Section 6.9).

The influence of a low-probability collapsed-drift scenario on in-drift temperature and relative humidity is considered in Multiscale Thermohydrologic Model (BSC 2005 [DIRS 173944], Section 6.3.7) and in Section 6.2.11 of the current document under FEP 1.2.03.02.0D. Changes to several MSTHM submodels are required to simulate the influence of drift collapse (BSC 2005 [DIRS 173944], Section 6.3.7). For such a collapse, a rubble-filled drift would exist. The thermal conductivity and relative density (or porosity) will derive from the size distribution of collapsed material. The MSTHM provides an implementation of the collapsed drift scenario to TSPA-LA as changes in the temperature and relative humidity relative to base-case results. Specifically, the low-probability seismic scenario implements a $\Delta \mathrm{T}$ and $\Delta \mathrm{RH}$ for realizations that include a drift collapse, as described in Seismic Consequence Abstraction (BSC 2005 [DIRS 173247], Section 6.8.2). These changes to temperature and relative humidity are applied to the base case so that the influence of these changes will be reflected in the prediction of in-drift chemistry. 
The degradation mode for the drip shield is general corrosion and the rates are based on weight loss measurements made in a laboratory. As discussed in General Corrosion and Localized Corrosion of the Drip Shield (BSC 2004 [DIRS 169845], Section 8.3), no differentiation is made between the humid-air corrosion and aqueous-phase corrosion. Thus the presence of the collapsed drift rubble in contact with the drip shield will not influence predictions of drip shield degradation. The composition of dust on waste packages would not be chemically altered in the event of a drift collapse, as the drip shield protects the waste packages. Thus predictions of corrosion due to dust deliquescence will remain valid.

The effect of drift collapse on potential seepage compositions has been analyzed in Abstraction of Drift-Scale Processes (BSC 2004 [DIRS 169617]). This report concludes that the predicted chemistries resulting from drift degradation are comparable in the spread in THC model seepage chemistry results evaluated for various ranges of input parameters and water compositions for an intact drift (BSC 2004 [DIRS 169617], Section 8.2).

Multiscale Thermohydrologic Model (BSC 2005 [DIRS 173944], Section 6.3.7.1) describes the postseismic changes in the in-drift environment (impacts to temperature and relative humidity) for the seismic scenario class. Operation 13 in Seismic Consequence Abstraction (BSC 2005 [DIRS 173247], Section 6.9.2) provides the instructions for accounting for post seismic event changes related to adjusting temperature and relative humidity in TSPA.

In summary, omission of the impact of collapsed drift on predictions of in-drift chemistry from the TSPA-LA will not have a significant effect on the magnitude and time of the resulting radiological exposures to the RMEI or radionuclide releases to the accessible environment.

TSPA Disposition:

N/A

Supporting Documents:

N/A 
INTENTIONALLY LEFT BLANK 


\section{CONCLUSIONS}

Table 7-1 provides a summary of the conclusions (i.e., excluded EBS FEP screening decisions) and the basis for Exclude decisions. The screening arguments described in this table have been made in accordance with the criteria outlined in Section 4.1.3 of this report. Treatment of uncertainty is not explicitly discussed for excluded FEPs because the exclusion rationale and associated arguments are sufficiently bounding to account for reasonable uncertainties of relevant phenomena. The documentation of uncertainty for included FEPs is in the cited documents.

Table 7-1. Summary of EBS FEPs Screening Decisions

\begin{tabular}{|c|c|c|c|}
\hline FEP Number & FEP Name & Screening Decision & $\begin{array}{l}\text { Addressed in } \\
\text { Section }\end{array}$ \\
\hline 1.1.02.00.0A & Chemical effects of excavation and construction in EBS & $\begin{array}{c}\text { Excluded } \\
\text { (Low Consequence) }\end{array}$ & 6.2.1 \\
\hline 1.1.02.00.0B & Mechanical effects of excavation and construction in EBS & $\begin{array}{c}\text { Excluded } \\
\text { (Low Consequence) }\end{array}$ & 6.2 .2 \\
\hline 1.1.02.02.0A & Preclosure ventilation & Included & 6.2 .3 \\
\hline 1.1.02.03.0A & Undesirable materials left & $\begin{array}{c}\text { Excluded } \\
\text { (Low Consequence) }\end{array}$ & 6.2 .4 \\
\hline 1.1.03.01.0A & Error in waste emplacement & $\begin{array}{c}\text { Excluded } \\
\text { (Low Consequence) }\end{array}$ & 6.2 .5 \\
\hline 1.1.03.01.0B & Error in backfill emplacement & $\begin{array}{c}\text { Excluded } \\
\text { (Low Probability) }\end{array}$ & 6.2.6 \\
\hline 1.2.02.03.0A & Fault displacement damages EBS components & Included & 6.2 .7 \\
\hline 1.2.03.02.0A & Seismic ground motion damages EBS components & Included & 6.2 .8 \\
\hline 1.2.03.02.0B & Seismic-induced rockfall damages EBS components & $\begin{array}{c}\text { Excluded } \\
\text { (Low Consequence) }\end{array}$ & 6.2 .9 \\
\hline 1.2.03.02.0C & Seismic-induced drift collapse damages EBS components & $\begin{array}{c}\text { Excluded } \\
\text { (Low Consequence) }\end{array}$ & 6.2 .10 \\
\hline 1.2.03.02.0D & $\begin{array}{l}\text { Seismic-induced drift collapse alters in-drift } \\
\text { thermohydrology }\end{array}$ & Included & 6.2 .11 \\
\hline 1.2.03.02.0E & Seismic-induced drift collapse alters in-drift chemistry & $\begin{array}{c}\text { Excluded } \\
\text { (Low Consequence) }\end{array}$ & 6.2 .90 \\
\hline 2.1.03.10.0A & $\begin{array}{l}\text { Advection of liquids and solids through cracks in waste } \\
\text { package }\end{array}$ & $\begin{array}{c}\text { Excluded } \\
\text { (Low Consequence) }\end{array}$ & 6.2 .63 \\
\hline 2.1.03.10.0B & $\begin{array}{l}\text { Advection of liquids and solids through cracks in drip } \\
\text { shield }\end{array}$ & $\begin{array}{c}\text { Excluded } \\
\text { (Low Consequence) }\end{array}$ & 6.2 .64 \\
\hline 2.1.04.01.0A & Flow in the backfill & $\begin{array}{c}\text { Excluded } \\
\text { (Low Probability) }\end{array}$ & 6.2 .12 \\
\hline 2.1.04.02.0A & Chemical properties and evolution of backfill & $\begin{array}{c}\text { Excluded } \\
\text { (Low Probability) }\end{array}$ & 6.2 .13 \\
\hline 2.1.04.03.0A & Erosion or dissolution of backfill & $\begin{array}{c}\text { Excluded } \\
\text { (Low Probability) }\end{array}$ & 6.2 .14 \\
\hline 2.1.04.04.0A & Thermal-mechanical effects of backfill & $\begin{array}{c}\text { Excluded } \\
\text { (Low Probability) }\end{array}$ & 6.2 .15 \\
\hline 2.1.04.05.0A & Thermal-mechanical properties and evolution of backfill & $\begin{array}{c}\text { Excluded } \\
\text { (Low Probability) }\end{array}$ & 6.2 .16 \\
\hline 2.1.04.09.0A & Radionuclide transport in backfill & $\begin{array}{c}\text { Excluded } \\
\text { (Low Probability) }\end{array}$ & 6.2 .17 \\
\hline
\end{tabular}


Table 7-1. Summary of EBS FEPs Screening Decisions (Continued)

\begin{tabular}{|c|c|c|c|}
\hline FEP Number & FEP Name & Screening Decision & $\begin{array}{l}\text { Addressed in } \\
\text { Section }\end{array}$ \\
\hline 2.1.06.01.0A & $\begin{array}{l}\text { Chemical effects of rock reinforcement and cementitious } \\
\text { materials in EBS }\end{array}$ & $\begin{array}{c}\text { Excluded } \\
\text { (Low Consequence) }\end{array}$ & 6.2 .18 \\
\hline 2.1.06.02.0A & Mechanical effects of rock reinforcement materials in EBS & $\begin{array}{c}\text { Excluded } \\
\text { (Low Consequence) }\end{array}$ & 6.2 .19 \\
\hline 2.1.06.04.0A & Flow through rock reinforcement materials in EBS & $\begin{array}{c}\text { Excluded } \\
\text { (Low Consequence) }\end{array}$ & 6.2 .20 \\
\hline 2.1.06.05.0A & Mechanical degradation of emplacement pallet & $\begin{array}{c}\text { Excluded } \\
\text { (Low Consequence) }\end{array}$ & 6.2 .21 \\
\hline 2.1.06.05.0B & Mechanical degradation of invert & $\begin{array}{c}\text { Excluded } \\
\text { (Low Consequence) }\end{array}$ & 6.2 .22 \\
\hline $2.1 .06 .05 .0 \mathrm{C}$ & Chemical degradation of emplacement pallet & $\begin{array}{c}\text { Excluded } \\
\text { (Low Consequence) }\end{array}$ & 6.2 .23 \\
\hline 2.1.06.05.0D & Chemical degradation of invert & $\begin{array}{c}\text { Excluded } \\
\text { (Low Consequence) }\end{array}$ & 6.2 .24 \\
\hline 2.1.06.06.0A & Effects of drip shield on flow & Included & 6.2 .25 \\
\hline 2.1.06.07.0A & Chemical effects at EBS component interfaces & $\begin{array}{c}\text { Excluded } \\
\text { (Low Consequence) }\end{array}$ & 6.2 .26 \\
\hline 2.1.06.07.0B & Mechanical effects at EBS component interfaces & $\begin{array}{c}\text { Excluded } \\
\text { (Low Consequence) } \\
\end{array}$ & 6.2 .27 \\
\hline 2.1.07.01.0A & Rockfall & $\begin{array}{c}\text { Excluded } \\
\text { (Low Consequence) }\end{array}$ & 6.2 .28 \\
\hline $2.1 .07 .02 .0 \mathrm{~A}$ & Drift collapse & $\begin{array}{c}\text { Excluded } \\
\text { (Low Consequence) }\end{array}$ & 6.2 .29 \\
\hline $2.1 .07 .04 .0 \mathrm{~A}$ & Hydrostatic pressure on waste package & $\begin{array}{c}\text { Excluded } \\
\text { (Low Probability) }\end{array}$ & 6.2 .30 \\
\hline 2.1.07.04.0B & Hydrostatic pressure on drip shield & $\begin{array}{c}\text { Excluded } \\
\text { (Low Probability) }\end{array}$ & 6.2 .31 \\
\hline 2.1.07.06.0A & Floor buckling & $\begin{array}{c}\text { Excluded } \\
\text { (Low Consequence) }\end{array}$ & 6.2 .32 \\
\hline 2.1.08.01.0B & Effects of rapid influx into the repository & $\begin{array}{c}\text { Excluded } \\
\text { (Low Consequence) }\end{array}$ & 6.2 .33 \\
\hline 2.1.08.03.0A & Repository dry-out due to waste heat & Included & 6.2 .34 \\
\hline 2.1.08.04.0A & $\begin{array}{l}\text { Condensation forms on roofs of drifts (drift-scale cold } \\
\text { traps) }\end{array}$ & Included & 6.2 .35 \\
\hline 2.1.08.04.0B & $\begin{array}{l}\text { Condensation forms at repository edges (repository-scale } \\
\text { cold traps) }\end{array}$ & Included & 6.2 .36 \\
\hline 2.1.08.05.0A & Flow through invert & Included & 6.2 .37 \\
\hline $2.1 .08 .06 .0 \mathrm{~A}$ & Capillary effects (wicking) in EBS & Included & 6.2 .38 \\
\hline $2.1 .08 .07 .0 \mathrm{~A}$ & Unsaturated flow in the EBS & Included & 6.2 .39 \\
\hline 2.1.08.09.0A & Saturated flow in the EBS & $\begin{array}{c}\text { Excluded } \\
\text { (Low Consequence) }\end{array}$ & 6.2 .40 \\
\hline $2.1 .08 .11 .0 \mathrm{~A}$ & Repository resaturation due to waste cooling & Included & 6.2 .41 \\
\hline 2.1.08.12.0A & Induced hydrologic changes in invert & $\begin{array}{c}\text { Excluded } \\
\text { (Low Consequence) }\end{array}$ & 6.2 .42 \\
\hline 2.1.08.14.0A & Condensation on underside of drip shield & $\begin{array}{l}\text { Excluded } \\
\text { (Low Consequence) }\end{array}$ & 6.2 .43 \\
\hline
\end{tabular}


Table 7-1. Summary of EBS FEPs Screening Decisions (Continued)

\begin{tabular}{|c|c|c|c|}
\hline FEP Number & FEP Name & Screening Decision & $\begin{array}{l}\text { Addressed in } \\
\text { Section }\end{array}$ \\
\hline 2.1.08.15.0A & Consolidation of EBS components & $\begin{array}{c}\text { Excluded } \\
\text { (Low Consequence) }\end{array}$ & 6.2 .44 \\
\hline 2.1.09.01.0A & Chemical characteristics of water in drifts & Included & 6.2 .45 \\
\hline 2.1.09.02.0A & Chemical interaction with corrosion products & Included & 6.2 .46 \\
\hline 2.1.09.03.0C & $\begin{array}{l}\text { Volume increase of corrosion products impacts other EBS } \\
\text { components }\end{array}$ & $\begin{array}{c}\text { Excluded } \\
\text { (Low Consequence) }\end{array}$ & 6.2 .47 \\
\hline 2.1.09.05.0A & Sorption of dissolved radionuclides in EBS & Included & 6.2 .48 \\
\hline 2.1.09.06.0B & Reduction-oxidation potential in drifts & Included & 6.2 .49 \\
\hline 2.1.09.07.0B & Reaction kinetics in drifts & Included & 6.2 .50 \\
\hline 2.1.09.08.0A & Diffusion of dissolved radionuclides in EBS & Included & 6.2 .51 \\
\hline 2.1.09.08.0B & Advection of dissolved radionuclides in EBS & Included & 6.2 .52 \\
\hline 2.1.09.19.0A & Sorption of colloids in EBS & $\begin{array}{c}\text { Excluded } \\
\text { (Low Consequence) }\end{array}$ & 6.2 .53 \\
\hline 2.1.09.19.0B & Advection of colloids in EBS & Included & 6.2 .54 \\
\hline 2.1.09.20.0A & Filtration of colloids in EBS & $\begin{array}{c}\text { Excluded } \\
\text { (Low Consequence) }\end{array}$ & 6.2 .55 \\
\hline 2.1.09.21.0A & Transport of particles larger than colloids in EBS & $\begin{array}{c}\text { Excluded } \\
\text { (Low Consequence) } \\
\end{array}$ & 6.2 .56 \\
\hline 2.1.09.22.0A & Sorption of colloids at air-water interface & $\begin{array}{c}\text { Excluded } \\
\text { (Low Consequence) }\end{array}$ & 6.2 .57 \\
\hline 2.1.09.24.0A & Diffusion of colloids in EBS & Included & 6.2 .58 \\
\hline 2.1.09.26.0A & Gravitational settling of colloids in EBS & $\begin{array}{c}\text { Excluded } \\
\text { (Low Consequence) }\end{array}$ & 6.2 .59 \\
\hline 2.1.09.27.0A & Coupled effects on radionuclide transport in EBS & $\begin{array}{c}\text { Excluded } \\
\text { (Low Consequence) }\end{array}$ & 6.2 .60 \\
\hline 2.1.09.28.0A & $\begin{array}{l}\text { Localized corrosion on waste package outer surface due } \\
\text { to deliquescence }\end{array}$ & $\begin{array}{c}\text { Excluded } \\
\text { (Low Consequence) }\end{array}$ & 6.2 .61 \\
\hline 2.1.09.28.0B & $\begin{array}{l}\text { Localized corrosion on drip shield surfaces due to } \\
\text { deliquescence }\end{array}$ & $\begin{array}{c}\text { Excluded } \\
\text { (Low Consequence) } \\
\end{array}$ & 6.2 .62 \\
\hline 2.1.10.01.0A & Microbial activity in EBS & $\begin{array}{c}\text { Excluded } \\
\text { (Low Consequence) }\end{array}$ & 6.2 .65 \\
\hline 2.1.11.01.0A & Heat generation in EBS & Included & 6.2 .66 \\
\hline 2.1.11.02.0A & Non-uniform heat distribution in EBS & Included & 6.2 .67 \\
\hline 2.1.11.03.0A & Exothermic reactions in the EBS & $\begin{array}{c}\text { Excluded } \\
\text { (Low Consequence) }\end{array}$ & 6.2 .68 \\
\hline 2.1.11.07.0A & Thermal expansion/stress of in-drift EBS components & $\begin{array}{c}\text { Excluded } \\
\text { (Low Consequence) }\end{array}$ & 6.2 .69 \\
\hline 2.1.11.08.0A & $\begin{array}{l}\text { Thermal effects on chemistry and microbial activity in the } \\
\text { EBS }\end{array}$ & Included & 6.2 .70 \\
\hline 2.1.11.09.0A & Thermal effects on flow in the EBS & Included & 6.2 .71 \\
\hline 2.1.11.09.0C & Thermally-driven flow (convection) in drifts & Included & 6.2 .72 \\
\hline 2.1.11.10.0A & Thermal effects on transport in EBS & $\begin{array}{c}\text { Excluded } \\
\text { (Low Consequence) }\end{array}$ & 6.2 .73 \\
\hline 2.1.12.01.0A & Gas generation (repository pressurization) & $\begin{array}{c}\text { Excluded } \\
\text { (Low Consequence) }\end{array}$ & 6.2 .74 \\
\hline
\end{tabular}


Table 7-1. Summary of EBS FEPs Screening Decisions (Continued)

\begin{tabular}{|c|c|c|c|}
\hline FEP Number & FEP Name & Screening Decision & $\begin{array}{l}\text { Addressed in } \\
\text { Section }\end{array}$ \\
\hline 2.1.12.02.0A & Gas generation $(\mathrm{He})$ from waste form decay & $\begin{array}{c}\text { Excluded } \\
\text { (Low Consequence) }\end{array}$ & 6.2 .75 \\
\hline 2.1.12.03.0A & Gas generation $\left(\mathrm{H}_{2}\right)$ from waste package corrosion & $\begin{array}{c}\text { Excluded } \\
\text { (Low Consequence) }\end{array}$ & 6.2 .76 \\
\hline 2.1.12.04.0A & $\begin{array}{l}\text { Gas generation }\left(\mathrm{CO}_{2}, \mathrm{CH}_{4}, \mathrm{H}_{2} \mathrm{~S}\right) \text { from microbial } \\
\text { degradation }\end{array}$ & $\begin{array}{c}\text { Excluded } \\
\text { (Low Consequence) }\end{array}$ & 6.2 .77 \\
\hline 2.1.12.06.0A & Gas transport in EBS & $\begin{array}{c}\text { Excluded } \\
\text { (Low Consequence) }\end{array}$ & 6.2 .78 \\
\hline 2.1.12.07.0A & Effects of radioactive gases in EBS & $\begin{array}{c}\text { Excluded } \\
\text { (Low Consequence) }\end{array}$ & 6.2 .79 \\
\hline 2.1.12.08.0A & Gas explosions in EBS & $\begin{array}{c}\text { Excluded } \\
\text { (Low Probability) }\end{array}$ & 6.2 .80 \\
\hline 2.1.13.01.0A & Radiolysis & $\begin{array}{c}\text { Excluded } \\
\text { (Low Consequence) }\end{array}$ & 6.2 .81 \\
\hline 2.1.13.02.0A & Radiation damage in EBS & $\begin{array}{c}\text { Excluded } \\
\text { (Low Consequence) }\end{array}$ & 6.2 .82 \\
\hline 2.1.13.03.0A & Radiological mutation of microbes & $\begin{array}{c}\text { Excluded } \\
\text { (Low Consequence) }\end{array}$ & 6.2 .83 \\
\hline 2.2.01.02.0A & Thermally-induced stress changes in the near-field & $\begin{array}{c}\text { Excluded } \\
\text { (Low Consequence) }\end{array}$ & 6.2 .84 \\
\hline 2.2.01.02.0B & Chemical changes in the near-field from backfill & $\begin{array}{c}\text { Excluded } \\
\text { (Low probability) }\end{array}$ & 6.2 .85 \\
\hline 2.2.07.06.0A & Episodic or pulse release from repository & $\begin{array}{c}\text { Excluded } \\
\text { (Low Consequence) }\end{array}$ & 6.2 .86 \\
\hline 2.2.07.06.0B & Long-term release of radionuclides from the repository & Included & 6.2 .87 \\
\hline 2.2.07.21.0A & Drift shadow forms below repository & $\begin{array}{c}\text { Excluded } \\
\text { (Low Consequence) }\end{array}$ & 6.2 .88 \\
\hline 2.2.08.04.0A & $\begin{array}{l}\text { Re-dissolution of precipitates directs more corrosive fluids } \\
\text { to waste packages }\end{array}$ & Included & 6.2 .89 \\
\hline
\end{tabular}

The conclusions from this document (FEP Screening Decision, TSPA Disposition for included FEPs, or Screening Argument for excluded FEPs) are expected to be incorporated in the Yucca Mountain TSPA-LA FEP database. There are no restrictions on this use. The FEP database is designed to contain all Yucca Mountain FEPs considered for TSPA-LA with FEP number, name, description, and citations to relevant FEP analysis reports where the documentation of the screening of specific FEPs is summarized. The FEP database will also contain screening decisions (Include or Exclude), screening arguments, and TSPA dispositions quoted from this and all other FEP analysis reports. 


\subsection{SATISFACTION OF ACCEPTANCE CRITERIA}

The YMRP acceptance criteria (NRC 2003 [DIRS 163274]) relevant to EBS FEPs as described in this document are listed in Section 4.2.2. This section summarizes how the disposition of FEPs in this document addresses the criteria.

\subsubsection{Acceptance Criteria from Section 4.2.2.1 of This Report and Section 2.2.1.2.1.3 of Yucca Mountain Review Plan, Final Report (NRC 2003 [DIRS 163274]), Scenario Analysis and Event Probability}

Acceptance Criterion 1: The Identification of a List of Features, Events, and Processes Is Adequate.

(1) The Safety Analysis Report contains a complete list of features, events, and processes, related to the geologic setting or the degradation, deterioration, or alteration of engineered barriers (including those processes that would affect the performance of natural barriers), that have the potential to influence repository performance. The list is consistent with the site characterization data. Moreover, the comprehensive features, events, and processes list includes, but is not limited to, potentially disruptive events related to igneous activity (extrusive and intrusive); seismic shaking (high-frequency-low magnitude, and rare large-magnitude events); tectonic evolution (slip on existing faults and formation of new faults); climatic change (change to pluvial conditions); and criticality.

This criterion is addressed in The Development of the Total System Performance Assessment-License Application Features, Events, and Processes (BSC 2005 [DIRS 173800], Section 2) and is summarized here. The overall FEP list was initially developed from a comprehensive set of general issues from radioactive waste disposal programs in several other countries. From this a set of YMP-specific issues was developed from documents that identify issues unique to the YMP design and setting. The 90 FEPs included in this document are a subset of the overall YMP-specific list and are relevant to features, events, and processes in the Engineered Barrier System.

Acceptance Criterion 2: Screening of the List of Features, Events, and Processes Is Appropriate.

(1) The U.S. Department of Energy has identified all features, events, and processes related to either the geologic setting or to the degradation, deterioration, or alteration of engineered barriers (including those processes that would affect the performance of natural barriers) that have been excluded.

A comprehensive list of FEPs specific to the Yucca Mountain Project is located in the LA FEP List and Screening (DTN: MO0501SEPFEPLA.001 [DIRS 172601]). From this list of YMP-specific FEPs, a subset of 90 was identified as relating to the EBS. These 90 FEPs have been screened, and excluded FEPs have been identified. A list of the 90 FEPs is given in Table 1-1. The screening arguments are provided in Section 6.2. Deviations in two FEP titles and descriptions in DTN: MO0501SEPFEPLA.001 [DIRS 172601] are documented in Technical Management Review Board (TMRB) Decision Proposal (TMRB-2005-047) 
(BSC 2005 [DIRS 174965]), and Technical Management Review Board (TMRB) Decision Proposal (TMRB-2005-050) (BSC 2005 [DIRS 174990]).

(2) The U.S. Department of Energy has provided justification for those features, events, and processes that have been excluded. An acceptable justification for excluding features, events, and processes is that either the feature, event, and process is specifically excluded by regulation; probability of the feature, event, and process (generally an event) falls below the regulatory criterion; or omission of the feature, event, and process does not significantly change the magnitude and time of the resulting radiological exposures to the reasonably maximally exposed individual, or radionuclide releases to the accessible environment.

Each FEP was evaluated against regulatory-based screening criteria (Section 4.2.3) and documented with a screening decision; a screening argument was developed for excluded FEPs, and a TSPA disposition was developed for included FEPs. A FEP that satisfied any one of the exclusion screening criteria (low probability, low consequence, or by regulation) was excluded from TSPA-LA. A FEP that did not satisfy any of the exclusion screening criteria was included in the TSPA-LA model. The results are presented in Section 6.2 and in Table 7-1 along with their inclusion or exclusion status.

(3) The U.S. Department of Energy has provided an adequate technical basis for each feature, event, and process, excluded from the performance assessment, to support the conclusion that either the feature, event, or process is specifically excluded by regulation; the probability of the feature, event, and process falls below the regulatory criterion; or omission of the feature, event, and process does not significantly change the magnitude and time of the resulting radiological exposures to the reasonably maximally exposed individual, or radionuclide releases to the accessible environment.

The technical bases for the screening decision of each excluded FEP are presented in Section 6.2. Table 7.1 provides the identification of those FEPs that are excluded from the TSPA-LA.

\subsubsection{Acceptance Criteria from Section 4.2.2.2 of This Report and Section 2.2.1.3.3.3 of Yucca Mountain Review Plan, Final Report (NRC 2003 [DIRS 163274]), Quantity and Chemistry of Water Contacting Engineered Barriers and Waste Forms}

Acceptance Criterion 1: System Description and Model Integration Are Adequate.

(1) Total system performance assessment adequately incorporates important design features, physical phenomena, and couplings, and uses consistent and appropriate assumptions throughout the quantity and chemistry of water contacting engineered barriers and waste forms abstraction process;

Design features, repository configuration, and associated physical phenomena concerning the quantity and chemistry of water contacting engineered barriers that are passed on to TSPA are developed in multiple subsections of Section 6.2. These include Sections 6.2.18 through 6.2.26, 6.2.35 through 6.2.39, 6.2.41, 6.2.43, 6.2.45, 6.2.48 through 6.2.64, 6.2.70 through 6.2.73, 6.2.87, and 6.2.89. Coupled processes are addressed in Section 6.2.60 of this report. 
(2) The abstraction of the quantity and chemistry of water contacting engineered barriers and waste forms uses assumptions, technical bases, data, and models that are appropriate and consistent with other related DOE abstractions. For example, the assumptions used for the quantity and chemistry of water contacting engineered barriers and waste forms are consistent with the abstractions of "Degradation of Engineered Barriers" (Section 2.2.1.3.1); "Mechanical Disruption of Engineered Barriers" (Section 2.2.1.3.2); "Radionuclide Release Rates and Solubility Limits" (Section 2.2.1.3.4); "Climate and Infiltration" (Section 2.2.1.3.5); and "Flow Paths in the Unsaturated Zone" (Section 2.2.1.3.6). The descriptions and technical bases provide transparent and traceable support for the abstraction of quantity and chemistry of water contacting engineered barriers and waste forms;

Abstractions of the quantity and chemistry of water contacting engineered barriers that are appropriate and consistent with other related U.S. Department of Energy abstractions are found in subsections of Section 6.2 of this report. Specifically, Sections 6.2.18, 6.2.23, 6.2.24, and 6.2.26 of this report are appropriate and consistent with "Degradation of Engineered Barriers" (Section 2.2.1.3.1 of the YMRP). Sections 6.2.21, 6.2.22, and 6.2.27 of this report are appropriate and consistent with "Mechanical Disruption of Engineered Barriers" (Section 2.2.1.3.2 of the YMRP). Sections 6.2.18, 6.2.23, 6.2.24, 6.2.45, 6.2.46, 6.2.48 through $6.2 .60,6.2 .63,6.2 .64$, and 6.2 .87 of this report are appropriate and consistent with "Radionuclide Release Rates and Solubility Limits" (Section 2.2.1.3.4 of the YMRP).

The quantity and chemistry of water contacting engineered barriers and its relation to "Climate and Infiltration" (Section 2.2.1.3.5); and "Flow Paths in the Unsaturated Zone" (Section 2.2.1.3.6) are not specifically covered by this report. Instead these issues are covered by FEPs arguments in Features, Events and Processes in UZ Flow and Transport (BSC 2005 [DIRS 174191]).

(3) Important design features, such as waste package design and material selection, backfill, drip shield, ground support, thermal loading strategy, and degradation processes, are adequate to determine the initial and boundary conditions for calculations of the quantity and chemistry of water contacting engineered barriers and waste forms;

Important design features, such as drip shield, ground support, and degradation processes are considered and described in the following sections of this report: 6.2.11, 6.2.18 through 6.2.29, 6.2.31, 6.2.35, 6.2.37 and 6.2.38, 6.2.42 and 6.2.43, 6.2.46 and 6.2.47, 6.2.61 through 6.2.64, 6.2.71, 6.2.82, and 6.2.84.

Backfill is no longer a repository design element, so that the quantity and chemistry of water contacting engineered barriers is no longer a design consideration. Therefore, these FEP arguments are excluded in Sections 6.2.6, 6.2.12 through 6.2.17, and 6.2.85 of this report.

Other design features not specifically discussed in these FEPs, such as waste package design, material selection, and thermal loading strategy, are provided in the model and analysis report documents to be consistent with current design bases. These are located in Section 4 of the 
various reports cited as supporting documents that describe the disposition of the FEPs evaluated in this report.

(4) Spatial and temporal abstractions appropriately address physical couplings (thermalhydrological-mechanical-chemical). For example, DOE evaluates the potential for focusing of water flow into drifts, caused by coupled thermal-hydrologicalmechanical-chemical processes;

Thermal, hydrological, mechanical, and chemical processes are addressed by most of the FEPs throughout Section 6.2. Coupled effects are specifically addressed in Section 6.2.60 in the context of coupled effects on radionuclide transport.

(6) The expected ranges of environmental conditions within the waste package emplacement drifts, inside of breached waste packages, and contacting the waste forms and their evolution with time are identified. These ranges may be developed to include:

(i) the effects of the drip shield and backfill on the quantity and chemistry of water (e.g., the potential for condensate formation and dripping from the underside of the shield);

(ii) conditions that promote corrosion of engineered barriers and degradation of waste forms;

(iii) irregular wet and dry cycles;

(iv) gamma-radiolysis; and

(v) size and distribution of penetrations of engineered barriers;

The effects specifically of the drip shield on water quantity and chemistry are addressed in Sections 6.2.25, 6.2.31, 6.2.43, 6.2.62, and 6.2.64. Backfill is no longer a part of the repository design, and backfill effects are therefore not considered. Numerous FEPs address conditions that may promote corrosion of engineered barriers and degradation of waste forms, including those addressed in Sections 6.2.18, 6.2.23, 6.2.24, 6.2.26, 6.2.45, 6.2.46, 6.2.49, 6.2.50, 6.2.61, 6.2.62, $6.2 .65,6.2 .70,6.2 .81,6.2 .82,6.2 .89$, and 6.2.90.

"Irregular wet and dry cycles" relates primarily to the drying out of the repository soon after closure and to water reflux during cool down, but also to localized effects, such as condensation of water vapor in "cold traps." Relevant sections include 6.2.33, 6.2.34, 6.2.35, 6.2.36, 6.2.38, and 6.2.41. Gamma radiolysis is addressed in Section 6.2.81. Size and distribution of penetrations of engineered barriers are discussed mainly in the context of stress corrosion cracks. Relevant sections include 6.2.63 and 6.2.64.

(8) Adequate technical bases are provided, including activities such as independent modeling, laboratory or field data, or sensitivity studies, for inclusion of any thermalhydrologic-mechanical-chemical couplings and features, events, and processes; 
Thermal, hydrological, mechanical, and chemical processes are addressed by most of the 90 FEPs addressed in Section 6.2. Collectively, the FEPs presented in Section 6.2 address the modeling of coupled thermal-hydrologic-mechanical-chemical effects on seepage and flow, the EBS physical and chemical environment, and radionuclide transport. Individually, the FEPs address specific phenomena and their effects on specific EBS components. Coupled processes relative to radionuclide transport are covered in Section 6.2.60. The FEPs were addressed by reference to several reports (listed in Section 8.1) that analyze individual and coupled phenomena at drift and repository scales.

(9) Performance-affecting processes that have been observed in thermal-hydrologic tests and experiments are included into the performance assessment. For example, the U.S. Department of Energy either demonstrates that liquid water will not reflux into the underground facility or incorporates refluxing water into the performance assessment calculation, and bounds the potential adverse effects of alteration of the hydraulic pathway that result from refluxing water;

Most of the FEPs presented in Section 6.2 relate to performance-affecting processes that have been observed in thermal-hydrologic tests, either in the laboratory, in pilot-scale tests, or in field tests. Processes that were not screened out have been incorporated into the TSPA-LA model.

\section{Acceptance Criterion 2: Data Are Sufficient for Model Justification.}

(4) Sufficient information to formulate the conceptual approach(es) for analyzing water contact with the drip shield, engineered barriers, and waste forms is provided;

Considerable information has been provided to formulate the conceptual approach(es) for analyzing water contact with the drip shield, engineered barriers, and waste forms. FEPs in Section 6.2 that address water contact with the EBS components include those presented in Sections 6.2.20, 6.2.25, 6.2.30, 6.2.31, 6.2.33 through 6.3.43, 6.2.45, 6.2.46, 6.2.49, 6.2.51, 6.2.52, 6.2.61, 6.2.62, 6.2.63, and 6.2.64. These FEPs address several aspects of water movement and contact, including saturated and unsaturated flow; condensation, dripping, and wicking; effects of waste heating and cooling; and water contact with EBS components and components' effects on flow. Additional FEPs in this report deal with other aspects of water in the drift, including water chemistry and radionuclide transport. 


\section{INTENTIONALLY LEFT BLANK}




\section{INPUTS AND REFERENCES}

\subsection{DOCUMENTS CITED}

101367 Albin, A.L.; Singleton, W.L.; Moyer, T.C.; Lee, A.C.; Lung, R.C.; Eatman, G.L.W.; and Barr, D.L. 1997. Geology of the Main Drift - Station 28+00 to 55+00, Exploratory Studies Facility, Yucca Mountain Project, Yucca Mountain, Nevada. Milestone SPG42AM3. Denver, Colorado: Bureau of Reclamation and U.S. Geological Survey. ACC: MOL.19970625.0096.

170284 ASM (American Society of Metals) 1961. "Properties and Selection of Metals." Volume 1 of Metals Handbook. 8th Edition. Lyman, T.; ed. Metals Park, Ohio: American Society for Metals. TIC: 257281.

101992 ASM International. 1987. Corrosion. Volume 13 of ASM Handbook. 9th Edition. Materials Park, Ohio: ASM International. TIC: 240704.

171953 Beason, S. 2003. Collection of Underground Site Characterization Data. Scientific Notebook SN-USGS-SCI-084-V1 [final submittal]. Pages 1-155

ACC: MOL.20040112.0121.

103524 Bird, R.B.; Stewart, W.E.; and Lightfoot, E.N. 1960. Transport Phenomena. New York, New York: John Wiley \& Sons. TIC: 208957.

129637 Blair, S.C.; Kelly, J.M.; Pine, O.; Pletcher, R.; and Berge, P.A. 1996. Effect of Radiation on the Mechanical Properties of Topopah Spring Tuff. UCRL-ID-122899. Livermore, California: Lawrence Livermore National Laboratory. ACC: MOL.19961021.0132.

171508 BSC (Bechtel SAIC Company) 2001. Performance Assessment of a Potential Post-Closure Pyrophoric Event Involving Uranium Metal Spent Fuel. CAL-WIS-PA-000009 REV 00. Las Vegas, Nevada: Bechtel SAIC Company. ACC: MOL.20011213.0237.

156807 BSC 2001. Plugging of Stress Corrosion Cracks by Precipitates. CAL-EBS-MD-000017 REV 00. Las Vegas, Nevada: Bechtel SAIC Company. ACC: MOL.20011010.0168.

154004 BSC 2001. Waste Package Barrier Stresses Due to Thermal Expansion. CAL-EBS-ME-000008 REV 00. Las Vegas, Nevada: Bechtel SAIC Company. ACC: MOL.20011211.0149.

152655 BSC 2001. Waste Package Outer Barrier Stress Due to Thermal Expansion with Various Barrier Gap Sizes. CAL-EBS-ME-000011 REV 00. Las Vegas, Nevada: Bechtel SAIC Company. ACC: MOL.20011212.0222. 
164562 BSC 2003. Radiological Releases Due to Air and Silica Dust Activation in Emplacement Drifts. 800-00C-EBS0-00100-000-00A. Las Vegas, Nevada: Bechtel SAIC Company. ACC: ENG.20030509.0001.

165315 BSC 2003. Subsurface Facilities Overall Layout. 800-P00-MGR0-00210-000-00A. Las Vegas, Nevada: Bechtel SAIC Company. ACC: ENG.20030811.0010.

170710 BSC 2004. 21-PWR Waste Package Configuration. 000-MW0-DSU0-00403-00000D. Las Vegas, Nevada: Bechtel SAIC Company. ACC: ENG.20040708.0005.

169131 BSC 2004. Abstraction of Drift Seepage. MDL-NBS-HS-000019 REV 01. Las Vegas, Nevada: Bechtel SAIC Company. ACC: DOC.20041103.0003.

169617 BSC 2004. Abstraction of Drift-Scale Coupled Processes. MDL-NBS-HS-000018 REV 00 Errata 002. Las Vegas, Nevada: Bechtel SAIC Company. ACC: DOC.20031223.0004; DOC.20040223.0003; DOC.20040512.0001.

171924 BSC 2004. Aging and Phase Stability of Waste Package Outer Barrier. ANL-EBS-MD-000002 REV 02. Las Vegas, Nevada: Bechtel SAIC Company. ACC: DOC.20041005.0003.

170024 BSC 2004. Analysis of Mechanisms for Early Waste Package/Drip Shield Failure. CAL-EBS-MD-000030 REV 00C. Las Vegas, Nevada: Bechtel SAIC Company. ACC: DOC.20040913.0006; DOC.20050606.0005.

169982 BSC 2004. Aqueous Corrosion Rates for Waste Package Materials. ANL-DSD-MD-000001 REV 01. Las Vegas, Nevada: Bechtel SAIC Company. ACC: DOC.20041012.0003.

168030 BSC 2004. Characterize Framework for Seismicity and Structural Deformation at Yucca Mountain, Nevada. ANL-CRW-GS-000003 REV 00 Errata 001. Las Vegas, Nevada: Bechtel SAIC Company. ACC: MOL.20000510.0175; DOC.20040223.0007.

170019 BSC 2004. Clad Degradation - FEPs Screening Arguments. ANL-WIS-MD-000008 REV 02. Las Vegas, Nevada: Bechtel SAIC Company. ACC: DOC.20041020.0014.

169766 BSC 2004. Commercial SNF Waste Package Design Report. 000-00C-DSU0-02800000-00B. Las Vegas, Nevada: Bechtel SAIC Company. ACC: ENG.20040709.0001.

168489 BSC 2004. D\&E / PA/C IED Emplacement Drift Configuration and Environment. 800-IED-MGR0-00201-000-00B. Las Vegas, Nevada: Bechtel SAIC Company. ACC: ENG.20040326.0001.

168370 BSC 2004. D\&E / PA/C IED Subsurface Facilities. 800-IED-WIS0-00103-000-00A. Las Vegas, Nevada: Bechtel SAIC Company. ACC: ENG.20040309.0028. 
172801 BSC 2004. D\&E/RIT IED Subsurface Facilities [Sheet 1 of 4]. 800-IED-WIS0-00101-000-00B. Las Vegas, Nevada: Bechtel SAIC Company. ACC: ENG.20041130.0002.

168067 BSC 2004. Design and Engineering, Interlocking Drip Shield Configuration. 000-M00-SSE0-00102-000-00B. Las Vegas, Nevada: Bechtel SAIC Company. ACC: ENG.20040305.0021.

170027 BSC 2004. Development of Earthquake Ground Motion Input for Preclosure Seismic Design and Postclosure Performance Assessment of a Geologic Repository at Yucca Mountain, NV. MDL-MGR-GS-000003 REV 01. Las Vegas, Nevada: Bechtel SAIC Company. ACC: DOC.20041111.0006.

169855 BSC 2004. Development of Numerical Grids for UZ Flow and Transport Modeling. ANL-NBS-HS-000015 REV 02. Las Vegas, Nevada: Bechtel SAIC Company. ACC: DOC.20040901.0001.

172227 BSC 2004. Dose Rate Calculation for 21-PWR Waste Package. 000-00C-DSU0-01800-000-00C. Las Vegas, Nevada: Bechtel SAIC Company. ACC: ENG.20041102.0003.

166107 BSC 2004. Drift Degradation Analysis. ANL-EBS-MD-000027 REV 03. Las Vegas, Nevada: Bechtel SAIC Company. ACC: DOC.20040915.0010; DOC.20050419.0001.

170040 BSC 2004. Drift-Scale Radionuclide Transport. MDL-NBS-HS-000016 REV 01. Las Vegas, Nevada: Bechtel SAIC Company. ACC: DOC.20040927.0031.

166879 BSC 2004. Drip Shield and Waste Package Emplacement Pallet Design Report. 000-00C-SSE0-00100-000-00A. Las Vegas, Nevada: Bechtel SAIC Company. ACC: ENG.20040225.0016.

168993 BSC 2004. Drip Shield Structural Response to Rock Fall. 000-00C-SSE0-00300000-00A. Las Vegas, Nevada: Bechtel SAIC Company. ACC: ENG.20040405.0019.

172453 BSC 2004. DSNF and Other Waste Form Degradation Abstraction. ANL-WIS-MD-000004 REV 04. Las Vegas, Nevada: Bechtel SAIC Company. ACC: DOC.20041201.0007.

168138 BSC 2004. Estimation of Mechanical Properties of Crushed Tuff for Use as Ballast Material in Emplacement Drifts. 800-CYC-SSE0-00100-000-00A. Las Vegas, Nevada: Bechtel SAIC Company. ACC: ENG.20040309.0023.

168889 BSC 2004. Evaluation of Emplacement Drift Stability for KTI Resolutions. 800-KMC-SSE0-00200-000-00A. Las Vegas, Nevada: Bechtel SAIC Company. ACC: ENG.20040520.0001. 
169991 BSC 2004. Evaluation of Potential Impacts of Microbial Activities on Drift Chemistry. ANL-EBS-MD-000038 REV 01. Las Vegas, Nevada: Bechtel SAIC Company. ACC: DOC.20041118.0005.

169845 BSC 2004. General Corrosion and Localized Corrosion of the Drip Shield. ANL-EBS-MD-000004 REV 02. Las Vegas, Nevada: Bechtel SAIC Company. ACC: DOC.20040921.0002.

169984 BSC 2004. General Corrosion and Localized Corrosion of Waste Package Outer Barrier. ANL-EBS-MD-000003 REV 02. Las Vegas, Nevada: Bechtel SAIC Company. ACC: DOC.20041004.0001.

164327 BSC 2004. In-Drift Natural Convection and Condensation. MDL-EBS-MD-000001 REV 00. Las Vegas, Nevada: Bechtel SAIC Company. ACC: DOC.20041025.0006; DOC.20050330.0001.

169863 BSC 2004. In-Drift Precipitates/Salts Model. ANL-EBS-MD-000045 REV 02. Las Vegas, Nevada: Bechtel SAIC Company. ACC: DOC.20041111.0002.

171756 BSC 2004. Multiple Rock Fall on Drip Shield. 000-00C-SSE0-00200-000-00A. Las Vegas, Nevada: Bechtel SAIC Company. ACC: ENG.20040407.0009.

169858 BSC 2004. Post-Processing Analysis for THC Seepage. ANL-NBS-HS-000045 REV 00. Las Vegas, Nevada: Bechtel SAIC Company. ACC: DOC.20040929.0002; DOC.20050606.0006.

169885 BSC 2004. Postclosure Modeling and Analyses Design Parameters. TDR-MGR-MD-000037 REV 00. Las Vegas, Nevada: Bechtel SAIC Company. ACC: DOC.20041109.0002.

171424 BSC 2004. Repository Subsurface Emplacement Drift Panel 2 General Arrangement. 800-KM0-SSE0-00901-000-00A. Las Vegas, Nevada: Bechtel SAIC Company. ACC: ENG.20040213.0001.

169776 BSC 2004. Repository Subsurface Emplacement Drifts Steel Invert Structure Sect. \& Committed Materials. 800-SS0-SSE0-00102-000-00B. Las Vegas, Nevada: Bechtel SAIC Company. ACC: ENG.20040520.0005.

167736 BSC 2004. Repository Subsurface Turnout Drift 1-8 Interface. 800-KM0-SSD0-00301-000-00A. Las Vegas, Nevada: Bechtel SAIC Company. ACC: ENG.20040220.0009.

167182 BSC 2004. Rock Fall on Waste Packages. 000-00C-MGR0-01400-000-00A. Las Vegas, Nevada: Bechtel SAIC Company. ACC: ENG.20040225.0012.

170037 BSC 2004. Saturated Zone Site-Scale Flow Model. MDL-NBS-HS-000011 REV 02. Las Vegas, Nevada: Bechtel SAIC Company. ACC: DOC.20041122.0001. 
167652 BSC 2004. Seepage Model for PA Including Drift Collapse. MDL-NBS-HS-000002 REV 03. Las Vegas, Nevada: Bechtel SAIC Company. ACC: DOC.20040922.0008.

172203 BSC 2004. Stress Corrosion Cracking of the Drip Shield, the Waste Package Outer Barrier, and the Stainless Steel Structural Material. ANL-EBS-MD-000005 REV 02. Las Vegas, Nevada: Bechtel SAIC Company. ACC: DOC.20041028.0008.

167083 BSC 2004. Structural Calculations of Waste Package Exposed to Vibratory Ground Motion. 000-00C-WIS0-01400-000-00A. Las Vegas, Nevada: Bechtel SAIC Company. ACC: ENG.20040217.0008.

170791 BSC 2004. Structural Stability of a Drip Shield Under Quasi-Static Pressure. 000-00C-SSE0-00500-000-00A. Las Vegas, Nevada: Bechtel SAIC Company. ACC: ENG.20040830.0032.

171334 BSC 2004. Technical Work Plan for: Near-Field Environment and Transport: Coupled Processes (Mountain-Scale TH/THC/THM, Drift-Scale THC Seepage, and Post-Processing Analysis for THC Seepage) Report Integration.

TWP-MGR-PA-000017 REV 01 ICN 01. Las Vegas, Nevada: Bechtel SAIC Company. ACC: DOC.20040816.0003.

169861 BSC 2004. UZ Flow Models and Submodels. MDL-NBS-HS-000006 REV 02. Las Vegas, Nevada: Bechtel SAIC Company. ACC: DOC.20041101.0004; DOC.20050629.0003.

169862 BSC 2004. Ventilation Model and Analysis Report. ANL-EBS-MD-000030 REV 04. Las Vegas, Nevada: Bechtel SAIC Company. ACC: DOC.20041025.0002.

174290 BSC 2005. Waste Form and In-Drift Colloids-Associated Radionuclide Concentrations: Abstraction and Summary. MDL-EBS-PA-000004 REV 02. Las Vegas, Nevada: Bechtel SAIC Company. ACC: DOC.20050823.0002.

170020 BSC 2004. Waste-Form Features, Events, and Processes. ANL-WIS-MD-000009 REV 02. Las Vegas, Nevada: Bechtel SAIC Company. ACC: DOC.20041028.0006.

175058 BSC 2005. Analysis of Dust Deliquescence for FEP Screening. ANL-EBS-MD-000074 REV 01. Las Vegas, Nevada: Bechtel SAIC Company.

174566 BSC 2005. Dissolved Concentration Limits of Radioactive Elements. ANL-WIS-MD-000010 REV 05. Las Vegas, Nevada: Bechtel SAIC Company. ACC: DOC.20050713.0006.

174225 BSC 2005. DOE and Commercial Waste Package System Description Document. 000-3YD-DS00-00100-000-006. Las Vegas, Nevada: Bechtel SAIC Company. ACC: ENG.20050620.0002. 
172232 BSC 2005. Drift-Scale Coupled Process (DST and TH Seepage) Models. MDL-NBS-HS-000015 REV 02. Las Vegas, Nevada: Bechtel SAIC Company. ACC: DOC.20050114.0004.

172862 BSC 2005. Drift-Scale THC Seepage Model. MDL-NBS-HS-000001 REV 04. Las Vegas, Nevada: Bechtel SAIC Company. ACC: DOC.20050218.0001.

174052 BSC 2005. Drip Shield Structural Response to Rock Fall Supplemental Calculation. 000-00C-SSE0-00700-000-00A. Las Vegas, Nevada: Bechtel SAIC Company. ACC: ENG.20050707.0002.

173433 BSC 2005. EBS Radionuclide Transport Abstraction. ANL-WIS-PA-000001 REV 02. Las Vegas, Nevada: Bechtel SAIC Company.

175083 BSC 2005. Engineered Barrier System: Physical and Chemical Environment. ANL-EBS-MD-000033 REV 05. Las Vegas, Nevada: Bechtel SAIC Company.

174190 BSC 2005. Features, Events, and Processes in SZ Flow and Transport. ANL-NBS-MD-000002 REV 04. Las Vegas, Nevada: Bechtel SAIC Company. ACC: DOC.20050822.0012.

174191 BSC 2005. Features, Events, and Processes in UZ Flow and Transport. ANL-NBS-MD-000001 REV 04. Las Vegas, Nevada: Bechtel SAIC Company. ACC: DOC.20050809.0002.

173981 BSC 2005. Features, Events, and Processes: Disruptive Events. ANL-WIS-MD-000005 REV 03. Las Vegas, Nevada: Bechtel SAIC Company.

173303 BSC 2005. IED Interlocking Drip Shield and Emplacement Pallet [Sheet 1 of 1]. 800-IED-WIS0-00401-000-00E. Las Vegas, Nevada: Bechtel SAIC Company. ACC: ENG.20050301.0007.

173871 BSC 2005. IED Subsurface Facilities Committed Materials [Sheet 1 of 1]. 800-IED-WIS0-01501-000-00A. Las Vegas, Nevada: Bechtel SAIC Company. ACC: ENG.20050406.0002.

173498 BSC 2005. IED Subsurface Facilities Ground Support Configuration [Sheet 1 of 1]. 800-IED-WIS0-01601-000-00A. Las Vegas, Nevada: Bechtel SAIC Company. ACC: ENG.20050406.0003.

173501 BSC 2005. IED Waste Package Configuration [Sheet 1 of 1]. 800-IED-WIS000601-000-00A. Las Vegas, Nevada: Bechtel SAIC Company. ACC: ENG.20050406.0005.

173705 BSC 2005. IED Waste Package Decay Heat Generation [Sheet 1 of 1]. 800-IEDWIS0-00701-000-00A. Las Vegas, Nevada: Bechtel SAIC Company. ACC: ENG.20050406.0006. 
173627 BSC 2005. IED Waste Package Processes, Ground Motion Time Histories, and Testing and Materials [Sheet 1 of 1]. 800-IED-WIS0-00501-000-00A. Las Vegas, Nevada: Bechtel SAIC Company. ACC: ENG.20050406.0004.

173426 BSC 2005. IED Waste Package Radiation Characteristics [Sheet 1 of 1]. 800-IEDWIS0-01301-000-00A. Las Vegas, Nevada: Bechtel SAIC Company.

ACC: ENG.20050406.0012.

174583 BSC 2005. In-Package Chemistry Abstraction. ANL-EBS-MD-000037 REV 04. Las Vegas, Nevada: Bechtel SAIC Company. ACC: DOC.20050714.0003.

173172 BSC 2005. Mechanical Assessment of the Waste Package Subject to Vibratory Ground Motion. CAL-WIS-AC-000001 REV 00B. Las Vegas, Nevada: Bechtel SAIC Company. ACC: DOC.20050823.0001.

173944 BSC 2005. Multiscale Thermohydrologic Model. ANL-EBS-MD-000049 REV 03. Las Vegas, Nevada: Bechtel SAIC Company. ACC: DOC.20050711.0001.

170137 BSC 2005. Peak Ground Velocities for Seismic Events at Yucca Mountain, Nevada. ANL-MGR-GS-000004 REV 00. Las Vegas, Nevada: Bechtel SAIC Company. ACC: DOC.20050223.0002.

174269 BSC 2005. Q-List. 000-30R-MGR0-00500-000-002. Las Vegas, Nevada: Bechtel SAIC Company. ACC: ENG.20050805.0006.

174836 BSC 2005. Safety Classification of SSCs and Barriers. 000-00C-MGR0-03000-000 REV 00A. Las Vegas, Nevada: Bechtel SAIC Company. ACC: ENG.20050805.0004.

173869 BSC 2005. Screening Analysis of Criticality Features, Events, and Processes for License Application. ANL-MGR-NU-000002 REV 00. Las Vegas, Nevada: Bechtel SAIC Company.

174995 BSC 2005. Screening of Features, Events, and Processes in Drip Shield and Waste Package Degradation. ANL-EBS-PA-000002 REV 05. Las Vegas, Nevada: Bechtel SAIC Company. ACC: DOC.20050817.0003.

173247 BSC 2005. Seismic Consequence Abstraction. MDL-WIS-PA-000003 REV 02. Las Vegas, Nevada: Bechtel SAIC Company.

174514 BSC 2005. Subsurface Facility Description Document. 800-3YD-SS00-00100-000002. Las Vegas, Nevada: Bechtel SAIC Company. ACC: ENG.20050714.0015.

174640 BSC 2005. Technical Management Review Board (TMRB) Decision Proposal. TMRB-2005-044. Las Vegas, Nevada: Bechtel SAIC Company. ACC: MOL.20050720.0247. 
174965 BSC 2005. Technical Management Review Board (TMRB) Decision Proposal. TMRB-2005-047. Las Vegas, Nevada: Bechtel SAIC Company. ACC: MOL.20050809.0101.

174990 BSC 2005. Technical Management Review Board (TMRB) Decision Proposal. TMRB-2005-050. Las Vegas, Nevada: Bechtel SAIC Company. ACC: MOL.20050817.0253.

173694 BSC 2005. Technical Work Plan for: Revision to EBS FEPs Document. TWP-MGR-PO-000004 REV 00. Las Vegas, Nevada: Bechtel SAIC Company. ACC: DOC.20050518.0001.

173800 BSC 2005. The Development of the Total System Performance Assessment-License Application Features, Events, and Processes. TDR-WIS-MD-000003 REV 02. Las Vegas, Nevada: Bechtel SAIC Company.

166275 Canori, G.F. and Leitner, M.M. 2003. Project Requirements Document. TER-MGRMD-000001 REV 02. Las Vegas, Nevada: Bechtel SAIC Company.

ACC: DOC.20031222.0006.

162387 Christensen, H. and Sunder, S. 2000. "Current State of Knowledge of Water Radiolysis Effects on Spent Nuclear Fuel Corrosion." Nuclear Technology, 131, (1), 102-123. La Grange Park, Illinois: American Nuclear Society. TIC: 254040.

171411 Craig, R.W. 2001. "Transmittal of Level 5 Deliverable SPW205M5, 'ExcavationInduced Fracture Study'." Letter from R.W. Craig (USGS) to T.C. Gunter (DOE/YMSCO), September 26, 2001, with enclosure. ACC: MOL.20011114.0003.

151659 CRWMS (Civilian Radioactive Waste Management Service) M\&O (Management and Operating Contractor) 2000. Initial Cladding Condition. ANL-EBS-MD-000048 REV 00 ICN 01. Las Vegas, Nevada: CRWMS M\&O. ACC: MOL.20001002.0145.

149626 CRWMS M\&O 2000. Water Pooling-Evaporation in a Waste Package. CAL-EBS-NU-000009 REV 00. Las Vegas, Nevada: CRWMS M\&O. ACC: MOL.20000424.0698.

152016 CRWMS M\&O 2001. Water Distribution and Removal Model. ANL-EBS-MD000032 REV 01. Las Vegas, Nevada: CRWMS M\&O. ACC: MOL.20010214.0031.

170557 Curry, P.M. 2004. Project Functional and Operational Requirements. TDR-MGR-ME-000003 REV 02. Las Vegas, Nevada: Bechtel SAIC Company. ACC: DOC.20040714.0003.

100722 Dean, J.A. 1992. Lange's Handbook of Chemistry. 14th Edition. New York, New York: McGraw-Hill. TIC: 240690. 
122980 DOE (U.S. Department of Energy) 1998. Update to Assessment of Direct Disposal in Unsaturated Tuff of Spent Nuclear Fuel and High-Level Waste Owned by U.S. Department of Energy. DOE/SNF/REP-015. Washington, D.C.: U.S. Department of Energy. TIC: 243859.

155970 DOE (U.S. Department of Energy) 2002. Final Environmental Impact Statement for a Geologic Repository for the Disposal of Spent Nuclear Fuel and High-Level Radioactive Waste at Yucca Mountain, Nye County, Nevada. DOE/EIS-0250. Washington, D.C.: U.S. Department of Energy, Office of Civilian Radioactive Waste Management. ACC: MOL.20020524.0314; MOL.20020524.0315; MOL.20020524.0316; MOL.20020524.0317; MOL.20020524.0318; MOL.20020524.0319; MOL.20020524.0320.

171539 DOE 2004. Quality Assurance Requirements and Description. DOE/RW-0333P, Rev. 16. Washington, D.C.: U.S. Department of Energy, Office of Civilian Radioactive Waste Management. ACC: DOC.20040907.0002.

157677 Eatman, G.L.W.; Singleton, W.L.; Moyer, T.C.; Barr, D.L.; Albin, A.L.; Lung, R.C.; and Beason, S.C. 1997. Geology of the South Ramp - Station 55+00 to 78+77, Exploratory Studies Facility, Yucca Mountain Project, Yucca Mountain, Nevada. Denver, Colorado: U.S. Department of Energy. ACC: MOL.19980127.0396.

164789 Etherington, H., ed. 1958. Nuclear Engineering Handbook. 1st Edition. New York, New York: McGraw-Hill. TIC: 231758.

169321 Fix, D.V.; Estill, J.C.; Wong, L.L.; and Rebak, R.B. 2004. "Susceptibility of Welded and Non-Welded Titanium Alloys to Environmentally Assisted Cracking in Simulated Concentrated Ground Waters." Corrosion/2004, 59th Annual Conference \& Exposition, March 28-April 1, 2004, New Orleans. Paper No. 04551. Houston, Texas: NACE International. TIC: 255943.

109425 Forester, R.M.; Bradbury, J.P.; Carter, C.; Elvidge-Tuma, A.B.; Hemphill, M.L.; Lundstrom, S.C.; Mahan, S.A.; Marshall, B.D.; Neymark, L.A.; Paces, J.B.; Sharpe, S.E.; Whelan, J.F.; and Wigand, P.E. 1999. The Climatic and Hydrologic History of Southern Nevada During the Late Quaternary. Open-File Report 98-635. Denver, Colorado: U.S. Geological Survey. TIC: 245717.

100860 Gdowski, G.E. and Bullen, D.B. 1988. Oxidation and Corrosion. Volume 2 of Survey Of Degradation Modes of Candidate Materials for High-Level RadioactiveWaste Disposal Containers. UCID-21362. Livermore, California: Lawrence Livermore National Laboratory. ACC: MOL.19980715.0384.

105021 Glass, R.S.; Overturf, G.E.; Van Konynenburg, R.A.; and McCright, R.D. 1986. "Gamma Radiation Effects on Corrosion-I. Electrochemical Mechanisms for the Aqueous Corrosion Processes of Austenitic Stainless Steels Relevant to Nuclear Waste Disposal in Tuff." Corrosion Science, 26, (8), 577-590. Oxford, Great Britain: Pergamon. TIC: 226179. 
173726 Gordon, G. 2005. "Relevant Titanium Alloy Low Temperature Creep Properties." Interoffice memorandum from G. Gordon (BSC) to D. Stahl, April 26, 2005, 0426055388." ACC: MOL.20050504.0324.

170174 Green, R.T.; Evans, D.D.; and Filippone, W.L. 1987. "Effect of Electric Fields on Vapor Transport Near a High-Level Waste Canister." Chapter 32 of Coupled Processes Associated with Nuclear Waste Repositories. Tsang, C-F., ed. Orlando, Florida: Academic Press. TIC: 200325.

171800 Hirschfelder, J.O.; Curtiss, C.F.; and Bird, R.B 1964. Molecular Theory of Gases and Liquids. New York, New York: John Wiley \& Sons. TIC: 103052.

153282 Howard, C.L.; Finley, R.L.; Johnston, R.L.; Taylor, R.S.; George, J.T.; Lowry, W.E.; and Mason, N.G. 2001. Engineered Barrier System-Pilot Scale Test \#3, Heated Drip Shield Test Results. TDR-EBS-SE-000001 REV 00. Las Vegas, Nevada: Bechtel SAIC Company. ACC: MOL.20010529.0330.

134666 Keenan, J.H.; Keyes, F.G.; Hill, P.G.; and Moore, J.G. 1969. Steam Tables, Thermodynamic Properties of Water Including Vapor, Liquid, and Solid Phases (English Units). New York, New York: John Wiley \& Sons. TIC: 246766.

159337 Larrabee, C.P. 1953. “Corrosion Resistance of High-Strength Low-Alloy Steels as Influenced by Composition and Environment." Corrosion, 9, 259-271. Houston, Texas: National Association of Corrosion Engineers. TIC: 223386.

154380 Lee, S. and Staehle, R.W. 1994. Report to TRW on Contract No. DX 1456KP2L, Adsorption Studies of Water on Gold, Copper, Nickel and Iron Using the QuartzCrystal Microbalance Technique. Minneapolis, Minnesota: University of Minnesota. ACC: NNA.19940428.0129.

131202 Lide, D.R., ed. 1991. CRC Handbook of Chemistry and Physics. 72nd Edition. Boca Raton, Florida: CRC Press. TIC: 3595.

101719 Manaktala, H.K. 1993. Characteristics of Spent Nuclear Fuel and Cladding Relevant to High-Level Waste Source Term. CNWRA 93-006. San Antonio, Texas: Center for Nuclear Waste Regulatory Analyses. TIC: 208034.

100776 Manteufel, R.D.; Ahola, M.P.; Turner, D.R.; and Chowdhury, A.H. 1993. A Literature Review of Coupled Thermal-Hydrologic-Mechanical-Chemical Processes Pertinent to the Proposed High-Level Nuclear Waste Repository at Yucca Mountain. NUREG/CR-6021. Washington, D.C.: U.S. Nuclear Regulatory Commission. TIC: 207771. 
159336 McCright, R.D.; Halsey, W.G.; and Van Konynenburg, R.A. 1987. Progress Report on the Results of Testing Advanced Conceptual Design Metal Barrier Materials Under Relevant Environmental Conditions for a Tuff Repository. UCID-21044. Livermore, California: Lawrence Livermore National Laboratory. ACC: HQX.19880201.0016.

108218 McGraw, M.A. 1996. The Effect of Colloid Size, Colloid Hydrophobicity, and Volumetric Water Content on the Transport of Colloids Through Porous Media. Ph.D. dissertation. Berkeley, California: University of California. TIC: 245722.

163274 NRC (U.S. Nuclear Regulatory Commission) 2003. Yucca Mountain Review Plan, Final Report. NUREG-1804, Rev. 2. Washington, D.C.: U.S. Nuclear Regulatory Commission, Office of Nuclear Material Safety and Safeguards. TIC: 254568.

125806 Perry, R.H.; Green, D.W.; and Maloney, J.O., eds. 1984. Perry's Chemical Engineers' Handbook. 6th Edition. New York, New York: McGraw-Hill. TIC: 246473.

165318 Piron, J.P. and Pelletier, M. 2001. "State of the Art on the Helium Issues." Section 5.3 of Synthesis on the Long Term Behavior of the Spent Nuclear Fuel. Poinssot, C., ed. CEA-R-5958(E). Volume 1. Paris, France: Commissariat à l'Énergie Atomique. TIC: 253976.

156800 Plinski, M.J. 2001. Waste Package Operations Fabrication Process Report. TDREBS-ND-000003 REV 02. Las Vegas, Nevada: Bechtel SAIC Company. ACC: MOL.20011003.0025.

165537 Pulvirenti, A.L.; Needham, K.M.; Adel-Hadadi, M.A.; Marks, C.R.; Gorman, J.A.; and Barkatt, A. 2002. "Effects of Lead, Mercury, and Reduced Sulfur Species on the Corrosion of Alloy 22 in Concentrated Groundwaters as a Function of $\mathrm{pH}$ and Temperature." Scientific Basis for Nuclear Waste Management XXV, Symposium held November 26-29, 2001, Boston, Massachusetts. McGrail, B.P. and Cragnolino, G.A., eds. 713, 89-95. Warrendale, Pennsylvania: Materials Research Society. TIC: 248663.

102097 Rousseau, J.P.; Kwicklis, E.M.; and Gillies, D.C., eds. 1999. Hydrogeology of the Unsaturated Zone, North Ramp Area of the Exploratory Studies Facility, Yucca Mountain, Nevada. Water-Resources Investigations Report 98-4050. Denver, Colorado: U.S. Geological Survey. ACC: MOL.19990419.0335.

174054 Sargent G. and Conrad H. 1969. "Stress Relaxation and Thermally Activated Deformation in Titanium." Scripta Metallurgica, 3, (1), 43-50. New York, New York: Pergamon Press. TIC: 257403. 
100927 Southwell, C.R.; Bultman, J.D.; and Alexander, A.L. 1976. "Corrosion of Metals in Tropical Environments - Final Report of 16-Year Exposures." Materials Performance, 15, (7), 9-25. Houston, Texas: National Association of Corrosion Engineers. TIC: 224022.

125332 Stumm, W. and Morgan, J.J. 1996. Aquatic Chemistry, Chemical Equilibria and Rates in Natural Waters. 3rd Edition. New York, New York: John Wiley \& Sons. TIC: 246296.

164012 Tang, J.S. 2003. Technical Report of Calculations Supporting Evaluation of Radiation Effects. 000-30R-EBS0-00100-000-000. Las Vegas, Nevada: Bechtel SAIC Company. ACC: ENG.20030523.0002.

171801 Vidal, O. and Murphy, W.M. 1999. "Calculation of the Effect of Gaseous Thermodiffusion and Thermogravitation Processes on the Relative Humidity Surrounding a High Level Nuclear Waste Canister." Waste Management, 19, 189198. New York, New York: Pergamon. TIC: 256580.

114430 Wan, J. and Wilson, J.L. 1994. "Colloid Transport in Unsaturated Porous Media." Water Resources Research, 30, (4), 857-864. Washington, D.C.: American Geophysical Union. TIC: 222359.

111561 Weast, R.C., ed. 1985. CRC Handbook of Chemistry and Physics. 66th Edition. Boca Raton, Florida: CRC Press. TIC: 216054.

154918 Wu, Y-S.; Zhang, W.; Pan, L.; Hinds, J.; and Bodvarsson, G.S. 2000. Capillary Barriers in Unsaturated Fractured Rocks of Yucca Mountain, Nevada. LBNL-46876. Berkeley, California: Lawrence Berkeley National Laboratory. TIC: 249912.

\subsection{CODES, STANDARDS, REGULATIONS, AND PROCEDURES}

17327310 CFR 63. Energy: Disposal of High-Level Radioactive Wastes in a Geologic Repository at Yucca Mountain, Nevada. Readily available.

AP-2.22Q, Rev. 1, ICN 1. Classification Analyses And Maintenance Of The Q-List. Washington, D.C.: U.S. Department of Energy, Office of Civilian Radioactive Waste Management. ACC: DOC.20040714.0002.

LP-2.14Q-BSC, Rev. 0, ICN 0. Document Review. Washington, D.C.: U.S. Department of Energy, Office of Civilian Radioactive Waste Management. ACC: DOC.20050113.0007.

LP-3.15Q-BSC, Rev. 0, ICN 1. Managing Technical Product Inputs. Washington, D.C.: U.S. Department of Energy, Office of Civilian Radioactive Waste Management. ACC: DOC.20050622.0003. 
LP-SI.11Q-BSC, Rev. 0, ICN 1. Software Management. Washington, D.C.: U.S. Department of Energy, Office of Civilian Radioactive Waste Management. ACC: DOC.20041005.0008.

LP-SIII.2Q-BSC, Rev. 0, ICN 0. Qualification of Unqualified Data. Washington, D.C.: U.S. Department of Energy, Office of Civilian Radioactive Waste Management. ACC: DOC.20050119.0002.

LP-SIII.9Q-BSC, Rev. 0, ICN 1. Scientific Analyses. Washington, D.C.: U.S. Department of Energy, Office of Civilian Radioactive Waste Management. ACC: DOC.20050622.0004.

LP-SIII.10Q-BSC, Rev. 0, ICN 1. Models. Washington, D.C.: U.S. Department of Energy, Office of Civilian Radioactive Waste Management.

ACC: DOC.20050623.0001.

LP-SIII.11Q-BSC, Rev. 0, ICN 1. Scientific Notebooks. Washington, D.C.: U.S. Department of Energy, Office of Civilian Radioactive Waste Management. ACC: DOC.20050419.0002.

LP-SV.1Q-BSC, Rev. 0, ICN 0. Control of the Electronic Management of Information. Washington, D.C.: U.S. Department of Energy, Office of Civilian Radioactive Waste Management. ACC: DOC.20050531.0002.

YMP-USGS-GP-32, R2. Underground Geologic Mapping. Denver, Colorado: U.S. Geological Survey. ACC: MOL.19980930.0086.

\subsection{SOURCE DATA, LISTED BY DATA TRACKING NUMBER}

161976 LB0302DSCPTHCS.002. Drift-Scale Coupled Processes (THC Seepage) Model: Data Summary. Submittal date: 02/11/2003.

171706 LB0408CMATUZFT.004. Leaching of Altered Cementitious Materials - EQ3/6 Simulations for Cementitious Material Transport. Submittal date: 08/31/2004.

168769 LL040310323122.044. Input and Output Files of the MSTHM Micro-Abstractions for the Collapsed-Drift Cases for the TSPA-LA Low-Probability Seismic Scenario. Submittal date: 03/26/2004.

172097 MO0407SPAPCEML.005. EBS P\&CE Model Longevity of Materials Evaluation. Submittal date: 07/02/2004.

171483 MO0408MWDDDMIO.002. Drift Degradation Model Inputs and Outputs. Submittal date: $08 / 31 / 2004$.

172682 MO0501BPVELEMP.001. Bounded Horizontal Peak Ground Velocity Hazard at the Repository Waste Emplacement Level. Submittal date: 01/11/2005. 
172601 MO0501SEPFEPLA.001. LA FEP List and Screening. Submittal date: 01/17/2005.

174472 SN0506F4104405.003. Analyses of Phase I and Phase II Data from the Stress Corrosion Crack Flow Tests (Data from 1/12/2005 to 5/13/2005). Submittal date: 06/20/2005. 
APPENDIX A

QUALIFICATION OF DIRECT INPUTS LISTED IN TABLE 4-1 
Handbooks are considered to be compilations of established facts. However, handbooks in themselves derive or present no new information, they only present what has been published in open literature, either by textbook or publications. Thus when a textbook, source, or a publication is referenced (or cited) by a handbook, the textbook, source or publication becomes reliable because it is part of the handbook, which in its entirety is established fact. Therefore, some of the following sources are demonstrated to be reliable for the intended use identified in Table 4-1 because the reliability of these sources (per LP-SIII.9Q-BSC, Section 5.2.1 (1)) is demonstrated by being cited as references in the indicated handbooks and thus widely used in standard work practices by engineers and scientists. The other sources are demonstrated as being reliable by other specific methods as described by LP-SIII.9Q-BSC. The extent to which data (information or equations) demonstrate the properties (information or mathematics) of interest is also addressed.

Qualification of the use of information on Water Radiolysis Effects taken from Christensen, H. and Sunder, S. 2000 [DIRS 162387] — This data used to evaluate the potential for gamma radiation to generate oxygen- and hydrogen-bearing radicals comes from a peer reviewed journal, Nuclear Technology, published by the American Nuclear Society. The subject of the paper is specific to the topic of the effects of water radiolysis products on spent nuclear fuel oxidation and dissolution, which is appropriate for evaluating radiolysis of water in the EBS.

The authors are professionals in the technical fields of nuclear physics and are experts in this technical area. Hilbert Christensen, a senior scientist at Studsvik Material AB and an adjunct professor at the University of Linkoping, Sweden, has published extensively on the subject topic specifically relating to radiation chemistry of aqueous solutions. A related research field of his is radiolysis in connection with storage of high-level nuclear waste. S. Sunder is a scientist in the Fuel Safety Branch of the Atomic Energy of Canada Limited at Chalk River, Ontario, Canada. Previously, he did spectroscopic research at the National Research Council of Canada and taught at the University of Heidelburg, Germany. His technical field of expertise includes high temperature chemistry of nuclear fuel and fission products. He has published extensively and has received many awards and honors for his technical work.

Qualification of the use of information from Glass, R.S.; Overturf, G.E.; Van Konynenburg, R.A.; and McCright, R.D. 1986 [DIRS 105021] - The referenced source by Glass et al. was published in Corrosion Science, an accepted peer reviewed journal of corrosion properties and phenomena. Furthermore, a portion of this work was performed at Lawrence Livermore National Laboratory as part of the U.S. Department of Energy's Civilian Radioactive Waste Management Program as report number UCID-20174. Therefore, the information from the source by Glass et al. is reliable and qualified for the intended use because it has been in publication for approximately two decades, this source is produced from previous DOE work for containment of high-level nuclear waste in tuff, and thus is widely used in the standard work processes for corrosion behavior of stainless steel. The extent to which this source of information addresses radiation effects on corrosion of Austenitic stainless steel is considered adequate because this topic is well known, as documented here.

Qualification of the use of information from Green, R.T.; Evans, D.D.; and Filippone, W.L 1987 [DIRS 170174] - The referenced information from Green et al. on the effect of electric fields on vapor (species) transport near a high-level waste canister is based on information that 
can be corroborated from other sources. The basis for the mass flux of ions (due to radiolysis) in an electric field due to an electric field enveloping a high-level- waste canister is given by Green et al. as the product of the electric field and ion mobility. This mass flux relationship can also be seen in Bird et al. (1960 [DIRS 103524]), as the right term in equation 18.5-21. This right term in equation 18.5-21 is (also) seen to be the product of the electric field (written as $\mathrm{d} \phi / \mathrm{dz}$ ) and the mobility (written as $\mathrm{D} \varepsilon_{\mathrm{i}} / \kappa \mathrm{T}$ ). This is the same term as that used by Green et al. in equations 1 through 3 with different notation. Therefore, the information from Green et al. is considered reliable for its intended use because the basis of the results is corroborated by another source. The extent to which this source of information addresses the vapor transport near a high-level waste canister due to radiolysis and an (induced) electric field is considered adequate because this phenomenon is reasonably well known as corroborated here.

Qualification of the use of information on the Soret effect (thermal diffusion) from Bird, R.B.; Stewart, W.E.; and Lightfoot, E.N. 1960 [DIRS 103524] - The referenced source by Bird et al. was first published in 1960 and has been in publication ever since. This source is referenced by a handbook by Perry et al. (1984 [DIRS 125806]), in the general references for Section 3: Physical and Chemical Data, which discusses diffusion coefficients, as reference 14. Therefore, the information from the source by Bird et al. is reliable and qualified for the intended use because it has been in publication for over four decades. This source is referenced in a handbook in the subject area of diffusion, and thus is widely used in the standard work practices on this topic. The extent to which this source of information addresses the Soret effect for thermal diffusion is considered adequate because this topic is discussed in a well-known reference, as documented here.

Qualification of the use of information on the seepage chemistry in the case of a collapsed drift and radionuclide sorption taken from Abstraction of Drift-Scale Processes (BSC 2004 [DIRS 169617]) - This source was prepared by qualified Bechtel SAIC Company, LLC (BSC), or sub-contract personnel in accordance with the approved procedure AP-SIII.10Q, Models. It was cited by three other BSC reports and analyses. Qualified data was used in the preparation of the source. The output of analyses from this source are still valid as the software used is still controlled, the procedures used to generate the data were in accordance with the applicable YMP Quality Assurance Requirements Description (BSC 2004 [DIRS 171539]), and the personnel performing the work were qualified by YMP procedure. The document contains an analysis prepared specifically to predict the seepage water chemistry in emplacement drifts in YMP and an analysis to determine temperature effects on radionuclide sorption for YMP substrates. This document was recently superseded because it was changed from a model report to a scientific analysis by Technical Work Plan for: Near-Field Environment and Transport: Coupled Processes (Mountain-Scale TH/THC/THM, Drift-Scale THC Seepage, and Post-Processing Analysis for THC Seepage) Report Integration (BSC 2004 [DIRS 171334], Section 1.2.3). The superseding document is Post-Processing Analysis for THC Seepage (BSC 2004 [DIRS 169858]). The superseding document does not contain the evaluation of seepage water chemistry for the collapsed drift case, nor the effects of temperature on sorption, which is the information cited by the current report in Section 6.2.90.

Qualification of the use of information on colloid-facilitated transport of radionuclides taken from Wan, J. and Wilson, J.L. 1994 [DIRS 114430]) - This data used to evaluate the potential for air bubbles to influence colloidal transport of radionuclides comes from a peer 
reviewed journal, the Water Resources Research published by the American Geophysical Union. The subject of the paper is specific to the topic of colloid facilitated transport in unsaturated media, which is appropriate for evaluating transport in the EBS. The authors are professionals in the technical fields of transport. The authors are experts in this technical area. Jiamin Wan, a staff scientist at Lawrence Berkeley Laboratory, has published extensively on the subject topic specifically relating to the importance of gas-water interfaces, and holds many professional awards. John Wilson is a professor of hydrology at the Department of Earth \& Environmental Science at New Mexico Tech, Socorro, New Mexico. His technical field of expertise includes fluid flow and transport in various media including transport via colloids. He has published extensively and has received many awards and honors for his technical work.

Qualification of the use of information on Exothermic Reactions taken from Assessment of a Potential Post-Closure Pyrophoric Event Involving Uranium Metal Spent Performance Fuel (BSC 2001 [DIRS 171508]) - The report was cancelled because the results were developed in support of Total System Performance Assessment for Site Recommendation rather than TSPA-LA. Qualified BSC or sub-contract personnel prepared this document in accordance with the approved procedure AP-SIII.10Q . It is currently cited by one other BSC report. Qualified data was used in the preparation of the document. The output of analyses from this source are still valid as the software used is still controlled, the procedures used to generate the data were in accordance with the applicable YMP Quality Assurance Requirements Description (BSC 2004 [DIRS 171539]), and the personnel performing the work were qualified by YMP procedure. The document contains an analysis prepared specifically to predict the amount of pyrophoric (exothermic) heat generated by uranium metal in waste packages for YMP.

The calculation of interest evaluates the consequences of a postclosure pyrophoric event in terms of its potential energy. The energy release from the oxidation of uranium metal in a waste package containing two multicanister overpacks was found to be $5.29 \times 107 \mathrm{~kJ} /$ package. The results of the calculations are still valid for use in the screening argument for FEP 2.1.11.03.0A (Exothermic Reactions in EBS).

Qualification of the use of information from Stumm, W; and Morgan, J.J. 1996 [DIRS 125332] - The referenced information used from Stumm and Morgan is the $\mathrm{pH}$ of "pristine" rainwater as 5.65 (1996 [DIRS 125332], Section 4.3: Aqueous Carbonate System Open in the Atmosphere, example 4.2 on page 161). This particular text (problems are given at the end of each chapter) is in its Third Edition. Thus this source of information is considered reliable because it has been in print for over 15 years (because there is a First Edition). Also, the information on the $\mathrm{pH}$ of rainwater is corroborated by Lide (1991 [DIRS 131202], from the table entitled: The $\mathrm{pH}$ of Natural Media and Its Relation to the Precipitation of Hydroxides, on page 14-10), where the $\mathrm{pH}$ of rainwater is given as a range of 5 to 6 . Therefore, the information from the source by Stumm and Morgan is reliable and qualified for the intended use because the reference has been in print for over 15 years and the information is corroborated by another source which is a handbook. The extent to which this source of information, Stumm and Morgan, addresses the data for the $\mathrm{pH}$ of rainwater is considered adequate because this information is well known as documented here. 
Qualification of information related to stress corrosion cracks and water diversion capacity in drip shields taken from Water Distribution and Removal Model (CRWMS M\&O 2001 [DIRS 152016]) - This source was prepared by qualified YMP or sub-contract personnel in accordance with the procedure AP-3.10Q, Analyses and Models, in effect at the time of document preparation. The output of analyses from this source is still valid as the procedures used to generate the data were in accordance with the applicable YMP Quality Assurance Requirements Description, and the personnel performing the work were qualified by YMP procedure. The document contains an analysis prepared specifically to predict the seepage potential through saturated SCCs in a drip shield in emplacement drifts in YMP - the same topic being addressed in the current report.

Qualification of the use of information on stress relaxation and deformation of titanium taken from G. Sargent and H. Conrad [DIRS 174054]) — This data used to evaluate the potential for titanium to stress relief with time after it has been loaded to stresses below and above the yield stress comes from a peer reviewed journal. This is the journal entitled "Scripta Metallurgica" and published by Pergamon Press. The authors were from the University of Kentucky at Lexington. One of the authors, Hans Conrad, is a Professor Emeritus at North Carolina State University, received his B. S. in Metallurgical Engineering from Carnegie Institute of Technology in 1943 and his Master of Engineering and Doctor of Engineering degrees in Metallurgy from Yale University in 1951 and 1955, respectively. He has been associated with a number of industrial and research organizations including Aerospace Corporation, Atomics International, Westinghouse Research Laboratories, Chase Brass and Copper Company, and The Aluminum Company of America (1943-45). This article is deemed appropriate for this citation based on the merits of this author and the University of Kentucky. This data was generated from titanium, the material of which the drip shield will be constructed. It was generated using a testing method applicable to the stress and strain load histories for drip shields damaged by rockfall, that is, a deformation is applied and the position is held static while stresses adjust with time.

Qualification of the use of information on episodic infiltration and percolation from Capillary Barriers in Unsaturated Fractured Rocks of Yucca Mountain, Nevada (Wu et al. 2000 [DIRS 154918]) - This information is used to show that the hydrologic effect of episodic infiltration is temporally damped after passing through the PTn. This results in relatively steady flow at the repository horizon and below to the water table. This behavior is used to justify a steady-state UZ flow model that uses temporally averaged infiltration maps as the upper boundary condition. The property of interest is the effect of transient infiltration on flow. Episodic infiltration pulses with rates exceeding $25,000 \mathrm{~mm} / \mathrm{yr}$ for a one week duration occurring every 50 years are evaluated (Wu et al. (2000 [DIRS 154918], Section 4.1 and Figure 4.1-11). The resulting flow from the PTn is shown to have fluctuations of less than $1 \mathrm{~mm} / \mathrm{yr}$. The software used for the simulations was TOUGH2, a code that is used extensively on the Yucca Mountain Project. The author, Yu-Shu Wu, has a B.S. in Reservoir Engineering from Daqing Petroleum Institute, China; an M.S. in Flow in Porous Media from Southwest Petroleum Institute, China; and a Ph.D. in Reservoir Engineering/Hydrogeology from the University of California at Berkeley. He has contributed to the Yucca Mountain Project since 1995 as a Staff Geological Scientist. 
Qualification of the use of information from Hirschfelder, J.O.; Curtis, C.F.; and Bird, R.B. 1964 [DIRS 171800] - The referenced source by Hirschfelder et al., Molecular Theory of Gases and Liquids, was originally published in 1954, and is regarded as a first source of fundamental physical phenomena from a "molecular" viewpoint. This source has its origins as an outgrowth of a National Defense Research Committee Report (A-116), entitled "The Thermodynamic Properties of Propellant Gases," written in 1942 by J.O. Hirschfelder, F.T. McClure, C.F. Curtis, and D.W. Osborne. Thus the qualifications of the authors J.O. Hirschfelder and C.F. Curtis are considered excellent because of their authorship of these references, and Molecular Theory of Gases and Liquids is still used by scientist and engineers. R.B. Bird is also the one of the authors of Transport Phenomena (Bird et al. 1960 [DIRS 103524]). This is also a source of fundamental physical phenomena from a "molecular" viewpoint, and is still used by scientist and engineers. Thus, the qualifications of these three authors are considered excellent and the resulting information, specifically the magnitude of the Soret effect for thermal diffusion, is considered adequate because this topic is discussed by these three authors in the noted reference, as discussed here. 


\section{INTENTIONALLY LEFT BLANK}




\section{APPENDIX B}

QUALIFICATION OF DATA FROM CRAIG (2001 [DIRS 171411]) 
A study by Craig (2001 [DIRS 171411]) was submitted in 2001 as a Level 5 deliverable to the Yucca Mountain Project. The report presents observations regarding excavation-induced fractures in the ESF and the ECRB Cross-Drift, and compares excavations using tunnel-boring machines, alpine miner, and drill and blast techniques. The observations were originally recorded in Scientific Notebooks, and supplemented the geologic mapping fracture frequency data that were subsequently submitted to the Technical Data Management System as qualified data. The data of specific interest in the study by Craig (2001 [DIRS 171411]) are the relative destructiveness of the techniques, the character and extent of the mechanical damage, impact on tunnel cross section, and depth of the excavation-induced damage. The data are shown below to be qualified for the intended use in this Analysis Report (Section 6.2.2). This qualification is in accordance with LP-SIII.2Q-BSC, Qualification of Unqualified Data, and the Data Qualification Plan included in Section B.5, below.

\section{B.1 QUALIFICATION TEAM}

Qualification Chairperson is Florie Caporuscio.

The second member of the team is Dwayne Kicker, who is technically competent and an expert in the area of rock mechanics. He is originator of Drift Degradation Analysis (BSC 2004 [DIRS 166107]).

The members of the qualification team are independent of the data set to be qualified.

\section{B.2 METHOD OF QUALIFICATION}

The data are qualified using the Technical Assessment approach (LP-SIII.2Q-BSC, Attachment 3):

- Data Collection Methodology Is Acceptable. The data collection method consists of recording visual observations made by the mapping geologists in a scientific notebook, which in turn is technically reviewed. This method is typical of geologic investigations; it is perscribed through the procedure that governed the underground mapping, U.S. Geological Survey Procedure YMP-USGS-GP-32, Underground Geologic Mapping.

- Confidence in the Data Acquistion or Developmental Results Is Warranted.

- Data Acquisition Method Is Appropriate: The underground excavation observations were made and recorded in a scientific notebook (Beason 2003 [DIRS 171953], pp. 77 to 80), using a YMP Scientific Notebook procedure (AP-SIII.1Q, Scientific Notebooks) that was developed to address the quality assurance requirements of the YMP Quality Assurance Requirements Description (BSC 2004 [DIRS 171539], Supplement III), and, by extension, the requirements of 10 CFR 60, Subpart G [DIRS 173273]. A scientific notebook procedure has been used on the YMP since 1996. The Beason notebook (2003 [DIRS 171953], p. 81) documents the scientific observations, the person who entered the data in the notebook and the technical review of the notebook entry.

- Data Was Collected by Qualified Individuals: The excavation-induced fracture study was conducted by members of the US Bureau of Reclamation geology mapping group. 
The U.S. Bureau of Reclamation is one of the government agencies responsible for geologic mapping of federal projects, particularly dam sites and tunnels. The YMP geologists from the U.S. Bureau of Reclamation mapped approximately $10 \mathrm{~km}$ of underground tunnels at Yucca Mountain, including the ESF and the Enhanced Characterization of the Repository Block (ECRB) Cross-Drift, between 1994 and 1997. The team subsequently compiled their findings in completion reports for the various excavations (i.e., Albin et al 1997 [DIRS 101367], Eatman et al. 1997 [DIRS 157677]).

- The Data Were Collected under Proper Environmental Conditions: The observations that served as the basis for the Craig (2001[DIRS 171411]) reference were made after the tunnel walls were cleaned of tunneling muck, allowing observations of geologic details. The cleaning of the tunnel walls was required for the geologic mapping of the tunnel.

- The Resulting Observations Are Appropriate for Their Intended Use: The data were collected to compare the relative excavation effects of different mining techniques, including use of the tunnel-boring machine, alpine miner, and drill and blast techniques. The current report compares the relative destructiveness of the various mining techniques, and specifically uses the observations derived from the tunnel-boring maching excavations. The observations directly relate to concerns regarding ability to maintain the circular cross-section of a tunnel-boring maching tunnel, and depth of damage, and significance of the damage to modelling studies.

- Data Have Been Used in Similar Applications. The underground tunnel data collected by the U.S. Bureau of Reclamation mapping team has been used extensively for YMP performance assessment and facility layout. The geologic and fracture data provide input into the hydrologic models for the unsaturated zone, and the information obtained regarding the mechanical stability of the rock has been used to determine the extent and orientation of the underground facilities.

\section{B.3 EVALUATION CRITERIA}

The data from Craig (2001 [DIRS 171411]) used in the current report will be considered qualified if the data can be traced back to the original source, and if the relevant conclusions and observations reported by Craig (2001 [DIRS 171411]) can be independently corroborated by the independent subject matter expert.

\section{B.4 EVALUATION RESULTS}

The scientific notebook pages that support the Excavation-Induced Fracture Study (Beason 2003 [DIRS 171953], pp. 77 to 80) were reviewed by the subject matter expert of the data qualification team. The data from Craig (2001 [DIRS 171411]) used in the current report were found to be recorded in the Scientific Notebook. Therefore, the data used from Craig (2001 [DIRS 171411]) is qualified for use in the current report. There are no limits or caveats on the use of these data. 


\section{B.5 DATA QUALIFICATION PLAN}

A facsimile of the data qualification plan developed for the above qualification effort is provided below. The original is included in the records package for this analysis report.

\begin{tabular}{|l|l|l|}
\hline \multirow{2}{*}{ BSC } & Data Qualification PLaN & QA: QA \\
\cline { 3 - 3 } & Page 1 of 1 \\
\hline
\end{tabular}

\begin{tabular}{|c|c|c|}
\hline \multicolumn{3}{|l|}{$\begin{array}{l}\text { Qualification Title } \\
\text { Qualification of } \\
\text { PA-000002 }\end{array}$} \\
\hline \multicolumn{3}{|c|}{$\begin{array}{l}\text { Requesting Organization } \\
\text { Regulatory Integration Team / Near-Field Environment and Transport }\end{array}$} \\
\hline \multicolumn{3}{|c|}{ Section II. Process Planning Requirements } \\
\hline \multicolumn{3}{|c|}{$\begin{array}{l}\text { Observations and conclusions regarding the character and extent excavation-induced damage to rock mass by tunnel boring machines. } \\
\text { The data used in ANL-WIS-PA-000002 include roughess of tunnel resulting from TBM mining, depth of influence on the rock walls } \\
\text { of the tunnel, as reported in: Craig, R.W. 2001. "Transmittal of Level } 5 \text { Deliverable SPW205M5, 'Excavation-Induced Fracture } \\
\text { Study'." Letter from R.W. Craig (USGS) to T.C. Gunter (DOE/YMSCO), September 26, 2001, with enclosure. ACC: } \\
\text { MOL.20011114.0003. [DIRS 171411]. }\end{array}$} \\
\hline \multicolumn{3}{|c|}{$\begin{array}{l}\text { Technical Assessment (Method } 5 \text { in Attachment } 3 \text { of AP-SIII.2Q, REV 1, ICN 2) by a subject matter expert will conduct an } \\
\text { independent evaluation of the original data recorded in scientific notebooks to assess if the conclusions in the above paper can be } \\
\text { independently derived without recourse to the data originator. The evaluation will examine the methodology employed to record the } \\
\text { field observations, the qualification of the data collectors, and that data has been used in similar applications. Qualificatioin } \\
\text { Attributes to be used (from Attachment } 4 \text { of SIII.2Q REV 1, ICN 1) include: (1) Qualification of personnel and organizations } \\
\text { generating the data, (2) The technical adequacy of procedures used to collect and analyze the data, (3) The extent to which the data } \\
\text { demonstrate the properties of interest, and (9) Extent and reliability of the documentation associated with the data. }\end{array}$} \\
\hline \multicolumn{3}{|c|}{$\begin{array}{l}\text { 3. Data Qualification Team and Additional Support Staff Required } \\
\text { Florie Caporuscio, Chairperson } \\
\text { Dwayne Kicker, Additional Support Staff - Subject matter expert }\end{array}$} \\
\hline \multicolumn{3}{|c|}{$\begin{array}{l}\text { 4. Data Evaluation Criteria } \\
\text { The above report will be considered qualified if the data used in ANL-WIS-MD- } 000002 \text { can be traced back to the original source, and } \\
\text { if the relevant conclusions and observations reported in Craig } 2001 \text { can be independently corroborated by the independent subject } \\
\text { matter expert. }\end{array}$} \\
\hline \multicolumn{3}{|c|}{$\begin{array}{l}\text { 5. Identification of Procedures Used } \\
\text { AP-SIII.2Q, Qualification of Unqualified Data } \\
\text { AP-SIII.9Q, Scientific Analysis }\end{array}$} \\
\hline \multicolumn{3}{|l|}{ Section III. Approval } \\
\hline $\begin{array}{l}\text { Qualification Chairperson Printed Name } \\
\text { Florie Caporuscio }\end{array}$ & Qualificatign Chairperson Signatureg & ${ }^{\text {Date }} 10-8-09$ \\
\hline $\begin{array}{l}\text { Responsible Manager Printed Name } \\
\text { Ernest Hardin }\end{array}$ & Responjofe Manager Signature & Date $10 / 8 / 04$ \\
\hline
\end{tabular}




\section{INTENTIONALLY LEFT BLANK}




\section{APPENDIX C}

ANALYSIS OF ROCKFALL AND ITS IMPACT TO DRIP SHIELD DENTING AND CRACKING 


\section{C.1 INTRODUCTION}

This appendix provides an analysis of data on rockfalls capable of denting and cracking a drip shield. The results from this analysis support the screening argument for the advection of liquids and solids through cracks in the drip shield (Section 6.2.64).

The response of the rock mass surrounding a repository emplacement drift to a seismic event is a function of the structural characteristics of the rock. In the repository, lithophysal units (including the upper lithophysal zone [Tptpul] and lower lithophysal zone [Tptpll]) are characterized by lithophysal voids interconnected by intense fracturing as discussed in Drift Degradation Analysis (BSC 2004 [DIRS 166107], Section 6.4.1.1). The strength of the lithophysal rock ranges from approximately 10 to $40 \mathrm{MPa}$ (BSC 2004 [DIRS 166107], Table E-9). Postclosure ground motion in lithophysal rock results in rock failure, with fragmented rock particle sizes in the order of centimeters to decimeters (BSC 2004 [DIRS 166107], Section 8.1). The individual fragments are too small to damage the drip shield, as stated in Seismic Consequence Abstraction (BSC 2005 [DIRS 173247], Section 6.6.2). Approximately $85 \%$ of the repository emplacement area will be in lithophysal rocks (BSC 2004 [DIRS 168370], Table 8). Therefore, approximately $85 \%$ of the drip shields will not be subject to denting from rockfall.

The nonlithophysal units (including the middle nonlithophysal zone [Tptpmn] and the lower nonlithophysal zone [Tptpln]) are composed of strong, intact blocks of welded tuff that are separated by fracture planes (BSC 2004 [DIRS 166107], Section 6.4.1.1). The strength of the nonlithophysal rock ranges from approximately 60 to $300 \mathrm{MPa}$ (BSC 2004 [DIRS 166107], Table E-8). Postclosure ground motion in nonlithophysal rock results in a varying extent of drift damage due to rockfall (BSC 2004 [DIRS 166107], Section 8.1], with the rockfall results described in Drift Degradation Analysis (BSC 2004 [DIRS 166107], Section 6.3.1.2). Some of the rock blocks ejected from the walls or back of the emplacement drifts will impact the drip shield and could result in mechanically stressed areas. If the stress is sufficiently high, the damaged area will be susceptible to stress corrosion cracking as discussed in Stress Corrosion Cracking of the Drip Shield, the Waste Package Outer Barrier, and the Stainless Steel Structural Material (BSC 2004 [DIRS 172203], Section 6.2.1). This appendix provides a conservative estimate of the potential for damage (i.e., denting and cracking) to occur to the drip shield relative to its performance as a barrier to seepage contacting the waste packages. This analysis is designed to estimate the rockfall events that could result in such dents or cracking as a function of seismic event probabilities.

\section{C.2 PROBABILITY ANALYSIS FOR EBS FEP ARGUMENTS RELATED TO DRIP SHIELD DENTING}

The probability that seismic-induced rockfall causes a significant dent on the drip shield can be evaluated from structural response calculations for large rock blocks impacting the drip shield and from the bounded hazard curve for horizontal peak ground velocity (PGV) at the emplacement drifts. A dent is considered significant if it has a concave shape that can retain a significant amount of standing liquid (seepage) in the dent. 
The rockfall and denting probability analysis is based on three sources of information:

- Analysis of rockfall induced by vibratory ground motions in the nonlithophysal zones

- Structural response of the drip shield to individual rock block impacts

- The bounded hazard curve for PGV.

The occurrence of multiple rockfalls impacting the drip shield at the same location is addressed in Section 6.2.28 of the current report under FEP 2.1.07.01.0A. The probability analysis is conservative because of the issues discussed at the end of this section.

\section{C.2.1 Analysis of Rockfall Data in Nonlithophysal Zones}

Rockfall calculations for the nonlithophysal zones have been performed (BSC 2004 [DIRS 166107], Section 6.3) using vibratory ground motions at the $1.05 \mathrm{~m} / \mathrm{s}, 2.44 \mathrm{~m} / \mathrm{s}$, and $5.35 \mathrm{~m} / \mathrm{s}$ PGV levels, as presented in Development of Earthquake Ground Motion Input for Preclosure Seismic Design and Postclosure Performance Assessment of a Geologic Repository at Yucca Mountain, NV (BSC 2004 [DIRS 170027], Tables 6.3-14, 6.3-16, and 6.3-18). A total of 50 realizations were performed at the $1.05 \mathrm{~m} / \mathrm{s}$ and $2.44 \mathrm{~m} / \mathrm{s}$ PGV levels and 44 realizations were performed at the $5.35 \mathrm{~m} / \mathrm{s} \mathrm{PGV}$ level. Each realization analyzes the response of a 25-meter-long section of drift with a randomly sampled fracture pattern. The output from each realization includes the impact parameters (location, relative velocity, block kinetic energy, block momentum, etc.) of the individual rock blocks on the top and sides of the drip shield. The shape of the drip shield, depicted in Figure $\mathrm{C}-1$, in the rockfall calculations has been simplified to a rectangular cross-section as depicted in Figure C-2, ignoring the curvature of the top of the drip shield. This geometric simplification is not significant for the probability analysis that follows, since the simplified drip shield is only used as a marker for collecting rockfall data (i.e., locations and relative velocities of the rockfall impacts), as documented in Drift Degradation Analysis (BSC 2004 [DIRS 166107], Section 6.3.1.1).

The impact data for the rock blocks at the $1.05 \mathrm{~m} / \mathrm{s}, 2.44 \mathrm{~m} / \mathrm{s}$, and $5.35 \mathrm{~m} / \mathrm{s}$ PGV levels have been filtered to retain only the blocks that contact the top of the drip shield, including the top corners of the rectangular cross-section (Table C-1). Table C-1 contains a truncated list of blocks (sorted by impact energy) beginning with the rock block with the highest impact energy. A review of these data indicates that the blocks with the greatest impact energies impact the shoulders (i.e., the top corners of the rectangular cross-section) of the drip shield. The list of blocks in Table $\mathrm{C}-1$ has been truncated at a point coincident to the block with the highest impact energy that impacts center $1 / 3$ of the drip shield. For example:

- At $1.05 \mathrm{~m} / \mathrm{s}$ PGV level, the two blocks with the greatest impact energies of 87 and $84 \mathrm{~kJ}$ are shoulder impacts; the block with the third highest impact energy, $32 \mathrm{~kJ}$, contacts the top of the drip shield, toward the center.

- At $2.44 \mathrm{~m} / \mathrm{s}$ PGV level, the blocks with the seven greatest impact energies, ranging from 153 to $45 \mathrm{~kJ}$, are shoulder impacts. The block with the eighth greatest impact energy, $44 \mathrm{~kJ}$, contacts the top of the drip shield, toward the center. 
- At $5.35 \mathrm{~m} / \mathrm{s}$ PGV level, the blocks with the twenty-four greatest impact energies, ranging from 707 to $48 \mathrm{~kJ}$, are shoulder impacts. The block with the twenty-fifth greatest impact energy, $48 \mathrm{~kJ}$, contacts the top of the drip shield, toward the center.

Blocks that impact the shoulders of the drip shield are likely to form a crease where the slope of the drip shield is large. The creases are expected to allow seepage to run down the side of the drip shield, rather than retaining a "pool" of liquid in the dent. The blocks impacting the center $1 / 3$ of the drip shield (Figure C-1) could form dents that can pool water (since the slope of the drip shield increases away from the crown). 
Table C-1. Selection of Blocks with Highest Impact Energy That Could Dent Drip Shield Crown Area

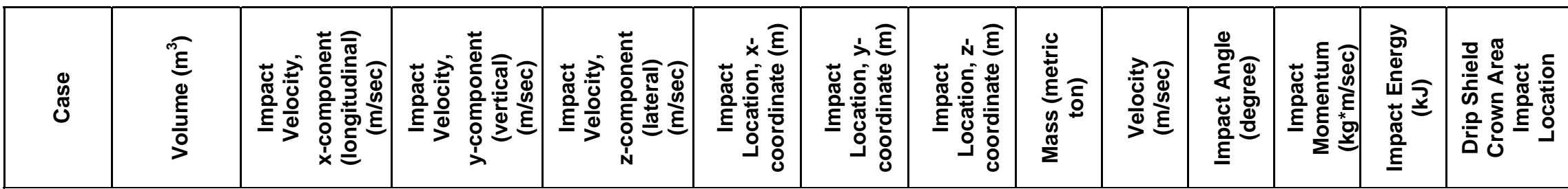

Impact information: $1 \times 10^{-4}$ Annual Exceedance Frequency - No blocks of sufficient enerav (i.e., areater than approximately $20 \mathrm{~kJ}$ ) were simulated.

Impact information: $1 \times 10^{-5}$ Annual Exceedance Frequency. PGV $=1.05 \mathrm{~m} / \mathrm{s}$ (BSC 2004 [DIRS 170027], Table 6.3-14). Total simulated drift lenqth $=1250 \mathrm{~m}$. \begin{tabular}{|c|c|c|c|c|c|c|c|c|c|c|c|c|c|c|}
\hline 40 & $3.11 \mathrm{E}+00$ & $4.00 \mathrm{E}-02$ & $-4.77 \mathrm{E}+00$ & $5.74 \mathrm{E}-01$ & $-6.63 \mathrm{E}+00$ & $1.44 \mathrm{E}+00$ & $-1.27 \mathrm{E}+00$ & 7.49 & 4.81 & 131 & 36017 & 87 & shoulder \\
\hline 53 & $3.03 \mathrm{E}+00$ & $4.20 \mathrm{E}-01$ & $-4.74 \mathrm{E}+00$ & $-5.22 \mathrm{E}-01$ & $3.52 \mathrm{E}+00$ & $1.44 \mathrm{E}+00$ & $-1.27 \mathrm{E}+00$ & 7.31 & 4.78 & 131 & 34967 & 84 & shoulder \\
\hline 40 & $5.57 \mathrm{E}-01$ & $3.83 \mathrm{E}-01$ & $-6.86 \mathrm{E}+00$ & $2.51 \mathrm{E}-01$ & $-6.52 \mathrm{E}+00$ & $1.44 \mathrm{E}+00$ & $3.17 \mathrm{E}-01$ & 1.34 & 6.87 & 78 & 9224 & 32 & center $1 / 3$ \\
\hline
\end{tabular} Impact information: $1 \times 10^{-6}$ Annual Exceedance Frequencv. PGV $=2.44 \mathrm{~m} / \mathrm{s}$ (BSC 2004 IDIRS 170027l. Table 6.3-16). Total simulated drift lenath $=1250 \mathrm{~m}$.

\begin{tabular}{|c|c|c|c|c|c|c|c|c|c|c|c|c|c|}
\hline 61 & $4.92 \mathrm{E}+00$ & $-1.34 \mathrm{E}+00$ & $-3.98 \mathrm{E}+00$ & $2.85 \mathrm{E}+00$ & $4.64 \mathrm{E}+00$ & $1.44 E+00$ & $-1.27 \mathrm{E}+00$ & 11.87 & 5.07 & 131 & 60231 & 153 & shoulder \\
\hline 40 & $5.50 \mathrm{E}+00$ & $5.13 \mathrm{E}-01$ & $-4.17 \mathrm{E}+00$ & $6.21 \mathrm{E}-01$ & $-7.26 \mathrm{E}+00$ & $1.44 \mathrm{E}+00$ & $-1.26 \mathrm{E}+00$ & 13.28 & 4.24 & 131 & 56344 & 120 & shoulder \\
\hline 67 & 4.45E-01 & $-5.54 \mathrm{E}+00$ & $-6.01 \mathrm{E}+00$ & $8.83 \mathrm{E}+00$ & $3.28 \mathrm{E}+00$ & $1.44 \mathrm{E}+00$ & $-1.27 \mathrm{E}+00$ & 1.07 & 12.03 & 131 & 12909 & 78 & shoulder \\
\hline 40 & $2.85 \mathrm{E}+00$ & $-1.17 \mathrm{E}+00$ & $-3.80 E+00$ & 4.32E-01 & $-5.60 E+00$ & $1.44 \mathrm{E}+00$ & $1.27 \mathrm{E}+00$ & 6.86 & 4.00 & 49 & 27469 & 55 & shoulder \\
\hline 33 & $4.77 \mathrm{E}+00$ & 4.30E-01 & $-2.89 \mathrm{E}+00$ & $-5.72 \mathrm{E}-01$ & $-3.98 E+00$ & $1.44 \mathrm{E}+00$ & $1.27 \mathrm{E}+00$ & 11.50 & 2.98 & 49 & 34257 & 51 & shoulder \\
\hline 64 & $1.40 \mathrm{E}+00$ & $1.41 \mathrm{E}+00$ & $-5.05 E+00$ & $1.25 \mathrm{E}+00$ & $5.45 \mathrm{E}+00$ & $1.44 E+00$ & $-1.25 \mathrm{E}+00$ & 3.36 & 5.39 & 131 & 18147 & 49 & shoulder \\
\hline 32 & $1.67 \mathrm{E}+00$ & $-2.68 \mathrm{E}+00$ & $-3.85 \mathrm{E}+00$ & 7.72E-01 & $8.62 \mathrm{E}+00$ & $1.44 E+00$ & $-1.27 \mathrm{E}+00$ & 4.02 & 4.76 & 131 & 19125 & 45 & shoulder \\
\hline 39 & $1.34 \mathrm{E}+00$ & $-1.70 \mathrm{E}+00$ & $-4.94 \mathrm{E}+00$ & 3.77E-01 & $-8.55 E+00$ & $1.44 E+00$ & 2.82E-01 & 3.23 & 5.23 & 79 & 16882 & 44 & center $1 / 3$ \\
\hline \multicolumn{14}{|c|}{ Impact information: $1 \times 10^{-7}$ Annual Exceedance Frequencv. PGV $=5.35 \mathrm{~m} / \mathrm{s}$ (BSC 2004 [DIRS 170027], Table 6.3-18). Total simulated drift lenath $=1100 \mathrm{~m}$. } \\
\hline 42 & 1.17E+01 & $-5.68 \mathrm{E}-01$ & $-6.76 \mathrm{E}+00$ & $1.98 \mathrm{E}+00$ & $2.75 \mathrm{E}+00$ & $1.44 \mathrm{E}+00$ & $-1.27 \mathrm{E}+00$ & 28.29 & 7.07 & 131 & 199979 & 707 & shoulder \\
\hline 42 & $6.15 \mathrm{E}+00$ & $-3.58 \mathrm{E}+00$ & $-5.76 \mathrm{E}+00$ & $1.25 \mathrm{E}+00$ & $-2.28 \mathrm{E}+00$ & $1.44 \mathrm{E}+00$ & $-1.27 \mathrm{E}+00$ & 14.82 & 6.90 & 131 & 102216 & 353 & shoulder \\
\hline 60 & $4.55 \mathrm{E}+00$ & $-1.42 \mathrm{E}+00$ & $-3.23 E+00$ & $4.91 \mathrm{E}+00$ & $-3.22 \mathrm{E}+00$ & $1.44 \mathrm{E}+00$ & $-1.27 \mathrm{E}+00$ & 10.98 & 6.04 & 131 & 66346 & 200 & shoulder \\
\hline 67 & $1.71 \mathrm{E}+00$ & $-1.00 E+00$ & $-7.39 \mathrm{E}+00$ & 3.95E-01 & $4.58 \mathrm{E}+00$ & $1.44 \mathrm{E}+00$ & $1.27 \mathrm{E}+00$ & 4.12 & 7.47 & 49 & 30789 & 115 & shoulder \\
\hline 44 & 3.99E-01 & $-6.46 \mathrm{E}+00$ & $-6.78 \mathrm{E}+00$ & $1.23 \mathrm{E}+01$ & $-1.96 \mathrm{E}+00$ & $1.44 \mathrm{E}+00$ & $6.58 \mathrm{E}-01$ & 0.96 & 15.46 & 66 & 14874 & 115 & shoulder \\
\hline 53 & $2.48 \mathrm{E}+00$ & $-3.43 E-02$ & $-5.94 E+00$ & $1.60 \mathrm{E}+00$ & $3.36 \mathrm{E}+00$ & $1.44 E+00$ & $-9.06 \mathrm{E}-01$ & 5.98 & 6.15 & 122 & 36791 & 113 & shoulder \\
\hline 61 & $4.92 \mathrm{E}+00$ & $-1.88 \mathrm{E}+00$ & $-3.59 E+00$ & 8.99E-01 & $2.96 \mathrm{E}+00$ & $1.44 \mathrm{E}+00$ & $-1.27 \mathrm{E}+00$ & 11.86 & 4.16 & 131 & 49300 & 102 & shoulder \\
\hline 53 & $7.10 \mathrm{E}+00$ & $-7.50 \mathrm{E}-01$ & $-2.95 \mathrm{E}+00$ & $-1.46 \mathrm{E}+00$ & $3.42 \mathrm{E}+00$ & $1.44 \mathrm{E}+00$ & $-1.08 E+00$ & 17.11 & 3.37 & 127 & 57713 & 97 & shoulder \\
\hline 15 & $1.81 \mathrm{E}+00$ & $-3.46 \mathrm{E}+00$ & $-3.52 E+00$ & $3.54 \mathrm{E}+00$ & $-7.87 \mathrm{E}+00$ & $1.44 \mathrm{E}+00$ & $-1.23 E+00$ & 4.35 & 6.07 & 131 & 26432 & 80 & shoulder \\
\hline 53 & $9.81 \mathrm{E}-01$ & $4.45 \mathrm{E}+00$ & $-5.63 E+00$ & $-3.59 \mathrm{E}+00$ & $8.30 \mathrm{E}+00$ & $1.44 \mathrm{E}+00$ & 8.57E-01 & 2.36 & 8.02 & 59 & 18970 & 76 & shoulder \\
\hline 33 & $4.77 \mathrm{E}+00$ & $-1.02 \mathrm{E}+00$ & $-2.98 \mathrm{E}+00$ & $-1.76 \mathrm{E}+00$ & $-5.60 \mathrm{E}+00$ & $1.44 \mathrm{E}+00$ & $1.27 \mathrm{E}+00$ & 11.49 & 3.61 & 49 & 41434 & 75 & shoulder \\
\hline \multirow{3}{*}{ (َ) } & 8.67E-01 & $3.55 \mathrm{E}+00$ & $-7.28 \mathrm{E}+00$ & $1.98 \mathrm{E}+00$ & $-4.79 \mathrm{E}+00$ & $1.44 \mathrm{E}+00$ & $-1.26 \mathrm{E}+00$ & 2.09 & 8.34 & 131 & 17427 & 73 & shoulder \\
\hline & $2.82 \mathrm{E}+00$ & $-2.94 \mathrm{E}-02$ & $-4.32 \mathrm{E}+00$ & $-7.30 \mathrm{E}-01$ & $-3.43 E+00$ & $1.44 \mathrm{E}+00$ & $1.27 \mathrm{E}+00$ & 6.79 & 4.38 & 49 & 29725 & 65 & shoulder \\
\hline & $4.40 \mathrm{E}+00$ & $1.53 \mathrm{E}+00$ & $-1.85 E+00$ & $-2.44 E+00$ & $-3.49 E+00$ & $1.44 \mathrm{E}+00$ & $1.26 \mathrm{E}+00$ & 10.60 & 3.43 & 49 & 36318 & 62 & shoulder \\
\hline
\end{tabular}


Table C-1. Selection of Blocks with Highest Impact Energy That Could Dent Drip Shield Crown Area (Continued)

\begin{tabular}{|c|c|c|c|c|c|c|c|c|c|c|c|c|c|}
\hline 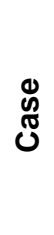 & 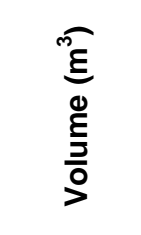 & 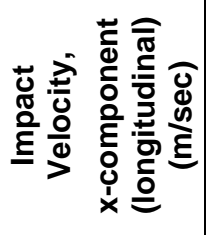 & 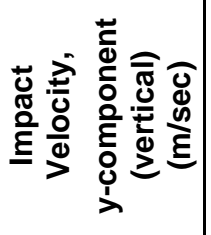 & 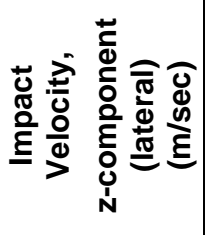 & 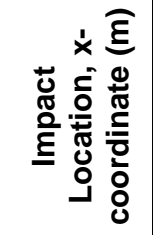 & 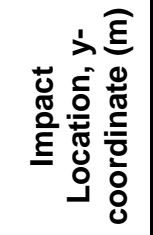 & 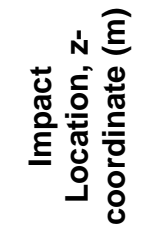 & 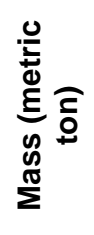 & 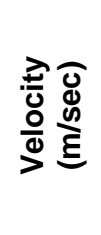 & 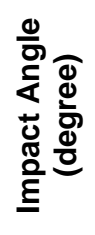 & 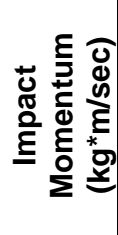 & 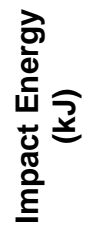 & 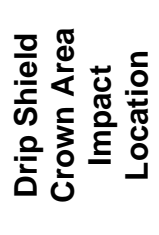 \\
\hline 17 & $1.23 \mathrm{E}+00$ & $1.36 \mathrm{E}+00$ & $-5.99 E+00$ & 2.12E-01 & $1.04 \mathrm{E}+01$ & $1.44 \mathrm{E}+00$ & $-1.27 E+00$ & 2.98 & 6.15 & 131 & 18291 & 56 & shoulder \\
\hline 49 & $1.28 \mathrm{E}+00$ & $3.10 \mathrm{E}+00$ & $-1.92 E+00$ & $4.53 \mathrm{E}+00$ & $3.02 \mathrm{E}+00$ & $1.44 \mathrm{E}+00$ & $-1.24 \mathrm{E}+00$ & 3.08 & 5.82 & 131 & 17955 & 52 & shoulder \\
\hline 48 & $1.38 \mathrm{E}+00$ & $-1.17 \mathrm{E}+00$ & $-5.24 \mathrm{E}+00$ & $-1.54 \mathrm{E}+00$ & $6.90 \mathrm{E}+00$ & $1.44 \mathrm{E}+00$ & 1.17E+00 & 3.31 & 5.58 & 51 & 18504 & 52 & shoulder \\
\hline 67 & $8.68 \mathrm{E}-01$ & $7.28 \mathrm{E}-01$ & $-6.90 E+00$ & $-9.69 \mathrm{E}-01$ & $1.59 \mathrm{E}+00$ & $1.44 \mathrm{E}+00$ & $-7.50 \mathrm{E}-01$ & 2.09 & 7.00 & 118 & 14653 & 51 & shoulder \\
\hline 27 & 8.09E-01 & $-3.96 \mathrm{E}+00$ & $-5.96 \mathrm{E}+00$ & $6.60 \mathrm{E}-01$ & $-5.01 E+00$ & $1.44 \mathrm{E}+00$ & $1.27 \mathrm{E}+00$ & 1.95 & 7.19 & 49 & 14010 & 50 & shoulder \\
\hline 64 & $1.53 \mathrm{E}+00$ & 7.61E-01 & $-5.01 \mathrm{E}+00$ & $-1.04 \mathrm{E}+00$ & $5.68 \mathrm{E}+00$ & $1.44 \mathrm{E}+00$ & $1.16 \mathrm{E}+00$ & 3.68 & 5.18 & 51 & 19037 & 49 & shoulder \\
\hline 29 & 2.26E-01 & $-8.87 E+00$ & $-6.95 E+00$ & $7.06 \mathrm{E}+00$ & $-8.89 E+00$ & $1.44 \mathrm{E}+00$ & $-4.59 \mathrm{E}-01$ & 0.54 & 13.30 & 108 & 7243 & 48 & shoulder \\
\hline 27 & 7.69E-01 & $-3.96 \mathrm{E}+00$ & $-5.98 E+00$ & $5.30 \mathrm{E}-01$ & $-5.00 E+00$ & $1.44 \mathrm{E}+00$ & $1.23 \mathrm{E}+00$ & 1.85 & 7.19 & 50 & 13327 & 48 & shoulder \\
\hline 58 & $2.09 \mathrm{E}+00$ & $2.59 \mathrm{E}+00$ & $-2.59 E+00$ & $-2.36 \mathrm{E}+00$ & $-4.52 \mathrm{E}+00$ & $1.44 \mathrm{E}+00$ & $1.27 \mathrm{E}+00$ & 5.04 & 4.35 & 49 & 21930 & 48 & shoulder \\
\hline 55 & $3.99 \mathrm{E}-01$ & $-5.66 \mathrm{E}+00$ & $-4.02 E+00$ & $7.13 \mathrm{E}+00$ & $6.17 \mathrm{E}+00$ & $1.44 \mathrm{E}+00$ & $-1.27 \mathrm{E}+00$ & 0.96 & 9.96 & 131 & 9581 & 48 & shoulder \\
\hline 66 & 4.19E-01 & $E+00$ & $E+00$ & $4.94 \mathrm{E}+00$ & $-1.16 \mathrm{E}+00$ & $1.44 \mathrm{E}+00$ & $-6.29 \mathrm{E}-02$ & 1.01 & 70 & 93 & 9796 & 48 & center $1 /$ \\
\hline
\end{tabular}

Source: DTN: MO0408MWDDDMIO.002 [DIRS 171483].

NOTES: The following steps are used to download data from the source DTN: (1) Select 'Download files.' (2) Copy the segmented zip file (10 files total) into a folder with approximately $140 \mathrm{~GB}$ of available space (the download requires $45 \mathrm{~GB}$ on one drive and the extraction requires $95 \mathrm{~GB}$ on that drive or another drive. If sufficient disk space is not available, contact the Model Warehouse Data Administrator using the link provided within the DTN). (3) select the file, "MO0408MWDDDMIO_002RPC1.zip," to extract the data from the DTN (note that WinZip version 9.0 or higher must be used to extract the compressed files; select 'Use folder names' from the WinZip 'Extract' dialog box). Source data are provided by the following Excel spreadsheets within the extracted data from the source DTN (the files are located in the folder, 'Calculation Filesl3DEC rockfall results'):

- nonlith rockfall characteristics in emplacement drifts with 1 e-4 gm.xls

- nonlith rockfall characteristics in emplacement drifts with 1e-5 gm.xls

- nonlith rockfall characteristics in emplacement drifts with 1e-6 gm.xls

- nonlith rockfall characteristics in emplacement drifts with 1 e-7 gm.xls.

The data in this table are provided in the worksheet, "Impact Information," located within each of the Excel spreadsheets listed above. This table contains a truncated list of blocks (sorted by impact energy) beginning with the rock block with the highest impact energy. The list of blocks has been truncated to show the block with the highest impact energy that impacts center $1 / 3$ of the drip shield. Note that the drip shield has been represented by a simplified rectangular geometry. Only those rockfalls impacting the top of the simplified rectangular drip shield have been included. The coordinate system and impact angle are illustrated in Figure C-2. Based on the local coordinate system used (see Figure C-2), the rock blocks impacting the crown of the drip shield will have a y-coordinate (column ' $y$-imp' in the Excel file) of $1.44 \mathrm{~m}$. The center one-third of the crown is in the range of z-coordinate (column 'z-imp' in the Excel file) of -0.426 to 0.426 


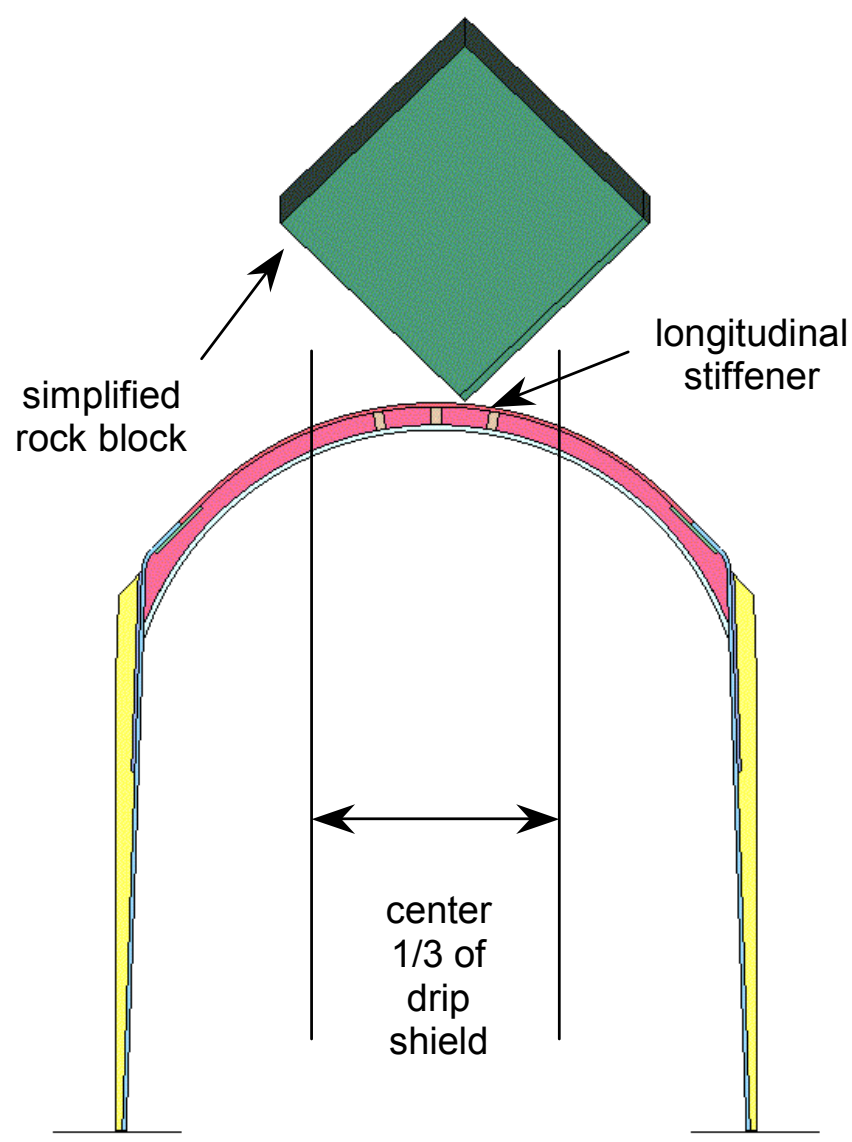

Source: BSC 2005 [DIRS 174052], Figure 6-3.

Figure C-1. Section View of Drip Shield 

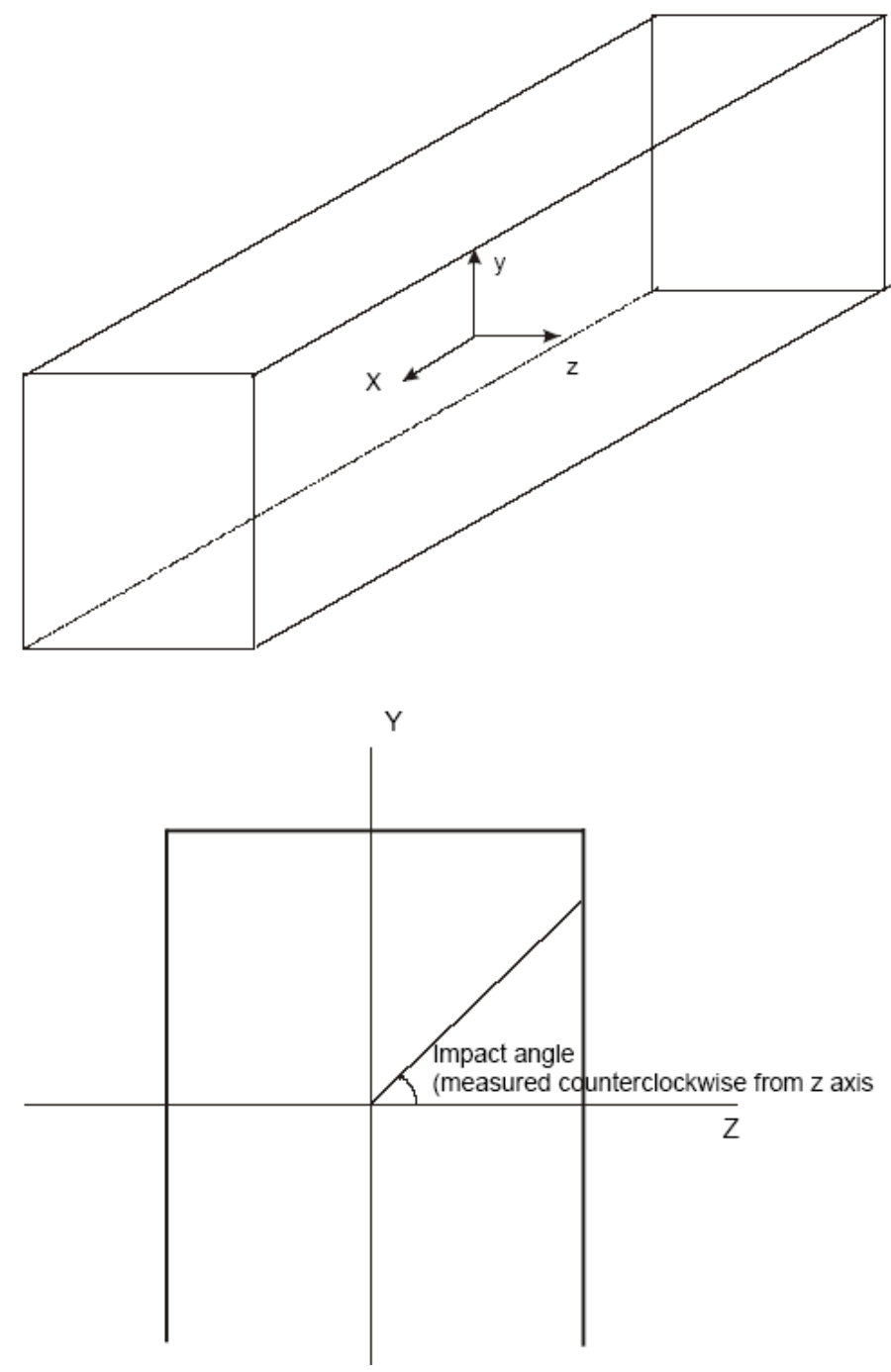

Source: BSC 2004 [DIRS 166107], Figure 6-42.

Figure C-2. Definition of Impact Angle and Drip Shield Block Local Coordinate System

\section{C.2.2 Structural Response of the Drip Shield to Individual Rock Blocks}

The structural response of the drip shield to impacts by individual rock blocks has been calculated with LS-DYNA using a three-dimensional representation of the drip shield as discussed in Drip Shield Structural Response to Rock Fall Supplemental Calculation (BSC 2005 [DIRS 174052]). The individual rock blocks are idealized as cubic in shape with two possible orientations: an edge-on impact to the crown of the drip shield and a corner-on impact to the crown of the drip shield. The edge-on impact has the edge perpendicular to the longitudinal axis of the drip shield. The corner-on impact has the corner impacting between the longitudinal stiffeners that support the crown of the drip shield. In either case, the center of mass is conservatively located directly over the impact point. 
The impact energy of the individual rock blocks has been selected to span the range of impact energies that are expected to result in a significant dent on the crown of the drip shield. The six individual cases are as follows (BSC 2005 [DIRS 174052], Section 3.2.2):

- A 880 Joule/0.28 MT block that corresponds to the 50th percentile of impact energy for the $2.44 \mathrm{~m} / \mathrm{s}$ PGV level $\left(1 \times 10^{-6}\right.$ annual exceedance frequency $)$

- A 2,569 Joule/0.69 MT block that corresponds to the 75th percentile of impact energy for the $2.44 \mathrm{~m} / \mathrm{s}$ PGV level $\left(1 \times 10^{-6}\right.$ annual exceedance frequency $)$

- A 12,894 Joule/0.96 MT block that corresponds to the 95th percentile of impact energy for the $2.44 \mathrm{~m} / \mathrm{s}$ PGV level $\left(1 \times 10^{-6}\right.$ annual exceedance frequency $)$

- A 86,559 Joule/7.49 MT block that corresponds to the maximum impact energy for the $1.05 \mathrm{~m} / \mathrm{s} \mathrm{PGV}$ level $\left(1 \times 10^{-5}\right.$ annual exceedance frequency $)$

- A 152,775 Joule/11.87 MT block that corresponds to the maximum impact energy for the $2.44 \mathrm{~m} / \mathrm{s}$ PGV level $\left(1 \times 10^{-6}\right.$ annual exceedance frequency $)$

- A 706,914 Joule 28.29 MT block that corresponds to the maximum impact energy for the $5.35 \mathrm{~m} / \mathrm{s}$ PGV level $\left(1 \times 10^{-7}\right.$ annual exceedance frequency).

The computational results for the edge-on impacts are summarized in Table C-2. Based on the results in Table C-2, the 152,775-Joule impact corresponds to the maximum rock block impact energy at the $2.44 \mathrm{~m} / \mathrm{s}$ PGV level. This did not result in a dent that would retain water. It follows then that only edge-on impacts with energies greater than 152,775 Joules could result in a dent that could catch or retain a seepage. The computational results for the corner-on impacts are presented in Drip Shield Structural Response to Rock Fall Supplemental Calculation (BSC 2005 [DIRS 174052], Figure 7-21 to 7-25).

A corner-on impact, between the longitudinal stiffeners, results in significant denting to the drip shield plates at lower impact energies than for the edge-on impacts in Table C-2. However, this corner-on geometry is considered extremely unlikely, particularly for blocks that are 1 metric ton or larger. As represented in the drip shield structural response calculation (BSC 2005 [DIRS 174052], Section 6.3), those blocks with corner impacts are assumed to have a resultant centroid velocity vector that is directly in line with the impacting block corner (Figure C-1). In other words, all of the force of the accelerated block is assumed to be concentrated directly through the block corner. This assumption is highly improbable as the model predictions of rockfall (BSC 2004 [DIRS 166107], Section 6.3) show that blocks have complex, irregular geometries (BSC 2004 [DIRS 166107], Appendix I), and that the applied complex earthquake vibratory motion results in blocks that rotate as they fall (BSC 2004 [DIRS 166107], Figure 6-38). The blocks then impact the curving drip shield crown with glancing impacts that have not only normal, but also tangential force components. Thus, the assumed corner impacts are considered to be an extreme case and highly unlikely. Additionally, contacts of a rock block corner to the stiff drip shield structure will result in shearing or fragmentation and disintegration of the contact point which will consume some of the block kinetic energy. This fragmentation potential was not accounted for in the analysis of denting (BSC 2005 [DIRS 174052], 
Section 6.5). The result of fragmentation is that, in reality, contact forces and energies would be far smaller than represented in the corner impact analyses. The results for the corner-on impacts have therefore been excluded from further consideration in this argument.

Table C-2. Results for Edge-On Impacts

\begin{tabular}{|l|l|l|}
\hline \multicolumn{1}{|c|}{$\begin{array}{c}\text { Impact Energy } \\
\text { (Block Mass) }\end{array}$} & \multicolumn{1}{|c|}{$\begin{array}{c}\text { Source in } \\
\text { [DIRS 174052] }\end{array}$} & Structural Response \\
\hline 880 Joule $(0.28 \mathrm{MT})$ & Figure 7-14 & No measurable dent-seepage will run off. \\
\hline 2,569 Joule (0.69 MT) & Figure 7-15 & No significant deformation-seepage will run off \\
\hline 12,894 Joule (0.96 MT) & Figure 7-16 & $\begin{array}{l}\text { Small deformation, but the slope within the dent allows seepage to } \\
\text { run off }\end{array}$ \\
\hline 86,559 Joule (7.49 MT) & Figure 7-17 & $\begin{array}{l}\text { Significant dent, but the remaining slope within the dent allows } \\
\text { seepage to run off }\end{array}$ \\
\hline 152,775 Joule (11.87 MT) & Figure 7-18 & $\begin{array}{l}\text { Significant dent, with a small flat at the top of the crown but no } \\
\text { depression. Droplets of seepage may remain on the flat, but } \\
\text { should runoff before forming a "pool" with significant depth. }\end{array}$ \\
\hline 706,914 Joule (28.29 MT) & Figure 7-19 & $\begin{array}{l}\text { Significant denting, with a small depression between the } \\
\text { longitudinal stiffeners. Seepage can pool in this dent. The dent is } \\
63.5-m m \text { long in the axial direction. The volume of the small } \\
\text { depression is about 5.35 } \times 10^{-5} \mathrm{~m}^{3} \text { or } 1.8 \text { ounces. }\end{array}$ \\
\hline
\end{tabular}

Source: BSC 2005 [DIRS 174052], Section 7.

\section{C.2.3 Bounded Hazard Curve for Peak Ground Velocity}

There are no blocks at the $1.05 \mathrm{~m} / \mathrm{s}$ and $2.44 \mathrm{~m} / \mathrm{s}$ PGV levels that cause a significant dent to form on the drip shield. The probability that seismic events with PGV levels greater than $2.44 \mathrm{~m} / \mathrm{s}$ will occur can be calculated from the hazard curve for PGV. A hazard curve defines the annual frequency of seismic events that exceed a given intensity level. Intensity is often measured in peak ground acceleration or peak ground velocity. For the seismic scenario class in TSPA, intensity is being measured by horizontal peak ground velocity (PGV). The bounded hazard curve for PGV indicates that the annual exceedance frequency for all seismic events with PGV greater than $2.44 \mathrm{~m} / \mathrm{s}$ is $4.52 \times 10^{-7}$ per year (DTN: MO0501BPVELEMP.001 [DIRS 172682]).

This exceedance frequency includes very unlikely seismic events, including those with exceedance frequencies less that $10^{-8}$ per year. However, the performance assessment for the repository must consider only those events with a probability greater than 1 in 10,000 over a 10,000 year period (10 CFR 63.114 [DIRS 173273]), corresponding to events with an annual probability ${ }^{1}$ greater than $10^{-8}$. It follows that the very unlikely seismic events can be excluded from this probability analysis. These very unlikely events can be eliminated from consideration

${ }^{1}$ The exceedance frequency from the hazard curve and the exceedance probability are essentially equal for very low frequency events. The probability of one or more events for a random (Poisson) process with annual rate $\lambda$ over duration $T$ is given by $\left(1-\mathrm{e}^{-\lambda T}\right)$. When $\lambda$ is small enough, the probability that one or more events occur in an interval $T$ becomes $\left(1-\mathrm{e}^{-\lambda T}\right)=1-$ $\left(1-\lambda T+(\lambda T)^{2}-\ldots\right) \approx \lambda T$. The annual probability for one or more events is then given by $(\lambda T) / T=\lambda$, the annual frequency of events. A typical criterion for the accuracy of this expansion is that $\lambda T \leq 0.1$. This criterion is satisfied for this analysis because $\lambda=4.4 \times 10^{-7}$ per year and $T=10,000$ years, so that $\lambda T=4.4 \times 10^{-3}$. 
by subtracting the exceedance frequency for the very unlikely events from that for all the events with PGV greater than $2.44 \mathrm{~m} / \mathrm{s}$ :

$$
\text { Final Frequency }=4.52 \times 10^{-7} \text { per year }-10^{-8} \text { per year }=4.42 \times 10^{-7} \text { per year } \quad \text { (Eq. C-1) }
$$

The annual probability of seismic events that can cause a significant dent to form in the drip shield is then $4.42 \times 10^{-7}$ per year, and the corresponding probability over 10,000 years is given by:

$$
\text { Probability Over 10,000 Years }=\left(4.42 \times 10^{-7} \text { per year }\right)(10,000 \text { years })=4.42 \times 10^{-3} \sim 0.004
$$

This probability (alone) cannot be used to screen denting of the drip shield out of TSPA because it exceeds 1 chance in 10,000. However, the significant conservatisms in the probability calculation are considered next.

\section{C.2.4 Conservatisms in Probability Analysis}

The probability analysis for denting from rockfall induced by seismic events has a number of conservative assumptions:

- A large rock block is a partly fractured structure that is likely to crumble or partly shatter on impact with the drip shield. However, the potential for block failure is not included in the structural response calculations.

- Smaller rock blocks that partly shelter the drip shield from direct impact often precede large rock blocks. The potential for rubble to distribute the impact loads is not included in the structural response calculations.

- The orientation and shape of rock blocks is conservatively chosen to maximize damage by locating the center of mass directly above the impact point. Blocks have a cubic shape for the LS-DYNA calculations, with the center of mass directly above an edge that contacts the crown of the drip shield. Based on the rockfall calculations, impacts by the highest energy blocks are likely to be mitigated by the tendency toward shoulder impacts rather than crown impacts and by the irregular block shape, wherein the center of mass is not directly over the impact point.

It should be noted that the ratio of the damaged area on the drip shield to the total drip shield area within the repository is very small. The largest dent capable of pooling water is $63.5 \mathrm{~mm}$ long (Table C-2) in the axial direction. Given the 25-m rockfall model domain (Section C.2.1), there is $0.0635-\mathrm{m}$ dent length per 25 meters of drip shield. Furthermore, $85 \%$ of the drip shields in the repository will not be subject to denting from rockfall since they will be located in lithophysal rocks (Section C.1). 